UNIVERSIDADE DE SÃO PAULO

FACULDADE DE FILOSOFIA, LETRAS E CIÊNCIAS HUMANAS DEPARTAMENTO DE TEORIA LITERÁRIA E LITERATURA COMPARADA PROGRAMA DE PÓS-GRADUAÇÃO EM TEORIA LITERÁRIA

E LITERATURA COMPARADA

\author{
JULIO AUGUSTO XAVIER GALHARTE
}

\title{
DESPALAVRAS DE EFEITO: OS SILÊNCIOS NA OBRA DE MANOEL DE BARROS
}

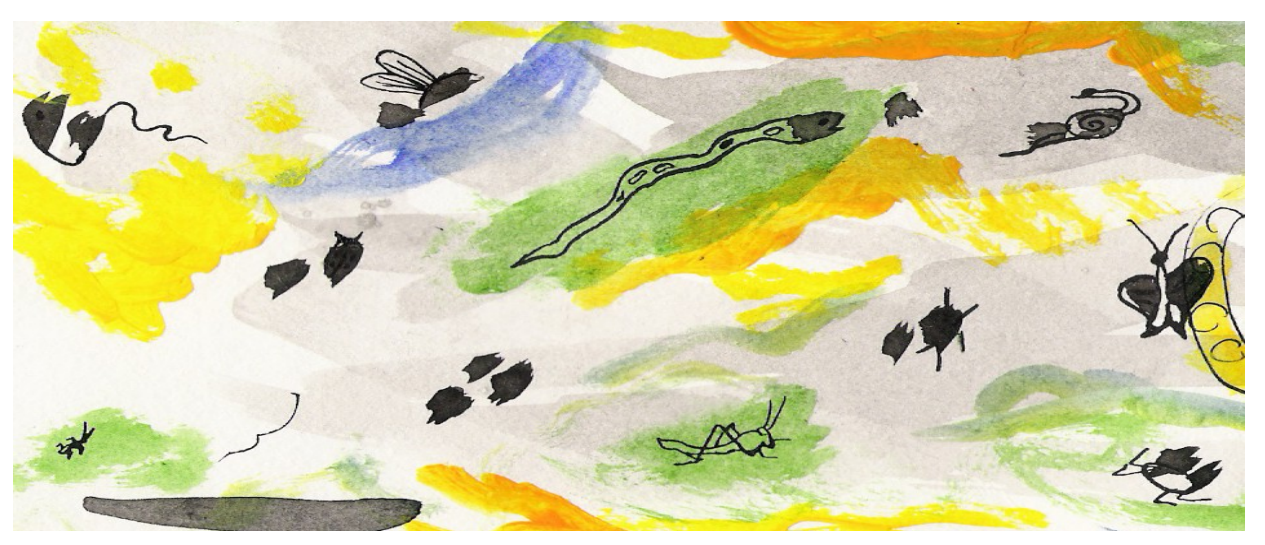

Bernardini.

Tese apresentada ao Programa de Pós-graduação em Teoria Literária e Literatura Comparada da Faculdade de Filosofia, Letras e Ciências Humanas, para a obtenção do título de Doutor.

Orientação: Prof ${ }^{a}$. Dra ${ }^{\mathrm{a}}$.Aurora Fornoni 
São Paulo

2007

Houve um poema,/ entre a alma e o universo./

Não há mais./Bebeu-o a noite, com seus lábios silenciosos/ com seus olhos estrelados de/ muitos sonos./ Houve um poema./ Parecia perfeito/ cada palavra em seu lugar,/ como as pétalas nas flores/ $e$ as tintas no arco-íris/ No centro, mensagem doce/ e intransmitida jamais./ Houve um poema:/ e era em mim que surgia, vagaroso./ Já não me lembro, e ainda me lembro./ As névoas da madrugada envolvem sua memória./ É uma tênue cinza./ O coral do horizonte é um rastro de sua cor./ [...] [Cecília Meireles, Metal rosicler] 
Uma formiguinha atravessa, em diagonal, a página ainda em branco. Mas ele, aquela noite, não escreveu nada. Para quê? Se por ali já havia passado o frêmito e o mistério da vida... [“O poema”, de Mário Quintana] 
Ao Manoel, por me fazer esbarrar na apoteose e no delírio da beleza.

\section{SUMÁRIO}

\section{INTRODUÇÃO-ITINERÁRIO OU NO COMEÇO E NO FIM ERA O SILÊNCIO 1}

CAPÍTULO 1 - A INARTICULABILIDADE POLISSÊMICA 6

"Ora, direis, ouvir" silêncios ...............................................................8

Mudez na mira ...............................................................................26

Leitores do guardador de águas e de calares ................................38

CAPÍTULO 2 - MUTISMOS EM MANOELÊS ................................50

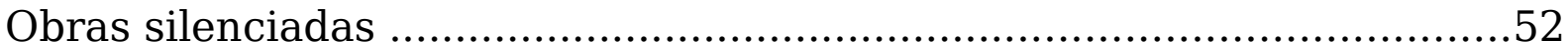

Compêndios e gramáticas do não falar..............................................64

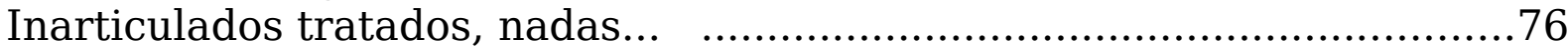

CAPÍTULO 3 - A DESPALAVRA PINTADA E FILMADA:

RETRATO DO ARTISTA QUANDO COISA (1998).....................89

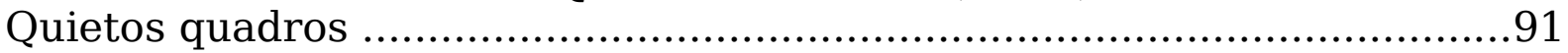

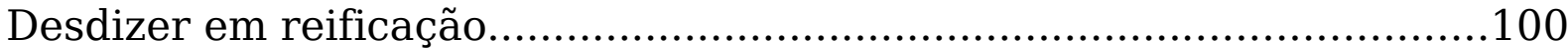

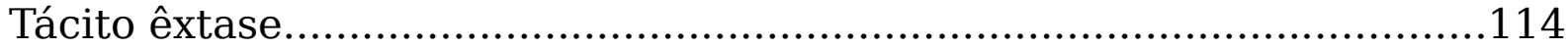

CAPÍTULO 4 - POLICROMÁtiCA E POLIFÔNICA PELÍCULA DA PRÉPALAVRA:

O LIVRO DAS IGNORÃÇAS (1993)...................................130

Audíveis imagens do não saber ..............................................132

Azulácea e amarela ante-palavra ..............................................139

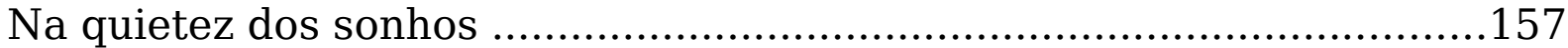

CAPÍTULO 5 - SILENTES INSETOS EM CENA:

ARRANJOS PARA ASSOBIO (1982).....................................175

Entre vespas e versos desverbados ............................................177

Patas, antenas e asas dos silêncios.................................................188

"A evidência não interessava" ..................................................200 


\section{REFERÊNCIAS}

BIBLIOGRÁFICAS.

FILMOGRAFIA

Serão usadas as seguintes siglas para identificar as obras de Manoel de Barros:

PCP - Poemas concebidos sem pecado;

FI - Face imóvel;

P - Poesias;

CUP - Compêndio para uso dos pássaros;

GEC - Gramática expositiva do chão;

MP - Matéria de poesia;

AA - Arranjos para assobio;

LPC - Livro de pré-coisas;

GA - O guardador de águas;

PQT-Gramática expositiva do chão: poesia quase toda;

CCASA - Concerto a céu aberto para solos de ave;

LI - O livro das ignorãças;

LN - Livro sobre nada;

RAQC - Retrato do artista quando coisa;

ESC - Exercícios de ser criança;

EF - Ensaios fotográficos;

FA - O fazedor de amanhecer;

TGGI - Tratado geral das grandezas do ínfimo;

PPFJ - Poeminhas pescados numa fala de João 
TS - 30 segundos;

CUPT - Cantigas por um passarinho à toa;

MII - Memórias inventadas - a infância;

PR - Poemas rupestres;

MISI - Memórias inventadas - a segunda infância. 


\title{
RESUMO
}

Esta pesquisa busca os significados dos silêncios na obra de Manoel de Barros. Eles são observados, basicamente, a partir dos sentidos da visão e da escuta. Os mutismos do autor são analisados dentro da palavra e fora dela: nas entrelinhas, nas relações com outros autores, como Anton Tchékhov, Clarice Lispector e Samuel Beckett, por exemplo. Diálogos entre os silêncios de Barros e dos cineastas Luis Buñuel, Akira Kurosawa e Federico Fellini são, também, observados.

Palavras chave:

Silêncios - Poesia - Cinema - Manoel de Barros - Literatura comparada

\begin{abstract}
This research seeks the meanings of the silences in the works of Manoel de Barros. They are observed, basically, from the senses of the vision and of the listening. The mutisms of the author are analysed inside the word and outside it: in the implied senses and in the relations with other writers, such as Anton Tchekhov and James Joyce, for example. Dialogues between the silences of Barros and of the filmmakers Luis Bunuel, Akira Kurosawa and Federico Fellini are observed too.
\end{abstract}

Key words: 
Silences - Poetry - Cinema - Manoel de Barros - Comparative Literature

\section{AGRADECIMENTOS}

Aos meus queridos pais e irmãos.

Ao Valentim dos Santos, pela doce e terna cumplicidade, pela leitura atenta deste texto e pelo desenho da sua capa.

À Daniela Kahn, Elena Vássina, Mariarosaria Fabris e ao Ricardo Iannace, pelas fundamentais contribuições para este estudo.

Ao André Cordeiro, por sensibilizar meu olhar para o pictórico.

Ao Julio Couto, pela leitura deste texto, com suas devidas sugestões nos âmbitos lingüísticos e filosóficos.

À orientadora Profa. Dra. Aurora Fornoni Bernardini, pelo convívio intelectual, por me incentivar a ler em italiano e por respeitar minhas interpretações dos textos de Manoel de Barros.

À importante bolsa CAPES. 


\title{
INTRODUÇÃO-ITINERÁRIO
}

\author{
OU \\ NO COMEÇO E NO FIM ERA O SILÊNCIO
}


Em um trecho de Concerto a céu aberto para solos de ave, de Manoel de Barros, lê-se: Quando eu nasci/ o silêncio foi aumentado./ Meu pai sempre entendeu/ Que eu era torto/ [...]./ Passei anos me procurando por lugares nenhuns./ Até que não me achei - e fui salvo./ [...] (CCASA - 16-17). Esse escrito manoelino dialoga com o "Poema de sete faces", de Carlos Drummond de Andrade, pois, além de começarem de forma parecida [Quando (eu) nasci...], o "eu" manoelino é tão torto quanto o anjo do texto drummondiano. No entanto, uma diferença desponta no nascimento dos dois sujeitos poéticos: ao invés do discurso (do anjo que diz: Vai, Carlos! ser gauche na vida do escrito do autor mineiro, tem-se a inarticulabilidade do poema do escritor cuiabano (o silêncio foi aumentado).

Certa vez, Drummond afirmou que Barros era o maior poeta vivo do Brasil. É bem possível que a força e a qualidade poéticas em Manoel, notadas por Carlos, devam-se em parte aos silêncios que há nos escritos do autor de Livro sobre nada, cujo nada, inclusive, é definido como um alarme para o silêncio. (LN $-7)$.

Os mutismos pululam não só nos já mencionados Concerto a céu aberto para solos de ave e Livro sobre nada, mas estão em toda a obra de Barros: em $O$ guardador de águas, Bernardo prende o silêncio com fivela (GA - 35) e sem mexer com a boca ele tira ardor de pétalas (GA - 35); na Gramática expositiva do chão, o homem de lata/ se faz um corte/ na boca/ para escorrer/ todo o silêncio dele (GEC - 27); em Poesias, lê-se: Ai, sossego de terras pisadas por mim.../ E os silêncios caídos como folhas/ Nos limites de uma tarde aberta... [P 85].

Por que tantas menções à ausência da palavra? Como o silêncio se apresenta ao longo das obras de Manoel de Barros? Para responder a essas perguntas, foram elaborados os quatro capítulos deste ensaio.

O primeiro, intitulado "A inarticulabilidade polissêmica", é composto por três seções: a primeira é "Ora, direis, ouvir silêncios", em que são mostrados vários discursos a respeito da inarticulabilidade ligada à escuta, provindos de escritores e estudiosos de diversos tempos e lugares. A segunda parte é “Mudez 
na mira", observando os silêncioss audientes e a terceira é "Leitores do guardador de águas e de calares", apresenta a fortuna crítica do poeta cuiabano.

O segundo capítulo é "Mutismos em manoelês", em que se tem um panorama da variedade de sentidos silentes na obra de Barros, tomando obra por obra em ordem cronológica, ou seja, todas as publicações do escritor, foram observadas, começando pelo livro inaugural, Poemas concebidos sem pecado, de 1937, até chegar a Poeminha em língua de brincar, de 2007.

No capítulo terceiro, o foco recai sobre os específicos mutismos de Retrato do artista quando coisa e, no quarto, a atenção volta-se para os silêncios de Arranjos para assobio. Analisa-se, primeiramente, o livro manoelino mais recente e depois parte-se para o mais antigo, contrariando a seqüência do segundo capítulo. Essa organização imita a proposta de Barros de adiantar-se para o início, pois a idéia aqui é mostrar que novos elementos silenciosos da poesia manoelina são marcados pela anterioridade. Assim, o terceiro capítulo é "A despalavra pintada e filmada: Retrato do artista quando coisa (1998)" e o quarto é "Silentes insetos em cena: Arranjos para assobio (1982)".

A erudição de Manoel de Barros acabou me incentivando, em um momento do Doutorado, a abandonar a idéia de estudar o silêncio em sua obra, para mostrar o retrato do artista quando (des)leitor. Essa pesquisa acabou acontecendo: estudei o diálogo manoelino com James Joyce, Nikolai Gógol, Katherine Mansfield, José de Alencar e outros.

Percebi, posteriormente, que era possível unir os dois temas, já que existe o silêncio da leitura, mencionado, inclusive, por Walter Benjamim no seu ensaio "O narrador". O pensador de Frankfurt mostra que se na Antiguidade e na Idade Média a arte de narrar estava associada à coletividade e à oralidade, já nos tempos do romance as narrativas são escritas solitária e silenciosamente para pessoas que solitária e silenciosamente as lêem. A escrita e a leitura modernas atestam, pois, a apoteose do isolamento e da mudez.

O escritor argentino Juan José Saer, em uma entrevista à Folha de São Paulo, realizada logo após o recebimento do Prêmio Roger Callois pelo conjunto da obra, juntamente com Haroldo de Campos, em 1999, comenta sobre a associação entre o silêncio e a leitura, mencionando, inclusive, Benjamin: Uma 
das coisas específicas da literatura é a leitura em silêncio e em solidão. Isso é muito importante, porque torna a literatura mais difícil de ser apropriada pelo meio industrial, o que não acontece, por exemplo, com a música, tornada música de fundo ou música ambiente, ou como a pintura, que serve cada vez mais à difusão publicitária - um processo que foi notado por Walter Benjamin já nos anos 30. (Saer, 1999, p. 5-5).

O silêncio da leitura está ligado não só à mudez do leitor mas também ao não-dito de certos autores que produzem textos que têm sua força no implícito, na sugestão, fazendo com que sejam não só lidos mas relidos.

Esse silêncio das entrelinhas ou da elipse é explicado pelo mesmo Saer, já citado:

há o que se silencia no texto, seja porque o escritor não se atreve a falar de algo, seja porque, silenciando, aquilo que é dito adquire uma espécie de ambigüidade e força interior. É como se as coisas que não são ditas, mas que estão subjacentes ao texto, lhe conferissem uma outra dimensão. Isso ocorre com muitos autores, alguns extremamente elípticos, que dizem menos do que queriam dizer e muitas vezes nem sequer sugerem. As coisas não ditas ficam então flutuando, porque o leitor percebe que foram silenciadas conscientemente. (Saer, 1999, p. 5-5).

Desses autores extremamente elípticos, elegi Samuel Beckett e Clarice Lispector, para comparar com Manoel, o que é feito, respectivamente nos capítulos terceiro e quinto. Assim, observam-se as relações da despalavra manoelina com a não palavra clariciana e a unword beckettiana. Um dos motivos dessa escolha foi que a autora brasileira, o escritor irlandês e seus muitos silêncios já haviam sido estudados no meu Mestrado, desenvolvido também junto ao Departamento de Teoria Literária e Literatura Comparada e defendido em 2000. Como Anton Tchékhov, já no século XIX, incentivava o leitor a mirar o que havia nas entrelinhas, antecipando as propostas de Beckett e Lispector, ele é contrastado com o poeta cuiabano no quarto capítulo.

Notei que a poética manoelina se interessava não só por autores afeitos ao silêncio da elipse, mas também por imagens de quadros modernos bem como 
paisagens do Pantanal. Todos esses elementos se enquadravam no mesmo contexto: o silêncio ligado à visão.

Por esse motivo, o leitor desta tese é convidado a mirar um retrato, mais especificamente o Retrato do artista quando coisa, no terceiro capítulo. Se o olhar busca não só as palavras, mas as lacunas dos livros, se o ver procura as formas da arte pictórica e se o mirar anseia por silentes pedras e quietos caramujos do pântano é preciso também pensar no canto sem palavras desse mesmo pântano e nos seus mais diversos ruídos. Assim, chega-se ao silêncio da escuta: emudece-se para não perder a beleza e os detalhes dos cantar, do falar e do silenciar da natureza e do homem pantaneiro.

O silêncio da escuta é comentado no livro Por uma fenomenologia do silêncio, que registra um encontro de pensadores na Universidade Federal do Rio de Janeiro para uma discussão sobre os sentidos filosóficos da inarticulabilidade. Hans Ruin, em "O silêncio da filosofia: sobre discurso e taciturnidade em Heidegger", mostra que o filósofo alemão, em seu Ser e tempo, apresenta o mutismo ligado ao "ouvir" e ao "guardar silêncio".

A audiente inarticulabilidade é explicada: Ouvir é abrir-se tanto para a voz do outro como para a voz que cada um carrega dentro de si. [Ruin, 1996, p. 19]. Com isso, o estudioso apresenta o contexto do próprio congresso para explicar esse conceito de Heidegger:

Em todo encontro filosófico, tal como aqui experimentamos, não há lugar apenas para palavras, mas também para o silêncio. Para começar, dou a vocês minhas palavras e vocês me dão o seu silêncio, $e$ quando vocês retornam para as suas palavras, eu lhes dou o meu silêncio. [Ruin, 1996, p. 15].

Barros, que é leitor de Heidegger, compartilha com ele a sabedoria que se adquire no quieto escutar, no entanto, diferentemente do comentador heideggeriano (Ruin), o poeta brasileiro, em um Congresso, emudeceria para ouvir os outros sem inverter essa posição. Manoel, quando convidado a encontros em sua homenagem, evita o falar, ele apenas se dedica única e exclusivamente ao silêncio da escuta.

A propósito, pude testemunhar uma dessas situações; ela ocorreu na cidade de Corumbá, num encontro que daria o nome do escritor à biblioteca da 
Universidade Federal de Mato Grosso do Sul. Convidado a falar, Manoel permaneceu como estava antes, quieto, cabendo à professora Rita Baltar dizer: a palavra do poeta é a sua poesia. Em seguida, houve leitura e dramatização dos escritos manoelinos feitos pela jornalista Lívia Galharte Gaertner, pelo ator Salim Haqzan e pelo músico Luciano Gibaile Arévolo.

Há, nessa tese, um comparação do escritor cuiabano com cineastas cineastas, já que os silêncios ligados ao ver e ao ouvir podem se conjugar na sétima arte: filmes suscitam o aguçar desses dois sentidos e podem ser grandes divulgadores de mutismos. Por isso, películas de Federico Fellini e de Luis Buñuel são contrastados com a poética manoelina, respectivamente nos capítulos terceiro e quarto.

O gosto manoelino pelo cinema foi mostrado por Eva Spitz, em "O poeta que poucos conhecem": Em Nova York, [Manoel de Barros] fez cursos sobre cinema e sobre pintura no Museu de Arte Moderna. Conta que passava os dias na cinemateca, ou sentado horas seguidas diante do mesmo quadro. [...]. Sua poesia já se alimentava então de imagens, de quadros e de filmes... os "poetas da imagem", como chamava. Seus cineastas preferidos são Federico Fellini ("transfigurador de tudo"), Akira Kurosawa, Luis Buñuel ("no qual as evidências não interessam”). (Spitz, apud: Castro, 1992, p. 58).

Tem poesia no cinema? Essa pergunta do jornalista José Geraldo Couto tem esta resposta de Manoel: Muita, muita. Esse aí que morreu, o Fellini, eu quase que chorei. Esse cara era um grande poeta. Buñuel, Antonioni, Visconti são poetas. Tem uns americanos também: o John Ford, o Carlitos. [Barros, in: Couto, 1993, p. 9].

Observemos, doravante, o verbo dos especialistas sobre a inarticulabilidade e atentemos para as despalavras que pululam nas obras do poeta, pois, o que afirma o sujeito poético de Concerto a céu aberto para solos de ave serve também para seu autor: Quando nasci o silêncio foi aumentado. Com certeza, Barros contribui muito para que se ampliem os sentidos do mutismo. 
1

A INARTICULABILIDADE POLISSÊMICA 
Largos Silêncios interpretativos, Adoçados por funda nostalgia, Balada de consolo e simpatia Que os sentimentos meus torna cativos;

Harmonia de doces lenitivos, Sombra, segredo, lágrima, harmonia Da alma serena, da alma fugidia Nos seus vagos espasmos sugestivos. 
Ó Silêncios! Ó cândidos desmaios, Vácuos fecundos de celestes raios De sonhos, no mais límpido cortejo...

Eu vos sinto os mistérios insondáveis, Como de estranhos anjos inefáveis O glorioso esplendor de um grande beijo! ("Silêncios", de Cruz e Sousa)

\section{ORA, DIREIS, OUVIR SILÊNCIOS ${ }^{1}$}

No princípio era o dó, e o dó fez-se ré, etc. [Machado de Assis. Dom Casmurro].

O que é o silêncio?

É melhor reelaborar a pergunta, questionando o que são os silêncios, pois, assim como na palavra, também na sua ausência podem habitar variadíssimas significações. Theodor Reik, em seu ensaio "No início é o silêncio", apresenta um rol de significados para o mutismo, afirmando que ele pode ser frio ou aprovador, opressor ou humilde, provocante ou apaziguador, implacável ou indulgente [Reik, 1989, p. 19].

Assim, os mutismos podem ter sentidos positivos ou negativos e, em várias passagens de Crime e castigo, de Fiódor Dostoievski, surgem alguns silêncios muito próximos aos listados por Reik, como o opressor, o provocante e o implacável.

Raskolnikov assassina as irmãs Aliena e Lisavieta, mantendo por muito tempo silêncio sobre seu ato, mas sua mãe desconfia que há algo de errado com o filho e o seu mutismo: Fez-se silêncio. Havia qualquer coisa de tenso em toda essa conversa, no silêncio, [...]. [Dostoiévski, 2002, p. 238].

Um dia o protagonista do romance vai até o local do crime: Eis também o terceiro andar; seguir ou não adiante? E que silêncio faz lá, dá

$\overline{1}$ O título desta seção foi inspirado no célebre verso de Olavo Bilac: Ora, direis, ouvir estrelas. 
até medo... [Dostoiévski, 2002, p. 286]. O chefe de instrução, Porfiri Pietróvitch, por causa de vários indícios, tem certeza de que o assassino é o estudante. Assim, o silêncio sombrio [Dostoiévski, 2002, p. 276] entremeia suas conversas, plenas de atritos.

Raskolnikov usa o mutismo como proteção e provocação:

De quando em quando lhe dava vontade de lançar-se sobre Porfiri e esganá-lo ali mesmo. [...]. Sentia os lábios ressecados, fisgadas no coração, espuma coagulada nos lábios. Mas ainda assim decidiu calar $e$ por ora não pronunciar uma só palavra. Compreendeu que essa era a melhor tática em sua situação, porque, além de não deixar escapar nada, ainda iria irritar com $o$ silêncio o próprio inimigo e, quem sabe, este ainda acabaria deixando escapar alguma coisa. [Dostoiévski, 2002, p. 351].

Um silêncio pesado [Dostoievski, 2002, p. 276], embalado por intensa antipatia, intromete-se entre o protagonista e Lújin, o noivo de sua irmã, Dúnia. Ela rompe o noivado e, ao final do livro, contrai núpcias com Razumíkhin; é um casamento triste e silencioso [Dostoiévski, 2002, p. 548], porque, nessa passagem, Raskolnikov está preso, passando dias a fio calado [Dostoiévski, 2002, p. 552].

No meio de tantos mutismos negativos, aparece um pleno de positividade: a inarticulabilidade amorosa, pois Sonia sempre visita seu amado e, diante do lúgubre mutismo dele, ela também se cala, mas sempre calorosa, enchendo-o de cuidados.

Em uma passagem do seu Diário_Soren Kierkegaard afirma: $O$ amor gosta do silêncio [apud: Kovadloff, 2003, p. 173]. O ensaísta Santiago Kovadloff amplia a discussão: A autêntica eloqüência do silêncio amoroso se desdobra fora da consciência subjetiva, no seio da gestualidade corporal; na carícia lenta que traça seu itinerário, no fervor de um beijo, no arrebatamento de um abraço, na vertigem da penetração, na ascenção do gozo e na esmagadora dissolução do orgasmo. [Kovadloff, 2003, p. 163-164].

O emudecimento de cunho íntimo é estudado por Marisa Simons, em 
seu livro As falas do silêncio em O fiel e a pedra de Osman Lins. Ela observa que se o silêncio aparta Júlia e Augusto do conto "Cadeira de balanço", do autor pernambucano, já Bernardo e Teresa, do seu segundo romance, $O$ fiel e a pedra, nos momentos de amor, calam-se prazerosos, entendendo o quão inútil é o verbo já que valorizam, nesses e em outros momentos, a comunicação dos gestos e não das palavras.

Em Um copo de cólera, de Raduan Nassar, o casal protagonista se entrega muitas vezes à quietude amorosa, com a mesma facilidade que abraça as discussões ruidosas ou o mutismo da cólera, sentimento que já está indicado no título da obra.

Os personagens desse texto às vezes se sentem como num teatro, interpretando uma farsa. Mas, em outros momentos, eles se vêem numa tragédia e essa associação ora é feita em tom de deboche, ora parece ser compreendida de modo grave:

o velho macaco na casa de louças, falando ainda por cima nesse tom trágico como protótipo duma classe agônica...

[...] fiquei um tempo ali parado, olhando o chão como um enforcado, o corpo enroscado nas tramas da trapaça, estraçalhado nas vísceras pela ação do ácido, um ator em carne viva, em absoluta solidão. [Nassar, 1995, p. 78-79].

Solidão e silêncio são dois atributos do personagem trágico, segundo Walter Benjamim, em Origem do drama barroco alemão: O herói trágico tem apenas uma linguagem que lhe corresponde plenamente: o silêncio. [...]. Enquanto silencia, o herói rompe as pontes que o ligam a Deus e ao mundo e se eleva na gelada solidão do si-mesmo, acima da esfera da personalidade que, falando, se demarca e se individualiza em relação aos outros. O si-mesmo nada sabe sobre o que lhe é exterior, ele é, pura e simplesmente, solitário. [Benjamin, apud: Chaves, 1999, p. 118].

Antes de Benjamim, o silêncio trágico já havia sido estudado por Nietzsche, em sua obra $O$ nascimento da Tragédia, como comenta a estudiosa Jucimara Tarricone: Ao criticar o racionalismo socrático e a verbalização do teatro arcaico de Atenas, [Nietzsche] põe em realce o 
caráter mais corporal da encenação trágica, uma vez que, nesse caso, a linguagem conceitual é substituída pela poesia musical, pela dança, pela eloqüência do silêncio ulterior à cena mágica embalada por sons, ruídos e clamores. [Tarricone, 1997, p. 20].

Apesar de não ser exatamente uma tragédia, Um copo de cólera coloca em realce o caráter mais corporal, mas, muitas vezes, nem com o corpo os personagens querem se manifestar, mostrando verdadeiro apreço por mais uma outra faceta do mutismo: a incomunicabilidade. Isso significa que os comentários e as perguntas de um interlocutor têm, como resposta do outro, a quietude de quem não está disposto a conversar.

Assim, o casal da história tem, entre alguns diálogos, a presença implacável da bolha envenenada de silêncio [Nassar, 1995, p. 16] incomunicável, como aquela do início da obra:

estávamos os dois em silêncio quando ela me perguntou "que que você tem?", mas eu, muito disperso, continuei distante $e$ quieto, o pensamento solto na vermelhidão lá do poente, $e$ só foi mesmo pela insistência da pergunta que respondi "você já jantou?" e como ela dissesse "mais tarde" eu então me levantei e fui sem pressa pra cozinha (ela veio atrás), tirei um tomate da geladeira [...] por baixo do seu silêncio ela se contorcia de impaciência, [...], sem dizer uma palavra entramos quase juntos na penumbra do quarto. [Nassar, 1995, p. 10-11].

Em Lavoura arcaica, também de Nassar, os sentidos dos silêncios transformam-se a cada página, pois há o piedoso mutismo [Nassar, 1982, p. 33], o silêncio recatado [Nassar, 1982, p. 37], o silêncio de cristaleiras [Nassar, 1982, p. 39], o arrumado silêncio [Nassar, 1982, p. 39-40], o silêncio fúnebre [Nassar, 1982, p. 61-62], o silêncio dos corredores, [Nassar, 1982, p. 80], o silêncio úmido [Nassar, 1982, p. 80], o silêncio de morcegos, [Nassar, 1982, p. 101], a quietude escura [Nassar, 1982, p. 111], o silêncio recluso [Nassar, 1982, p. 131], o silêncio carregado de vibrações e ressonâncias [Nassar, 1982, p. 133], a quietude da ave que choca os ovos 
no seu ninho [Nassar, 1982, p. 143].

Cruz e Sousa, antes de Raduan, já exaltava a multiplicidade semântica do silêncio, usando, inclusive, essa palavra no plural, como se vê no título do poema que serve de epígrafe para este capítulo. O poeta simbolista, naquele escrito, aponta que os calares podem ser interpretativos, lenitivos, adoçados por funda nostalgia, sugestivos, vácuos fecundos de celestes raios de sonho.

Ao percorrer outros escritos do Cisne Negro, pode-se notar a continuidade das alternâncias semânticas do mutismo, tendo-se, então, o silêncio carregado e fundo e denso [em "Tédio"], o silêncio vago, bíblico, pungente/De todas as profundas liturgias, [em "Ângelus..."], o silêncio d'alma [em "Recorda"], o silêncio para o desespero insano [em "Perante a morte"], o silêncio das noites estreladas [em "Invulnerável], o silêncio sem quimera [em "Envelhecer"], o silêncio escuro [em "Vida obscura"], os silêncios graves [em "Monja negra"], silêncios solitários [em "Cárcere das almas"], o silêncio formidável [em "Luar de lágrimas"], o silêncio astral da Imensidade [em "Violões que choram"], o silêncio de ascetérios [em "Vesperal"], a mudez infernal, o mutismo horrível que não gera nada [em "Mudez perversa"] e o eterno silêncio dos Espaços [em "Imortal atitude"] etc.

Assim, há mutismos diversos tanto nos espaços terrestres quanto nos celestes e Peter Burke, em "Escutar o silêncio", mostra que há uma Geografia de silêncios: Alguns povos falam menos do que outros; os europeus do norte, por exemplo, falam menos do que os do sul, como os italianos ou gregos. A minha impressão dos brasileiros é que eles acham os ingleses artificial, incrível e até patologicamente silenciosos, um estereótipo reforçado pelo famoso filme do diretor Ingmar Bergman, "O silêncio" (1963). Para os suecos, por outro lado, o povo silencioso por excelência são os finlandeses. [Burke, 1999, p. 4].

Em outro ensaio, "Anotações para uma história do silêncio no início da Europa Moderna", último capítulo de seu livro A arte da conversação, Burke 
indica que a noção do espaço oferece especificidade para o emudecer, já que é muito peculiar, por exemplo, o "silêncio localista" dos templos e bibliotecas. [Burke, 1995].

No silêncio dos templos, ocorre o mutismo de cunho místico, que, segundo o estudioso, está presente em religiosidades de tempos diversos: Na Antiguidade clássica, o silêncio religioso - "o silêncio sagrado" como o chamava Horácio - foi bem documentado. [...]. Plutarco declarou que o silêncio é algo "profundo e terrível" e que aprendemos o silêncio dos deuses, e o falar dos homens. [...]. As reformas católica e protestante tiveram efeitos sobre o falar e o silêncio da mesma forma que sobre muitos aspectos da vida cotidiana. [...]. Normalmente não se pensa em Martinho Lutero como um homem quieto, mas parece que os hábitos da clausura não eram fáceis de serem mudados. [...], segundo uma testemunha, Johannes Mathewsius, ele às vezes ficava em silêncio durante toda a refeição, à maneira de seu antigo mosteiro.

Márcia Sá Cavalcante Schuback, em "Quando da palavra se faz silêncio", mostra o mutismo ligado à Teologia Negativa. Para os teólogos negativos, o dizer humano é imperfeito e limitado para falar da natureza de Deus, que teria uma linguagem perfeita e livre do limite. Assim, o que recomendam é a economia do verbo e, na seqüência, a sua suspensão. É o que Schuback mostra, citando Mestre Eckhart: Agora não se trata nem mais de concisão, mas de um inteiro cessar da palavra e do pensamento. Lá (na afirmação) onde nosso discurso descia do superior para o inferior, à medida que tomamos a subida do inferior para o superior, à medida que nos aproximamos do cimo, o volume de nossas palavras se apaga. No final da última subida, estaremos inteiramente em silêncio e unidos ao inefável.

Ernst Cassirer, em Linguagem e mito, anota outra idéia importante de Mestre Eckhart: Deus é a simples causa, o quieto deserto, o simples silêncio. [apud: Cassirer, 1972, p. 91]. Já que Deus é mudez, só seria possível aproximar-se d'Ele não pela palavra, mas pela adesão silenciosa a Ele. Em "Os nomes divinos", Pseudo-Dionísio, o Areopagita, afirma: [É necessário] aderir sem palavras e sem saber às realidades indizíveis e 
incognoscíveis, unindo-nos com elas para além dos nossos modos de raciocinar e compreender.

Modesto Carone, em A poética do silêncio, mostra um outro tipo de inarticulabilidade: o pavoroso emudecimento [Celan, apud: Carone, 1979, p. 101] ligado aos campos de concentração, presente na poesia de Paul Celan. O autor era judeu romeno e não deixou de incluir, em sua obra, esse tipo de mutismo, do qual também tratou Adorno. É célebre esta frase do pensador: Depois de Auschwitz era barbárie escrever poesia.

Outro filósofo da escola de Frankfurt também se pronunciou com relação a esse tipo de silêncio: Walter Benjamin, em "O narrador". Nesse célebre ensaio, ele afirma: No final da guerra, observou-se que os combatentes voltavam mudos do campo de batalha não mais ricos, e sim mais pobres em experiência comunicável. [Benjamin, 1994, p. 198].

Eni Puccinelli Orlandi, em As formas do silêncio: no movimento dos sentidos, enuncia: Reduto do possível, do múltiplo, o silêncio abre espaço para o que não é "um", para o que permite o movimento do sujeito. [Orlandi, 1995, p. 13].

Para comprovar que o mutismo não se reduz ao que é um e sim se alarga para o múltiplo, Eni afirma que ele pode ser dos seguintes tipos: contemplativo, introspectivo, de resistência, de disciplina, de exercício do poder, de derrota da vontade etc. [Orlandi, 1995, p. 44].

Um exemplo de silêncio como derrota da vontade está em Macunaíma, de Mário de Andrade: a inarticulabilidade faz-se presente quando o protagonista e os seus irmãos, depois de procurarem em vão a muiraquitã, um amuleto dado por Cy a Macunaíma, deixam-se abater por um quieto desânimo.

Macunaíma, como notou Flávio Aguiar [1988, p. 30], inicia-se e finaliza-se com o silêncio. Tal ciclicidade contribui para o caráter mítico da obra. O protagonista passa seus seis primeiros meses de vida sem falar; isso, somado ao fato de o romance iniciar com o silêncio, pode apontar para o silêncio primordial, ou seja, aquele de caráter mítico, que indica o mutismo anterior à invenção da linguagem. 
Gilberto Mendonça Teles, na introdução do seu livro A retórica do silêncio, afirma: Para a mitologia mais primitiva (a sumérico-babilônica, por exemplo), as coisas só tinham existência quando os deuses pronunciavam o nome delas. [...]. Antes do nome, o caos, o silêncio. Sair do silêncio é criar, isto é, começar a organizar um universo na linguagem. [Teles, 1989, p. 16].

Theodor Reik afirma: Devemos supor que o silêncio é essencial e que a palavra nasce do silêncio como a vida do inorgânico, da morte. [...]. Como no Evangelho de João, devemos acreditar que no início era o verbo, mas antes havia o grande silêncio. [Reik, 1989, p. 20, nota de rodapé].

Na trajetória da Humanidade, Eni Puccinelli Orlandi entende que o homem nos primórdios estava mais ligado ao silêncio enquanto o ser contemporâneo, envolvido com a ciência, está mais próximo à palavra. Eni apresenta o seguinte gráfico para demonstrar essa transformação²:

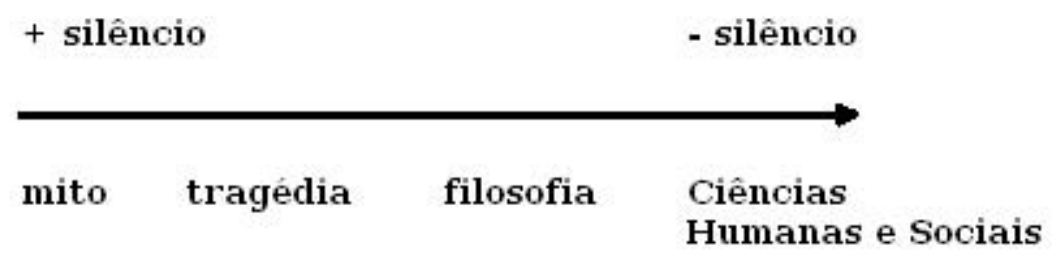

Retomando Macunaíma, há um trecho do livro em que o silêncio se associa ao calor do sol e à preguiça típica do protagonista: Principiou um calorão que tomou a jangada, se alastrou nas águas e dourou a face limpa do ar. Macunaíma deitado na jangada lagarteava numa quebreira azul. E o silêncio alargando tudo... - Ai... que preguiça... [Andrade, 2004, p.66].

E o silêncio alargando tudo..., essa frase resume bem as amplidões

\footnotetext{
${ }^{2}$ A pesquisadora comenta o quadro: No mito, a significação prescinde da explicação cabal de seus modos de significar. Já na tragédia essa explicitação começa a se alargar. [...]. No caso da filosofia, se passa para um outro discurso, em que se tematiza vastamente o sentido em sua relação com o ser. Percurso que desemboca nas Ciências Sociais $e$ Humanas, que se instituem em várias disciplinas diferentes com distintos objetos $e$ discursos diversos para falarem dessa mesma coisa. Dominado pelas múltiplas metalinguagens, o fato tem de significar nas diferentes "explicações" que, por sua vez, o povoam de muitos signos. Exílio do silêncio. [Orlandi, 1993, p. 38-39].
} 
semânticas da inarticulabilidade na obra andradiana, pois nos "Poemas da negra", o sujeito poético afirma que há o mutismo exaltado dos astros [Andrade, p. 251] e que existe um silêncio nortista muito claro [Andrade, p. 267]. Já em "Atrás da Catedral de Ruão", de Contos novos, aparecem o silêncio infeliz [Andrade, 1993, p. 58], os silêncios desagradáveis (Andrade, 1993, p. 63) e o silêncio torvo [Andrade, 1993, p. 69]. No poema “O grifo da morte", do Livro azul, aparece o silêncio monótono e, em Clã do jabuti, surge o silêncio fresco da noite deserta [Andrade, p. 179]. Nesta obra, o mutismo, ao deslocar-se por Belo Horizonte, muda de sentido de acordo com os espaços pelos quais passa: Silêncio brincalhão salta das árvores,/ Entra nas casas desce as ruas paradas/ E se engrossa agressivo na praça do Mercado. [Andrade, p. 184].

No poema "Danças", o sujeito poético afirma: Converso pouco $e$ escuto muito [Andrade, 222] e no "Improviso do mal da América", do mesmo autor, vem a afirmação: meus ouvidos vão escutar amorosos/ Outras vozes de outras falas, de outras raças, mais formação, mais forçura. [Andrade, p. 266]. Em ambos os casos, está evidenciado o silêncio da escuta.

Macunaíma celebra a dedicação do seu autor em emudecer para ouvir o Brasil, já que palavras e expressões de diferentes regiões nacionais aparecem no livro, como do Rio Grande do Sul (piá), de Minas Gerais Gerais (trens - no lugar de coisas), e do Nordeste (tem mais não, indicando o fim da história).

Uma das reivindicações mais incisivas de Oswald de Andrade era que gramáticos e filólogos silenciassem para ouvir o dizer popular, como fica patente no poema "Pronominais", do autor de Memórias sentimentais de João Miramar.

A mesma reivindicação é feita por Mário no artigo "A língua nacional"; depois de elogiar a mudança à época de alguns filólogos que passaram a valorizar o dizer popular, nota que o trabalho não está completo: Agora só nos falta o passo definitivo, que será ver tais e tão doutos filólogos "errarem" também a colocação dos seus pronomes. "Me parece" que nada 
mais poderíamos desejar então... [Andrade, 1993, p. 178].

Em outro local, a Rússia, e num diverso tempo, o século XIX, Nikolai Gógol já registrava discursos populares. Mikhail Bakhtin notou a importância da escuta para os textos desse autor, mostrando que ele era um exímio audiente das histórias do povo difundidas em feiras e festas. [Bakhtin, 2002, p. 430].

Bakhtin e sua teoria da paródia [o parodiar é a criação do duplo destronante, do mundo "às avessas"3] são usados por Arlete Cavaliere, em seu ensaio "A magia das máscaras", para analisar "O nariz", de Gógol.

Arlete observa que os elementos paródicos da narrativa estão presentes nos vários "cantos paralelos" [vide noção de paródia de Haroldo de Campos], que se apresentam no espaço do jornal e o vozerio popular, no dizer textual [o do narrador], no falar de Kovalióv, na voz do nariz, com vida própria, na presença do discurso auto-reflexivo sobre a própria narração, etc..

Em "A terrível vingança", outra narrativa gogoliana, segundo Arlete, ocorre a presença da História (já que são contados os conflitos entre cossacos e poloneses/turcos) e do Mito: $O$ mergulho gogoliano no passado histórico russo o arrasta à esfera mítica. Vimos que o mundo de "A terrível vingança" é "explicado" expressamente no epílogo, pela voz do bandurrista que menciona a lenda eslava sobre a traição e inveja entre dois cossacos irmãos, lenda calcada na mitologia eslava pagã através da figura do bogatir, o cavaleiro que cavalga as montanhas dos Cárpatos.[Cavaliere, 1990, p. 173-174].

O silêncio da escuta tem destaque no conto "Um casal à moda antiga", de Gógol. Nessa narrativa, aparecem Pulkéria e Atanásio, que viviam sob um encanto inexpremível [Gógol, 1974, p. 70] em sua propriedade, sempre invadidos por uma sensação deliciosa de quietude [Gógol, 1974, p. 70].

O casal era muito afeito ao mudo ouvir principalmente quando um deles se dispunha a contar histórias: Atanásio Ivanovitch gostava de estar sentado curvado e tinha um sorriso quase permanentemente nos lábios,

3 [Cavaliere, 1990, p. 110] 
quer quando contava uma história, quer quando se limitava a escutá-la. [Gógol, 1974, p. 71].

Atanásio adorava visitas para justamente colocar em ação o exercício da escuta silente; assim, ele se punha curvado sobre a cadeira, com um eterno sorriso nos lábios, a escutar muito atento, a beber gulosamente as palavras do seu hóspede. [Gógol, 1974, 83]. A muda audição permite ao casal ouvir a fala e o canto da sua casa: A verdade é que cada porta tinha o seu cantar próprio: a porta do quarto de dormir tinha uma voz aguda de tenor, a da sala de jantar a voz roufenha dum baixo, a da antecâmara produzia um som estranho, frágil, queixoso, que escutado com atenção se acabava por distinguir claramente: pobre de mim, estou gelada." [Gógol, 1974, p. 74].

A novela $O$ capote é resultado do silencioso e proveitoso ouvir de Gógol, já que a história escrita foi inspirada em uma outra, oral, que chegou aos ouvidos do autor: um homem muito economiza o pouco que ganha para comprar uma espingarda de caça, que é roubada no mesmo dia em que é adquirida.

O capote conta a história de Akaki Akakievitch, funcionário público que, depois de investir o pouco que ganhava na reforma de seu capote, vê essa querida peça de seu vestuário ser roubada em uma praça. Ele se dirige ao chefe de segurança do município, que o deixa na sala de espera, dias seguidos, sem atendê-lo: os pequenos são ignorados e seus direitos são negados. Akaki morre de desgosto e reaparece, em forma de espectro, ao chefe de segurança, que se desespera numa corrida movida pelo medo e pela culpa de não ter ouvido o funcionário público ${ }^{4}$.

O silêncio da escuta, o engrandecimento dos pequenos e o destaque à

\footnotetext{
${ }^{4}$ Victor Brombert, no terceiro capítulo do seu Em louvor de anti-heróis, chama a atenção do leitor para um personagem secundário, mas importante na narrativa: um rapaz recémnomeado na repartição que está prestes a caçoar de Akaki, no entanto, ao se dirigir a ele ocorre uma verdadeira revelação proveniente de uma força "sobrenatural" ("neeste'stvennaia") que permite-lhe ouvir outras palavras por trás do pedido banal de Akáki para que o deixem em paz. O que o rapaz ouve são as palavras profundas $e$ pungentes, não pronunciadas mas ressoantes de dolorosa significação: "Eu sou teu irmão". E com esta voz saída de trás da voz vem a chocante percepção de quanta "desumanidade" há nos seres humanos, quanta brutalidade se esconde no que passa por ser sociedade civilizada e comportamento civilizado. [Brombert, 2001, p. 47].
} 
fantasmagoria são heranças deixadas a um outro autor russo: Fiódor Dostoievski. Certa vez, o autor de Humilhados e ofendidos afirmou: Todos nós viemos do Capote de Gógol.

O audiente mutismo é muito recorrente na obra de Guimarães Rosa. Os animais da mata escura são alvo dos ouvidos de alguns personagens da novela "Buriti": bastando a gente guardar um pouco o silêncio, e o confuso de sons rodeava, tomava conta. [...]. Da treva, longe submúsica, um daqueles acreditava perceber também, por trás do geral dos grilos, os curiangos, os sapos, o último canto das saracuras e o belo pio do nhambú. [...]. Miguel assestara o ouvido. Orgulhava-se de ainda entender o mundo de lá. [Rosa, 2006, p. 630]. Ao assestarem o ouvido, em pleno breu noturno do sertão, Miguel e outros caçadores se dispõem a separar os sons, tentando reconhecer os bichos que os emitem. Mas quem consegue fazer isso com maestria, acertando sempre, é Zequiel, o chefe, em suas noites de insônia. Ele, segundo o narrador, é o homem que chamava os segredos todos da noite para dentro de seus ouvidos. [Rosa, 2006, p. 657].

O Chefe não sabe ler, mas é o mestre do competente ouvir. Em certa passagem do escrito, Maria da Glória pergunta: - Que é que adianta, escutar, essas noites em que o que tem é só chuvarada de chuva? [Rosa, 2006, p. 744]. A resposta do chefe é: Ah, nhãnão, sinhazinha: tem muitas toadas de chuvas diferentes. [Rosa, 2006, p. 745].

Outro personagem desse texto rosiano, imerso no seu silenciosão [Rosa, 2006, p. 645], é Iô Liodoro, que se põe a escutar, quieto, as conversas de suas filhas Maria da Glória, Maria Behú, do amigo Gual e da enteada Lala. Assim, Liodoro com os ouvidos atentos e com a boca cerrada é um mistério para os outros, que não conhecem seus pensamentos: ele era quieto e opaco [Rosa, 2006, p. 686].

Os mutismos têm grande importância em "A menina de lá", do livro Primeiras estórias, já que em muitas situações Nhinhinha põe-se avessa à fala: Em geral, porém, Nhinhinha, com seus nem quatro anos, não incomodava ninguém, e não se fazia notada, a não ser pela perfeita calma, imobilidade e silêncios. [Rosa, 1988, p. 22]. 
Essa criança oscila entre o verbo osbscuro e a mudez:

Não que parecesse olhar ou enxergar de propósito. Parava quieta não queria bruxas de pano, brinquedo nenhum, sempre sentadinha onde se achasse, pouco se mexia. - "ninguém entende muita coisa que ela fala..." - dizia o Pai, com certo espanto. Menos pela estranhez das palavras, pois só em raro ela perguntava, por exemplo: - Ele xurugou?" - e vai ver, quem e o quê, jamais se saberia. Mas, pelo esquisito do juízo ou enfeitado do sentido. (Rosa, 1988, p. 22)

Um dos silêncios de Nhinhinha é dedicado à escuta: Ouvia o pai querendo que a mãe coasse um café forte, e comentava, se sorrindo: "Menino pidão..." Costumava também dirigir-se à Mãe desse jeito: - "Menina grande... Menina grande..." . [Rosa, 1988, p. 23].

Passarinho desapareceu de cantar; essa fala de Nhinhinha pode apontar para aquela que esperava por ela: a morte. Assim, o passarinho, que sempre se punha a cantarolar, morreu e sua ausência é detectada pelos ouvidos: o sumiço do seu canto revela o silêncio da ausência, o mutismo da morte. Todos silenciaram demais [Rosa, 1988, p. 24] diante dos milagres de Nhinhinha e de uma de suas previsões: o próprio falecimento.

A morte gera silêncios: ela avisa que não serão mais ouvidas as vozes daqueles que ele leva; o dizer se interrompe com o óbito e o resto é silêncio... Não por acaso essa famosa frase de Hamlet é dita depois de um desencadear de passamentos.

A psicanalista Jacqueline Moulin, no seu ensaio "Um assim lento... um silêncio de morte", afirma: No dia seguinte à morte de Merleau-Ponty, C. Lefort abriu seu posfácio à edição da última obra do filósofo - $O$ visível e o invisível - com a seguinte exclamação íntima: "Estranho silêncio, este, em que nos abandona o discurso interrompido...". [Moulin, 1989, p. 145.].

Com a boca atingida pela imobilidade letal, aquele que falece permanece na quietude, como mostra "A canção", de Mário Quintana:

Era a flor da morte/E era uma canção.../Tão linda que só se poderia ler dançando/estava fragilmente pintada sobre o véu do silêncio/Onde a morta, 
jazia com os seus cabelos esparsos/ [...]/ Com os seus lábios imóveis/ E que talvez houvessem desaprendido para sempre até as sílabas com que outrora pronunciavam meu nome...

No conto "O silêncio branco", de Jack London, o casal Mason e Ruth, acompanhados do amigo Kid Malemute, tentam escapar do terrível silêncio branco, ou seja, da alva inarticulabilidade que está associada ao falecimento, pois é quando a branquidão do gelo, em países da parte superior da América do Norte, toma tudo e, assim, não se têm mais os cantos dos pássaros, que fogem para lugares mais quentes, nem o ruído dos movimentos dos rios, pois eles se petrificam. O silêncio é, pois, a morte da qual os mais incautos ou os mais lentos podem ser vítimas, como é o caso de Carmen, uma cadela, que carregava um trenó com bagagens. Eles tentam chegar a um lugar cálido, mas um dos homens, também, é abatido pelo silêncio branco; o frio mortífero cobre Mason depois que uma árvore cai sobre ele, deixando-o imobilizado. Mason pede a Kid Malemute que atire nele, e que siga em frente, juntamente com Ruth, para não serem devorados pela geleira que traz a mudez.

Os mortos não têm voz, não conseguem reclamar sobre o abuso e a ganância dos vivos em "A nova Califórnia", narrativa de Lima Barreto, na qual toda a cidade de Tubiacanga, menos o bêbado Belmiro, vai ao quieto lugar de lápides e cruzes com um único intento: pegar ossos de familiares e desconhecidos, já que, segundo o estranho alquimista Raimundo Flamel, os ossos humanos podem ser transformados em ouro. Sem gritar ao terem suas carnes rasgadas, sem poder expor qualquer tipo de palavra para denunciarem o espetáculo tosco, os mortos jazem no mutismo.

A idéia de que o reino da morte é o do silêncio aparece no conto " $\mathrm{O}$ cemitério", também do autor carioca, no qual o espaço mencionado no título, ou seja, o campo de mortos [Barreto, 2005, p. 332], é definido como um mudo laboratório de decomposição. A inarticulabilidade está presente também entre os vivos, que abalados pelo passamento, seguem avessos a conversas conduzindo alguém para a sua última e silente morada: Pelas 
ruas de túmulos, fomos calados. [Barreto, 2005, p. 332].

Mas, às vezes, no universo barretiano os mortos não emudecem, como em "Carta de um defunto rico", em que um abastado morto redige uma missiva aos parentes, mostrando sua indignação com relação às roupas velhas dos cocheiros na hora do seu enterro.

No conto "Bobok", de Fiódor Dostoiévski, o narrador, ao entrar em um cemitério, pensando que ia encontrar um silêncio digno do lugar, percebe o quanto se enganara. Ele, então, emudece para ouvir os cadáveres que conversam em baixo da terra: E eu escutava: sons surdos, como se as bocas estivessem tapadas por travesseiros; $e$, a despeito de tudo, nítidos e muito próximos. [Dostoiévski, 2005, p.22].

O falatório fúnebre estende-se e o narrador não quer perder nenhum detalhe dele, mas, depois de muito ouvir, espirra e só assim os mortos emudecem: tudo ficou em silêncio, exatamente como no cemitério, desapareceu como um sonho. Fez-se um silêncio verdadeiramente sepulcral. [Dostoiévski, 2005, p. 37].

Um célebre morto que muito discursa é Brás Cubas. No entanto, há situações em que se cala:

Capítulo CXXXIX - DE COMO NÃO FUI MINISTRO D'ESTADO

No capítulo seguinte, o narrador afirma: Há coisas que melhor se dizem calando; tal é matéria do capítulo anterior. [Assis, 1984, p. 132].

Em Dom Casmurro, momentos quietos ganham tremenda força, pela 
tensão que geram, como o desta passagem do capítulo CXXXVIII: Seguiu-se um daqueles silêncios, a que, sem mentir, se podem chamar um século, tal é a extensão do tempo nas grandes crises. [Assis, 1982, p. 144].

Dom Casmurro é livro lido e relido não só pelas suas palavras mas pelos seus silêncios. Ocorre ao menos duas vezes o calar de Capitu: no foco narrativo, já que não é ela quem conta a história, e no momento em que lhe é dada a oportunidade de se defender (a resposta é seu enigmático emudecimento). Além do silêncio da personagem, há também o da obra que ganha força nos seus subtextos, que são fundamentais, pois o livro não afirma uma traição ou uma fidelidade, ele apenas silenciosamente as sugere como possibilidades. O verbo, então, associa-se ao silêncio de quem não informa categoricamente mas sim celebra a ambigüidade.

Boris Schnaiderman, em resenha à tradução de T. Ivanova para o russo de Dom Casmurro, publicada na Revista do Instituto de Estudos Brasileiros, em 1968, percebe o silenciar do livro: o crítico afirma que traduzir esse texto machadiano é tarefa plena de dificuldades, pois há certo negacear de quem diz e não diz. [Schnaiderman, 1968, p. 141].

Se há, pois, muitos silêncios no meio das muitas palavras de Memórias Póstumas de Brás Cubas e Dom Casmurro o que dizer quando Machado se serve da economia verbal dos contos?

Em introdução a uma coletânea de contos machadianos, de períodos diversos, Flávio Aguiar afirma: Os silêncios são terríveis: as histórias escondem um segredo qualquer, uma palavra ou gesto que é impossível precisar qual seja, mas, sabemos, quebraria o encanto, espatifaria o espelho das convenções e poria os personagens ao lado de sua própria realidade. Talvez esta seja a "lição" (ou o sentido) mais contundente de Machado: o silêncio que há no meio das falsidades, das frases vazias e sonoras, desse mundo oco e inautêntico de escravidão e pancadas onde vivem seus personagens. [Aguiar, 1997, p. 5-6].

Quietez e servidão associam-se no conto "Só!", Tobias impõe mudez ao seu criado: Costumava ele desaparecer da cidade durante um ou dous meses; metia-se em casa, com o único preto que possuía, e a quem dava 
ordem de lhe não dizer nada [Assis, 1992, p. 1044].

Existe, nesse caso, o que Eni Orlandi chamou de política do silêncio ou silenciamento: Aí entra toda a questão do "tomar a palavra", "tirar a palavra", obrigar a dizer, fazer calar, silenciar etc. Em face dessa sua dimensão política, o silêncio pode ser considerado tanto como parte da retórica da dominação (a da opressão) como de sua contrapartida, a retórica do oprimido (a da resistência). [Orlandi, 1995, p. 31].

Nesse conto, o poder de Tobias é medido no "tirar a palavra" do escravo, que nem é considerado como uma presença:

Bonifácio, um dos seus poucos familiares, perguntou-lhe um dia que prazer achava naquelas reclusões tão longas e absolutas; Tobias respondeu, que era o maior regalo do mundo.

- Mas, sozinho! Tanto tempo assim, metido entre quatro paredes, sem ninguém!

- Sem ninguém, não.

- Ora, um escravo, que nem sequer lhe pode tomar a benção!

- Não, senhor. Trago um certo número de idéias; $e$, logo que fico só, divirto-me em conversar com elas. [Assis, 1998, p. 265].

Na seqüência, Tobias vai para um sítio, afastando-se da cidade, porque é metido a filósofo e, assim, entende que precisa de quietude e isolamento para fazer suas reflexões. Isso tem um tom irônico no caso do pseudofilósofo do texto machadiano, mas para os verdadeiros filósofos tem uma repercussão séria: a solidão e a mudez são fundamentais para os pensadores, como mostra Nietzsche, em Assim falou Zaratrustra e Gilvan Fogel, no seu ensaio "A respeito do fazer necessário e inútil Ou do silêncio", em que comenta o livro nietzschiano: Aí está o homem, o tipo de silêncio de solidão. De silêncio, isto é, feito por ele, por ele atravessado $e$ performado, então, por ele cunhado, forjado, modelado. O silêncio é mesmo metalurgia do próprio, da identidade. Forja da verdade e da liberdade. Lugar único do real. A Vida, todo real possível, é, precisa ser, per-feição de 
silêncio e solidão. [Fogel, 1996, p. 56]

O assunto já havia interessado Platão que mostra que o homem que se entrega à reflexão estabelece uma ensimesmada comunicação silenciosa:

$O$ que chamas assim? [de pensamento]

Uma conversação que a alma mantém consigo mesma, a respeito do que é eventualmente o objeto do seu exame. [...] essa imagem que eu faço da alma que está pensando não é nada mais que a de uma conversa, na qual ela faz perguntas a si mesma e dá respostas a si mesma, seja afirmando, seja negando. [...]. Por conseguinte, chamo "julgar" de "falar"; chamo a opinião, o julgamento, de uma "enunciação" de palavras", que, na verdade, não se dirige a outrem, que também não se faz por meio da voz, mas silenciosamente e falando consigo mesmo. [Platão, Teeteto, 189e-190a, apud: Nef, 1995, p.20].

No conto "Ponto de vista", do livro Histórias da meia noite, de Machado de Assis, a personagem Raquel, faz silêncio para escutar-se com precisão. Ela afirma: Gosto imensamente destes grandes silêncios, porque então ouço-me a mim mesma, e vivo mais em cinco minutos de solidão do que em vinte horas de bulício. [Assis, 1977, p. 207].

Às vezes, é preciso ouvir a voz do outro para escutar a sua própria, como faz D. Paula, de uma narrativa homônima, também de Machado. Ela, depois de silenciar para ouvir a sobrinha, ficou bastante impressionada com o que escutou e nos momentos quietos vinha um eco a partir de um substantivo próprio: Vasco (um rapaz que gerou ciúme em Conrado, esposo de Venancinha). Esse nome soa perturbador e delicioso, para a tia, já que é o mesmo de um namorado que teve quando nova e já casada; mais desconcertada fica quando descobre que este Vasco é filho, justamente, daquele outro.

A sobrinha tenta convencer a tia de que não alimenta nenhum afeto pelo moço. Buscando sentidos ocultos nas palavras, a senhora se mostra uma exímia leitora do não-dito, atendo-se às lacunas silentes da fala de 
Venancinha: D. Paula tinha o bom costume de não ler às carreiras, como quem vai salvar o pai da forca, mas devagar, enfiando os olhos entre as sílabas e entre as letras, para ver tudo. [Assis, 1989, p. 129].

Mensagens não verbalizadas do discurso de Venancinha levam D. Paula a concluir: - Eles amam-se! [Assis, 1989, p. 129]. Esse pensamento da tia, que não é pronunciado, ganha confirmação depois de alguns dias de convívio mais intenso entre as duas.

Servindo-se novamente do silêncio da escuta, D. Paula quietamente se deleita com as palavras de Venancinha, pois, emudecendo, ouve a sobrinha e a si própria, de anos atrás, que convivia com o prazer e o medo gerados por um amor deliciosamente arriscado.

Para ouvir a si própria, D. Paula é auxiliada pela experiência da silente escuta da natureza:

Ventava um pouco, as folhas moviam-se sussurando, e, conquanto não fossem as mesmas do outro tempo, ainda assim perguntavam-lhe: "Paula, Você lembra-se do outro tempo, ainda do outro tempo? Que esta é a particularidade das folhas, as gerações que passam contam às que chegam as cousas que viram, e é assim que todas sabem tudo e perguntam por tudo. Você lembra-se do outro tempo? [Assis, 1989, p. 133].

Em Livro de perguntas, do autor egípcio Edmond Jabès, o narrador também põe-se a escutar a voz de outros tempos, vinda com o vento ou presente no ar parado do deserto: Antes de conhecer o deserto, eu sabia que ele era meu destino. Somente a areia pode acompanhar uma palavra muda até o horizonte. Escrever sobre a areia, à escuta de uma voz de outros tempos, os limites abolidos. Voz violenta do vento ou, imóvel, do ar, esta voz vos enfrenta. O que ela anuncia é o que vos agride ou esmaga. Palavra das abissais profundezas das quais sois somente um ininteligível rumor; sonora ou inaudível presença. [Jabès, apud: Meira, p. 1999, p. 131].

Alceu Amoroso Lima, nos capítulos 9 e 10 de Meditação sobre o mundo interior, livro de 1955, discorre sobre a importância da inarticulabilidade para a alma, localizando o problema do desperdício 
sonoro nas metrópoles. Afirma que chegaram aos seus ouvidos informações que, na capital do México, no Canadá, em Portugal e na Itália, movimentos contra a tirania da buzina [Lima, 1955, p. 61] eram empreendidos. Aliados às buzinas, o barulho dos alto-falantes nas ruas e o alarido produzido pelas fábricas acabam, muitas vezes, apartando os homens do equilíbrio e da sensibilidade.

Se a exterioridade é barulho, a interioridade deve se voltar para a inarticulabilidade. Amoroso apresenta as características desse necessário silêncio interior:

\begin{abstract}
À medida que nos retiramos ao centro de nós mesmos, à medida que cresce esse silêncio profundo da alma, vão-se delineando as formas do pensamento, o passado ressurge mais claro do esquecimento, a atenção se apura, cresce a agudez dos juízos, os sentidos interiores ganham forma à medida que se tornam mais discretos os sentidos exteriores, a luz da inteligência se torna mais viva e a vontade mais firme. Começamos então a sentir melhor o nosso eu, o que fica tantas vezes escondido em nós, por falta de silêncio. [Lima, 1955: 64-65].
\end{abstract}

Antonio Vieira, em "O sermão de Santo Antônio ou O sermão dos peixes", afirma que há certas histórias que podem arrebatar os audientes: Vai um pregador pregando a paixão, chega ao Pretório de Pilatos, conta como a Cristo o fizeram rei de zombaria, diz que tomaram uma púrpura $e$ lha puseram aos ombros; ouve aquilo o auditório muito atento. Diz que teceram uma coroa de pinhos e que lha pregaram na cabeça; ouvem todos com a mesma atenção. Diz mais, que lhe ataram as mãos e lhe meteram nelas uma cana por cetro; continua o mesmo silêncio e a mesma suspensão nos ouvintes. Corre-se neste espaço uma cortina aparece a imagem do Ecce Homo; eis todos prostrados por terra, eis todos a bater no peito, eis as lágrimas, eis os gritos, eis os laridos, eis as bofetadas. [Vieira, s. d., p. 11].

O silêncio escuta, afirma Mário Quintana, e muito antes, no ano $100 \mathrm{~d}$. C, Plutarco, já estudava a mudez audiente, na quarta seção do tratado 
Como ouvir, intitulada "Elogio do silêncio". Ele lembra o pensamento popular de que devemos mais ouvir do que falar, pois temos dois ouvidos e apenas uma boca. [Plutarco, 2003, p. 12]. Além disso, afirma: A maioria das pessoas, ao beijarem ternamente as criancinhas, tocam as orelhas delas $e$ as exortam a fazerem o mesmo, dando-lhes a entender, de maneira pueril, que devem amar especialmente os que nos beneficiam por meio dos ouvidos. [Plutarco, 2003, p. 9].

Defendendo a tese de que o ouvido é o órgão da sabedoria [2003, p. 9], Plutarco mostra a necessidade do silêncio, para que, com método, sejam aproveitadas ao máximo as experiências auditivas: o silêncio é para o jovem um seguro adorno, principalmente quando, ao escutar outro, não se excita, nem exclama a cada instante, mas, [...] se contém e espera que o palestrante acabe de falar; ainda assim não opõe logo a objeção, mas como diz Ésquines, deixa passar algum tempo, para ver se o expositor deseja acrescentar, modificar ou suprimir algo em seus ditos. [Plutarco, 2003, p. 13].

Ana Szpiczkowski, em seu ensaio "O silêncio, a palavra e o sábio", retoma a discussão de Plutarco sobre o mudo ouvir que leva à sabedoria, mas adverte: é preciso que o interlocutor perceba naquilo que escuta uma mensagem maior do que simplesmente um conjunto de palavras pois como afirma Bakhtin, só reagimos às colocações que despertam em nós ressonâncias ideológicas ou concernentes à vida. [Szpiczkovski, 1997, p. 34].

Silencia-se para ouvir a natureza, a interioridade e o verbo popular. Mas a silente experiência da escuta nem sempre é positiva; no caso de uma personagem de A náusea, de Sartre, o mutismo da audição tem uma repercussão impactante, gerando novo mutismo.

Roquentin vai a um bar e ali permanece até que aparece um homem que fala para a garçonete: Pobre moça. [Sartre, 2006, p. 86]. Impõe-se um silêncio diante da repercussão da frase. O homem tenta amenizar: Não é por mal. [Sartre, 2006, p. 86]. Volta o emudecer: Tudo retornou ao silêncio: mas já não é o mesmo silêncio. [Sartre, 2006, p. 86]. 
Com o silêncio, podem ser ouvidas palavras desagradáveis, portanto. É o que ocorre também com a Srta. Brill, de conto homônimo, de Katherine Mansfield. Nessa narrativa, o mutismo da escuta tem uma repercussão desastrosa: um casal afirma que sua estola parece um peixe frito. Ela fica tão perturbada que retorna para casa sem comprar o seu especial pão doce na padaria, o que fazia costumeiramente aos domingos.

A srta. Brill, antes daquele dia catastrófico, costumava ir àquela praça para ouvir uma banda de música. Tal musicalidade está presente não apenas no enredo da história, mas na sua concepção como se lê nesta explicação da autora, em seu Diário, publicado postumamente por seu esposo, Milddeton Murry: É muito estranho como a arte penetra a escrita. Refiro-me aos detalhes. Par exemple. Em "Srta. Brill", escolho não só o tamanho de cada frase, mas também o som de cada frase. Penso no ritmo de cada parágrafo de modo a se ajustar à personagem, a se adaptar a ela naquele dia, naquele momento preciso. Depois de escrito, leio o conto em voz alta, várias vezes, como se executasse novamente uma peça de música, tentando chegar cada vez mais perto da expressão da srta. Brill, até achar seu tom exato. [Mansfield, 2005, p. 272].

O narrador de "Parábolas", de Kafka, ouve uma música muda: Agora as Sereias têm uma arma ainda mais fatal do que suas canções, ou seja, o silêncio. Segundo o crítico George Steiner, os escritores modernos recorrem ao silêncio da música, tentando aproximar ao máximo a sua escrita de um canto não verbal, por causa do quadro histórico em que vivem: aguça-se no artista da palavra a noção de desgaste verbal, ocorrendo um destaque à inarticulabilidade. Para o crítico, isso se deve à noção de uma certa exaustão de recursos verbais na civilização moderna, de uma brutalização $e$ desvalorização da palavra nas culturas de massa e na política de massa contemporâneas. [Steiner, 1988, p. 66].

Cantar é ser, afirma Rilke, em "Sonetos a Orfeu". Assim, para fugir do verbo desgastado, vários autores buscam se aproximar da música, como Eliot, em Four quartets; Broch, em Der Tod des Vergil; Proust, em vários de seus escritos. [Steiner, 1988, p. 65]. 
Santiago Kovadloff afirma que entre a índole do não enunciável e a trama musical existe uma misteriosa correspondência. [Kovadloff, 2003, p. 64] e, para Vladimir Jankélévitch, a música é o silêncio audível [Jankélévitch, apud: Kovadloff, 2003, p. 69].

A música penetra no silêncio e dele se nutre. Absorve-o, assimila, o transforma e o devolve. [Kovadloff, 2003, p. 70]. E mesmo no caso de um espetáculo, os aplausos que seguem o fim da música também são uma linguagem silente: no vértice do epílogo musical, no ponto exato em que a melodia acaba de extinguir-se, ergue-se, contíguo a esse final, o aplauso. $O$ aplauso não substitui a palavra, e sim - [...] - irrompe onde a palavra ainda é inviável; e irrompe, além do mais, como manifestação acabada do efeito provocado pela experiência do silêncio extremo pela qual acabamos de passar. [Kovadloff, 2003, p. 88].

Roquentin, de $A$ náusea, só sente bem em um momento raro do romance: quando ouve, de uma vitrola, a voz de uma cantora negra entoando seu belo jazz. Ao final da audição, o silêncio: Extinguiu-se o último acorde. No breve silêncio que segue, sinto intensamente que houve algo, que alguma coisa aconteceu. Silêncio. [Sartre, 2006, p. 36].

A pausa silenciosa que está no início e no fim da execução da música pode estar no seu entremeio também, como é comum ocorrer nas composições de Beethoven, Bruckner e Wagner [Kovadlov, 2003, p.91].

A escuridão noturna faz com que os olhos descansem e os ouvidos se sensibilizem para a música, em Estorvo, de Chico Buarque. O narrador caminhando no breu, perto da fazenda da sua irmã, entrega-se à quietude da escuta: há uma música que me desnorteia o tempo inteiro. Demoro a admitir, pois nunca houve música no sítio, mas há músicas, muitas músicas ocupando todos os espaços, com a substância que a música no escuro tem. [Buarque, 1991, p. 25].

Estorvo teve adaptação de Ruy Guerra para o cinema e a sétima arte tem certos diretores muito sensíveis ao silêncio da escuta, como Ingmar Bergman. Seu filme "Saraband", de 2003, conta a história de Marianne, que se dirige ao local em que Johan, seu ex-marido, está. Ela, em vários sessões 
de quietude, ouve atenta muitas pessoas com problemas: o próprio Johan, Henrik (filho dele) e Karin (neta dele). A um dado momento da história, Henrik afirma a Marianne: Você foi muito gentil em me escutar.

A revista Vertigo em sua edição de 2006 dedicou atenção especial ao tema do silêncio no cinema ${ }^{5}$ e, em um de seus textos, Marie Anne Guerin trata do mutismo em "Saraband". A crítica afirma que o ato de ler não era silencioso, em outras eras, e passou a ser; no cinema, o espectador, [...], responde ao filme que ele vê e escuta em silêncio. [Guerin, 2006, p. 18]. Saraband, segundo Guerin, é uma película, que alterna as falas com blocos de quietude.

No início do cinema, destaca-se a quietude, já que os filmes mudos eram frugais no uso das palavras legendadas. A história chegava ao espectador pelas expressões não verbais do rosto, olhares, ações dos atores $^{6}$. Na próxima seção, serão indicados os mutismos ligados ao ver.

\section{MUDEZ NA MIRA}

No princípio estava o olho, não a palavra.

[Otto Pächt. História da arte e metodologia]

5 Devo a Mariarosaria Fabris a indicação desse periódico.

${ }^{6}$ Quando ocorre a invenção do cinema falado, há uma grande divisão entre os cineastas: alguns acreditavam que a palavra empobreceria a comunicação fílmica, como Charles Chaplin, por exemplo. 
O olhar pode, por exemplo, ser o indicativo da morte de um corpo, como mostra Laura Mulvey, no seu livro Death 24x a second: stillness and the moving image. A estudiosa mostra que em "Psicose", de Hitchcock7, a morte revela-se na personagem estática em baixo da água movente do chuveiro, mais especificamente nos seus parados olhos.

Nesse sentido, há um exemplo nacional digno de destaque; em 1965, no filme Grande sertão: veredas, adaptação dos irmãos Geraldo e Renato dos Santos Pereira para o romance de Guimarães Rosa, um dos integrantes de um bando de sertanejos, interpretado por Milton Gonçalves, é alvejado por jagunços inimigos. Ele, ao morrer nos braços de Riobaldo (Maurício do Valle), tem um close nos olhos estatelados e pétreos em contraposição aos olhos de Riobaldo que se dirigem para frente e, depois, para os lados. Nesse caso, o movimento ocular acusa a presença da vida de alguém que ao mirar sua frente se certifica da morte do outro e, ao fitar os lados, pensa nas significações e dimensões do óbito.

A imobilidade e o movimento serviram de base para um curtametragem de Roberto Santos, de 1969, no qual o foco era também Grande sertão: veredas. O filme "A João Guimarães Rosa" foi feito a partir de closes parados e moventes de fotografias de Maureen Bisiliat, mostrando o sertão brasileiro, enquanto se ouvem trechos escolhidos por Roberto da obra rosiana mencionada.

O comunicativo olhar de Maria Schell fez com que ela se tornasse a grande estrela de Noites brancas, de Luchino Visconti. Paulo Emílio Salles Gomes, em seu ensaio "Infidelidades de Visconti", observa que na viscontiana adaptação cinematográfica para a novela de Fiódor Dostoiévski, o foco das atenções sai do personagem masculino (que é também narrador no texto do autor russo) para recair, no filme, sobre a personagem feminina, Nastienka, que se torna Natália, com alto poder de silenciosa expressão em seu rosto. A atriz Maria Schell surpreendeu em sua interpretação, criando problemas ao diretor, sempre devido ao excesso e nunca à falta de expressão [...]. Paulo Emílio afirma que Visconti se propôs a valorizar ao

\footnotetext{
${ }^{7}$ Esse diretor explorou o tema do mutismo em seu filme "I confess", de 1953, traduzido no Brasil como "A tortura do silêncio".
} 
máximo os belos olhos da atriz. O título brasileiro da película, [logo que foi lançado no Brasil] "Um rosto na noite", tem sua razão de ser: durante uma hora e tanto a fisionomia de Maria Schell não nos dá trégua e é inutilmente que ansiamos por um instante de contemplação pacífica. [Gomes, 2002, p. 29].

No poema "Piedosa", de Cruz e Sousa, exalta-se o silêncio ligado ao olhar: Sinto os teus olhos fluidos, de onde emerge/ Uma graça, uma paz, tamanho encanto. Na poética do Cisne Negro, por meio da mirada do outro, pode-se avistar um tempo e um espaço diferentes:

OLHOS

A Grécia d'Arte, a estranha claridadel Daquela Grécia de beleza e graça,/ Passa, cantando, vai cantando e passa/ Dos teus olhos na eterna castidade. [...] Da Atena flórea todo o viço louro/ E as rosas e os mirtais e as pompas douro,/ Odisséias e deuses e galeras.../ Na sonolência de uma luz aziaga,/ Tudo em saudade nos teus olhos vaga,/ Canta melancolias de outras eras... [Sousa, 2000, p. 153].

Nos teus olhos tu'alma transparece..., afirma ainda Cruz e Sousa, em "Humildade secreta", em que se pode pensar que o poeta brasileiro, como bom leitor dos gregos antigos, retoma um de seus preceitos: Os olhos são as janelas da alma.

Há uma poética do olhar em Um copo de cólera: começamos a nos dizer coisas através dos olhos (essa linguagem que eu também ensinei a ela). [Nassar, 1995, p. 72]. Assim, tem-se desde o olhar de ferro [Nassar, 1995, p. 80] até o olhar piedoso [Nassar, 1995, p. 80], próximo daquele do poema "Piedosa", de Cruz e Sousa.

Mirar, em silêncio, o que fere e o que agrada é um dos temas de "Felicidade", conto de Katherine Mansfield, que está repleto de mutismos. Berta está prestes a receber, em seu lar, vários convidados: o escritor Eddie, o casal Norman Knight e Pearl Fulton, um "achado" para a dona da casa: Tinham-se conhecido no clube e Berta se apaixonara pela moça, como

8 A expressão é de Regina Lúcia Pontieri que aparece no título do seu livro: Clarice Lispector: a poética do olhar. 
sempre acontecia quando encontrava mulheres bonitas que apresentavam algo de estranho. [Mansfield, 1991, p. 13].

Em meio aos preparativos do jantar, Berta, quietamente extasiada, vê uma pereira florida, imagem que posteriormente contempla juntamente com Fulton, quase esbarrando em seus cotovelos. Depois do jantar, todos se dispersam pela casa. O escritor Eddie quer mostrar para Berta a beleza dos primeiros versos de um poema:

[...] [Berta] pôs-se a andar sem ruído para a mesa que ficava em frente à porta da sala. Eddie se esgueirou, seguindo-a em silêncio; Berta apanhou um pequeno livro e deu-o a Eddie; não produzindo o menor ruído. [Mansfield, 1991, p. 17].

O silêncio da movimentação de ambos é seguido de mais três outros silêncios: o da leitura de Eddie, o do olhar e o da escuta de Berta. Seus olhos e ouvidos se surpreendem com uma situação desestabilizadora: seu esposo, na sala, coloca as mãos nos ombros de Pearl Fulton, voltando-a para si, e diz "Eu te adoro". A convidada põe os dedos no rosto de Harry e sorri. Ele fala "Amanhã" e ela com as pálpebras responde "Sim".

Depois disso, todos se reúnem para as despedidas. Harry, então, vai fechar as portas da casa. Berta fica só, com uma frase retumbando em sua mente: aquela que Fulton pronunciou depois de ver a pereira: - como é linda a tua pereira... pereira... pereira...!

Os mutismos de certos autores muitas vezes desejam uma aproximação com a linguagem não verbal da pintura, como Manuel Bandeira, em "A maçã". Davi Arrigucci aproximou esse escrito dos quadros de Cézanne, que mostram essa fruta, afirmando: Como tantas de Cézanne, também esta maçã de Bandeira atrai e mantém cativo o olhar. É que tem o fascínio do ser que encarna o desejo - o foco da vida e da paixão numa natureza-morta. [Arrigucci, 1990, p. 25].

Segundo Davi, a proposta da natureza morta em pintura está associada à noção de interrupção do fluxo e do movimento da vida: $A$ imobilização da vida que é característica desse tipo de obra pictórica ( a vida tranqüila ou silenciosa do seu nome em alemão e inglês - Stilleben, 
still-life) tende a realçar os princípios abstratos da estrutura, a unidade formal das imagens que compõem o tema. [Arrigucci, 1990, p.27].

Assim, Bandeira aproxima a escrita da pintura, convidando o leitorobservador a imobilizar seu olhar em direção à imagem quieta que apresenta: o poeta lembra a arte de um pintor, pelo modo de ver e de compor a natureza morta [...]. O leitor desliza, por assim dizer, na direção que lhe sugere o olhar, encadeado pelo fascínio da fruta, fixada como centro da atenção em sua vida silenciosa. [Arrigucci, 1992, p. 22].

Em Um copo de cólera, o silêncio e o pictórico se encontram, mas na natureza viva: queria era o silêncio, pois estava gostando de demorar os olhos nas amoreiras de folhas novas, se destacando da paisagem pela impertinência do seu verde (bonito toda vida!) [Nassar, 1995, p.30].

Em Lavoura arcaica, também de Raduan Nassar, o narrador afirma, em certo trecho, estar traçando num quadro de silêncio, a simetria dos canteiros, a sinuosidade dos caminhos de pedra no meio da relva, [Nassar, 1982, p. 44], enfim é constatado ali um silêncio esquadrinhado em harmonia. [Nassar, 1982, p. 44].

A janela pode transformar-se na moldura de um quadro vivo, como em Mário Quintana:

A RUA DOS CATAVENTOS
Escrevo diante da janela aberta./ Minha caneta é
cor das venezianas:/ Verde! E que leves, lindas
filigranas/ Desenha o sol na página deserta!/ Não
sei que paisagista doidivanas/ Mistura os tons...
acerta... desacerta.../ Sempre em busca de nova
descoberta/ Vai colorindo as horas quotidianas.../
jogos de luz dançando na folhagem!/ Do que eu ia
escrever até me esqueço.../ Para que pensar?
Também sou da paisagem.../ Vago, volúvel no ar
fico sonhando.../ E me transmuto.../ iriso-me....
estremeço..../ Nos leves dedos que me vão
pintando.

A pintura associa-se à inarticulabilidade e essa idéia não é nova, ela já aparece no Górgias, de Platão. Para o pensador, enquanto a retórica se apresenta como a arte da palavra, a pintura a abole, sendo uma silenciosa 
manifestação da alma do artista. Mario Praz, em Literatura e artes visuais, mostra como Plutarco se impressinou com a afirmação de Simonides de Cós: a pintura é a poesia muda. [Cós, apud: Praz, 1982, p. 3].

Praz mostra que alguns estudiosos vêem profunda relação entre a pintura e a literatura, como é o caso de Hatzfeld que nota similitudes, por exemplo, entre Balzac e Renoir, bem como vê em Cézanne a perfeita encarnação das idéias de Gautier e Baudelaire acerca da arte. [Praz, 2982, p. 19].

O silencioso recurso pictórico também é usado por alguns cineastas, como Luchino Visconti. Mariarosaria Fabris, no ensaio "Fontes pictóricas de Senso", mostra que o diretor inspirou-se no universo do pintor Giovanni Fatori, entre outros, para criar algumas seqüências de "Sedução da carne" ("Senso"): O branco ofuscante da estrada e dos muros das casas, a mancha vermelha da camisa do patriota em contraste com a calça e o colete marrom de Ussoni, primo da condessa, pouco antes da batalha, são notações cromáticas que o diretor pede emprestadas a Fattori, por exemplo, [...]. [Fabris, 2002, p. 33].

"O enigma de um dia", de Giorgio de Chirico, é a "personagem" principal do filme homônimo de Joel Pizzini. Nessa película, um guarda do MASP, em que está a obra, observa a pintura e depois percorre paisagens que são seus desdobramentos. O silêncio do quadro ecoa no personagem que durante toda a fita não pronuncia uma só palavra, apenas olha para tudo com atenção, espanto e prazer.

Rilke se interessou pela linguagem silenciosa das esculturas, especialmente as de Rodin, chegando a escrever um ensaio sobre o artista. Isso não era exatamente uma novidade do século XIX, pois, segundo Mario Praz, já no século anterior, não só escritores, mas também pintores, estavam buscando sugestões em estátuas antigas, investindo pessoas modernas de atributos e qualidades tomados à História e à mitologia. [Praz, 1982, p. 5]. Além disso, Dante, já no século XIV, segundo o crítico, teria criado uma escultural Anunciação no décimo canto do Purgatório. [Praz, 1982, p. 3]. 
O silêncio é buscado, muitas vezes, para que os olhos atuem com mais precisão. Borges, citando as Confissões, de Santo Agostinho, mostra o espanto do religioso e pensador ante o modo diverso de ler de um contemporâneo seu, Santo Ambrósio: Quando Ambrósio lia, passava a vista sobre as páginas penetrando sua alma no sentido, sem proferir uma palavra nem mover a língua. [Santo Agostinho, apud: Borges, 1974, p. 714]. O ensaísta, em seguida, comenta: Aquele homem passava diretamente do signo da escritura à intuição, omitindo o signo sonoro. [Borges, 1974, p. 714]. .

Mário de Andrade, em seu artigo "Calar é ouro" ${ }^{9}$, afirma: Tenho aqui diante de mim perto de vinte volumes de poesia que percorro cuidadosamente dentro do silêncio do meu ser. [Andrade, 1993, p. 101]. Sobre esse silêncio da leitura, Alceu Amoroso Lima faz o seguinte comentário: $O$ silêncio interior se abebera em fontes humildes ou transcendentes. Abebera-se na solidão. Abebera-se na leitura. [Lima, 1955, p.64].

Mário dedicou muitas horas de silêncio e solidão à leitura, mas também costumava ler seus próprios poemas em voz alta, principalmente aqueles de seus primeiros livros, ao grupo dos artistas modernistas. No entanto, com relação aos poemas das décadas de 30 e 40 isso mudou, como mostra João Luiz Lafetá: [Em Remate de males,] Mário de Andrade realizava um balanço da sua produção poética do Modernismo, reunindo composições que mostravam desde o estilo destrutivo dos primeiros tempos até a nova forma a que chegara, os "Poemas da amiga" e os "Poemas da negra", escritos como em surdina, discretos e suaves. São os poemas de sua "fase azul" - como ele dizia -, feitos mais para serem lidos em silêncio do que para serem recitados em voz alta. [Lafetá, 2004, p. 223].

As oscilações históricas entre o ruído e a mudez com relação à leitura são estudadas por Margit Frenk, em seu livro Entre la voz y el silencio: la lectura en tiempos de Cervantes. Ela mostra que na Antigüidade, apesar de a leitura individual e quieta já ser conhecida, ler era uma atividade

9 Publicado primeiramente no periódico carioca Diário de Notícias, no dia 4 de setembro de 1939 e republicado no livro Vida literária, p. 101-106. 
destinada a uma voz que espandia o escrito a um grupo de ouvintes.

A preponderância da leitura oral sobre a silenciosa se manteve no período medieval: A cultura da Idade Média européia permanceu, em geral, sob o império da voz, como veio demonstrar de maneira definitiva o livro de Paul Zumthor, A letra e a voz: a "literatura" medieval. [Frenk, 2005, p. 17].

Frenk mostra como oscilam as leituras silentes e audíveis em $D$. Quixote, de Miguel de Cervantes, pois o Cavaleiro da Triste Figura pede a Sancho que leia escritos em voz alta e, por outro lado, D. Fernando, ao tomar um papel no peito de Lucinda, desmaiada, começa a lê-lo mudo, gerando curiosidade nos circundantes. [Frenk, 2005, p. 159-160].

Resenhando as idéias do ensaísta Mateo Alemán, Frenk mostra que, quando a leitura silenciosa passa a difundir-se mais, há uma mudança nas reações corpóreas daquele que calado lê e não mais escuta o escrito: se, antes, faziam-se presentes gargalhadas, bem como risadas nas bocas e apareciam lágrimas nos olhos, com o advento da mudez na leitura, o leitor tem manifestações contidas, quietas: o leitor oprime as reações dentro de seu corpo - "fechado", como o aposento em que lê - manifestando-se apenas com gestos silenciosos: olhos que cintilam, boca que se rasga num sorriso. [Frenk, 2005, p. 176].

Nos tempos modernos e contemporâneos, há oscilações entre o silêncio e a oralidade com relação ao ato de ler; Goethe, por exemplo, afirmou que ler em silêncio é um triste substituto da linguagem falada. [Goethe, apud: Frenk, 2005, p. 42]. Frenk mostra um estudo de Alfonso Reyes, "Categorias de la lectura", mostrando como vários autores do século XIX divergiam na opção de como ler: Théophile Gautier, [...], julga que os livros foram feitos para serem vistos e não falados. Por sua parte, Flaubert necessitava berrar sua própria prosa para ter consciência do que escrevia. [...]. Shelley, com seu auditório, lia em voz alta. [Reyes, apud: Frenk, 2005, p. 152].

Há os livros de silêncio: Jorge Luiz Borges, em seu ensaio "Del culto a los libros", mostra que a idéia do mundo como um livro não verbal está em Thomas Browne que, em 1624, afirmava: Dois são os livros em que 
consegui aprender teologia: a escritura sagrada e aquele escrito universal $e$ público que está patente a todos os olhos. [Browne, apud: Borges, 1974, p. 716].

José de Alencar, quando foi acusado de imitar Chateaubriand e Cooper, respectivamente, em Iracema e $O$ guarani, afirma, em Como e por que sou romancista, que o seu maior inspirador foi um livro mudo, pois não se compõe de palavras: a natureza nacional:

[...] o mestre que eu tive foi esta esplêndida natureza que me envolve, [...]. Daí, desse livro secular e imenso, é que eu tirei as páginas do Guarani, as de Iracema, e outras muitas que uma vida não bastaria a escrever. Daí e não das obras de Chateaubriand, e menos das de Cooper, que não eram senão a cópia do original sublime que eu havia lido com o coração.[Alencar, 1998, p. $63]$.

Mas Alencar era também apreciador de obras com verbo, como mostra Haroldo de Campos, no seu ensaio "Iracema: uma arqueografia da vanguarda": Leitor "promíscuo" (a expressão é de Araripe Jr.), Alencar leu Balzac antes de Chateaubriand e de Vitor Hugo, nos seus tentames de passar dos textos de Fénelon e Voltaire aos dos "modernos". [Campos, 1992, p.128].

Alencar recupera alguns elementos difundidos por autores do passado, mas também questiona e revisa outros. Como se viu, acusaram Iracema de imitação de Chateaubriand, especificamente do seu livro Atala. Haroldo de Campos mostra que o escritor brasileiro não leu passivamente o autor francês. A protagonista da suposta obra copiada é filha de espanhol com índia e opta por se matar a perder a virgindade com o seu amado, o índio Chacta. Isso se deve ao voto de castidade que havia feito perante a mãe moribunda. Haroldo afirma: Com Iracema, tudo se dá com sinal trocado. A virgem de Tupã viola o interdito da tribo e se deixa possuir por Martim, possibilitando que este lhe arrebate o licor sagrado da jurema, com o qual o jovem guerreiro português se "droga" $e$, assim, amortece as restrições de seu código de conduta cavalheiresco e cristão. [Campos, 1992, 
p. 133].

Para Campos, diferentemente de Atala, Iracema é figura feminina capaz de iniciativa amorosa e realização sexual, em lugar de uma submissa e obstinada pucela freirática. [Campos, 1992, p. 133]. Alencar, com as suas leituras dos autores portugueses, contribui para revisar a imagem do índio nos escritos brasileiros. O autor de $O$ guarani deu voz aos silenciados índigenas, apesar de idealizá-los demais; no entanto, a empreitada é válida se se pensa que os lusitanos, em seus textos, faziam o contrário, ou seja, tentavam diminuí-los: Caminha afirmou que eles deviam ser salvos imediatamente; Gândavo entendeu que o que falavam não devia ser considerado como língua; para vários outros autores, eles não tinham alma e deviam ser considerados como animais.

A noção crítica de que muitos índios das Américas foram silenciados pelo extermínio criminoso dos europeus está em Como e por que sou romancista:

O Brasil tem, como os Estados Unidos, $e$ quaisquer outros povos da América, um período de conquista, em que a raça invasora destrói a raça indígena. Essa luta apresenta um caráter análogo, pela semelhança dos aborígines. Só no Peru e México difere. Assim, o romancista brasileiro que buscar o assunto do seu drama nesse período da invasão não pode escapar ao ponto de contato com o escritor americano. Mas essa aproximação vem da história, é fatal, e não resulta de uma imitação.

Em Iracema, o pai da protagonista, identifica no canto da coruja um aviso de que algo horrível está por acontecer, quando Martin entra pela primeira vez nas imediações em que ficava a sua oca. Talvez seja a futura morte de sua filha, acarretada pelo branco intruso.

Se os personagens de Iracema têm o ouvido fino, o mesmo se pode dizer de seu autor, que segundo Haroldo de Campos, dispôs-se, nessa obra, a tupinizar o português. [Campos, 1992, p. 133]. A voz indígena, silenciada 
pela escrita dos brancos, está dentro de um contexto do silêncio político, estudado por Eni Orlandi: [há] um campo fértil [desse mutismo] para ser observado: na relação entre índios e brancos, na fala sobre a reforma agrária, nos discursos sobre a mulher. [Orlandi, 1995, 30-31].

Segundo Haroldo, é possível ouvir a voz indígena em Iracema, que é um livro polifônico, já que vozes de outros autores podem ser ouvidas, em meio a anagramas, metáforas, jogos de linguagem que são bastante revolucionários para a linguagem contemporânea a Alencar.

Alencar se dispõe a ouvir os indígenas e, assim, acaba inovando a língua nacional, buscando justamente sua faceta mítica e atávica. Por causa desse processo e pelas invenções de palavras, o autor cearense recebe o seguinte comentário de Silviano Santiago:

Bem antes de Mário de Andrade e de Guimarães Rosa, Alencar foi o prosador que mais contribuiu para o enriquecimento do dicionário brasileiro da língua portuguesa. [Santiago, 2001, p. 13].

O crítico comenta que depois da publicação do livro clássico de 1865, muitas crianças brasileiras, que recebiam até então nomes de santas e santos, passam a ser batizadas de Iracema e Moacir, graças à invenção alencariana. [Santiago, 2001, p. 15].

Em uma nota de seu livro, Alencar explica que ira, em guarani, é mel e cembe/tembe é lábios; o autor cearense aportuguesou a união das duas palavras tupis, resultando em Iracema. Esse nome também é anagrama de América. Moacir, o filho de Iracema e Martim, é nome tupi que significa filho da dor.

Em Ubirajara, definido por Alencar como um livro irmão de Iracema, o protagonista muda duas vezes de nome: primeiro é Jaguarê, quando tem a função de caçador; quando torna-se um guerreiro, passa a ser chamado de Ubirajara. Quando visita uma outra tribo e escolhe a índia Aracy como esposa, passa a ser Jurandir. Antes de esse nome ser definido, pelo protagonista, vários outros são cogitados, pelos integrantes da tribo visitada: Jutaí, Boitatá, Caraúba e Jutorib ${ }^{10}$.

10 Esse argumento do livro de Alencar foi inspirado nas suas leituras de pesquisadores dos 
Em Iracema, o autor cearense parece discutir a idéia da necessidade da criação de inéditos nomes para designar especificidades brasileiras como a dos relacionamentos entre portugueses e índios. Sugerindo a idéia de limite da linguagem corrente, a expressão de Alencar torna-se um híbrido entre o tupi e o português para comunicar um contexto de experiências nacionais a partir da chegada dos portugueses ao nosso país.

Ubirajara e Iracema são livros repletos de notas de rodapé do autor, que se propõem a esclarecer situações, termos e outros elementos do discurso fictício que podem parecer obscuros para o leitor. O autor cearense, do século XIX, apresenta em sua obra um conteúdo relativamente compreensível à primeira leitura, diferentemente do que fazem muitos autores dos séculos $\mathrm{XX}$, com seus textos sem explicações e plenos de obscuridade.

É o silêncio ligado ao hermetismo, que, para Adorno, é um reflexo de momentos históricos nos quais o artista não quer que sua arte se torne fácil, como um produto de consumo. Modesto Carone, em A poética do silêncio, tomando esse pressuposto adorniano, observou que a inarticulabilidade de cunho hermético está presente na obra de Paul Celan, comparando-a com a de João Cabral de Melo Neto. Para o crítico, há uma dicção poética fechada [Carone, 1979, p. 17] em Celan, enquanto, em João Cabral, desponta $o$ verbo solar [Carone, 1979, p. 17], já que o autor nordestino busca uma didática da natureza, perseguindo, inclusive, a mudez das pedras e o vazio ligado à secura do sertão.

Haveria, então, um parentesco entre os textos de Celan e o de Franz Kafka. Albert Camus faz o seguinte comentário a respeito dos escritos do autor tcheko:

índios, como Hans Staden, citado nesta nota de Ubirajara: Mal nascia a criança logo se lhe punha nome. Hans Staden achou-se presente numa dessas ocasiões. Convocou o pai aos mais próximos vizinhos de dormitório, pedindo-lhes para o filho um nome viril $e$ terrível: não lhe agradando nenhum dos propostos, declarou que ia escolher o de um de seus quatro antepassados, o que daria fortuna ao rapaz, e repetindo-o em voz alta o mancebo que aos seus títulos ia acrescentando um por inimigo que trazia para casa a ser imolado. Também a mulher tomava adicional apelido quando o marido dava uma festa antropófaga. De objetos visíveis se tirava o cognome, determinando o orgulho ou a ferocidade a escolha. [Alencar, 1980, 13-14]. 
Toda a arte de Kafka consiste em obrigar o leitor a reler. Os desfechos de suas histórias - ou sua falta de desfecho - sugerem certas explicações, mas estas nunca são claras o suficiente. Somos pois obrigados a reler suas histórias de um novo ângulo do qual estas explicações podem parecer melhor justificadas. Algumas vezes há uma dupla ou tríplice possibilidade de interpretação, daí a necessidade de duas ou três leituras. [Camus, apud: Barbosa, p. 61-62].

O estorvo, de Chico Buarque, pede releituras, porque está pleno de silêncios do subtexto. O narrador da história tem um amigo que é poeta e, ao se manifestar, os outros mal o ouviam, olhavam-no com a fisionomia embaçada. [Buarque, 1991, p. 42]. É que ele preferia mesmo dizer coisas que os outros só pudessem compreender anos depois. [Buarque, 1991, p. $42]$.

Assim, o discurso poético desse personagem não atinge imediatamente seus interlocutores, pois é preciso analisá-lo com vagar, escavando-o a partir de sua superfície para encontrar seus significados mais profundos.

O narrador conta que esse seu amigo inventou uma nova língua, chamada desesperanto, e que, quando falava português, muitas pausas entrecortavam seu discurso. Tais pausas podem ser lidas como lacunas semânticas que pedem a complementação do ouvinte. O próprio romance é assim: pleno de espaços em branco, deixados à disposição de quem lê para sua complementação com palavras, interpretações.

O filósofo Sciacca afirma: Aquilo que eu escrevo parte do silêncio intraduzível e retorna, como palavra, no silêncio de quem está lendo, fermentando palavras novas diferentes das minhas. [Sciacca, p. 30].

O dizer silencioso que se faz no intervalo é comentado por Orlandi: $O$ silêncio é a "respiração" (o fôlego) da significação; um lugar de recuo necessário para que se possa significar, para que o sentido faça sentido. [Orlandi, 1995, p. 13]. 
Eni afirma que esse silêncio lacunar ou elíptico ocorre com muita freqüência em tempos de censura política. A estudiosa mostra que, para fazer uma crítica ao regime ditatorial e militar brasileiro, os artistas serviram-se do não-dito, do implícito, como J. J. Veiga, em Sombras de Reis Barbudos, já que, com sutileza, a atmosfera dos tempos da ditadura é referida na separação entre os homens por meio de muros que se erguem. A arbitrariedade dos governantes e a sua constante ameaça são metaforizadas, no romance, pela proibição de plantio de legumes no quintal. [Orlandi, 1995, 118-119]. A crítica observa que técnicas parecidas são usadas por Chico Buarque nas suas letras de músicas desse período.

Com relação ao célebre músico, isso foi reiterado por Adélia Bezerra de Meneses, em Desenho mágico: poesia e política em Chico Buarque. Nesse estudo, a crítica observa que a palavra cálice da famosa canção desse compositor, em parceria com Gilberto Gil, pode ser ouvida como cale-se e aponta os possíveis sentidos desse mutismo: Evidentemente, num primeiro nível, uma decodificação político-social do poema se impõe, e é cristalina: trata-se do silêncio imposto, da Censura do Governo Médici (o poema é de 73) que silencia a voz do poeta. Mas não apenas a ela: o arbítrio da representação silencia - no limite com o silêncio definitivo da morte - todos aqueles que ousassem falar. [Meneses, 1982, p. 95].

Adélia compara esse mutismo que se afigura, conforme a letra de Chico, como o monstro da lagoa, com as imagens de um conto de Edgar Alan Poe chamado "O silêncio". Nele, o narrador afirma que o demônio uma vez contou-lhe uma de suas experiências: estava às margens do rio Zaire, na Líbia, quando viu gravada num rochedo a palavra DESOLAÇÃO. Desceu para o pântano e viu um homem que impôs a "maldição do tumulto" a todos os elementos da natureza que começaram a emitir altos ruídos. Em seguida, irritado, aquele homem lançou a "maldição do silêncio" e as letras do rochedo mudaram para SILÊNCIO. O final se dá com estas palavras do demônio: $E$ o homem estremeceu, voltou o rosto e pôs-se em fuga, precipitadamente; e nunca mais o tornei a ver. [Poe, apud: Meneses, 1982, p. 98]. 
À escrita de Chico Buarque adequam-se as palavras de Roland Barthes, em "Escrever a leitura": Ao ler, nós também imprimimos certa postura ao texto, e é por isso que ele é vivo. Ou seja, o teórico francês se refere ao vívido dinamismo de alguns textos que convidam o leitor a participar da sua construção semântica.

A idéia do livro vivo já havia sido divulgada anteriormente por John Milton, mas num outro sentido: Livros não são coisas absolutamente mortas: contém um espécie de vida em potência tão prolífica quanto a da alma que os engendrou. E mais: eles preservam, como num frasco, o mais puro e eficaz extrato do intelecto que os produziu.

A potência da leitura é comentada por vários escritores que manifestam a sua paixão pelos $\operatorname{livros}^{11}$; Carlos Drummond, por exemplo, refere-se a eles como amigos, na crônica "O sebo": Para onde foram os livros usados, os que tinham na capa esse visgo publicitário, as brochuras encardidas, as encadernações de pobre, os folhetos, as revistas do tempo de Rodrigues Alves? Tudo isso também é gente, na cidade das letras, [...]. Vem para a minha estante, Marcelo Gama, amigo velho, ou antes, volta para ela, de onde não devias ter saído ${ }^{12}$.

Marcel Proust, em Sobre a leitura, também menciona esses companheiros que se dispõem em estantes, mas aponta uma diferença entre os amigos de papel e tinta com relação aos de carne e osso: Esses amigos [os livros], se passamos a noite com eles, será porque realmente temos vontade de fazê-lo. Não os deixamos, pelo menos estes, senão com remorso.

Os olhos servem para ler livros ou corpos. A silenciosa comunicação facial, por exemplo, foi alvo de estudo do Abade Dinouart, no século XVIII,

11 Título de uma obra que coleta depoimentos, crônicas, poemas e outros tipos de textos nos quais seus autores mostram sua afeição pelo ato de ler.

12 A "paixão pelos livros" se deixa ver/ler em um outro texto de Drummond, a "Biblioteca verde": Papai, me compra a Biblioteca Internacional de/ Obras Célebres./São só 24 volumes encadernados/ em percalina verde./ Meu filho, é livro demais para uma criança./ Compra assim mesmo, pai, eu cresço logo./ [...]/ Rio de Janeiro? Aqui é o Coronel./ Me mande urgente sua Biblioteca/ bem acondicionada, não quero defeito.[...]/ Segue a Biblioteca pelo trem-de-ferro,/ fino caixote de alumínio e pinho./ [...]./ Chega cheirando a papel novo, mata de pinheiros toda verde. / [...] leio, leio. Em filosofias/ tropeço e caio, cavalgo de novo meu verde livro, em cavalarias/ me perco, medievo; em contos, poemas me vejo viver. Como te devoro, verde pastagem. Ou antes carruagem/de fugir de mim e me trazer de volta à casa a qualquer hora num fechar de páginas/[...]. [“Biblioteca verde”, de Carlos Drummond de Andrade]. 
em seu texto, A eloqüência do corpo. O estudioso afirma: [os mais ignorantes] reconhecem no rosto a devoção, a dissipação, a alegria, a tristeza, a cólera, a compaixão. ${ }^{13}$

Assim, a face pode, sem a palavra, expressar-se, como se nota nesta passagem de Lavoura arcaica: que rostos mais coalhados, nossos rostos adolescentes em volta daquela mesa [Nassar, 1982, p. 41].

As mãos, também, no seu silêncio, manifestam sentidos, como mostra Michele Federico Sciacca, em seu livro Linguagem e silêncio: Um gesto das mãos seguidamente traduz melhor a plenitude silenciosa de nossa interioridade. [Sciacca, 1966, p. 39].

Em Lavoura arcaica, aparecem as mãos terníssimas [Nassar, 1982, p. 58] ou as mãos entregues a um gesto fúnebre [Nassar, p.125] ou empenhadas em um gesto de reprimenda [Nassar, 1982, p. 41]. Essa parte do corpo manifesta o estado de espírito do seu portador: Sua mão [do irmão do narrador] [...] se retraindo calada e pressurosa, era a mão assustada da família saída da mesa dos sermões. [Nassar, 1982, p. 41].

Essa obra de Raduan Nassar e também Um copo de cólera tiveram adaptações cinematográficas. No caso de Um copo de cólera, a proximidade do discurso dos personagens com a linguagem fílmica é mencionada por eles próprios: enxotado pela consciência coletiva, que jamais tolera o fraco, você só tinha de morar no mato; [...], só podia ser este o teu 'destino': viver num esconderijo com alguém da tua espécie - Lúcifer e seu cão hidrófobo... que pode até dar fita de cinema... há-há-há... [Nassar, 1995, p. 64].

Outros sentidos são possíveis para os muitos silêncios e alguns deles foram percebidos na obra de Manoel de Barros, se bem que por pouquíssimos críticos, como será visto na próxima seção.

13 [Dinouart, L'éloquence du corps, p. 22. Apud: Courtine, Jean-Jacques \& Haroche, Claudine. "Apresentação", In Dinouart, 2001, p. XXVII]. 


\title{
LEITORES DO GUARDADOR DE ÁGUAS E DE CALARES
}

\author{
Vale ressaltar, [...], a coerência vigorosa \\ e serena da palavra de Manoel de Barros, \\ nascida em contacto com a paisagem \\ e o homem do Pantanal. \\ [Alfredo Bosi, História concisa \\ da literatura brasileira].
}

Marcelo Marinho, em “Cinema e literatura: o Pantanal como metáfora da arte em Joel Pizzini e Manoel de Barros" destaca a inarticulabilidade de uma cena do filme "Caramujo-flor", de Pizzini, que é uma adaptação cinematográfica de vários poemas manoelinos:

O silêncio, imagem acústica do indizível, do incognoscível, vela com zelo de amante os mistérios do universo, como já anunciava a fórmula vertiginosa de Hamlet: "o resto é silêncio". Assim, em Pizzini, uma harpa mergulhada pela metade nas águas da Gruta do Lago Azul (Bonito) é dedilhada pelas mãos de "Ney" [Matogrosso], gesto que resulta em silêncio: arte e natureza sonegam na vertigem do vazio. (Marinho, 2003, p. 88).

Alguns críticos perceberam o parentesco dos escritos manoelinos com 
o cinema, como Kati Eliana Caetano e Rita Baltar Van der Laan, que em "A iconização e a construção ideológica da realidade", afirmam: Na verdade, a construção da natureza deriva de um processo semiótico de utilização de figuras relativas a conteúdos do mundo significante combinadas como formas de um mosaico. São animais, vegetais e objetos captados pelo olhar dirigido em "zoom" de um observador atento, que os conjuga em amontoados aparentes de percepções. Esse procedimento lingüístico, equivalente à sintaxe fílmica, é possível pela instalação exaustiva de figuras que recobrem todo o enunciado. [Uetabano \& Van der Laan, 1995, p. 6].

O crítico de cinema José Carlos Avelar começa seu ensaio "O chão da palavra: cinema e literatura no Brasil” com a definição de poesia de Manoel de Barros, do livro Arranjos para assobio: uma armação de objetos lúdicos com emprego de palavras, imagens cores, sons, etc., geralmente feitos por crianças, pessoas esquisitas, loucos e bêbados" [Barros, apud: Avelar, 1994, p. 91].

Avelar mostra, ao longo de seu ensaio, o tema das adaptações cinematográficas de textos literários. Barros é amplamente citado, já que o crítico recolheu passagens da obra manoelina em que o poeta discorre sobre a sua arte como aquela de quem vive a criar imagens.

José Fernandes, no seu livro A loucura das palavras, publicado em 1987, afirma: Interessam-lhe [a Barros] os significados recônditos, encontrados além das margens dicionárias. Aqueles significados obtidos pelas combinações dos vocábulos com elementos extraverbais, como o espaço em branco, ou aqueles que permanecem no silêncio. Os mais eloqüentes, por sinal. Deste modo as palavras assinalam os significados, apontam-nos, mas não os dizem, conservando a mensagem no indizível. [Fernandes, apud: Castro, 1992, p. 65-66].

Mas, apesar de esse trecho apontar para o silêncio, o interesse de José Fernandes é na palavra de Barros: Todas as coisas podem ser poéticas, desde que, ao se transformarem em palavras seus significados referenciais cedam lugar ao poético. (Fernandes, apud: Castro, 1992, p. 66). 
Se o silêncio não ocupa a atenção central dos críticos, seria importante, então, apresentar quais os outros temas que interessaram a maior parte da crítica.

Os escritos manoelinos, na maioria das vezes, eram ignorados tanto pelo público leitor, quanto pela crítica. Há cerca de dezesseis anos isso mudou e o interesse sobre os textos do autor vem crescendo sensivelmente.

No período de relativo anonimato, Barros tinha um público leitor especial. O crítico e filólogo Antônio Houaiss, por exemplo, já o lia:

Meu entusiasmo em relação a Manoel de Barros não é de hoje. Vem desde o seu primeiro livro.[...]. [Barros é] um visionário da humildade $e$ da solidariedade humanas, capaz de oferecer um tratamento da matéria poética de tal maneira que um musgo, um caramujo e uma estrela tenham o mesmo valor hierárquico. [Antônio Houaiss, apud: Fagá, 1989, p. 73.].

Alfredo Bosi, em sua História concisa da literatura brasileira, não deixa de mencionar Manoel de Barros como um nome de destaque da poesia brasileira de qualidade, como se pode ler no trecho que aparece como epígrafe desta seção.

Millôr Fernandes, em 1990, mostra-se indignado com a indiferença da mídia da época com relação aos escritos manoelinos: É poesia única, inaugural, apogeu do chão. [Millôr Fernandes, apud: Fraga, s. d.]. Millôr foi um importante divulgador dos textos do poeta, publicando-os na Revista Veja e, posteriorente, no Jornal do Brasil.

O humor, que é típico dos textos e desenhos de Millôr, está presente também na obra manoelina, o que foi notado por Maria Adélia Menegazzo, em "Desvio e humor em Manoel de Barros". Em um preâmbulo, a crítica explica o que seria desvio, baseando-se no livro Retórica geral, de J. Dubois e outros autores: Os desvios retóricos [...] são aqueles que visam a efeitos poéticos e são imprevistos e imprevisíveis. [Menegazzo, 2000, p. 663].

Assim, a crítica mostra como Barros toma uma expressão extremamente conhecida e convencional para desviá-la, como, por exemplo, sem eira nem beira que se torna sem eira nem vaca e amarrar cachorro 
com lingüiça que passa a ser desamarrar cachorro com lingüiça [Menegazzo, 2000, p.664-665].

O humor manoelino também chamou a atenção do crítico Clóvis de Assumpção, em seu livro Manoel de Barros: conferência crítica, no qual afirma: Sobre Manoel de Barros quero registrar o humorismo como uma das inovações do Modernismo na sua poética. Manoel de Barros está livre do mal do seriessismo. Jamais fechou a cara deliberadamente, porque sabe abrir o coração. O humorismo, no caso histórico, era necessidade opremente da própria poesia brasileira. [Clóvis Assumpção, apud: Fraga, s. d.].

Alex Fraga, em seu artigo "Manoel de Barros aos olhos da crítica", observa a recepção dos escritos manoelinos entre os críticos do Brasil. Além de apontar o estudo de Clóvis de Assumpção, do Rio Grande do Sul, o jornalista indica os leitores da região de origem do poeta, Centro-oeste, comentando sobre o lançamento de um livro publicado pela editora da Universidade Federal de Mato Grosso, o já mencionado A loucura das palavras, de José Fernandes e a tese "Ruptura lingüística na poética sulmatogrossense", de Albana Xavier Nogueira e Waldomiro Vallezi ${ }^{14}$.

A região Sudeste apresentava um número maior de admiradores do escritor cuiabano como mostra a lista feita por Fraga: o escritor Ênio Silveira, o jornalista José Hamilton Ribeiro, o crítico e jornalista José Maria Cançado, a cantora Fernanda Abreu, o compositor e teatrólogo Geraldo Carneiro e o poeta Chacal. [Fraga, s. d., p. 12].

Geraldo Carneiro e Chacal participaram do filme "Caramujo-flor", de Joel Pizzini, da década de oitenta. Em 2005, o mesmo Pizzini lança o filme "500 ALMAS", documentário sobre os índios Guatós, de Mato Grosso do Sul, no qual Manoel de Barros faz declarações a respeito deles e lê um poema de $O$ livro das ignorãças.

14 Essa lista pode ser atualizada com a inclusão do nome da cantora e compositora Ana Carolina que, na faixa "Notícias populares", do seu CD "Dois quartos", lançado em 2006, canta: Tudo se acaba, olha o noticiário/ Água se acaba, se acaba a prece do vigário/ Eu quero ser a mendiga suja e descabelada/ Dormindo na vertical/ E entender como a vida de alguém se acaba antes do final/ Prefiro Lou Reed no Velvet Underground; gosto de Sylvia Plath, T. S. Eliot, Emily Dickinson, Lucinda, Adélia, Manoel de Barros/ Serão eternos pra mim. [Ana Carolina]. 
Entre um filme e o outro, houve um considerável aumento de interesse pelos escritos de Barros, pois se até o final dos anos 80, época de "Caramujo-flor", os leitores eram poucos e eram escritos escassos artigos de jornal ou revista sobre o poeta, isso muda a partir da década seguinte, e da posterior (quando é lançado “500 almas”), pois o público leitor aumenta e surgem não só artigos na imprensa como também ensaios mais detidos sobre a obra do autor; além disso, aumenta consideravelmente o número de dissertações e teses sobre ele.

Esse recente, mas expressivo, interesse sobre o poeta, verificado na produção crítica sobre sua obra, pode ser constatado em uma Dissertação de Mestrado, voltada para a recepção da sua obra: $O$ inventário bibliográfico sobre Manoel de Barros, de Walquíria Gonçalves Béda, defendida em 2002, na UNESP, campus de Assis. O trabalho é dividido em duas partes, na primeira aparecem resenhas de Walquíria a partir dos textos sobre Barros e, na seguinte, são anexados os ensaios e as entrevistas mais representativos.

Há, também, leitores de Barros no exterior, como os franceses, pois alguns de seus poemas foram lançados em uma coletânea, organizada por Renata Pallottini, que assina a introdução, na qual afirma: Le poéte, née en 1916, reste fidèle à la beauté de sa terre natale et écrit une poésie originale, tellurique, pleine de souvenirs de ses fleuves et de son peuple. ${ }^{15}$

A revista francesa Infos Brésil publicou o artigo "L'exercice poétique de l'innocence", no qual se lê: Les poèmes de Manoel de Barros sèduisent dès la première lecture par leur fraîcheur, leur candeur, leur noveauté. [...]. Ses poèmes sont extrêmement travaillés, polis même dans leur apparent spontanéité. [INFOS BRÉSIL, apud: Castro, 1992, p. 61-62].

$O$ livro das ignorãças foi traduzido para o francês, o que foi comentado pelo seu autor: "La Parole sans limites" está bem traduzida. Gostei. Virei um cuiabano em Paris. [Barros, apud: Alves, 2003].

Na Itália, Ana Thereza Vieira publicou uma coletânea de poemas de autores brasileiros contemporâneos, que ela traduziu para o latim. O título

15 Pallottini, Renata. Anthologie de la poésie brésilienne. Tradução: Isabel Meirelles. Édition bilingue. Paris, editions Chandeigne, 1998, p. 343, apud: Vasconcelos, 2002, p. 8. 
do livro é Rotae temporis e entre os autores incluídos estão Adélia Prado, Ferreira Gullar e outros. A tradutora escolheu, de Manoel de Barros, um trecho do livro Poesias, intitulado "Fragmentos de canções e poemas", que passou a ser "Fragmentis canticorum et carminum". Cito dois trechos em que aparece o silêncio:

[...]. Aperta/ sum, ut nocturna folia,/ ad astra. Os meum taciturnum.

[Aberta estou, com pétalas, noturnas, para os astros. Minha boca silenciosa]. [Barros, apud: Vieira, 2001, p.74-75].

Sunt mille res non auguratae/ quae me audiunt:/ motus foliorum/ silentium und redis/ et lux quae corpus nascens dividit.

[São mil coisas impressentidas/ que me escutam: o movimento das folhas/ o silêncio de onde acabas de votar e a luz que divide o corpo do nascente]. [Barros, apud: Vieira, 2001, p. 80-81].

Vários poemas de Barros e uma entrevista com ele foram publicados na revista El paseante, da Espanha, em 1989. A edição era dedicada à Literatura Brasileira e, ao lado dos escritos manoelinos, estavam os textos de Clarice Lispector, Rubem Fonseca e outros.

No Brasil, a mídia, a partir da década de 90, passou a publicar entrevistas com o poeta, principalmente a Folha de São Paulo. Vânia Maria de Vasconcelos, em sua tese de doutorado "A poética 'in-verso' de Manoel de Barros: metalinguagem e paradoxo representados numa 'disfunção lírica' ", defendida na PUC-SP em 2002, analisa várias entrevistas de Barros e nota que o poeta assume à revista Cult que sua poesia apresenta certa complexidade e que o leitor precisa ter enleios para acompanhar as curvas e enroladas dos versos. A própria Vânia entrevista Barros e pergunta se há obscuridade e hermetismo em sua obra. O autor confirma: Acho que sou um pouco difícil porque sempre compareço aos meus desencontros. Quem comparece aos desencontros acaba em paradoxos. [...]. Vou mais pelo que as palavras tocam pelo que elas dizem. Assim eu fico mais obscuro, né? Pois o escuro me ilumina. [Barros, apud: Vasconcelos, 2002, p. 148]. 
Também da PUC e analisando as entrevistas de Barros, Julio Neves Pereira, em sua Dissertação de Mestrado Como poetam os poetas?, nota, nos depoimentos do autor cuiabano, que a sua produção textual se pauta na reescrita e que seus textos são opacos e desreferencializadores, havendo também, por parte do autor uma preocupação com a sonoridade das palavras.

Além da sonoridade, a visualidade é alvo de atenção de Barros, que tem não só ouvidos finos mas também um olhar agudo, de quem não só vê profundamente textos, mas também pinturas. Maria Adélia Menegazzo, na seção "Manoel de Barros: o chão é um ensino", do seu livro A alquimia do verbo e das tintas, mostra as bases pictóricas que inspiraram o poeta, como o surrealismo em Compêndio para uso dos pássaros e a técnica cubista da "collage" ou montagem, em Gramática expositiva do chão.

Menegazzo compara o escritor cuiabano com o pintor Paul Klee, afirmando que ambos trabalham a livre fantasia e a intuição. Para comprovar isso, a estudiosa afirma que há coincidências entre "A máquina de chilrear", de Klee, e o poema "A máquina de chilrear em seu uso doméstico", de Barros.

Muitas comparações foram feitas entre Manoel e outros escritores.

Um contraste entre a poética de Alberto Caeiro e a do escritor cuiabano foi feito por Isaac Newton Almeida Ramos, em sua Dissertação de Mestrado intitulada Uma poética da modernidade: leitura comparativa entre Alberto Caeiro e Manoel de Barros, defendida na Universidade de São Paulo em 2002.

Isaac observa mais as similitudes do que as diferenças entre os dois autores, montando, inclusive, na última parte do estudo, um "diálogo" entre Caeiro e Barros, do qual cito uma passagem:

CAEIRO: Procuro despir-me do que aprendi. [Obra poética: $251,226]$.

BARROS: Desaprender 8 horas por dia ensina os princípios. [ livro das ignorãças: 11]. 
Flávio Aguiar comparou Barros com Carlos Drummond de Andrade:

Há - [...] - umas pinceladas de Drummond em sua poesia. [...]. Só que num estilo muito pessoal, mais espraiado e menos contido do que o do mineiro. Mas ambos compartilham de uma mesma certeza, cheia de dúvidas: a de fazerem poesia a partir da visão bruta das coisas, buscando nelas os sinais de alguma humanidade - perdida ou por encontrar num mundo de coisas cada vez mais coisas $e$ felizes em serem só coisas. [Aguiar, 1999, 34].

Rogério Eduardo Alves, em vários trechos da sua Dissertação de Mestrado, faz relações entre a obra de Barros e a de Drummond, como Aguiar; no entanto, sempre deprecia a obra do poeta cuiabano. Rogério tenta relacionar a obra manoelina com a biografia do autor, atendo-se especificamente ao fato de ele ser fazendeiro, o que inspira, inclusive o título do seu trabalho: Manoel de Barros, o poeta fazendeiro. O resultado é problemático, pois é como se esse dado biográfico trouxesse todas as respostas para os enigmas da poesia de Barros; além disso, a obra manoelina é malbaratada sem haver ao menos uma análise com profundidade de seus poemas.

Barros é bastante comparado com outro escritor mineiro: João Guimarães Rosa.

Magda Martins Magalhães e Marcelo Marinho, em "A brasilidade em Manoel de Barros e Guimarães Rosa: do regional ao universal”, mostram as habilidades dos dois escritores em inserir a fala popular na literatura, aproveitando inclusive os traços regionais de humor. Outra coincidência: Em Barros e Rosa, as palavras, além da sua sugestiva e musical sonoridade, trazem consigo significados pouco precisos e jamais unívocos, significados dúbios ou plurivalentes, ausentes dos dicionários. [Magalhães \& Marinho, 2002, p. 64].

Hygia Therezinha Clamon Ferreira, em texto-orelha, nas últimas edições de Compêndio para uso dos pássaros, ressalta os silêncios de ambos os autores: [...]. Já se viu que Manoel de Barros é um Iniciado e, talvez por isso, defina a poesia como "os silêncios sem poro". E aqui a 
mesma voz o reaproxima do Rosa, pela boca de Massacongo, para quem certas coisas são "assunto dos silêncios". [Ferreira, na orelha de CUP].

Em "Manoel de Barros e Guimarães Rosa: o avesso do avesso", Igor Rossoni - depois de apontar várias coincidências ligadas ao mútuo desejo dos escritores de romper com os limites das palavras - mostra elementos que diferenciam suas escritas: o saber mítico dos gerais [Rossoni, 2003, p. 56], em Rosa, e o saber aquoso e fértil das primeiras rastejações [Rossoni, 2003, p. 56], em Barros, o destaque para o jagunço, nos escritos rosianos, e o foco sobre o bugre, nos textos manoelinos ${ }^{16}$.

Outro crítico que aponta diferenças entre Barros e Rosa é Luiz Henrique Barbosa, no seu livro Palavras do chão: um olhar sobre a linguagem adâmica em Manoel de Barros:

Creio que há em Barros um interesse que não verificamos na obra de Rosa: a vontade de chegar ao grau zero de uma palavra. Há, em sua poesia, a encenação da busca de uma linguagem adâmica que esteja mais próxima às coisas. Sua poesia parece surgir em função desse interesse pela origem da língua, ou pelo antes da língua. [Barbosa, 2003, p. 18].

O termo adâmico utilizado pelo pesquisador nessa citação e que entra no título de seu livro é explicado: ele vem de Haroldo de Campos, quando discute o conceito benjaminiano de língua pura. O crítico brasileiro, interpretando o pensador alemão, diz que a língua é pura quando está em estado de primeiridade icônica, auroral. [Campos, apud: Barbosa, 2003, p. 19].

Haroldo é comparado com Barros em um trecho da Tese de Doutorado de Mônica Pinto Rodrigues da Costa, intitulada Nova Poesia Brasileira: 10 poetas, defendida em 1997, na PUC, de São Paulo. A estudiosa afirma que ambos os escritores têm a tendência barroca de buscar metáforas raras. A

16 Pode-se pensar em uma outra diferença entre os escritores: no imaginário místico rosiano, influenciado por várias crenças, entra a referência ao diabo, enquanto na obra manoelina esse termo só aparece na forma de substantivo composto: pobre-diabo. 
diferença entre eles é também apresentada: Enquanto a poesia de Barros é feita de coisas em estado de natureza, a de Haroldo de Campos pesquisa galáxias cristalinas. [Costa, 1997, p. 163].

Giovanni Ricciardi, no ensaio "A lesma e o Pau-mulato: dois projetos para uso da natureza", associa Barros ao escritor paraense Benedito Monteiro, no sentido de que ambos têm a noção de desgaste da palavra e que para renovar a linguagem é preciso inserir na escrita, respectivamente, a fala do pantaneiro e o dizer do homem amazônico.

Kelcilene Grácia da Silva, em um trecho da sua dissertação A poética de Manoel de Barros: um jeito de olhar o mundo, defendida na UNESP, campus de Assis, compara o autor cuiabano com Oswald de Andrade: $A$ poesia do autor de Poemas concebidos sem pecado apresenta pontos de convergência com a radicalidade poética de Oswald de Andrade: um olhar voltado para as insignificâncias, que se tornam elementos de uma grande poesia. [Kelcilene, 1998, p. 131].

Lúcia Castello Branco, em "O mais sublime dos meninos", entende que a coisa do livro manoelino Retrato do artista quando coisa teria alguma relação com a das Ding, de Heidegger. Lúcia cita um trecho de $A$ origem da obra de arte, do filósofo alemão:

Não deve então a obra, por seu lado, $e$ precisamente, antes do seu ser-criada, e em vista deste, inserir-se numa relação com as coisas da terra, com a Natureza, para que ela possa adequadamente pôr no aberto, o caráter coisal? Alguém, que o deveria saber, Albrecht Dürer, diz aquelas palavras conhecidas: "Pois, na verdade, a arte está na Natureza, e quem daí a consegue arrancar, possui-a.". [Heidegger, 1989, p. 56. Apud: Castello Branco, 1998, p. 67].

Segundo Lúcia, nesse caso, trata-se, já o demonstrou Lacan, da "elevação de um objeto à dignidade da Coisa". Assim, a crítica conclui que para Barros, o sublime está no chão, uma descida vegetal ou coisal. 
O tema da coisa em Barros é associada à noção de Caieiro de que Deus se revela na materialidade da natureza. No entanto, para a crítica, há uma diferença: Mas entre $\mathrm{O}$ guardador de rebanhos e $\mathrm{O}$ guardador de águas abre-se não só o hiato de quase um século e de uma nacionalidade, mas sobretudo o de uma vertiginosa descida. Ele [Alberto Caeiro] pousou na superfície da paisagem bucólica e não chegou a descer, como Manoel, às coisas ínfimas do chão. (Castello Branco, 1998, p. 66).

Aurora Fornoni Bernardini, em "Aspectos da natureza em Velimir Khlébnikov e Manoel de Barros", faz uma comparação entre os dois autores mencionados no título do seu ensaio.

Colocando em contraste trechos de textos dos escritores, Aurora arranja-os por blocos temáticos: a palavra desautomatizada e a relação/oposição entre literatura e ciência. Na seqüência, é feito um levantamento dos vocábulos mais obsessivos de Barros e Khlébnikov, além da análise da presença da natureza nos textos do escritor brasileiro e do autor russo.

Associando as idéias de Barros com as de outro russo, o teórico Vitor Chklovski, Maria da Graça Cretton, em "O regional e o literário em Manoel de Barros", afirma que o escritor brasileiro serve-se de elementos regionais em sua obra, mas também da linguagem geradora de estranhamento: ele utiliza constantemente o procedimento de singularização, apontado pelo formalista russo Vitor Chklovski como característico do discurso artístico [Cretton, 1997, p. 162]. Cretton mostra como Barros executa esse procedimento de singularização:

Empenhado na tarefa de transfazer a natureza, ele [...] entende a poesia, enquanto ocupação de palavra pela imagem, seja esta uma comparação inusitada ("A moça atravessou a rua como se um peixe saísse do armário"), uma antítese ("Escrever é cheio de casca e de pérolas"), uma aliteração ("ovo de orvalho"), ou uma sinestesia ("ardor de pétalas"). Na luta contra os clichês, modifica até mesmo expressões já consagradas pelo uso ("pessoas sem eira nem vaca" ou "Tudo sem pé nem cunhado"). [Cretton, 1997, p. 163]. 
Muitos são os temas estudados na obra manoelina; Thalita Melotto e Marcelo Marinho, por exemplo, interessam-se pelo erotismo, em "Arte, erotismo e representação do universo: da pintura rupestre a Manoel de Barros". Alamir Aquino, no ensaio "O desachamento da finitude em Manoel de Barros", trata da morte, nos escritos de Barros em geral e especificamente em $O$ livro das ignorãças. A polifonia é estudada, em "Aspectos semânticos e lexicais da obra poética de Manoel de Barros", por Emanuela Maria Gemignani Ramires e Ivan Russef que analisam os elementos polifônicos e polissêmicos do poema "O fotógrafo", de Ensaios fotográficos.

A maior recorrência temática na recepção crítica de Barros é o neologismo.

Silvana Augusta Barbosa Carrino Silva, em "A poética manoelina: travessuras lexicais", serve-se da gramática gerativa para analisar o processo de Barros de prefixação e sufixação das palavras. A autora observa, por exemplo, que o estranhamento evidencia-se nas sufixações em “- mente", que em geral transforma a palavra base em advérbio. Manoel acrescenta esse sufixo em situações inesperadas: mulhermente, vegetalmente, antesmente.

Simone Cristina Spironelli e Aparecida Negri Isquerdo, em "O vocabulário de Manoel de Barros: um estudo sobre os neologismos", analisam a criação de novos vocábulos na obra do poeta. Observam que há neologismos fonológicos, sintagmáticos e semânticos e concluem: a palavra parece ir além do leque de possibilidades que seu significado sincrônico usual oferece, ou seja, o estranhamento causado pelo poema motiva o leitor, a atribuir sentidos aos versos que vão além dos traços semânticos mais costumeiros contemporaneamente.

Waleska Martins e Marcelo Marinho, em “A obra poética de Manoel de Barros: o processo de criação de neologismos", observam as várias dinâmicas da invenção de palavras na obra manoelina. Dou destaque à explicação do neologismo "desler":

Em "Estou deslendo" (Livro sobre nada), o prefixo 
"des-" reverte o processo de leitura e indica um retorno a um estado de conhecimento anterior ao aprendizado pelas letras. [Martins \& Marinho, 2002, 51-52].

O tema da infância foi estudado por Afonso de Castro, em A poética de Manoel de Barros: a linguagem e a volta à infância, Dissertação defendida na UnB, que virou livro. Ao analisar o texto "Introdução a um caderno de apontamentos" de Concerto a céu aberto para solos de ave, Afonso afirma que nesse escrito o ponto de vista é o de uma criança: um netinho, que vê seu avô sendo elevado aos ares por uma árvore que começou a brotar no porão de sua casa. Baseando-se nas reflexões de Bachelard, que afirma que a infância é morada da criatividade, ludicidade e da descoberta do mundo, Afonso acredita que a proximidade da figura do poeta com a da criança é bastante adequada já que o poeta se serve de uma linguagem que se reinventa com a realidade em devir. Ela é o ritmo da ludicidade em devir. [Castro, 1992, p. 183].

José Luís Marques López Landeira, em sua Dissertação “A construção do sentido na poesia de Manoel de Barros", defendida na Universidade de São Paulo, em 2000, afirma que o autor cuiabano tem atitudes de filólogo, já que não só aprecia os neologismos mas também mostra conhecimento de variantes antigas das palavras: o poeta areja o acervo lexical [...], mas por revitalizar antigos [elementos lingüísticos], ao passo que remete o leitor para o passado da língua. [Landeira, 2000].

Esse trabalho empenhado de Barros com a palavra leva o estudioso a valorizar a leitura manoelina de Antônio Vieira. Landeira cita um trecho de uma entrevista de Barros no qual o autor mostra seu apreço pelo autor de "O Sermão dos peixes":

Quando eu tinha 13 anos, [Padre Ezequiel] me deu para ler um livro do padre Vieira. Fiquei alucinado. Vieira despertou em mim o gosto pela frase, pela sintaxe, pela construção sofisticada. ${ }^{17}$

17 Barros em entrevista a José Castelo (18/10/1997), O Estado de São Paulo, apud: Landeira, 2000. 
Landeira nota também o Manoel leitor dos dicionários, valorizando a observação de Cynara de Meneses: ela viu na estante do autor um dicionário 'desbeiçado' e com a lombada torta [apud: Landeira, 2000] por causa do seu uso freqüente.

Alguns críticos escreveram na orelha dos livros de Barros questões dignas de serem mencionadas, como Anna Regina Accioly, em Gramática expositiva do chão. A crítica destaca a importância da releitura dos escritos manoelinos: Manoel de Barros descobriu o milagre da multiplicação das leituras: sua poesia não se esgota, e maravilha sempre quem a lê, com encanto impossível de se acabar [Accioly, orelha de GEC].

Talvez o movimento da releitura seja requerido pela complexidade do texto manoelino em si, pleno de neologismos e de palavras arcaicas. O talento manoelino de criar novas palavras e retomar as que não são muito usadas contemporaneamente foi ressaltado por Antonio Houiass, no textoorelha da primeira edição de $O$ guardador de águas, publicado pela Art Editora, em 1989. O crítico e filólogo afirma: Manoel de Barros é um usuário ou utente ou utilizante ou criante de palavras - havidas, havíveis que sangram, sorriem, safadeiam, sacaneiam, lirizam, luziluminam que convidam o leitor a gozar - na bruteza da vida que corre - a infinita graça da disponibilidade mental para o gratuito. [Houaiss, orelha de GA].

Um outro motivo para a necessidade das releituras do texto manoelino pode ser encontrado no comentário de Lucia Castello Branco na orelha de Livro sobre nada: as armadilhas verbais e as diversas referências a outros escritos: Ali nos litorais da escrita, um lápis atravessa a paisagem da memória: corta, recorta, assinala, sublinha, rasura. São epígrafes, citações, referências, notas de pé de página que oferecem falsas pistas ao leitor, traçando o movimento de uma segunda mão que escreve, nos espaços paratextuais, o desnome desse sujeito poético desacontecido. [Branco, orelha de LN].

Lucia afirma ainda que naquele livro a primeira pessoa se evidencia seja quando o poeta cita seus próprios versos de obras anteriores, seja quando o nome próprio do autor se assina em "idioleto manoelês archaico". 
Mas, se o que se escreve é um desnome que aponta, não só para a vacuidade - o nada -, como para a alteridade - "o melhor de mim sou Eles" -, o "eu" afinal não passa de mais um dos retratos que o lápis esquecido na península da memória será capaz de inventar. [Branco, orelha de LN].

Adalberto Müller Júnior, no texto-orelha "Em pleno uso de poesia", do livro Matéria de poesia, afirma que Barros mantém a frase num espaço de tensão permanente entre o obscuro e o iluminante, dando no leitor a sensação de que foi quebrado "quebraram dentro dele um engradado de estrelas". [Müller Júnior, orelha de MP].

O crítico afirma ainda que em sua obra aparecem diversos tipos de "loucos de água e estandarte", andarilhos-poetas que perambulam num mundo às avessas, vivendo numa espécie de terceira margem entre o mundo e o imundo, entre o primitivo e o civilizado. [Müller Júnior, orelha de MP].

Ana Miranda, na orelha de Tratado geral das grandezas do ínfimo, destaca o ver: Você vai voar um vôo de conhecer um mundo que fica não só lá embaixo na terra, no caracol, no pantanal e nem nas nuvens que correm o céu todo do azul, mas um mundo que nunca esteve em lugar algum, porque está só nas rodas de vidro dos olhos do passarinho porque este passarinho sabe tudo o que não vê, e o que não é, por tanto ser. Nos olhos do passarinho tudo está, e o que é visto lá do alto no vôo explica tudo tanto que o mistério abrirá o seu coração por palavras que são chaves que abrem amores e lágrimas, e as palavras que ainda não nasceram e são todo o impossível da vida e são a vida em orvalho, rastros, ventos, sonhos. [Ana Miranda, na orelha de TGGI].

A crítica observa, também, a importância do silêncio da escuta: Você, que vai ler este livro, [...]. Você escutará o silêncio das pedras, das águas dos chapéus, e o silêncio do seu próprio vôo. [Ana Miranda, na orelha de TGGI].

Nesses textos-orelhas mencionados, aparece uma questão importante e pouco trabalhada pelos outros críticos: o efeito do escrito manoelino no leitor. Já com relação aos outros ensaios, evidencia-se o próprio Manoel 
leitor, seja de dicionários, de Vieira, de Caeiro, de Drummond e de outros, o que não poderia ser diferente, pois a erudição manoelina não pode ser ignorada.

A tese "A poética de Manoel de Barros e a relação homem-vegetal" [FFLCH-USP], escrita em 2006 e defendida no ano seguinte, por Nery Nice Biancalana Reiner trata da presença de elementos vegetais nos escritos manoelinos, comparando-os com textos de Cecília Meireles, do escritor moçambicano e de outros. Suas reflexões sobre esse assunto, tomando um poema de $O$ livro das ignorãças, serão mostradas no quarto capítulo desta tese.

Até o momento, parece que o que mais chama a atenção da crítica é a linguagem de Manoel, principalmente a sua dicção peculiar afeita aos neologismos. Percebo, entretanto, que, assim como os neologismos, os silêncios também devem ser alvo de atenção do intérprete de Barros, como notaram Miranda, Ferreira, Fernandes e Marinho. 


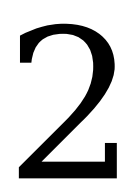

MUTISMOS EM MANOELÊS 
Uso as palavras para compor os meus silêncios. [MII].

\section{OBRAS SILENCIADAS}

Poesia é [...] os silêncios sem poro.

[CUP].

A inarticulabilidade está presente já no primeiro livro de Manoel de Barros, Poemas concebidos sem pecado, de 1937: Entrar na Academia já entrei/ mas ninguém me explica por que que essa torneira/ aberta/ neste silêncio de noite/ parece poesia jorrando... [PCP - 27].

O silêncio noturno evidencia e valoriza, assim, o som da torneira aberta, pois os barulhos do dia não permitiram notá-lo. Aparece, então, o mutismo da escuta, pois quietamente ouvem-se, nesses Poemas ..., não somente torneiras noturnas, mas também as falas do povo.

Escuta-se, por exemplo, o cantar de Claudio, um arameiro, ou seja, aquele que coloca arame farpado para cercar as fazendas: De noite na rede estirada/ Nos galhos da árvore/ Claudio cantava cantarolava:/ Ai, Morena, não me escreve que eu não sei a ler. [PCP - 63].

Silenciar para ouvir boiadeiros é uma tarefa de Barros, que já entrou no seu primeiro livro. Portanto, nove anos antes do primeiro livro de Guimarães Rosa, o Sagarana, Manoel já apresenta o peculiar e rico dizer desses homens: Nisso chega um vaqueiro e diz:/ - Já se vai-se, Quério: Bueno, entonces seja felizardo, lá pelos rios de janeiros... [PCP - 17].

Diferente dos futuros vaqueiros rosianos este, manoelino, mistura palavras do português e do espanhol [bueno, entonces], porque vive na fronteira entre Brasil e Bolívia.

Ocorre, então, o silêncio para ouvir as torneiras noturnas, o canto dos 
arameiros e o dizer dos boiadeiros. O resultado é um livro avesso ao preconceito, que registra e valoriza manifestações populares e/ou pantaneiras, apontando termos e expressões como: frechou; sesso; disilimina; negro é igual com branco; a gente matávamos bentevi a soco; voltou de ateu; disaparta; num (no lugar de não); home-de-bem; passá um taligrama; té a volta; véia; vãobora etc.

O sujeito poético de Poemas concebidos sem pecado indica o seu horror à linguagem formal e artificial, distanciada do povo. Mostra o quão ridícula é a tentativa de um literato corumbaense de mudar o nome de Mário-pega-sapo para Mário-captura-sapo:

Quando Mário morreu, um literato oficial, em necrológico caprichado, chamou-o de MárioCaptura-Sapo!/ Ái que dor!/ Ao literato cujo fazialhe nojo a forma coloquial.| Queria "captura" em vez de "pega" para não macular (sic) a língua lá dele.../ O literato cujo, se não engano, é hoje senador pelo Estado./ Se não é, merecia. [PCP 43-44].

Mário-pega-sapo gostava de ficar na draga, um lugar em que se aglomeravam seres pobres com um rico modo de se expressar: Da velha draga/ abrigo de vagabundos e bêbados, restaram as expressões: estar na draga, viver na draga por estar sem dinheiro, viver na miséria/ Que ofereço ao filólogo Aurélio Buarque de Holanda/ Para que as registre em seus léxicos/ Pois que o povo já as registrou. [PCP - 44].

Em Poemas concebidos sem pecado, aparece também o silêncio da incomunicabilidade: o já mencionado Mário pega sapo, fã de velórios, com seus bolsos estufados de jias, tinha um sério problema: apenas um grupo restrito de pessoas o compreendia: Só as crianças e as putas do jardim entendiam a sua fala de furnas brenhentas. ${ }^{14}$ [PCP - 43].

Já na primeira estrofe da obra, um importante escritor brasileiro, por intermédio de uma de suas célebres personagens, é citado: Sob o canto do batenum-quara/ Nasceu Cabelundinho/ Bem diferente de Iracema/ Desandando

\footnotetext{
${ }^{14}$ Mário-pega-sapo realmente existiu, como afirma meu pai, Julio Galharte, que sempre o via pedir para entrar nos quintais de vários moradores da cidade de Corumbá, para pegar sapos; isso ocorria principalmente em tempos de chuva. Era visto pelas esquinas acariciando os bichos.
} 
pouquíssima poesia. [PCP - 9].

Bem diferente e bem parecido com Iracema é o Cabeludinho manoelino: ambos têm o cabelo comprido. No entanto, o modo como isso é expresso é bastante diverso:

Iracema, a virgem dos lábios de mel, que tinha os cabelos mais negros que a asa da graúna, e mais longos que seu talhe de palmeira. [Alencar, 1991, p. 14].

- Vai desremelar esse olho, menino!

- Vai cortar esse cabelão, menino!

Eram os gritos de Nhanhá. [PCP - 9].

O tom grave e lírico da descrição alencariana é substituído por uma dicção mais corriqueira e marcada pelo humor, no contexto do livro de Barros.

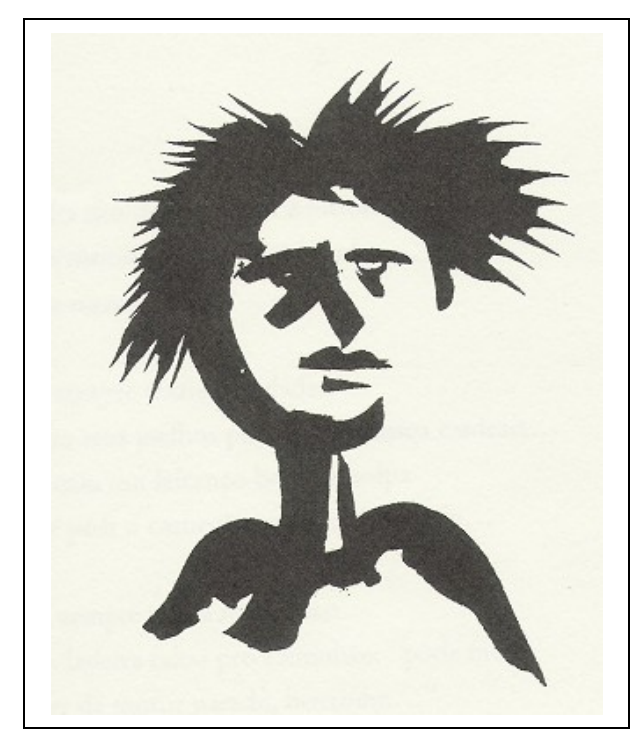

Imagem criada por Jorapimo, que está em PCP.

Na gravura de Jorapimo representando Cabeludinho, pode-se ver um pássaro, com suas asas no lugar do ombro do menino, tendo seu bico voltado para trás. A boca bem parece o Morro do Pão de Açúcar, do Rio de Janeiro, lugar para o qual a criança vai, deixando sua mãe, Nhanhá, chorando feito uma desmanchada. [PCP - 17].

A conjugação entre o ser humano e a natureza, feita por Jorapimo, é 
bastante feliz em se tratando dessa e de outras obras de Barros. Em trecho de Poemas..., o já mencionado arameiro Claudio confunde-se com outro ser: De tão sós e sujos/ Claudio e esse jacaré se irmanavam. [PCP - 63].

A namorada de Cabeludinho, tal qual Iracema, amalgama-se com a fauna: Em seus joelhos pousavam mansos cardeais... [PCP - 13].

O sujeito poético de Poemas... afirma que é bugre mesmo, assim como o autor e talvez, justamente por ter uma descendência indígena e lusitana, Manoel ficou impactado com a leitura de Iracema, que trata justamente do encontro tenso, mas muitas vezes amoroso entre índios e brancos.

Poemas concebidos sem pecado apresenta uma complexidade que não se vê na obra alencariana, gerada em parte pelo silêncio do subtexto. Nesse sentido, o livro de Barros está mais próximo das obras de Mário de Andrade. Não por acaso, Manoel, em entrevista, comenta que há um diálogo implícito de Poemas... com Macunaíma e também aponta outro tipo de mudez: o mutismo da recepção crítica: Achava que o livro ia estourar. Eu andava lendo muito Alencar e Mário de Andrade. Fiquei com aquele ritmo do início de Iracema e de Macunaíma. Na ingenuidade dos meus 19 anos, achei que os críticos descobririam a semelhança entre mim e eles e me elevariam ao nível de Mário de Andrade. Mas foi o maior silêncio, ouço ele até hoje. [Barros, apud: Béssa, 2002, p. 54].

Se há o silêncio da leitura, comentado por Walter Benjamin, existe também o da falta dela, como atesta Barros. Retomando o silêncio do subtexto andradiano no texto manoelino há uma passagem da obra do autor cuiabano que lembra a célebre rapsódia modernista. A mãe de Cabeludinho conversa com o esposo:

Nhanhá mijava na rede porque brincou com fogo de dia

- Mijo de véia não disaparta nosso amor, né benzinho?

- Yes!

[...] O mijo de Nhanhá sentia, no pingar, um vazio inédito $e$ fazia uma lagoinha boa no mosaico...

Desse tempo adquiri a mania de mirar-me no espelho das águas... (PCP - 40). 
A inarticulabilidade mítica de quem se mira mudamente no espelho está aqui nesse Narciso pantaneiro, que juntando erudição e cultura popular, bem como o lírico e o grotesco, tal qual Andrade, vê-se na lagoa de urina da mãe. Em Macunaíma, a mãe do protagonista, a rede e a ação de urinar, registrada popularmente com o termo mijar, estão presentes nesta passagem:

Quando era pra dormir trepava no macuru pequeninho sempre se esquecendo de mijar. Como a rede da mãe estava debaixo do berço, o herói mijava quente na velha, espantando os mosquitos bem. [Andrade, 2004, p. 13].

A erudição de Barros já se revela nesse primeiro livro; além de mencionar José de Alencar, nas linhas, e Mário de Andrade bem como Narciso, nas entrelinhas, o poeta cita ainda, da literatura grega, o autor Péricles e a personagem Clitemnestra, Olavo Bilac e a Bíblia (em menção à Sodoma).

Em Poemas..., há também o silêncio imagético, que aparece na referência ao pintor Raphael em poema homônimo. Mas esse Raphael não é célebre, é um anônimo filho de uma lavadeira, Petrônia, e de um curador de bicheiras de gado, Juvêncio: [...] Raphael não era o pintor/ Nem o anjo de Raphael. Ponhamos que fosse um anjo/ o anjo de sua mãe. [PCP - 67].

Cenário de luar. Segundo ato. Papagaio louro de bico dourado estava com fome/ desceu das folhas verdes[...] E começou a roer um naco / Um naco da testinha tenra/ De Raphael. [PCP - 68]. Há, nesse poema, um quase silêncio trágico, pontuado por seus elementos teatrais: Cenário de luar. Segundo ato. [PCP - 68]. Tais elementos são destacados na gravura de Poty para o escrito. 


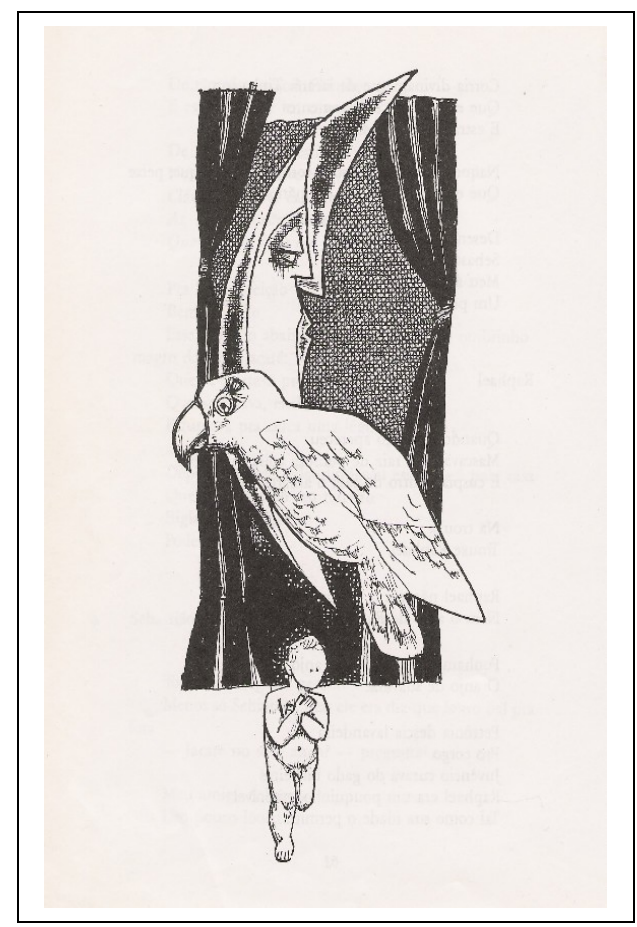

Desenho de Poty para o poema citado de PCP

Esse escrito está numa seção intitulada "Retratos a carvão", na qual aparece também Polina, uma criança negra, já com experiência de sofrimento. Uma outra retratada é Antoninha-me-leva, uma prostituta que às vezes recebia até quatro comitivas de boiadeiros. Bonifácia, certa vez, quis ajudá-la e morreu, sendo enterrada no terreiro com o seu casaco de flores. Quase ao final do poema, lê-se: A fome não é invenção de comunistas, titio. [PCP - 73].

O gosto manoelino por imagens se revela no título de outra seção do livro, "Postais da cidade", na qual se vê um "quadro" de Corumbá: a cidade era em cima de uma pedra branca enorme [...] sobrados remontados na ladeira, flamboyants, armazéns de secos e molhados / E mil turcos babaruches nas portas comendo sementes de abóbora... [PCP- 39].

Aparece também o mutismo de uma escultura, ironizada pelo sujeito poético: Depois, subindo a ladeira, vinha a cidade propriamente dita, com a estátua de Antônio Maria Coelho, herói da Guerra do Paraguai, cheia de besouros na orelha. [PCP-39].

Na seqüência, surge uma referência à sétima arte: $E$ mais o Cinema Excelsior onde levavam um filme de Tom Mix 35 vezes por mês./ E tudo o mais. 
[PCP- 40].

O olhar de Barros já era incansável na busca de livros nacionais e estrangeiros bem como na busca de imagens das mais diversas artes visuais. Não por acaso Pedro Lobo, ao compor a fotografia que estampa a capa das últimas edições de Poemas... escolheu um olho para representar a obra. Olho que, com o mundo em sua íris, alarga-se no mirar buscando letras, números e imagens do universo com suas estrelas.

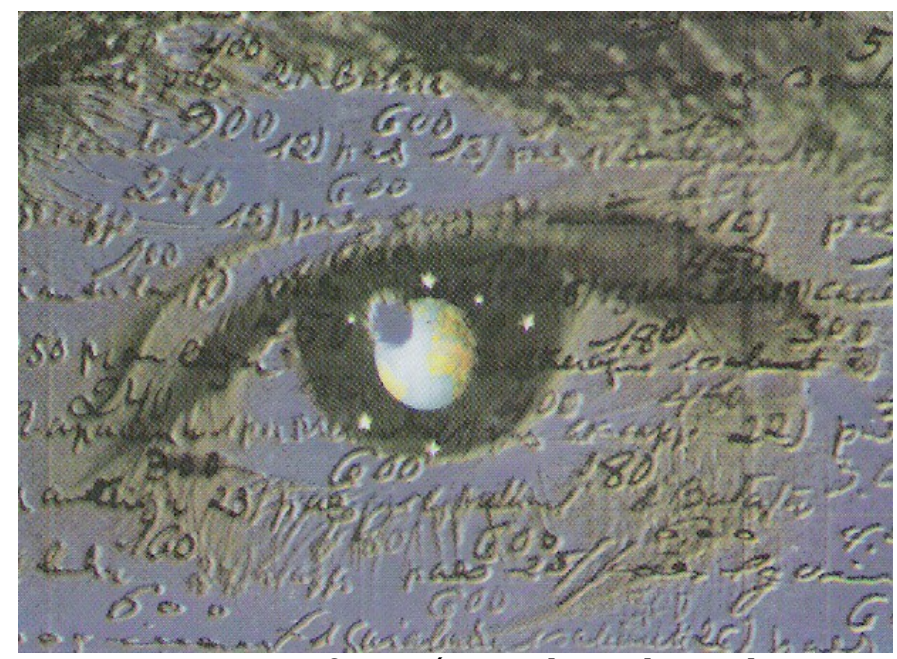

Fotografia artística de Pedro Lobo,

que consta na capa das últimas edições de PCP.

Em 1942, é publicado Face imóvel, que foi enviado por Barros a Mário de Andrade, pois existe um volume dessa obra no acervo da biblioteca do autor de Paulicéia desvairada, presente no Instituto de Estudos Brasileiros, na Universidade de São Paulo.

Há uma dedicatória de Barros para Andrade, em que se apreende o silêncio gestual e a inarticulabilidade da escuta de uma autor preocupado com a oralidade (ler é ouvir):

Mario de Andrade, quantas vezes, nesta minha admiração por você, fiquei vendo seus gestos de longe, ouvindo sua voz... Parecia-me, a mim, que quem escrevia aquelas coisas não era um homem de carne $e$ osso.

of. o autor Manoel de Barros. Rio, 16-10-42.

Escritório Irmãos Barros Ltda. Mato Grosso - 
Corumbá.

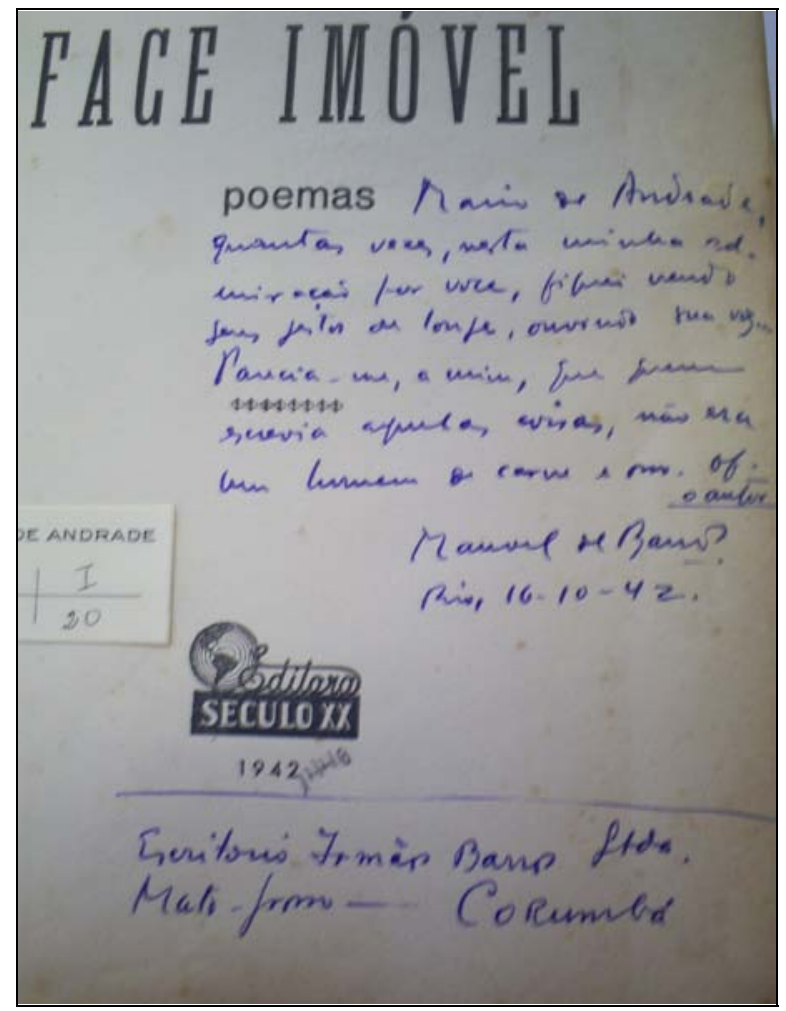

Dedicatória de Manoel a Mário em Face imóvel.

A inarticulabilidade gestual também desponta em um dos poemas do livro: um poeta compreende os significados do movimento dos braços de Pedro:

$$
\text { O GESTO }
$$

[...] E como Pedro estivesse escrevendo umas coisas com a mão, [o poeta] resolve assistir./ Pedro descrevia sua casa, suas filhas malucas, a mulher analfabeta./ Pedro descrevia a inutilidade do presente [...]. [FI $16]$.

O silêncio da solidão aparece no poema "Eu não vou perturbar a paz": De tarde um homem tem esperanças./ Está sozinho, possui um banco./ De tarde um homem sorri./ Se eu me sentasse a seu lado/ Saberia de seus mistérios/ Ouviria até sua respiração leve./ Se eu me sentasse a seu lado/ Descobriria o sinistro/ Ou doce alento de vida/ Que move suas pernas e braços./ Mas, ah! Eu não vou 
perturbar a paz que ele depôs na praça, quieto. [FI - 59].

O silêncio da incomunicabilidade está também presente no livro:

INSTANTE ANUNCIADO

Um chapéu velho!/ Eu não via seu rosto, que um velho chapéu,/ Esmaecido pelo sol, cobria./ Mas sei que não chorava/ E nem tinha desejo de falar./ Porque sabia que alguma coisa vinha chegando/ De manso, alguma coisa vinha chegando.../ Eu não via seu rosto,/ Seu rosto sombreado que um velho chapéu,/ Esmaecido pelo sol, cobria./ Mas sei como ele amou aquele instante/ Mas sei com que prazer ele esperou/ Aquela que viria com os lábios úmidos para ele/ A que havia de vir passar as mãos/ Pelos seus joelhos feridos. [FI68-69].

O silêncio das coisas é mencionado: Não possuía a pintura de outros tempos./ Era um muro ancião e tinha alma de gente./ Muito alto e firme, de uma mudez sombria./ [...]. [FI 65].

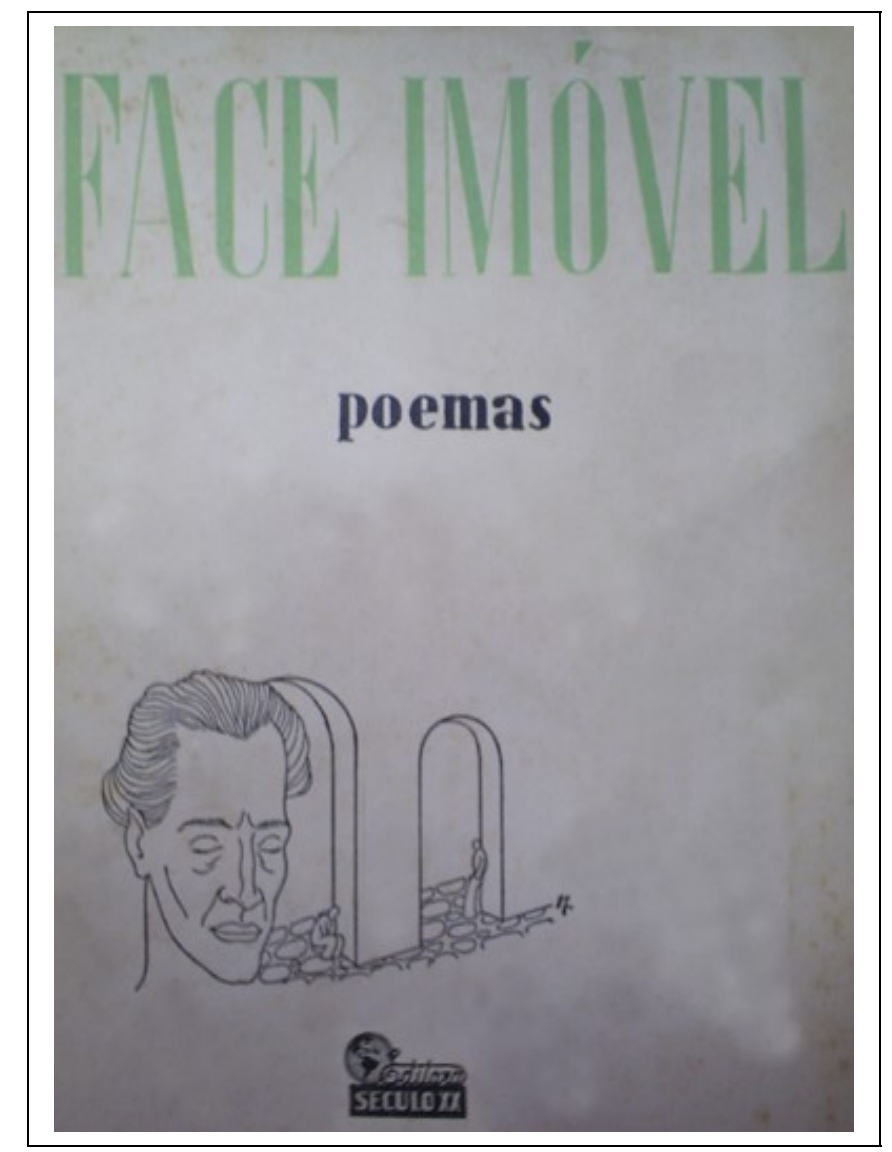

Capa de Face imóvel. 
No poema "Balada do Palácio do Ingá", o sujeito poético se vê numa sala de espera à procura de um emprego. Mira, então, vários retratos na parede, mas seus olhos preferem uma outra imagem:

Benjamin Constant na parede me olha. [...] Os varões na parede me inspiram brasilidade. Será que o Duque de Caxias por cima de suas medalhas; E de sua suspicácia está descobrindo meu olhar guloso para as coxas daquela mulher entreabertas na minha frente? [FI - 70].

O título manoelino dessa obra dialoga com o de um poema de Drummond, no qual a morte é o tema principal: "Os rostos imóveis", do livro José.

Em "Lembrança de uma mulher que morreu", a morte é o centro das atenções. Esse e mais dezesseis outros poemas da primeira edição de Face imóvel ${ }^{15}$ não foram republicados posteriormente no livro Gramática expositiva do chão: poesia quase toda, que reunia todos os livros de Barros até aquele momento, 1990. Há aí o silêncio textual, tanto no corte de alguns poemas quanto no fato de que o livro até o momento não foi mais republicado. A Editora Record, que reedita os escritos de Barros, deixa essa obra de fora do seu catálogo. É bem possível que o motivo disso seja o desejo do próprio autor de não vê-lo republicado, pois já afirmou em entrevista que não aprecia a obra: Face imóvel, editado pela Século XX, do Rio, é meio engajado na política. Eu não gosto deste livro. [Barros, in: Ricciardi, 1991, p. 99].

Realmente, nessa obra, a inarticulabilidade de fonte histórico-política é o destaque, inclusive, o mutismo do pós-guerra é largamente explorado na obra. Em "Poema do menino inglês de 1940", por exemplo, é mencionada uma realidade de bombardeios, perda e silêncio:

A rua onde eu morava foi bombardeada. Nunca nós havíamos de pensar que uma coisa dessas pudesse acontecer. [...]. Ontem de tarde eu vi o pai de Katy,

\footnotetext{
${ }^{15}$ Os outros poemas são "Libertação", "Lembrança", "Os galhos”, "De glaucos olhos imorais", "Para o álbum de Nedy", "Ruas antigas", "Poema", "Elegia matinal", "Sinos perdidos", "Homens diante do mar", "Retrato", "Amargura lírica", "Chuva", "Corpo", "Lembrança de uma mulher que morreu", "Do amor e da vida".
} 
voltando do trabalho - e nunca mais o verei. Porque por onde ele passou as ruínas fumam silenciosamente... [FI - 40].

No poema "Mansidão", o título parece ser enganador, pois um silêncio tenso faz-se sentir no ar: As casas dormiam na hora surda do meio dia./ O corpo do homem penetrou sob árvores/ Na longa quietude estendida na rua./ Tudo permaneceu sem um grito,/ Um pedido de socorro sequer. [FI - 36].

Em "Ruas antigas", a referência bélica é direta: Ó velhas ruas provincianas, quantos homens já vos pisaram pálidos e firmes,/ no começo deste século, ouvindo os rumores de uma guerra interminável... [FI - 26].

Em 1956, é publicada a obra Poesias, que é um livro silenciado, ou seja, ele, como Face imóvel, não foi mais reeditado a não ser em 1990, em Gramática expositiva do chão: poesia quase toda. O motivo é um mistério, pois Manoel aprecia o escrito: é um livro de experiências... me parece que estava procurando a liberdade de expressão. Não desgosto dele. [Barros, in: Ricciardi, 1999, p. 99].

Se em Face imóvel, o sujeito poético apresentava os silêncios ligados à guerra mundial, o de Poesias mostra os mutismos associados à guerra de cunho pessoal, interna: Para quem guardei na minha carne/ As cicatrizes das batalhas perdidas? E os sulcos/ Regados pela chuvas de abril? Para quê?/ Guardei as colinas do meu corpo? Senão/ Para ele caminhar... E minhas mãos de aurora/ Senão para ele acariciar? E meus cabelos negros?/ Ai, não sei. Não posso enganar-te. Pai. Aberta/ Estou, como pétalas noturnas,/ Para os astros. Minha boca silenciosa. [...]. [P, in: PQT - 79].

O silêncio da leitura está presente no poema "Olhos parados". O sujeito poético começa a remexer num baú de recordações, retomando imagens e situações do passado que lhe são muito caras e, fortemente, presentes. A cidade da infância, os amigos da adolescência, os pais, as irmãs e os irmãos, que estão longe, tudo é lembrado nesse instante de introspecção e mutismo. No encontro com a memória, esse "eu" também se recorda das suas leituras:

Pensar nos livros que a gente já leu, nas alegrias dos livros lidos./ Pensar nas horas vagas, nas horas passadas lendo as/ poesias do Anto./ Lembrar dos poetas e imaginar a vida deles muito triste./ Imaginar a 
cara deles como de anjos. Pensar em Rimbaud,/ Na sua fuga, na sua adolescência, nos seus cabelos cor de/ ouro.[P, in: PQT - 87].

Em Iluminations, de Rimbaud, lê-se: Eu sou o mestre do silêncio [Rimbaud, 1994, p. 15]. Muito da maestria rimbaudiana na arte de calar se deve a seu discurso silentemente obscuro.

O Manoel leitor de Mário de Andrade revela-se intensamente em Poesias, há inclusive um poema em sua homenagem, "Na rua Mário de Andrade". Nele, busca-se o canto não-verbal dos pássaros:

[...].Talvez eu veja algum homem lál que me comoval ou mulher que me deslumbre/ ou criança que me entristeça/ para o resto da vida/ Ou pássaro em alguma árvore/ que me aclare o negro dial com seu canto álacre [P, in PQT - 114].

O termo álacre que caracteriza esse canto é anagrama de uma outra palavra usada no mesmo poema: aclare. Além de sugerir musicalidade na repetição de fonemas, Manoel se apoia na visualidade do poema, deslocando as letras de um termo.

Como um pintor, Barros cria formas multicoloridas em seu poema, que tenta se aproximar do silêncio imagético das artes plástica:

Se houver flores nessa rua

Mário de Andrade - a todos nós

ela agradará

Se houver sobrados líricos

com janelas azuis ou verdes - pronto!

Nada mais necessário será para nutrir uns sonhos brancos...

Não por acaso, na seqüência, o pintor Jean-François Millet é citado:

No fundo vê-se o pai lendo

as suas coisas -

a esposa diligencia o almoço

Haverá uma estampa do camponês

de Millet

e os filhos brincando - que ternura [P, in: $\mathrm{PQT}-115]$. 
No poema de Manoel de Barros, a célebre rapsódia modernista é citada:

Na rua Mário de Andrade/ vou andar.../ Vou ir com Macunaíma

[P, in: PQT - 113].

O título desse livro de Barros dialoga com o de uma obra do célebre autor modernista, pois ele já havia publicado, em 1941, o seu Poesias, reunindo textos de Paulicéia desvairada, Clã do jabuti, Remate de males, A costela do grã cão e Livro azul.

Uma outra obra também incluída em Poesias, de Mário, é O losango cáqui, que é citada em Poesias, de Barros, de uma maneira peculiar: a forma geométrica é a mesma, mas sua cor é mudada:

NA ENSEADA DE BOTOFOGO

Como estou só: Afago casas tortas,

Falo com o mar na rua suja...

$\mathrm{Nu}$ e liberto levo o vento

No ombro de losangos amarelos.

Ser menino aos trinta anos, que desgraça

Nessa borda de mar de Botafogo!

Que vontade de chorar pelos mendigos!

Que vontade de voltar para a fazenda!

Por que deixam um menino que é do mato Amar o mar com tanta violência!

Há uma coincidência entre $O$ losango cáqui, de Mário de Andrade, e Poesias, no qual se encontra o losango amarelo, do poema "Na enseada de Botafogo": ambas as obras problematizam a questão do gênero. Logo na "Advertência" do livro de Mário, lê-se: Me resolvo a publicar este livro assim como foi composto em 1922. É um diário de três meses a que ajuntei uns poucos trechos de outras épocas que o completam esclarecem. Sensações, idéias, alucinações, brincadeiras, liricamente anotadas. Raro tive a intenção de poema quando escrevi os versos sem título deste livro. [Andrade, 1987, p. 121].

Diário? Sensações, idéias, alucinações, brincadeiras, liricamente anotadas? Versos que não pretendem formar um poema? O losango cáqui parece ser tudo isso e o caráter aberto do escrito com relação ao gênero também está presente 
no livro de Barros, pois, apesar de o título apontar para Poesias, há uma "Crônica do Largo do Chafariz" e um conto, ou melhor, um continho:

CONTINHO À MANEIRA DE KATHERINE MANSFIELD

Perdera mais aquele seu dia encantador que, bem usado, poderia, quem sabe? Transformar-se em alguma coisa útil ou de cristal.

Perdera-o entre sonhos e perguntas.

E agora a noite era dos sapos.

E sua boca cheia quase foi entrando para o reino vegetal, escorrendo seiva

E entoando sumarentos beijos. Ela desconfiava.

Os ramos sempre tratavam de adormecer os seus pássaros, friorentos, agasalhando-os.

Dava vontade de saltar pelos muros do quintal onde estava

Ganhar a rua e errar pelos cantos, entre pessoas...

Os braços crescendo, espalhando-se, lavavam-na toda de enormes silêncios.

Seus pés na areia fofa dormiriam... Como raízes?

Sombras acordavam nas trepadeiras.

$\mathrm{Se}$ os pensamentos tivessem voz despertariam com certeza os galos nas cercas

$E$ as borboletas no pé de tamarindo, e todos os patinhos que estavam dormindo debaixo das árvores.

Lúcia passeia amorosamente seus dedos pelos troncos revelhos, - $e$ sobe.

Agora seu quarto parece impregnar-se de um cheiro bom de mato...

A pereira, tão importante em "Felicidade", de Mansfield, está presente em um outro conto do livro, intitulado "O encontro de Pedro com o nojo: Pedro se levanta e vai à janela. Lá fora, bem rente ao muro encardido, uma pereira florida...

Há um poema, intitulado "Infância", no qual o parentesco com a pintura é evidente seja na natureza morta (já que há um peixe morrendo) e também pelo seu colorido: Coração preto gravado no muro amarelo/ [...]. Maçã verde no prato. [P, in: - 110].

Réstias de luz no capote preto do pai. A indumentária da ficção gogoliana aparece aqui num contexto pictórico que faz lembrar o jogo do claro-escuro (a 
luminosidade em oposição ao negrume da roupa). O mesmo verso faz ainda reverberar a já mencionada frase dostoievskiana [Todos nós viemos do Capote de Gogol], prestando homenagem a esse grande pai literário que reverencia os pequenos. Assim, esse capote é do pai.

\section{COMPÊNDIOS E GRAMÁTICAS DO NÃO FALAR}

Compêndio para uso dos pássaros foi publicado em 1961 e um volume dele foi oferecido por Barros a Guimarães Rosa e está disponível no Instituto de Estudos Brasileiros da Universidade de São Paulo. Na dedicatória, lê-se:

Ao meu amigo João Guimarães Rosa, êsses meus inhos engenheiros, engenheirinhos. Com os agradecimentos pela pg. 10 e um abraço do seu constante admirador

Manoel de Barros

Rio, 27, 6, 61

A página dez mencionada por Barros apresenta, em forma de epígrafe, um trecho da novela rosiana "Cara-de-bronze": - Que era quê?/ - Essas coisas.../ ../ $O$ vaqueiro Abel: não-entender, não entender, até se virar menino./ O vaqueiro José Uéua: jogar nos ares um montão de palavras, moedal./ $O$ vaqueiro Noró: conversação nos escuros se rodeando o que não se sabe./ $O$ vaqueiro Tadeu: queria era que se achasse para ele o quem das coisas!/ $O$ vaqueiro Calixto: essas coisas que o Grivo falou: “- Sabiá na muda: ele escurece o gorjeio... Pássaro no mato em toda parte voa torto.

Compêndio para uso dos pássaros tem em sua primeira seção um texto intitulado "Poeminhas pescados numa fala de João". Nela, aparece uma imagem associada ao silêncio que se torna recorrente nos livros manoelinos posteriores, a da boca comida: Jacaré comeu minha boca do lado de fora. 


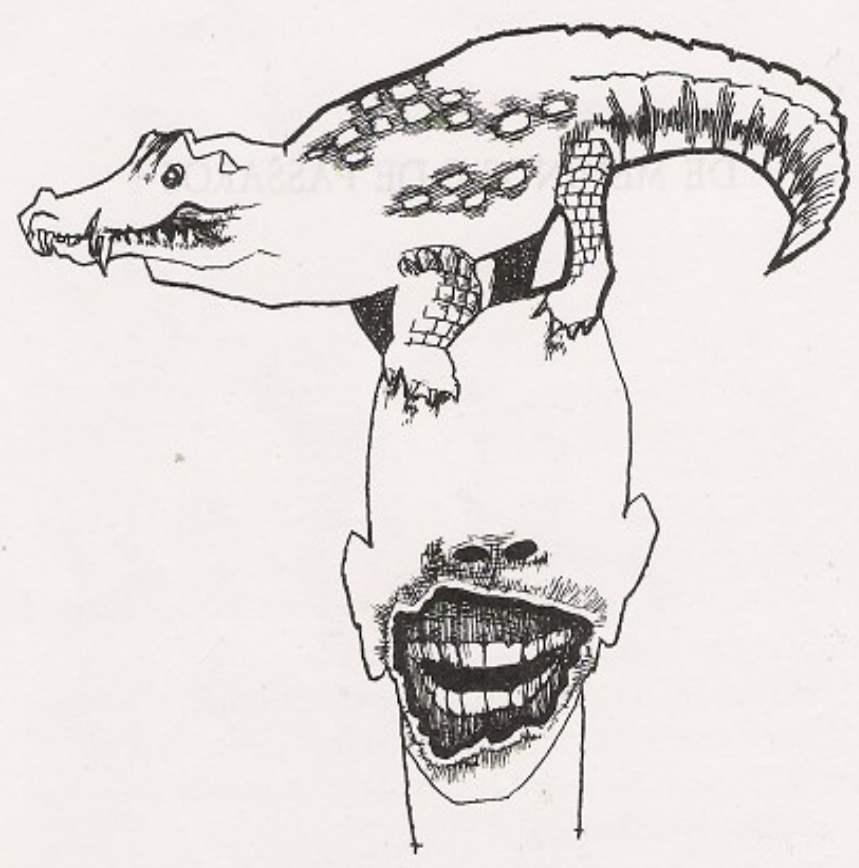

Desenho de Poty para o citado poema de CUP, que consta na coletânea PQT.

A capa tanto da primeira edição quanto das últimas, preparadas pela Record, apresentam o desenho de João Wenceslau Leite de Barros, filho de Manoel, elaborado quando tinha 5 anos.

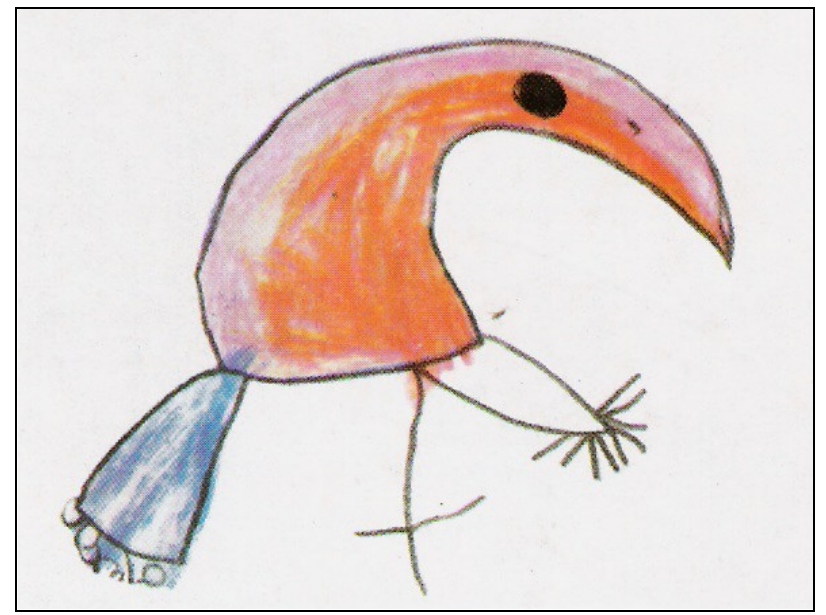

Desenho de João usado na capa de CUP

Talvez seja para o desenhista mirim, o primeiro e já mencionado texto de Compêndio...: "Poeminhas pescados numa fala de João". Esse texto foi 
posteriormente publicado como livro infantil em 2001, e será comentado na última seção deste capítulo.

No poema "O menino e o córrego", dedicado a outro filho de Barros, Pedro, novamente o dizer da criança se confunde com o da natureza: Com a boca escorrendo chão/ o menino despetalava o córrego/ de manhã todo no seu corpo./ A água do lábio relvou entre pedras... [CUP - 25].

A idéia de que a fala primeva das crianças tem características da linguagem não verbal da natureza está também presente em outro poema de Compêndio para uso dos pássaros, "A menina avoada", dedicada à filha do poeta, Martha Barros. Nele, o bico dos pássaros e a boca da menina intercambiam cantos: Eu estava encostada naquela árvore muito azul quase/ e veio um raiozinho de sombra era de tarde na minha boca./ [...] Então dei um salto/ muito leveza/ muito pro vento/ e no bico de uma sabiá eu fiquei de ouro/ a cantar/ a cantar...[CUP - 20-21].

No poema "Um novo Jó", que tem como epígrafe um verso de Jorge de Lima (Porquanto como conhecer as coisas senão sendo-as? [CUP - 51] os musgos devoram a parte do corpo associada à fala: Davam flor os musgos.../ Subiam até o lábio/ depois comiam toda a boca; como se fosse uma tapera. [CUP - 51].

O sujeito poético, ainda nesse poema, indica o mutismo das coisas e afirma que quer ser como elas, ou seja, sem boca, e se servir de comunicações não verbais: Bom era [...]/ Ir a terra me recebendo/ me agasalhando/ me consumindo como um selo um sapato/ como um bule sem boca.../ Ser como as coisas que não têm boca!/ Comunicando-me apenas por infusão/ por aderências... Ser bicho, crianças,/ folhas secas! [CUP - 53].

Sem boca, o sujeito não se ancora na palavra, mas sim na comunicação multissignificativa do silêncio facial: Eu me escorei o rosto nos silêncios.

Em 1966, é editada a Gramática expositiva do chão; o tema da leitura tem destaque na primeira parte do livro, intitulada "Protocolo vegetal". Nela, aparece um preso, provavelmente político, já que é leitor de Marx [a época é a da ditadura militar]. O preso tem ainda um objeto de arte não verbal: 1 lavadeira renga de zinco (escultura inacabada).

No poema "Anti-salmo por um desherói", surge um homem que comia o 
ínfimo com farinha e que se procurava na palavra rebotalho. [GEC - 19-20]. Nesse livro em que os sem importância são fundamentais, não poderia faltar um importante desherói de Fiódor Dostoiévski, especificamente o de Crime $e$ castigo. Assim, com relação ao preso de Gramática... é afirmado que resíduos de Raskolnikov encardiam sua boca de Pierrô muito comida de tristeza. [GEC - 17].

Um grande inspirador dos textos dostoievskianos é mencionado nessa Gramática expositiva...: Nikolai Gógol: O NOSSO HOMEM: ... Como Akáki Akákievitch, que amava só o seu/ capote,/ ele bate continência para pedra! Ele conhece o canto do mar grosso de pássaros, a febre/ que arde na boca da ostra/ e a marca do lagarto na areia./ Esse homem/ é matéria de caramujo.

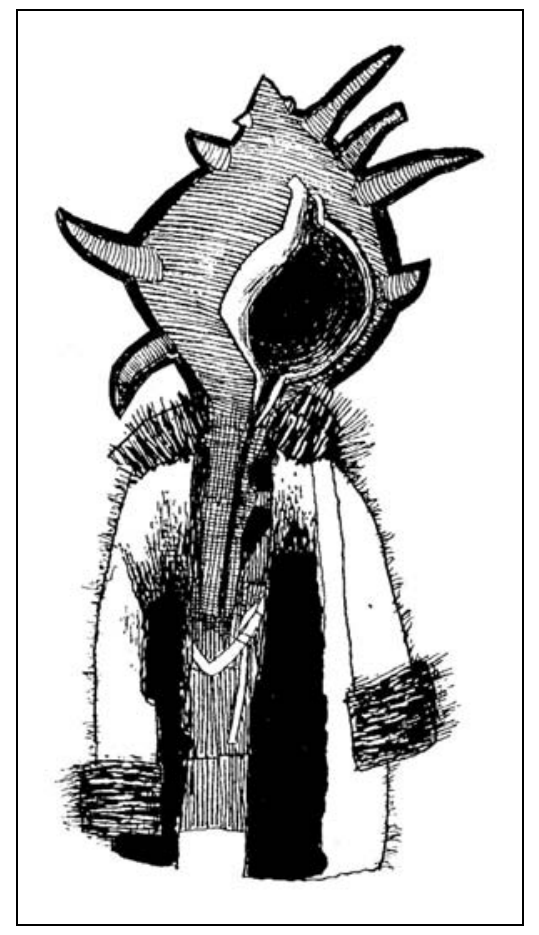

Ilustração de Poty para poema de GEC no qual "O capote” é citado.

Nessa Gramática expositiva do chão, o dizer popular comparece nos "Desarticulados para viola de cocho", derradeira seção do livro. A viola de cocho é instrumento musical usado para o cururu, dança popular do Pantanal. Nesses "Desarticulados..." são registradas as falas de dois "cumpadres" pantaneiros:

- E agora vancê confirme: pardal/ é o esperto? Roupa até usa dos espantalhos?

- É esperto, cumpadre,/ não cai// do galho. [GEC - 53]. 
- E máquina / de dor/ é de a vapor? brincar de amarelinha/ tem amarelos?/ as porteiras do mundo varas têm [...]

- Têm conformes.[GEC - 52].

A máquina de dor mencionada pode ser a do próprio Estado ditador do ano da publicação do livro de 1966. Esta máquina deve ser a mesma, então, de um outro poema do mesmo livro:

\section{A MÁQUINA: \\ A MÁQUINA SEGUNDO H.V., O JORNALISTA}

A máquina mói carnel excogita/ [...]/ vai a chás de caridade/ [...]/ é guiada por pessoas de honorabilidade consagrada, que não defecam na roupa/ [...]/ tritura anêmonas/não é fonte de pássaros/ etc./etc. [GEC 45].

No silêncio das entrelinhas, parece que uma crítica ao regime militar é feita; o discurso com um tom às vezes surrealista ajudou a despistá-la e o texto conseguiu ser publicado, sem esbarrar na censura da época.

A metáfora do dizer obscuro associado ao poeta é mencionada em Gramática expositiva do chão já que sua voz parece vir de um poço escuro [GEC - 39] e, além disso, ele é iniciado em abrolhos. Um abrolho, segundo o Dicionário eletrônico Houaiss é tudo o que dificulta, contraria ou desgosta.

O tema da boca devorada é retomado: Eu vi o chão, era uma boca de gente comida de lodo! [GEC - 40]. A natureza se encarrega de se sobrepor ao verbo, por isso, nessa Gramática expositiva do chão, a boca é coberta pelo limo: $O$ homem de lata é um passarinho de viseira: não gorjeia/ Caído na beira/ do mar/ é um tronco rugoso/ e cria limo na boca. [GEC - 25].

Assim, o verbo falado é suspenso, pois a boca é obstruída pelo lodo ou pelo limo e já que não se pode usar a boca para falar, pode-se usá-la para o mutismo da escuta: $O$ dia todo ele vinha na pedra do rio escutar a terra com a boca $e$ ficava impregnado de árvores. [GEC - 37]. 
Matéria de poesia é livro de 1970 e começa com um arrolamento do que pode tornar-se poema:

$[\ldots]$.

O que é bom para o lixo é bom para poesia

Importante sobremaneira é a palavra repositório;

a palavra repositório eu conheço bem:

tem muitas repercussões

como um algibe entupido de silêncio

sabe a destroços

O silêncio lacunar que se faz nas frestas de uma palavra, está presente, pois o termo repositório tende a gerar repercussões pedindo para o leitor interpretá-lo.

Em Matéria de poesia, lê-se: É nos rotos que os passarinhos acampam! [MP - 26]. Esse verso faz parte do poema “Com os loucos de água e estandarte” e, nele, é mencionado reiteradamente um homem chamado João, que bem pode ser o João de Cruz e Sousa, por causa desses rotos, já que eles estão presentes no poema Litania dos pobres, do Cisne Negro: Os miseráveis, os rotos são as flores dos esgotos/ São espectros implacáveis/ Os rotos, os miseráveis./ São prantos negros de furnas/ Caladas, mudas, soturnas. [Sousa, 2000, p. 148].

Além desse João, ele pode ser também o Cabral de Mello, pois no poema há muitas pedras e rio. Pode ainda ser o João Wenceslau, filho do autor cuiabano. Um outro João seria o Guimarães, já que se lê: Gosto de santo e de boi.

Assim, João se abre para muitas possiblidades de sentido garantidas pelos silenciosos zeros (João) que pedem complementação do leitor. O zero tem graficamente grande proximidade com a letra $O$, talvez por isso Rimbaud associou-a ao mutismo, no poema "Vogais": A negro, E branco, I rubro, U verde, $O$ azul,/ Ainda desvendarei seus mistérios latentes [...]/ O, supremo Clamor cheio de estranhos versos,/ Silêncios assombrados de anjos e universos;/ - Ó! Ômega, o sol violeta dos Seus olhos! [Rimbaud, 1993, p. 37].

Há, também, em Matéria de poesia, a inarticulabilidade dos que não têm voz socialmente:

As coisas jogadas fora

têm grande importância 
-como um homem jogado fora

Aliás é também objeto de poesia saber qual o período médio que um homem jogado fora pode permanecer na terra sem nascerem em sua boca as raízes da escória.

É mostrado o que mais pode se tornar poesia: coisa ordinária, coisa sem préstimo, caco de vidros, garampos (talvez seja uma forma popular ou adulterada de grampos), retratos de formatura, o que não se pode vender no mercado (como o coração verde dos pássaros), sapatos, adjetivos etc.

Em um trecho do livro, lê-se: Muita coisa se pode fazer pela poesia: [...]. Comer as botas, o resto em Carlitos. [...]. [MP - 15].

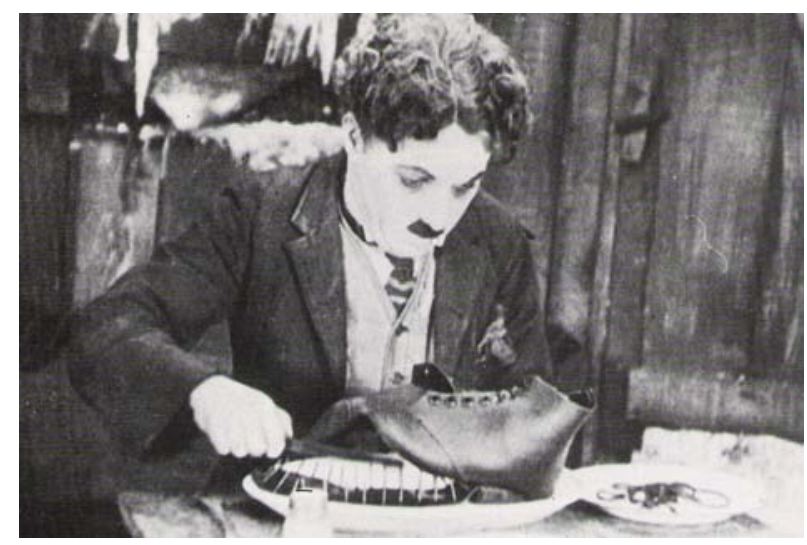

Fotograma de "A busca do ouro", de Charles Chaplin.

A quietude da natureza, também, é mencionada: $N a$ beira do rio silêncio põe ovo; Borboletas chegavam em casa quase mortas de silêncio. A natureza silente continua se sobrepondo ao verbo, pois lagartas devoram escritos: Lembrou-se do quarto: seu quarto cheio de marandovás que comiam livros.

Talvez a inarticulabilidade gerada pela censura, já explorada no livro anterior, esteja presente nestes versos: No balde encontrara um jovem/ com uma tramela na boca! E neste outro: Verbos sumiam no fogo. 
Em Livro de pré-coisas, de 1985, busca-se o silêncio hermético e um dos meios de consegui-lo é por intermédio de entraves gráficos, que resultarão em obstáculos semânticos para o leitor. Essa "receita" de complicação do enunciado, que por sua vez gera o inusitado, o sujeito poético manoelino conseguiu com um célebre autor argentino:

Cortázar conta que quando alguma expressão o queria sujar, ele a camuflava. Assim: expectador ativo, virou Hespectador Hativo. Com essas vestimentas de $\mathrm{HH}$, aquele lugar comum não o sujava mais.[LPC - 64].

Não só a escrita pode se apresentar como uma tapagem, mas também a própria oralidade, já que dela brotam obscuridades: Falando é que não se entende. [LPC - 70].

O mutismo da escuta se repercute no mesmo livro, já que, nele, estão as histórias orais espraiadas no Pantanal de lobisomens e de mulheres que se transformam em cobra quando completam cem anos. O leitor torna-se ouvinte e o enunciador pede que o ouça: $O$ caso eu aprendi de oitiva, xará. Oive de mi. [LPC - 80].

E mais: é no uso de canto e recontos que o pantaneiro encontra o seu ser. [LPC - 33].

$\mathrm{Na}$ enchente pantaneira, as águas evidenciam o silêncio, apagando, com seu corpo, as letras das placas das ruas: $O$ mundo foi renovado, durante a noite, com chuvas. Sai o garoto pelo piquete com olho de descobrir. Choveu tanto que há ruas de água. Sem placas, sem nome, sem esquinas. [LPC - 29].

Ganha destaque, então, a quietez do Pantanal: Por mim, advenho de cuiabanos. Meu pai jogou canga pra cima no primeiro escrutínio e sumiu na zamboada. Há um rumor de útero que muito me repercute nestes brejos. Aqui o silêncio rende. [LPC - 12].

Em O guardador de águas, de 1989, a quietude pantaneira e o silêncio préverbal são tematizados:

Nas Metamorfoses, em duzentas e quarenta fábulas, Ovídio mostra seres humanos transformados em pedras, vegetais, bichos, coisas./ Um novo estágio seria que os entes já transformados falassem um 
dialeto coisal, larval, pedral, etc. Nasceria uma linguagem madrugenta, adâmica, edênica, inaugural / Que os poetas aprenderiam - desde que voltassem às crianças que foram às rãs que foram. [GA - 22].

No Pantanal, são escutados o silêncio de garças [GA - 22], o silêncio a gerânios [GA - 31] e o silêncio líquido [GA - 297]. Também se lê a escrita préverbal de Bernardo, que escreve escorreito, com as unhas, na água, o Dialeto-Rã. [...]. Bernardo conversa em Rã como quem conversa em Aramaico. [GA - 23]. Em nota de rodapé, é explicado: Falado por pessoas de águas, remanescentes do Mar de Xaraiés, o Dialeto-Rã, na sua escrita, se assemelha ao Aramaico - idioma falado pelos povos que antigamente habitavam a região pantanosa entre o Tigre e o Eufrates. [GA - 27].

O mutismo imagético associado ao limite das palavras é tematizado:

Entesouro frases. Por exemplo:

- Imagens são palavras que nos faltaram.

- Poesia é a ocupação da palavra pela imagem.

- Poesia é a ocupação da Imagem pelo Ser. Ai frases de pensar! [GA - 44].

As frases de pensar, plenas da inarticulabilidade do subtexto, estão espalhadas em outros trechos do livro: No que o homem se torne coisal -, corrompem-se nele os veios comuns do entendimento./ Um subtexto se aloja./ Instala-se uma agramaticalidade quase insana, que empoema o sentido das palavras.[GA - 46].

É preciso, então, escavar na linguagem para chegar aos significados entesourados e profundos: Palavras têm espessuras várias: vou-lhes ao nu, ao fóssil, ao ouro que trazem na boca do chão. [GA -56].

É oferecida uma receita para obscurecer o dizer, evidenciando seu silêncio: Escurecer as relações entre os termos em vez de aclará-los. [GA, in: PQT - 299]. Assim, o escritor deve estar aberto apenas à obscuridade e à desexplicação.

A expressão não verbal das artes visuais está no silêncio nos retratos [GA - 
277] com a a cor do êxtase [GA - 285]. Está também nos mutismos dos quadros e das esculturas de Amedeo Modigliani, associados às criações imagéticas dos vôos das garças do Pantanal: De cantos portanto não é que se faz a beleza desses pássaros. Mas de cores e movimentos. Lembram Modigliani. Produzem no céu iluminuras. E propõem esculturas no ar. A elegância e o Branco devem muito às garças. Chegam de onde a beleza nasceu? [GA - 271].

Em 1990, todas as obras de Manoel de Barros até então publicadas foram compiladas num único volume intitulado Gramática expositiva do chão: poesia quase toda, contando com a capa e as ilustrações de Poty.

Há uma introdução de Berta Waldman, na qual são apresentadas as recorrências imagéticas e temáticas do escritor, além de apresentar o diálogo da sua escrita com a de outros autores. O pantanal, segundo a crítica, é importante fonte de inspiração para Barros já que é reino prenhe de riqueza visual, táctil, olfativa [Waldman, 1990, p. 15], no qual se opera a passagem cíclica da morte à vida, apontando para a constante mutação das coisas. [Waldman, 1990, p. 27].

Ao final do livro, são reunidas várias entrevistas por escrito de Barros; em uma delas, publicada anteriormente no Correio Brasiliense, o autor comenta sobre o seu silêncio em público:

Eu gosto de ser recolhido pelas palavras. E a palavra falada não me recolhe. Antes até me deixa ao relento. $O$ jeito que eu tenho de me ser não é falando; mas escrevendo. Palavra falada não é capaz de perfeito.

Quando não se comunica pela escrita, ele o faz pela leitura: Pelo meu temperamento de tímido, que é uma sem-graceira demais, nunca funcionou o diálogo pessoal entre mim e os outros poetas. Senão que só pelo diálogo livresco. [...]. Em livro sou íntimo deles, e os converso e os aprovo ou desaprovo, e rio com eles. [PQT - 326]. A lista de autores citados por Barros, ao longo dessas entrevistas compiladas, é enorme: Thomas Mann, Gilberto Freyre, Goethe, Machado de Assis, Walter Benjamim, Cesário Verde, Federico Garcia Lorca, Leo Spitzer, Casimiro de Abreu, Camilo Castelo Branco, Virgílio, Camões, Gaston Bachelard, Homero, Mário de Sá Carneiro, Barthes, Aristóteles e outros. 
Concerto a céu aberto para solos de ave, de 1991, reverencia, em um de seus trechos, o silêncio hermético, que está presente no círculo de "iniciados" que se servem de uma linguagem compreensível apenas para eles mesmos: Em 1912 ,/ Entrei para uma seita desativada cujos membros/ um pouco dementados/ Se ocupavam de ouvir a ressonância deles mesmos nas palavras (igual que os louquinhos quando ouvem paredes)/ Comecei a saber menos sobre meus desencontros. Uma porção de lodo forçou para baixo a minha voz./ Aprendi que no escuro eu enxergo melhor./ Orvalho benzeu meu olho. [CCASA - 35].

Como São Francisco, o sujeito poético desse livro quer se transformar em "árvore" para as aves (Fui convidado pelas aves para ser árvore) e se atém ao mutismo da visão, ou seja, quer ver a inarticulabilidade da natureza, especificamente a das avencas iluminadas:

Toda vez que a manhã está sendo começada nos meus olhos, é assim...

Essa luz empoçada em avencas.

As avencas são cegas.

Nenhuma flor protege o silêncio quanto elas.

Ó a luz da manhã empoçada em avencas! [CCASA - 15$16]$.

O sujeito poético de Concerto... afirma que está escrevendo uma autobiografia para enfeitar a noite do meu bem [CCASA - 35]. Essa é uma citação de "A noite de meu bem", de Dolores Duran. Assim, o poema quer tornarse canto. O poeta entende que a expressão seria melhor traduzida no cantar dos pássaros, avesso ao verbo: a voz de um passarinho me recita.

"Estudos" são apresentados em Concerto a céu aberto para solos de ave sobre os cantos dos pássaros e sobre os sons emitidos pelos insetos:

Sabiás de outubro não delimpam seus cantos; os de março delimpam. Estamos estudando a razão disso por lâminas de cantos. [CCASA - 60].

Na beira do entardecer o canto das cigarras enferruja. [CCASA - 53].

Mosca zine de magra; zine por nós. [CCASA - 53]. 
Uma das imagens mais importantes do livro é a de um gramofone, que aparece na capa das últimas edições e na história contada nas primeiras páginas da obra: uma árvore cresce pelo meio de uma casa, levando em seus galhos um gramofone e o avô do sujeito poético. Os dois ficam nas alturas e uma anhuma põe um ovo na boca no gramofone. O avô perde as roupas com o vento e depois falece.

Se a música é importante nessa narrativa, o silêncio também o é já que o gramofone com o ovo de anhuma em seu tubo só pode emitir canções silentes. O silêncio da escuta tem grande importância nesse trecho do livro já que o sujeito poético silencia para ouvir e identificar a mudança no jeito de cantar da anhuma, percebendo quando ela anuncia chuva. Sempre que isso ocorria o menino corria para cobrir seu avô, que deixa para ele um caderno de apontamentos.

São usados vários pontinhos em vários segmentos, para a indicação de experiências indizíveis:

Sei de conchas em mim ouvindo hinos.

Estou em vão.

[CCASA - 39].

Akaki Akakievitch, de $O$ capote, de Gógol, é associado a Aristeu deste texto manoelino:

Eu quando conheci o Aristeu-/ ele andava em final de árvore. E andava por aldeias em santidade de zínias./ O ermo fazia curvas para ele./ Subiam-lhe caracóis, ao manto./ O que Gogol falou sobre Akaki Akakievitch, eu diria de Aristeu:/ "Um homem que desceu à sepultura sem ter/ realizado um só ato excepcional"./[...]./ Exerci alguns anos ao lado de Aristeu a profissão de urubuzeiro (o trabalho era,/ espantar os urubus dos tendais de uma/ charqueada),/com esses exercícios os nossos desconhecimentos aumentaram bem./ As coisas sem nome apareciam melhor./ Vimos até que os cantos podem ser ouvidos em/ forma de asas". [CCASA - 45-46]. 
Assim, o urubuzeiro Aristeu pertence à mesma família de seres desimportantes de Akáki Akakievitch. O sujeito poético de Concerto a céu aberto para solos de ave imita a função de Akaki Akakievitch: é um copiador:

Doze dias antes de sua morte meu avô me/ entregou um CADERNO DE APONTAMENTOS. [...]. Por tudo que leio nesses apontamentos, pela ruptura de certas frases, fico em dúvida se esses escritos são meros delírios ônticos ou meral sedição de palavras./ Metade das frases não pude copiar por ilegíveis.

No caso do copiador manoelino, sua função não está associada a um universo limitante ligado à burocracia, mas sim a um mundo de subversões às normas (a ruptura de certas frases) e a uma realidade de um linguajar obscuro (Metade das frases não pude copiar por ilegíveis).

Gógol e Barros se incumbem da mesma empreitada: os silenciados na sociedade ganham voz em seus escritos, os que não têm nome de destaque para o mundo são destacados pelo seu anonimato no universo das suas obras:

As coisas sem nome apareciam melhor./ Vimos até que os cantos podem ser ouvidos em/ forma de asas". [CCASA - 45-46].

Em 1996, José Mindlin edita $O$ encantador de palavras, uma seleção de poemas de Barros, que já haviam sido publicados, com ilustração de Siron Franco. 
O ENCANTADOR

DE PALAVRAS

Desenho que está no início do livro de Barros e que foi retirado de Spix e Martius, Voyage au Brésil. Monachhii, (1825)

Havia também poemas novos à época, que geraram um tremendo entusiasmo no editor, como se nota em sua missiva ao poeta:

São Paulo, 17 de abril de 96.

\section{Querido Manoel:}

Você deve estar estranhando meu silêncio, mas é que eu não queria escrever antes de poder mostrar que o projeto está caminhando, como você pode ver pelo material que recebi ontem à noite de Diana, e que aí vai, para sua alta consideração. Dizer que gostamos das novas poesias, e gostamos muito, creio que é supérfluo. Eu tive quando recebi sua carta e o texto, o impulso de pegar o telefone e manifestar na mesma hora o meu entusiasmo. Mas a lembrança de sua aversão por telefones me conteve... Aí achei melhor dar cópia de tudo à Diana (inclusive sua carta, que ela, que tem boa vista, conseguiu decifrar), para você nos dizer o que pensa. Se preferir soluções diferentes, não faça cerimônia - queremos ver o altíssimo poeta bem contente... [...]. Lembranças à Stella, e um abraço amigo para você, do

Mindlin

[Mindlin, apud: Kikuchi, 2004, p. 156]. 


\section{INARTICULADOS TRATADOS, NADAS...}

Em Livro sobre nada, também de 1996, a voragem do olhar ${ }^{16}$ tem grande destaque; há um trecho em que o sujeito poético mostra que há três ações muito

${ }_{1}^{1}{ }^{6}$ A expressão em itálico é de Regina Pontieri, que é título de seu livro publicado pela Editora Perspectiva. 
caras a ele: ver, rever e transver: $O$ olho vê, a lembrança revê, e a imaginação transvê./ É preciso desformar o mundo: Tirar da natureza as naturalidades./ Fazer cavalo verde, por exemplo./ Fazer noiva camponesa voar - como em Chagall./ Agora é só puxar o alarme do silêncio que eu saio por aí a desformar. [LN - 75].

Assim, é preciso puxar o alarme do silêncio para desformar, feito Chagall. A capa de Livro sobre nada traz aos olhos do leitor o silêncio da desforma de Wega Nery e os seus "Pássaros na madrugada". A artista criou outras quatro ilustrações que separaram as seções da obra.

O olho do sujeito poético de Livro sobre nada atém-se a leituras muitas, citando Antônio Vieira, Charles Baudelaire, William Shakespeare, Gustave Flaubert e os existencialistas.

A declaração de José de Alencar de que não só obras francesas o inspiraram a escrever, mas também o grande livro sem palavras que é a natureza brasileira aproxima-se deste verso de Livro sobre nada: Tem hora leio avencas. Tem hora, Proust.

Nessa obra existe não só a leitura, mas também a desleitura: $A$ voz do meu avô arfa. Estava com um livro debaixo/ dos olhos. Vô! O livro está de cabeça para baixo. Estou/deslendo. [LN - 29-30].

Transver e desler são ações silenciosas muito caras aos seres de Livro sobre nada. O sujeito poético retorna à infância, e a inarticulabilidade está presente em quase todas as suas recordações: lembra do seu avô que, além de se divertir com as desleituras, tentava vender urinóis usados e era difícil de ser definido por palavras já que era o próprio indizível pessoal. [LN - 27]. Do diário da sua irmã, Bugrinha, copia esse registro: Hoje completei 10 anos. Fabriquei um brinquedo com palavras. Minha mãe gostou. É assim: "De noite o silêncio estica os lírios".[LN - 33]. Do seu Mano Preto, o sujeito se recorda desta frase: Grilo é um ser imprestável para o silêncio.

A procura do silêncio da infância do sujeito poético associa-se à busca da infância da humanidade, por isso ocorre um retorno a um horizonte primordial. O sujeito poético afirma: Escrevo o idioleto manoelês archaico. [LN - 43]. Assim, necessário se faz o arcaico para se encetar uma viagem ao princípio do verbo: 
Carrego meus primórdios num andor./ Minha voz tem um vício de fontes. Eu queria avançar para o começo./ Chegar ao criançamento das palavras./ Lá onde elas ainda urinam na perna. / Antes mesmo que sejam modeladas pelas mãos. Quando a criança garatuja o verbo para falar o que não tem./ Pegar no estame do som. / Ser a voz de um lagarto escurecido./ Abrir um descortínio para o arcano. [LN - 47].

Em Livro sobre nada busca-se o silêncio dentro das palavras. Preciso de atrapalhar as significâncias [LN - 43], afirma o sujeito poético, alertando o leitor sobre seu gosto de dificultar os sentidos em seu discurso. Em uma outra passagem da mesma obra, insiste-se nesse tipo de advertência: Não tenho habilidade para clarezas. [LN - 51].

Em 1999, é lançado o primeiro livro infantil de Barros, Exercícios de ser criança, no qual aparecem duas histórias: "O menino que carregava água na peneira" $e$ "A menina avoada". A primeira mostra um menino que gostava mais do vazio do que do cheio [ESC - sem paginação]. O vazio sendo parente do silêncio requer preenchimentos, aqueles feitos pelos bordados que compõem as ilustrações do livro executados pela família Dumont: a mãe Antônia e suas filhas Angela, Marilu, Martha e Sávia sobre desenhos do irmão Demóstenes.

Também incentivado pela mãe, o menino da história se torna um poeta e tem uma descoberta: No escrever o menino viu que era capaz de ser noviça, monge ou mendigo ao mesmo tempo. [ESC - sem paginação]. 


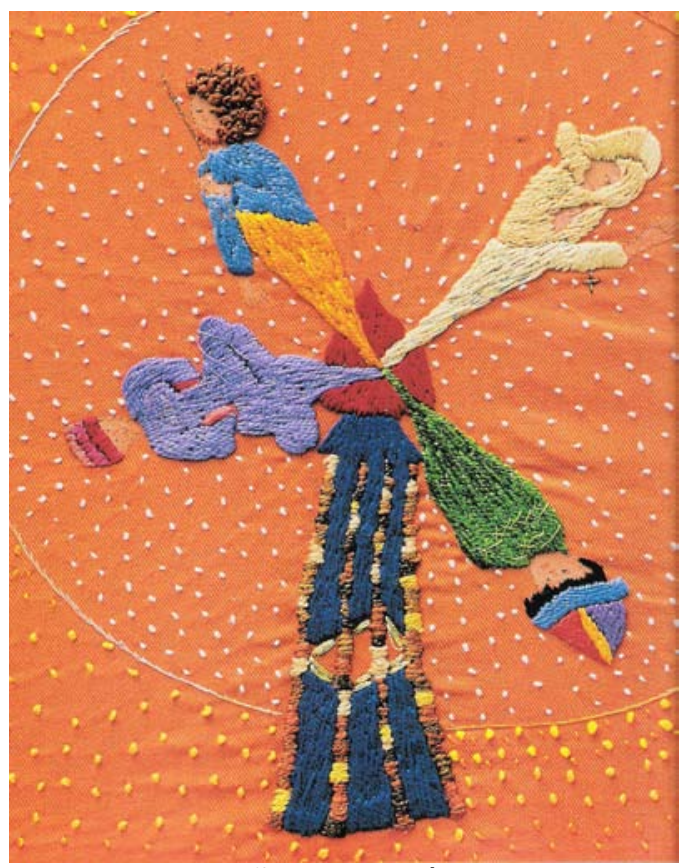

Ilustração da família Dumont para o livro Exercícios de ser criança

Na segunda história, "A menina avoada", uma garota conta que seu irmão costumava levá-la num caixote com rodas de lata de goiabada, que imaginavam ser puxado por dois bois. Os meninos cruzavam um rio inventado, chegando ao fim do próprio quintal.

Apela-se para a pintura (em Livro sobre nada) ou para o bordado (em Exercícios de ser criança), puxando o alarme do silêncio, porque a palavra já não tem mais seu vigor, ela sofreu um processo de deterioração, de esvaziamento, até mesmo a palavra amor, como se vê em Ensaios fotográficos, de 2000:

[...] Minha idéia era de fazer alguma coisa ao jeito de tapera. Alguma coisa que servisse para abrigar o abandono, como as taperas abrigam. [...] O abandono pode ser também de uma expressão que tenha entrado para o arcaico ou mesmo de uma palavra. Uma palavra que esteja sem ninguém dentro. [...] digamos a palavra AMOR. A palavra está quase vazia. Não tem gente dentro dela. Queria construir uma ruína para a palavra amor. Talvez ela renascesse das ruínas, como o lírio pode nascer de um monturo. [EF - 31].

A palavra em crise faz com que o poeta queira se transmutar em pintor ou fotógrafo, que silenciosamente apresenta imagens que tentam falar por si sem o 
intermédio do verbo. A capa tem um desenho da filha de Manoel, Martha Barros, que já anuncia um mundo repleto de imagens que será encontrado no interior do livro.

Joan Miró, sua arte não verbal e sua ruptura com as palavras aprendidas nos livros são evocados neste poema:

\begin{abstract}
MIRÓ
Para atingir sua expressão fontana/ Miró precisava de esquecer os traços que aprendera nos livros./ Desejava atingir a pureza de não saber mais nada./ Fazia um ritual para atingir essa pureza: ia ao fundo/ do quintal à busca de uma árvore./ E ali, ao pé da árvore, enterrava de vez tudo aquilo/ que havia aprendido nos livros./ Depois depositava sobre o enterro uma nobre/ mijada florestal./ Sobre o enterro nasciam borboletas, restos de/ insetos, cascas de cigarra etc./ A partir dos restos Miró iniciava a sua engenharia/ de cores./ Muitas vezes chegava a iluminuras a partir de um dejeto de mosca deixado na tela./ Sua expressão fontana se iniciava naquela mancha/ escura./ O escuro o iluminava. [EF 29].
\end{abstract}

Na epígrafe da primeira parte da obra, aparece um trecho de um texto de Jorge Luis Borges reafirmando a força imagética: Imagens não passam de incontinências do visual. [Borges, in: EF - 9]. A obra borgeana é bastante afeita a imagens e há um livro, Atlas, composto por várias fotos comentadas pelo autor.

O poeta transformado em fotógrafo segue materializando, em imagens, várias abstrações: Tinha um perfume de jasmim no beiral de um sobrado./ Fotografei o perfume./ Vi uma lesma pregada na existência mais do que na pedra. / Fotografei a existência dela./ Vi ainda um azul-perdão no olho de um menino./ Fotografei o perdão. [EF -11].

Surgem, inclusive, instantâneos do silêncio: Difícil fotografar o silêncio./ Entretanto tentei./ Eu conto: Madrugada a minha aldeia estava morta./ Não se ouvia um barulho, ninguém passava entre as casas./ Eu estava saindo de uma festa./ Eram quase quatro da manhã./ Ia o Silêncio pela rua carregando um bêbado. Preparei minha máquina./ O silêncio era um carregador?/ Estava carregando o bêbado./ Fotografei esse carregador. [EF -11].

O silêncio místico está apto à foto em Ensaios fotográficos: aparece na 
fotografia de uma árvore. Deus pode ser encontrado mais na experiência do que no discurso: entre ouvir as palavras dos padres do internato ou fazer um estágio de árvore, o irmão do sujeito poético opta pela segunda alternativa. Assim, vale mais a experiência mística silente do que a verbal:

Um passarinho pediu a meu irmão para ser a sua árvore./ Meu irmão aceitou de ser a árvore daquele passarinho./ No estágio de ser essa árvore, meu irmão aprendeu de sol, de céu e de lua mais do que na escola. No estágio de ser árvore meu irmão aprendeu para santo mais do que os padres lhes ensinavam no internato./ aprendeu com a natureza o perfume de Deus. Seu olho no estágio de ser árvore aprendeu melhor o azul./ E descobriu que uma casca vazia de cigarra esquecida no tronco das árvores só presta para poesia./ Que justamente aquela árvore na qual meu irmão se transformara, envaidecia-se quando era nomeada para o entardecer dos pássaros./ E tinha ciúmes da brancura que os lírios deixavam nos brejos. Meu irmão agradeceu a Deus aquela permanência em árvore porque fez amizade com muitas borboletas. [EF 63].

Tratado geral das grandezas do ínfimo foi lançado em 2001 e, pelo título, anuncia-se o foco do seu conteúdo: o minúsculo. Ele é perseguido ao longo de toda a obra, já que o olhar do sujeito poético, entre o menor e o maior, opta pelo primeiro:

SOBRE IMPORTÂNCIAS

Uma rã se achava importante/ Porque o rio passava nas suas margens./ $O$ rio não teria grande importância para a rã/ Porque era o rio que estava ao pé dela./ Pois Pois. [...] Em Roma, o que mais me chamou atenção foi um prédio que ficava em frente das pombas./ O prédio era de estilo bizantino do século IX. Colosso!/ Mas eu achei as pombas mais importantes do que o prédio. Agora, hoje, eu vi um sabiá pousado na Cordilheira dos Andes./ Achei o sabiá mais importante do que a Cordilheira dos Andes./ [...]. [TGGI - 35]. 
A capa é de Martha Barros.

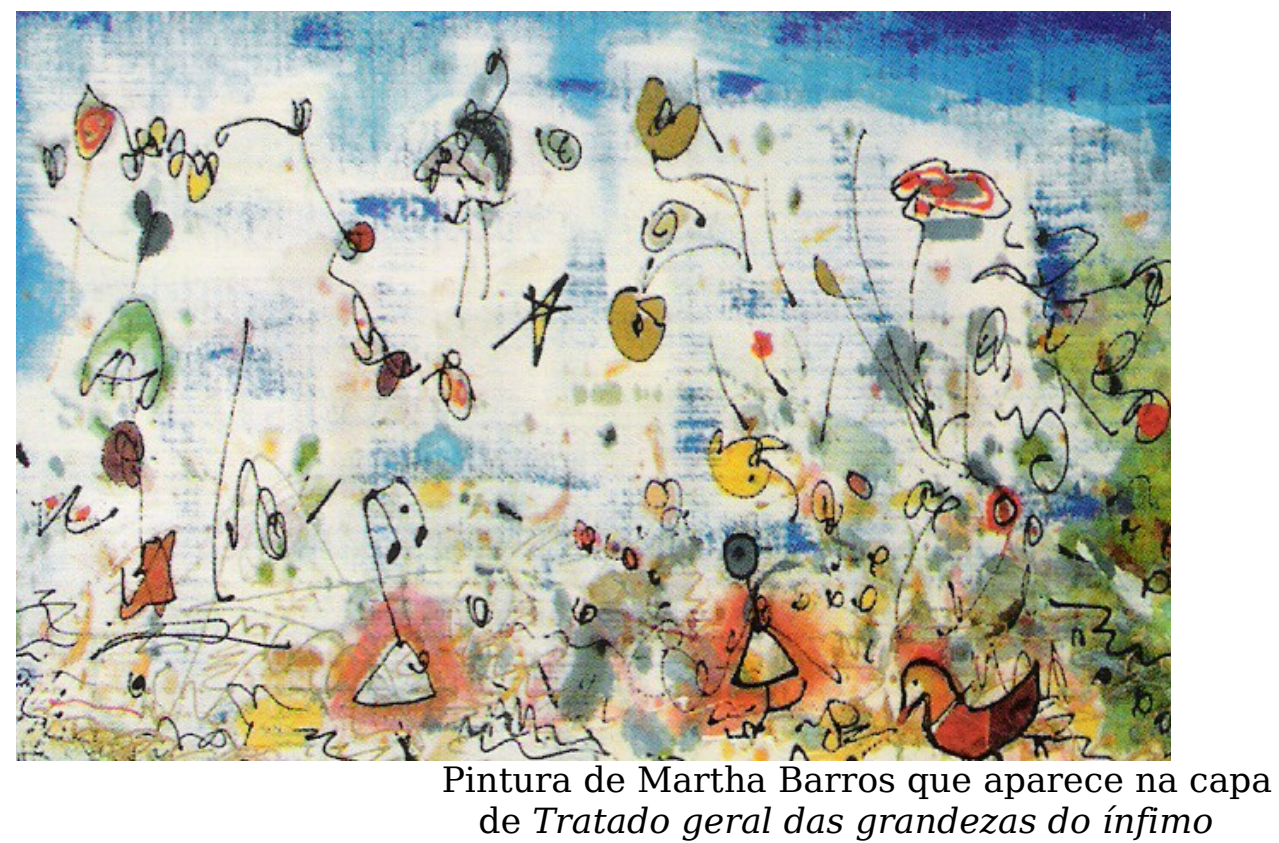

A idéia da exaltação dos elementos ínfimos, proposta no título da obra, foi apreendida pela artista que povoou uma tela ampla com pequenos pontos e rabiscos. As imagens da artista lembram um pouco, no caso, "A máquina de chirear", de Paul Klee.

O leitor deve ler os textos de Tratado... com os ouvidos, como este poema pleno de aliteração e no qual Bach é citado:

\section{DE PASSARINHOS}

Para compor um tratado sobre passarinhos

$\bar{E} \_$preciso por primeiro que haja um rio com árvores

e palmeiras nas margens.

E dentro dos quintais das casas que haja pelo menos

goiabeiras.

E que haja por perto brejos e iguarias de brejos. É preciso que haja insetos para os passarinhos. Insetos de_pau sobretudo que são os mais 
palatáveis.

A presença de libélulas seria uma boa.

$O$ azul é muito importante na vida dos passarinhos

Porque os passarinhos precisam antes de belos ser

eternos.

Eternos como uma fuga de Bach. [TGGI - 13].

Assim, o silêncio da escuta é fundamental nessa obra e, em um detalhe, do quadro de Martha Barros que está na capa há a personificação de uma nota musical.

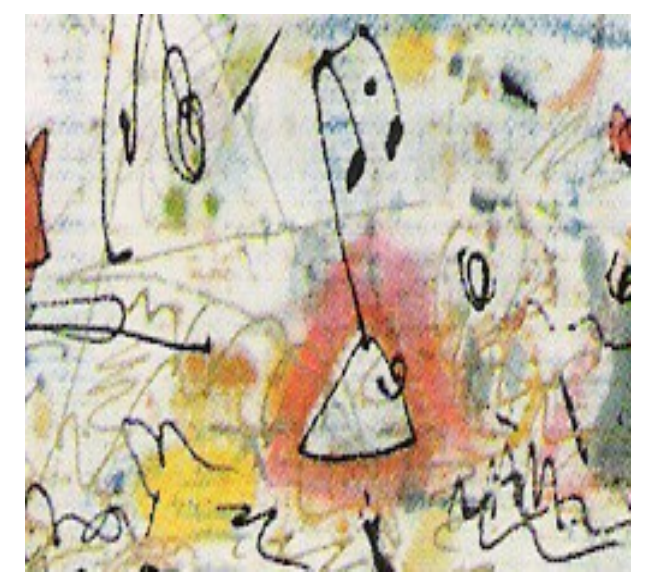

Detalhe da capa de Martha Barros para Tratado...

Um autor extremamente interessado no silêncio da escuta é citado: Antônio Vieira. O orador português tinha facilidade para aprender "de ouvido" as línguas dos índios e dos africanos no Brasil. Ele é mencionado neste poema:

\section{POIS POIS}

O Padre Antônio Vieira pregava de encostar as orelhas

Na boca do bárbaro.

Que para ouvir as vozes do chão

Que para ouvir a fala das águas 
Que para ouvir o silêncio das pedras

Que para ouvir o crescimento das árvores

$E$ as origens do Ser. Pois Pois.

Bernardo da Mata nunca fez outra coisa

Que ouvir as vozes do chão

Que ouvir o perfume das cores

Que ver o silêncio das formas

E o formato dos cantos. Pois pois.

Passei muitos anos a rabiscar, neste caderno, os

Escutamentos de Bernardo.

Ele via e ouvia inexistências.

Eu penso agora que esse Bernardo tem cacoete

para

Poeta. [TGGI - 47].

A importância do silêncio da escuta é muito grande e a audição se confunde com os outros sentidos, mostrando a amplitude dos escutamentos de Bernardo, muito próximos aos dos índios, afinal o sujeito poético quer ouvi-los, como Antonio Vieira.

Um outro autor que valorizou o silêncio audiente é mencionado nesse Tratado...: João Guimarães Rosa:

TRIBUTO A J. G. ROSA

Passarinho parou de cantar.

Essa é apenas uma informação.

Passarinho desapareceu de cantar.

Esse é um verso de J. G. Rosa.

Desapareceu de cantar é uma graça verbal.

Poesia é uma graça verbal. [TGGI - 23].

Crianças têm uma linguagem mais próxima da poesia, na obra de Barros e de Rosa, e esse dizer inclui a graça verbal, indicada em "Tributo a J. G. Rosa”, o que pode ser entendido como o humor que se tira das palavras ou $o$ abençoamento místico via verbo, sendo ambos os sentidos muito comuns nas obras de ambos os autores. Tais significados estão presentes em "Aletria e hermenêutica", prefácio rosiano de Tutaméia: Uma anedota é como um fósforo: riscado, deflagrada, foi-se a serventia. Mas sirva talvez ainda a outro emprego a já usada, qual mão de indução ou por exemplo instrumento de análise, nos tratos da poesia e da transcendência. Nem será sem razão que a palavra "graça" 
guarde os sentidos de gracejo, de dom sobrenatural, e de atrativo. [...]. [Rosa, 2001, p. 29].

Rosa afirma inclusive que comicidade e humorismo podem atuar como catalisadores ou sensibilizantes ao alegórico espiritual. [Rosa, 2001, p. 29].

Também em 2001, é publicado apenas no Estado de Mato Grosso do Sul o livro Águas. A obra é belamente ilustrada por Edvaldo Jacinto Correia.

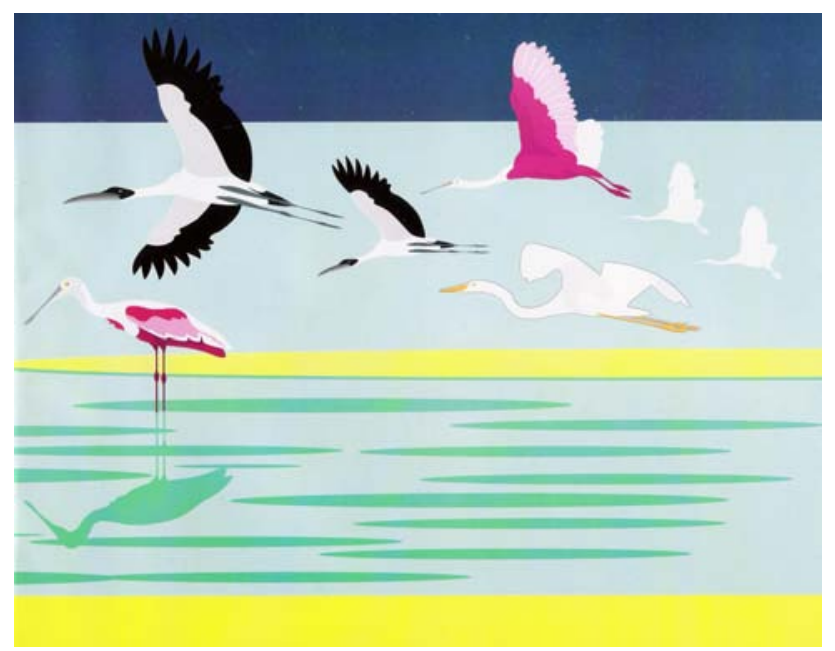

Pássaros do pantanal,

ilustrados por Edvaldo Jacinto Correia, no livro Águas.

As imagens preponderam, sendo o texto bastante diminuto como se vê a seguir, na íntegra:

Desde o começo dos tempos águas e chão se amam. Eles se entram amorosamente e se fecundam. Nascem formas rudimentares de seres e de plantas/ Filhos dessa fecundação. Nascem peixes para habitar os rios/ $E$ nascem pássaros para habitar as árvores. Águas ainda ajudam na formação das conchas e dos caranguejos. As águas são a epifania da Natureza. Agora penso nas águas do Pantanal/ Nos nossos rios infantis/ Que ainda procuram declives para correr. Porque as águas deste lugar ainda são espraiadas para o alvoroço dos pássaros. Prezo os espraiados destas águas com as suas beijadas garças. Nossos rios precisam de idade ainda para formar os seus barrancos. Para pousar em seus leitos. Penso com humildade que fui convidado para o banquete destas águas. Porque sou de bugre. Porque sou de brejo. Acho que as águas iniciam os pássaros. Acho que as águas iniciam as árvores e os peixes. E 
acho que as águas iniciam os homens. Nos iniciam. E nos alimentam e nos dessedentam. Louvo esta fonte de todos os seres, de todas as plantas, de todas as pedras. Louvo as natências do homem do Pantanal. Todos somos devedores destas águas. Somos todos começos de brejos e rãs. E a fala dos nossos vaqueiros carrega murmúrios destas águas. Parece que a fala de nossos vaqueiros tem consoantes líquidas E carrega de umidez as suas palavras. Penso que os homens deste lugar são a continuação destas águas.

Se Águas é uma obra para ver, há uma outra, do mesmo ano, 2001, que é para escutar: é o CD "Manoel de Barros por Pedro Rangel e Manoel de Barros", que é o volume oito da "Coleção poesia falada", lançada pela Luz da Cidade Produções Artísticas Fonográficas.

Escritos de vários tempos podem ser ouvidos pela voz do seu autor e, preponderantemente, pela voz do ator Pedro Rangel, que oferece às palavras manoelinas um sotaque carioca. No caso de Barros, o sotaque carioca também está presente, já que ele morou no Rio de Janeiro, mas ele se mistura ao modo pantaneiro de falar.

O CD tem trilha sonora de Renato Piau e foi idealizado e produzido por Paulinho Lima. Há, nele, um comentário de Walter Lima Júnior, que se serve de expressões manoelinas dos livros Retrato do artista quando coisa e $O$ livro das ignorãças, dos quais pertencem a maioria dos textos lidos: O produtor Paulinho Lima não poderia ter escolhido melhor voz e sensibilidade que a de Pedro Paulo Rangel para "corromper o silêncio das palavras", de Manoel de Barros, o poeta que enxerga o cheiro do sol. A intimidade do ator com o dizer nos restitui a paisagem de pequenas criaturas, de latas tristes, de rios que são cobras de vidro, do ínfimo que habita o quintal pantaneiro deste aventuroso Manoel desregulador da natureza. [Lima Júnior, no encarte do CD].

Também em 2001, os "Poeminhas pescados numa fala de João" são republicados como um texto para crianças, ganhando ilustrações de Ana 
Raquel $^{17}$. Ao final dessa edição, aparece esta desexplicação de Barros: Língua de criança é a imagem da língua primitiva/ $\mathrm{Na}$ criança fala o índio, a árvore, o vento/ $\mathrm{Na}$ criança fala o passarinho [...]/ $\mathrm{Na}$ criança os musgos desfalam, desfazem-se/ Os nomes são desnomes/ [...]/ A língua das crianças conta a infância em tatibitati e gestos. [PPFJ - sem paginação].

Em 2001, é publicado o livro infantil O fazedor de amanhecer, com capa e ilustrações de Ziraldo. Em um trecho da obra, lê-se: Só o silêncio faz rumor no vôo das borboletas. Esse verso ganha uma ilustração de Ziraldo que evidencia o silêncio da escuta:

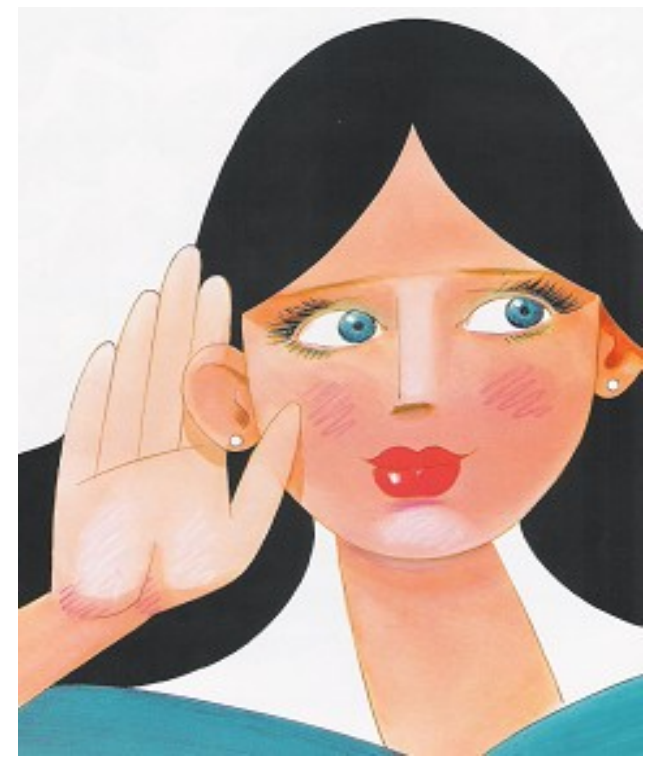

Ilustração de Ziraldo

Todo o livro é pleno de ilustrações, presentes inclusive na capa, mas há uma exceção: Ziraldo não apresenta nenhuma imagem para este poema: Com as palavras se podem multiplicar os silêncios. O artista plástico representa esses silêncios com uma página de fundo branco.

Em 2002, é lançado um pequeno livro de Barros pela Eraodito Editora, que faz parte da Coleção 5 minutinhos. São obras para serem lidas em torno de 30 segundos, sem serem comercializadas. O título é justamente 30 segundos. A coleção conta com outros autores como Glauco Mattoso, Moacyr Scliar, Fernando

17 O texto publicado em Compêndio... é praticamente o mesmo reeditado como Poeminhas pescados numa fala de João, pois ocorre apenas uma alteração: o acréscimo destes versos: $A$ noite caiu da árvore./ Maria pegou ela pra criar/ e ficou preta... [PPFJ - sem paginação]. 
Bonassi e João Gilberto Noll, entre outros. Em seu livrinho, Barros celebra a pequenez: Dou importância às miudezas./ Sou um apanhador de desperdícios/ que nem as boas moscas. [TS - sem paginação].

Memórias inventadas: a infância é obra publicada em 2003; conciliando recordação e ficção, uma voz conta uma experiência infantil inesquecível:

\section{“Parrrede!"}

Quando eu estudava no colégio, interno, Eu fazia pecado solitário.

Um padre me pegou fazendo.

-Corrumbá, no parrrede!

Meu castigo era ficar em pé defronte a uma parede e

Decorar 50 linhas de um livro.

O padre me deu pra decorar o Sermão da Sexagésima de Vieira.

- Decorrar 50 linhas, o padre repetiu.

$O$ que eu lera por antes naquele colégio eram romances de aventura, mal traduzidos e que me davam tédio.

Ao ler e decorar 50 linhas da Sexagésima fiquei

Embevecido.

E li o Sermão inteiro.

Meu Deus, agora eu precisava fazer mais pecado solitário!

E fiz de montão.

- Corumbá, no parrrede!

Era a glória.

Eu ia fascinado pra parede.

Desta vez o padre me deu o Sermão do Mandato.

Decorei e li o livro alcandorado

Aprendi a gostar do equilíbrio sonoro das frases.

Gostar quase até do cheiro das letras.

Fiquei fraco de tanto cometer pecado solitário.

Ficar no parrede era uma glória.

Tomei um vidro de fortificante e fiquei bom.

A esse tempo também eu aprendi a escutar o silêncio das paredes. [MII - sem paginação].

O que seria punição para o menino, vindo de Corumbá, acaba se tornando fonte de fruição tão intensa quando a do "pecado solitário". A quietude da leitura se associa ao silêncio das paredes ouvido pelo sujeito poético. A inarticulabilidade da escuta tem inclusive destaque no "Sermão da 
sexagésima", de Vieira, citado nesse texto. O orador português que se mostrou um bom ouvinte, em se tratando de línguas estrangeiras, já que aprendeu rapidamente o tupi e línguas africanas, também mostra que tem o ouvido fino com relação aos pregadores do evangelho. Mostra que se a Igreja não tem muitos adeptos é porque algum problema há ou com o orador ou com os ouvintes.

Em Memórias inventadas: a infância, Barros retoma várias passagens da sua primeira obra, Poemas concebidos sem pecado, e as comenta. Os trechos do livro iniciante rememorados no mais recente são justamente os que mostram a fala popular:

\section{CABELUDINHO}

Quando a Vó me recebeu nas férias, ela me apresentou aos amigos: Este é meu neto. Ele foi estudar no Rio e voltou de ateu. Ela disse que eu voltei de ateu. Aquela preposição deslocada me fantasiava de ateu. Como quem dissesse no Carnaval: aquele menino está fantasiado de palhaço. Minha avó entendia de regências verbais. Ela falava de sério. Mas todo-mundo riu. Porque aquela preposição deslocada podia fazer de uma informação um chiste. E fez. E mais: eu acho que buscar a beleza nas palavras é uma solenidade de amor. E pode ser instrumento de rir. De outra feita, no meio da pelada um menino gritou: Disilimina esse, Cabeludinho. Eu não disiliminei ninguém. Mas aquele verbo novo trouxe um perfume de poesia à nossa quadra. Aprendi nessas férias a brincar de palavras mais do que trabalhar com elas. Comecei a não gostar de palavra engavetada. Aquela que não pode mudar de lugar. Aprendi nessas férias a brincar de palavras pelo que elas entoam do que pelo que elas informam. Por depois ouvi um vaqueiro a cantar com saudade: $A i$ morena, não me escreve/ que eu não sei a ler. Aquele a preposto ao verbo ler, ao meu ouvir, ampliava a solidão do vaqueiro. [MII - sem paginação].

Em 2003, é publicado Cantigas por um passarinho à toa, no qual o enunciador quer saber as canções do vento nas folhas da tarde e mostra que um senhor um pouco louco deseja transcrever para flauta/ o canto dos vermes. 
Afirma ainda que tudo que os livros ensinavam ele já aprendera nos espinhos e nas fontes. O silêncio das borboletas tem sua força: Vi uma borboleta/ sentada nos braços da manhã./ Ela estava parada/ embaixo de outra borboleta./ Não faziam barulho/ Nem piscavam./ Só o vento arregaça as saias delas. [CUPT - sem paginação].

Na quarta capa do livro Barros comenta sobre a arte de sua filha, Martha Barros, ilustradora daquele livro: A linguagem desta pintora é metafórica. Ela faz metáfora de pássaros, de peixes, de conchas, de sapos. E muitas descoisas. Imagens trazidas por rastros de suas memórias afetivas. Martha trabalha com técnicas de acrílico sobre telas, e sobre tecidos em trapos, pedaços de sacos de aniagem, restos de feltro de chapéus velhos e outras superfícies que busca nos porões. Usa cores que me fazem lembrar dos índios Terenos. Eles faziam metáfora também de suas cores. Vermelho era sangue de arara; verde, sangue de folha; amarelo, sangue de sol; e azul, sangue do céu. A linguagem desta pintora tem um estilo rigorosamente pessoal. Martha não copia a natureza, ela desfigura os seres e as coisas. Martha faz descoisas com encantamento de poeta. (Manoel de Barros, outubro de 2001).

Em 2004, surgem os Poemas rupestres, em que, como o título já aponta, reina a despalavra associada aos desenhos das cavernas: A gente pintava nas pedras a voz. [PR - 21].

O mutismo pantaneiro é mostrado, num contexto em que a fauna busca sua sobrevivência:

\section{CREME}

Sucuri pegou um bezerro/ E deu um forte abraço nele./ Foi se enrolando no corpo/ do bezerro/ Foi apertando o abraço apertando/ Até quebrar todo osso do bezerro./ $O$ bezerro virou um creme. Eu estava perto. Eu assisti. O silêncio do bezerro nem mexia./ Depois a cobra engoliu o creme. [PR - 63].

A suspensão do silêncio também é apresentada:

\section{O COPO}

Estava o jacaré na beira do brejo tomando um copo de sol.

Foi o menino 
E tascou uma pedra

No olho do jacaré.

O bicho soltou três urros

E quebrou o silêncio do lugar.

Os cacos do silêncio ficaram espalhados

na praia.

O copo de sol não rachou nem. [PR - 67].

Em 2006, é publicada a continuidade das Memórias inventadas com o subtítulo de a segunda infância. No livro, persegue-se a busca de uma linguagem mais próxima do silêncio primevo: Rogaciano era índio Guató. [...]. Uma hora me falou que não sabia ler nem escrever. Mas seu avô que era o Chamã daquele povo lhe ensinara uma Gramática do Povo Guató. Era a Gramática mais pobre em extensão e mais rica em essência. Constava de uma só frase: Os verbos servem para emendar os nomes. E botava exemplos: Bentevi cuspiu no chão. $O$ verbo cuspir emendava o bentevi com o chão. [...] Ao fim me pareceu tão sábio o Chamã dos Guatós quanto Sapir. [MISI - sem paginação].

Em dezembro de 2006, mês em que Manoel completou noventa anos, a revista Caros Amigos publicou este poema inédito de Barros:

\section{UM SONGO}

Aquele homem falava com as árvores e com as/ águas/ ao jeito que namorasse./ Todos os dias/ ele arrumava as tardes para os lírios dormirem./ Usava um velho regador para molhar todas as/ manhãs os rios $e$ as árvores da beira./ Dizia que era abençoado pelas rãs $e$ pelos/ pássaros./ A gente acreditava por alto./ Assistira certa vez um caracol vegetar-se/ na pedral mas não levou susto./ Porque estudara antes sobre os fósseis/ lingüísticos/ e nesses estudos encontrou muitas vezes caracóis/ vegetados em pedras./ Era muito encontrável isso naquele tempo./ Até pedra criava rabo! A natureza era inocente.

P. S.:

Escrever em Absurdez faz causa para poesia/ Eu falo e escrevo Absurdez. Me sinto emancipado. [Barros, 2006, p. 29].

Nesse escrito, no silêncio das entrelinhas, pode-se perceber a busca do 
mutismo pré-verbal alojado nesse caracol vegetado na pedra, que consta nos fósseis lingüísticos. Também, nessa publicação, são apresentadas três entrevistas do escritor; em uma delas, Barros fala do seu olhar e do seu ouvir, ligados ao local de seu nascimento: Pantanal é o lugar da minha infância. Recebi as primeiras percepções do mundo no Pantanal. Meu olhar viu primeiro as coisas do Pantanal. Minhas ouças ouviram primeiro os ruídos do mato. [Barros, 2006, p. 29]. .

Em uma outra declaração, relacionada ao silêncio da escuta, Manoel afirma que, na Itália, ouvia, nas igrejas, Bach, Beethoven e música barroca. Em seguida, surge essa pergunta: Os poetas só gostam de música erudita? A resposta é: Não, gosto de tudo. Chico, Paulinho da Viola, tudo que toca. [Barros, 2006, p. 29].

Em 2007, surge o livro infantil Poeminha em língua de brincar, que conta a história de um menino que falava em língua de ave e dispensa pensar. Ele também aprendera no Circo, há idos, que a palavra tem/ que chegar ao grau de brinquedo/ Para ser séria de rir. [PLB - sem paginação].

Um tema recorrente na obra de Barros - e que pode associar-se ao silêncio - é retomado nessa obra para o público mirim: O menino sentenciou:/ Se o Nada desaparecer a poesia acaba. [PLB - sem paginação].

******

Na obra de Barros nem o nada, nem os mutismos desaparecem, por serem fundamentais.

Silêncios muitos os de Manoel, que na sua polissemia revelam facetas várias da vida, dos seres, das coisas. Entre o silêncio do cosmos e o silêncio do Pantanal, vigora o mudo diálogo com o enigma e a simplicidade, com as tragédias históricas (como a guerra) e o tempo primevo, com o erudito e o popular. 


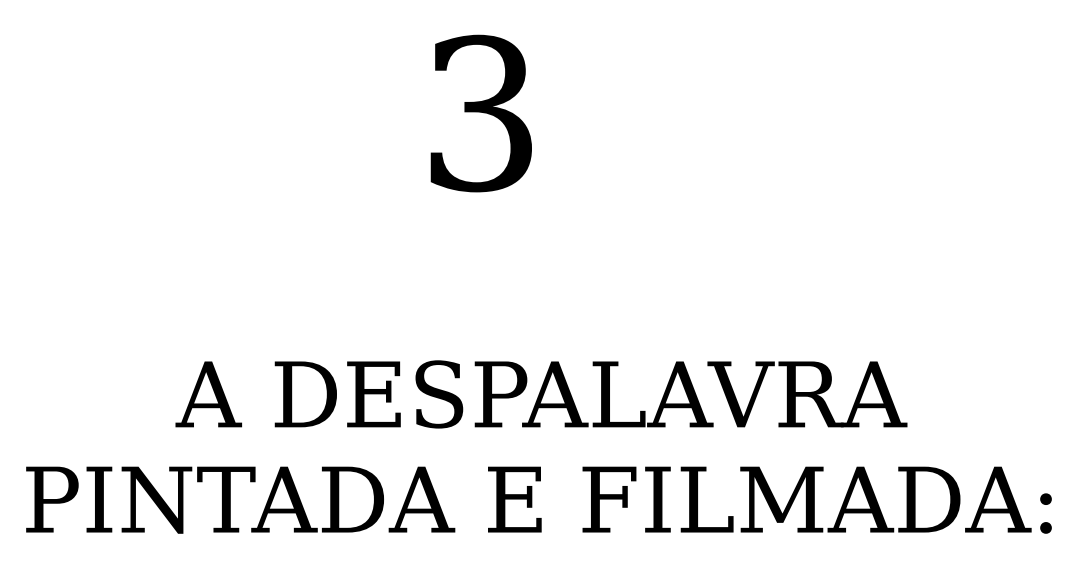

RETRATO DO ARTISTA QUANDO COISA

(1998) 
Passo eu a navalha na noite fatiando o que não vi/

Esse filme eu já vi./[...]. Anoiteceu na minha garganta/ Um mistério afogado frente à luz. Esse filme eu não vi.

["Tô na rua", 
de Luis Melodia, do seu CD "Retrato do artista quando coisa"].

\title{
QUIETOS QUADROS
}

\author{
pulou/ pairou como um poema/ \\ verteu com seu dilema/ \\ do último andar/ caindo focou cada janela/ \\ enquadre e fotogramas/ [...]/ \\ lembrou/ de toda a sua história/ \\ molduras da memória/ a todo e cada andar/ \\ sorriu/ gostou de cada cena daquele zencinema/ \\ seus olhos a filmar \\ ("Zencinema", de Hilton Raw e Arnaldo \\ Black, música do CD homônimo de Tetê
} Espíndola).

Retrato do artista quando coisa é livro de 1998 e está dividido em duas partes: a primeira é homônima à obra e a segunda é "Biografia do orvalho". A epígrafe da primeira seção é de Fernando Pessoa, Não ser é outro ser [RAQC 9], que pode ser entendido como um repensar do ser ou não ser, eis a questão shakespeareano. A dúvida que é elemento chave dessa e de outras falas de Hamlet surge também nesse livro manoelino. Em um poema no qual o sujeito poético se propõe a esclarecer seu discurso, já que quer corromper o silêncio das palavras [RAQC - 13], aparece um verso em itálico e, entre parênteses, a sua explicação que teoricamente vem tirar as dúvidas do leitor sobre seu sentido. No entanto, a explicação desexplica e, especificamente, o comentário do terceiro verso não elimina o questionamento, mas traz novas interrogações:

3. Os jardins se borboletam. (Significa que os jardins se esvaziaram de suas sépalas e de suas pétalas? Significa que os jardins se abrem agora só para o buliço das borboletas?). [RAQC - 13].

Machado de Assis, aparece na epígrafe da segunda seção de Retrato do artista quando coisa: Para encontrar o azul eu uso pássaros/ As letras se fizeram para frases. [RAQC - 57].

Apreciador do silêncio das entrelinhas e ótimo criador de imagens, 
Machado surge aqui com uma citação bastante imagética e que suscita a idéia de que para chegar a um ponto específico passa-se por outro diferente. Seria o caminho das metáforas? Ou das armadilhas verbais que confundem o leitor? Seja qual for a resposta, é importante observar que os silêncios aliados à ambigüidade e às mensagens do subtexto estão presentes tanto na obra machadiana quanto na manoelina.

A obra de Machado está plena de alusões ao mutismo da escuta, como se viu no primeiro capítulo, nas audições de D. Paula, por exemplo. Esse tipo de silêncio está presente no Retrato..., de Barros, num poema em que a frase machadiana volta a aparecer: Deus disse: Vou ajeitar a você um dom:/ Vou pertencer você para uma árvore./ E pertenceu-me./ Escuto o perfume dos rios./ Sei que a voz das águas tem sotaque azul./ Sei botar cílio nos silêncios./ Para encontrar o azul eu uso pássaros./ Só não desejo cair em sensatez./ Não quero a boa razão das coisas./ Quero o feitiço das palavras. [RAQC - 61].

São mencionados, diretamente, no manoelino Retrato..., Camões, Casimiro de Abreu, Kant, Darwin, Francis Ponge, Roquete-Pinto; mas a força do diálogo desse poeta com outros autores está no silêncio, ou seja, as relações do seu texto com outras obras se fazem no subtexto.

O só sei que nada sei, de Sócrates, por exemplo, parece ser recuperado nesse verso com sentido próximo: $O$ que resta de grandezas para nós são os desconheceres. [RAQC - 35].

Em outro poema do livro, Guimarães Rosa é citado:

Levei o Rosa na beira dos pássaros que fica no meio da Ilha Lingüística.

Rosa gostava muito de frases em que entrassem

Pássaros.

E fez uma na hora:

A tarde está verde no olho das garças.

E completou com Job:

Sabedoria se tira das coisas que não existem

A tarde verde no olho das garças não existia

Mas era fonte do ser.

Era poesia.

Era o néctar do ser.

Rosa gostava muito do corpo fônico das palavras.

Veja a palavra bunda, Manoel

Ela tem um bonito corpo fônico além do propriamente.

Apresentei-lhe a palavra gravanha. 
Por instinto lingüístico achou que gravanha seria Um lugar entrançado de espinhos e bem emprenhado de filhotes de gravatá por baixo E era.

O que resta de grandezas para nós são os desconheceres - completou.

Para enxergar as coisas sem feitio

É preciso ao saber nada.

É preciso entrar em estado de árvore.

É preciso entrar em estado de palavra.

Só quem está em estado de palavra pode enxergar as coisas sem feitio. [RAQC -35].

O verde do mato que parece estampar-se nos olhos dos pássaros gerou muita prosa para Guimarães, vide as descrições dos vegetais em suas obras, como em "São Marcos", de Sagarana, por exemplo. São dessa mesma cor os olhos de Diadorim (que têm grande destaque em Grande sertão: veredas: Diadorim me segurou com os olhos) e a fita usada por uma menina que não tem chapeuzinho, muito menos vermelho, para ver a sua vó moribunda. O grande lobo, em "Fita verde no cabelo", é a morte que imobiliza a mulher idosa e a fita verde da menina fica no caminho, indicando um rito de passagem: ela tem que enfrentar o óbito com madureza e não mais com "verdez" infantil. Além disso, Nhinhinha, do conto "A menina de lá", de Primeiras estórias, pede que sejam verdes os enfeites brilhantes a serem colocados no seu caixão rosa, quando ela morrer.

É necessário pensar sobre o título dessa obra de Manoel de Barros, mas antes de refletir sobre quando um artista torna-se coisa, o que será feito na próxima seção, parece importante atentar para o vocábulo retrato, que também gerou poesia para Augusto Frederico Schimit:

\section{RETRATO}

Ele era da raça dos que suportam todo o peso da vida/ Era da raça dos que não se queixam/ Dos que sorriem diante do destino adverso/ Viveu em silêncio grandes horas amargas/ E ninguém conheceu as devastações/ $O$ efeito dos golpes que lhe foram vibrados, as suas ruínas, os seus deuses mutilados, os túmulos que estavam nele ninguém desvendou/ Tudo ficou escondido,/ Tudo ficou defendido pela sua máscara tranqüila/ No entanto, ninguém amou mais profundamente do que ele amou./ [...]./ A amargura não fermentou na sua alma/ $O$ ressentimento não 
dominou jamais/ A sua visão simples das coisas/ Ele era da raça dos heróis obscuros. [Schimit].

A moldura captura, então, esse homem que viveu em silêncio grandes horas amargas, mas não há só esse quadro: existe uma verdadeira galeria de outras obras, marcadas pelo pictórico, principalmente na prosa. Ricardo Iannace, em um dos capítulos de sua Tese de Doutorado, intitulada Retratos em Clarice Lispector: literatura, pintura e fotografia, mostra que, em literaturas de diversas línguas, a pintura e o pintor surgem como personagens principais. Só para citar alguns exemplos: O Retrato de Dorian Gray, de Oscar Wilde, $O$ retrato encantado, de Stéphane Mallarmé, $O$ retrato oval, de Edgar Allan Poe e $O$ retrato, de Mary Westmacott (pseudônimo de Agatha Christie), que foi traduzido por Clarice Lispector.

$\mathrm{O}$ Retrato do artista quando coisa, de Barros, dialoga com a novela "O retrato", de Nikolai Gógol. Nela, lê-se:

Após os tubarões, a arraia miúda. É tão difícil enumerá-los quanto recensear os incontáveis insetos que pululam no vinho azedado. Há aí velhas que rezam e velhas bêbadas. Outras que rezam e se embriagam ao mesmo tempo, velhas que reúnem tudo isso de uma forma que só Deus pode saber. Podemos vê-las arrastando-se como formigas, tristes farrapos humilhados, da ponte Kalindin até o quarteirão dos vendedores de roupas usadas, onde têm muita dificuldade de arranjar quinze copeques. Em resumo, uma ralé tão estropiada que o mais caridoso dos economistas renunciaria a melhorar sua situação. [Gógol, 2000, p. 126].

A proposta dessas velhas, principalmente das que ao mesmo tempo embedam-se e rezam, parece que é recuperada por Passo-Triste, em Retrato do artista quando coisa, já que tem um gosto entre beato e bêbado:

$O$ rio cortava a tarde pelo meio/ De um lado passeavam cavalos,/ De outro lado - Passo Triste, aves e borboletas./ Passo Triste tinha um gosto entre beato e bêbado./ Uma espécie de ascese moscal o perseguia. Andava favorável para coisas./ Pedra ser/ inseto ser era seu galardão./ Sua casa era guardada por aves do que ferrolhos./ Não tinha dente nem letras./ [...]./ Cachorros faziam poste nele./ Gostava de encantações do que informações./ Passo-Triste é 
meu Pastor./ Ele me guiará. (RAQC -43).

Há também o Retrato do artista quando velho, do irlandês Sean O’Faolain. Esse autor apresenta uma discussão sobre auto-retrato, contrastando o escrever e o pintar:

\begin{abstract}
Você me pede um auto-retrato? Muito bem. Neste caso devo pedir-lhe que me imagine agora em frente de um cavalete, minha mão direita pronta para delinear o primeiro esboço na tela vazia. E você deve também imaginar que estou num espelho a minha esquerda porque o que vou pintar é O retrato do artista quando velho. [...]. Sou, na verdade, um escritor de retratos... Um pintor de auto-retratos tem sempre a mesma idade que o modelo, enquanto o escritor de retratos sempre é mais velho, está sempre lembrando, sempre olhando para o caminho percorrido. E como tenho agora setenta e seis anos, posso voltar o olhar para um caminho muito longo. [O'Faolain, Sean. A portrait of the artist as an old man. Apud: Mutran, 2002, 93].
\end{abstract}

Se há diferenças na dimensão temporal de retratar no livro e retratar na tela, nos dois casos o olhar se evidencia, pois ambos, escritor e pintor, precisam mirar funda e agudamente o que querem representar.

Fausto Wolff, em "Retrato do Manoel quando poesia", texto-orelha do livro de Barros, afirma que o poeta cuiabano tem uma visão aguçada: tomávamos cachaça e ouvíamos o povo. Olhava para ele e pensava: "Este é o sujeito que vê uma letra e a entorta". [...] [a] letra que Manoel entortou [...] atiça nossa visão, nos redimensiona. [Wolff, 2004, orelha de RAQC].

Wolff aponta que a arte manoelina está mais próxima à dos pintores do que a de outros literatos: Manoel é incomparável; está longe dos demais poetas. Mais fácil compará-lo a Picasso e De Kooning, os grandes decompositores de artes plásticas que, como ele, des-essencializavam a forma até torná-la pura. [...]. Manoel inventa uma cor que não existe. [Wolff, 2004, orelha de RAQC].

Assim, esse retrato de Barros, com cores existentes e não existentes, apresentando decomposições ao estilo de Picasso e De Kooning, está bem próximo da pintura e do desenho, que estão presentes no livro, por intermédio da sensível mão de Millôr Fernandes. 
Retrato do artista quando coisa
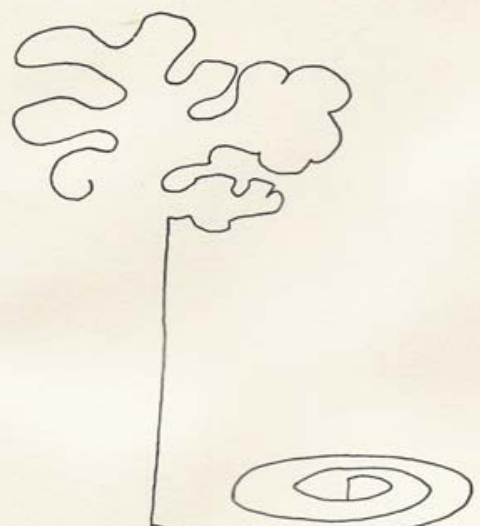

Biografia

do orvalbo

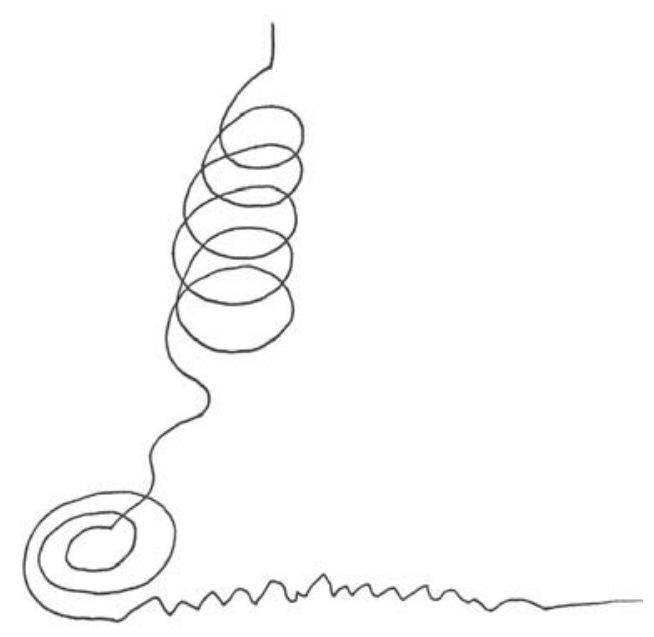

Desenhos de Millôr em Retrato... 
A imagem da primeira seção de Retrato... é uma árvore com raiz em espiral, mostrando a profundidade e o caráter cíclico da poesia de Barros.

Novamente a espiral aparece no desenho de Millôr para a segunda parte de Retrato..., apontando para seu caráter cíclico e mítico. A parte de baixo do desenho lembra o fóssil de um peixe. As idéias de escavação e de busca de realidades primevas se evidenciam nessa obra e Millôr o notou.

Faço vaginação com palavras até meu retrato aparecer./ Apareço de costas. Esse trecho de um dos poemas de Retrato... parece ter inspirado Millôr na capa.

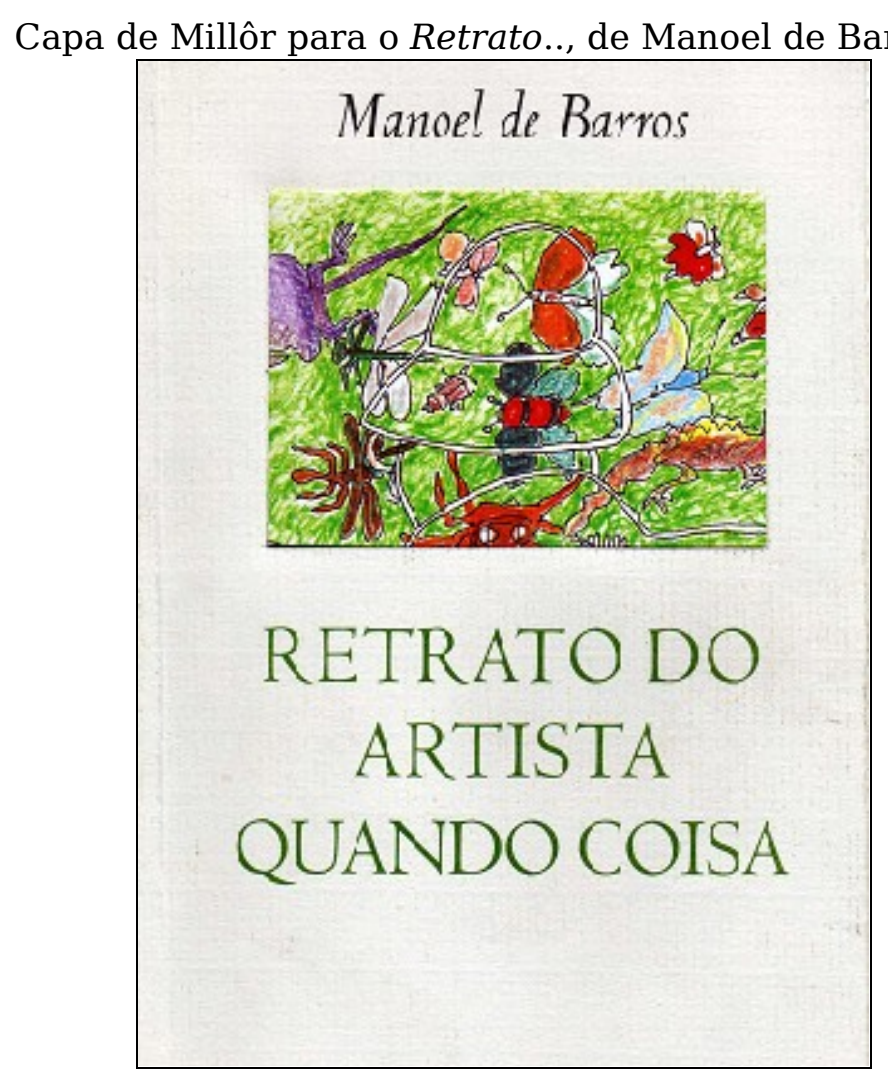

É possível ver na pintura de Millôr a figura de um homem, por meio dos seus contornos brancos; ele está de costas, de chapéu, com a cabeça voltada para a esquerda, usando óculos.

Vê-se um fundo verde exibindo várias borboletas, um besouro, um caranguejo e parte de animais indistinguíveis por causa da "moldura do quadro". São formas em que prepondera o vermelho, aparecendo também o 
amarelo, o violeta e vários tons de marrom.

Quando se vê a capa de Retrato... o impacto com seu colorido é grande, mas quando se abre o livro há uma surpresa maior: aquela ilustração vista inicialmente, nas molduras de um pequeno retângulo, agora se expande por uma página inteira com mais animais e cores: gafanhoto, sapo, lesma, tartaruga, peixe etc.

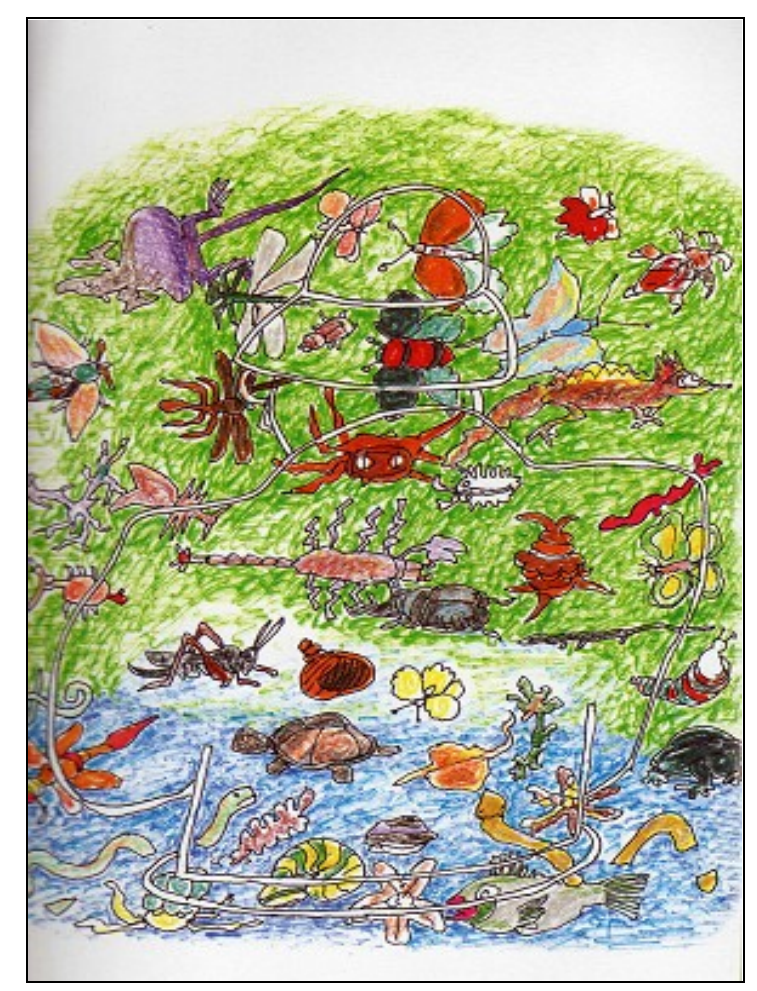

Aqui Millôr mostra, na arte pictórica, um tema importante da escrita de Barros: o artista que quer expressar o ilimitado de seus sentimentos e de sua visão mas tem que lidar com os entraves que a própria arte oferece: o limite das páginas, da moldura.

Se o verde preponderava diante dos limites da moldura da primeira capa, com a abertura do livro é o azul que se torna fundo de um pintado universo aquático com cobra, tartaruga, peixe, estrela do mar, arraia.

Assim, dentro do poeta quando coisa, há o verde do mato, o azul da água, o vermelho, o amarelo, o marrom e o violeta dos animais.

O sujeito poético manoelino, bem compreendido por Millôr, tem uma proposta parecida com a de Magritte, que usou as cores para retratar seres de costas. 

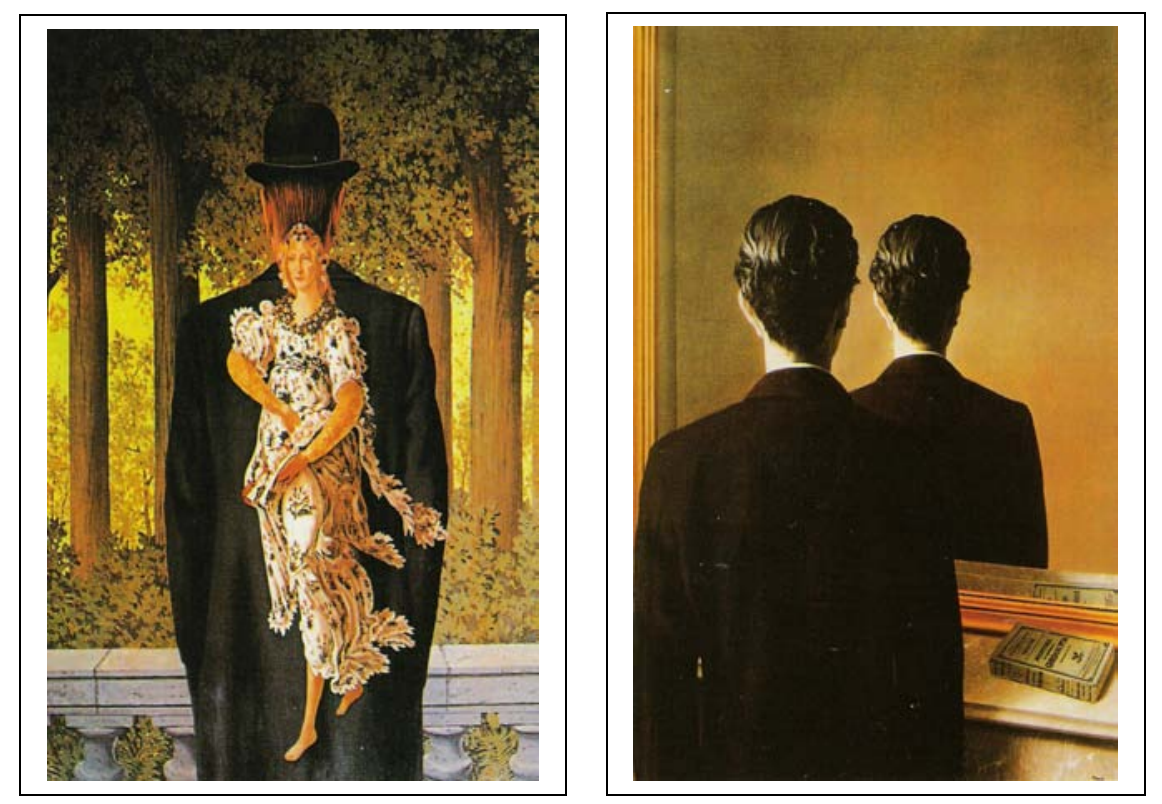

"O ramalhete perfeito" e "Proibida a reprodução (Retrato de Edward James)", de Magritte.

O manoelino Retrato do artista quando coisa dialoga, invevitavelmente, com o joyceano Retrato do artista quando jovem, que é obra de 1916, justamente o ano em que nasceu Barros. As coincidências biográficas entre ambos os autores são várias: estudaram em escola de padres, mas não se entregaram à vida eclesiástica por um motivo muito forte: desejavam ser artistas.

O autor cuiabano já na primeira obra, Poemas concebidos sem pecado, apontava:

5.No recreio havia um menino que não brincava/ com outros meninos/ $O$ padre teve um brilho de descobrimento nos olhos/ - POETA!/ O padre foi até ele: / - Pequeno, por que não brinca com os seus colegas?/ - É que estou com uma baita dor de barriga desse feijão bichado.

6. Carta acróstica:

"Vovó aqui é Tristão

Ou fujo do colégio

Viro poeta

Ou mando os padres...

Há muitas coincidências entre o retrato manoelino e o joyceano, mas há diferenças: o livro do autor brasileiro tem muito mais apelos ao mutismo do 
que o do escritor irlandês.

Os silêncios me praticam, afirma o sujeito poético de Retrato do artista quando coisa, que se propõe a destacar as inarticulabilidades, como uma mulher que coloca cílios postiços para valorizar os olhos: Deus disse: Vou ajeitar a você um dom:/ Vou pertencer você a uma árvore./ E pertenceu-me./ Escuto o perfume dos rios. Sei que a voz das águas tem sotaque azul./ Sei botar cílio nos silêncios. [...]. [RAQC - 61].

Na obra joyceana, há um momento em que o silêncio aparece, gerando incômodo no jantar da noite de Natal da família de Stephen Dedalus. Impera, assim, uma desagradável quietude, depois de uma seqüência de contendas verbais, ligadas a questões políticas e religiosas, envolvendo os que na mesa eram simpáticos ou antipáticos aos revolucionários pátrios, bem como aos padres:

O sr. Dedalus raspou com os trinchantes o fundo da travessa e disse:

- Aqui temos um saboroso pedaço a que damos o nome de nariz do papa. Se alguma das senhoras ou dos senhores...

Ergueu um pedaço de peru nos dentes do trinchante. Ninguém disse nada. Pô-lo então no seu prato, dizendo:

- Bem, já não poderão dizer que não ofereci. [...]. então, depois:

Enquanto ele comia ninguém falou. Disse

- Ora muito bem. E o dia conservou-se magnífico, apesar de tudo. Andou por aí uma porção de gente de fora.

Ninguém disse nada. E ele recomeçou:

- Creio mesmo que veio mais gente de fora do que no último Natal.

Olhou para os demais, cujos rostos estavam abaixados para os pratos; não obtendo resposta, esperou um momento, acabando por dizer amargamente:

- Está bem. O meu jantar de Natal, seja lá como for, ficou estragado. [Joyce, 1971, 32-33].

No restante da obra, é a palavra que tem força, não cedendo terreno ao silêncio. No quesito quantidade, inclusive, o verbo comparece mais amplamente em Joyce, com essa obra apresentada em forma de romance. 
Barros opta pela poesia, na qual insere elementos de prosa, mas elabora um livro bem menos extenso.

Com relação ao silêncio a obra manoelina está mais próxima a de um outro irlandês: Samuel Beckett, como se pode ver a seguir.

\section{DESDIZER EM REIFICAÇÃO}

Quem fala que sou hermético, é porque estou sempre elétrico.

Nada que se aproxima, nada me é estranho,

$$
[\ldots] /
$$

Seja pedra, seja planta, seja bicho, seja humano

["Olho de lince", de Jards Macalé e Wally Salomão].

\footnotetext{
Sentado sobre uma pedra estava o homem desenvolvido a moscas.

Ele me disse, soberano:

Estou a jeito de uma lata, de um cabelo, de um cadarço.

Não tenho mais nenhuma idéia sobre o mundo. Acho um tanto obtuso ter idéias. Prefiro fazer vadiagem com letras. Ao fazer vadiagem com letras posso ver quanto é branco o silêncio do orvalho. (RAQC -51).
}

Os dois primeiros versos desse poema são silenciosamente imagéticos: Sentado sobre uma pedra estava o homem desenvolvido a moscas. [RAQC -51]. 
Três imagens se fundem enigmaticamente: pedra, homem e moscas. O embrólio é dado a ver: os reinos da natureza se misturam ao observador desse "quadro", já que o ser humano parece uma extensão do reino mineral, representado pela pedra em que ele se sentou e, ao mesmo tempo, tem propriedades animais, já que é desenvolvido a moscas.

A idéia do homem que se reifica, já estava no livro Poesias, de Barros, de 1956; mais exatamente no conto "O encontro de Pedro com o nojo": Pedro estava só. Deixava-se completamente às coisas, recebendo suas emanações físicas. Pedro se encostava nas coisas, afagava-as como se elas fossem criaturas íntimas. Pedro era reconstruído. [P , in: PQT - 119].

O nome do personagem é muito revelador e em um trecho do texto ficam evidentes suas propriedades minerais: Pedro na pedra: Vai trôpego deitar-se nas pedras. [...]. A terra cheia de [...] pedras, - o atraía. [P , in: PQT - 119].

Pedro-pedra é parente do sujeito poético de Compêndio para uso dos pássaros: Bom era/ sobre um pedregal frio/ e limoso, dormir! [CUP, in: PQT 149].

Em "Anti-salmo por um desherói", poema de Gramática expositiva do chão, é dito, sobre esse homem sem qualidades, que seu amor o levara a pedra. [GEC, in: PQT - 158].

A mosca, que aparece no poema em análise, é tema de um outro escrito de Barros, do livro Tratado geral das grandezas do ínfimo:

Na beira da mosca

o céu parou

o dia parou.

Esse texto manoelino dialoga com um poema de Samuel Beckett:

A MOSCA

entre mim e a cena

a vidraça

vazia não fosse ela

ventre na terra

maltratada nos intestinos escuros

antenas enlouquecidas asas amarradas patas

em gancho boca a sugar o vazio

a espetar o azul dos céus a esmagar-se contra o

invisivel

com um frágil piparote ela cai 
mar e céu sereno [Beckett, s.d., sem paginação].

O inseto escolhido para tema é o mesmo, mas a extensão dos dois textos é contrastante: o escrito manoelino está mais condizente com a proporção da mosca, ou seja, ele é bem menor que o beckettiano. Há apenas dez palavras no poema do autor brasileiro enquanto aparecem cinqüenta e uma, no do escritor irlandês.

A busca do ínfimo é uma fixação de Barros e Beckett, no entanto, no caso de Manoel, ela está desde a primeira obra, com a escolha da poesia, como gênero, que mesmo mesclada a elementos da prosa nunca gerou livros longos. Em Livro sobre nada, uma constatação: a minha diferença é sempre menos.

Barros nunca escreveu um romance, o que Beckett fez várias vezes. E, como se um romance fosse pouco, Beckett escreveu uma trilogia: Molloy, Malone morre e $O$ inominável.

Uma divergência entre o escritor brasileiro e o autor irlandês: enquanto nos escritos de Beckett habita um pessimismo que apresenta seres e "terras devastadas", à moda eliotiana, existe nos textos de Barros um telurismo que colore de positividade a vida de seus cenários e entes, inclusive dos seus insetos.

Se no poema de Barros a mosca estava associada à imobilidade ( $N a$ beira da mosca/ o céu parou/ o dia parou), no de Beckett há o movimento do pequeno bicho nas suas antenas enlouquecidas e na sua boca a sugar o vazio. No entanto, a imobilidade acaba chegando a ele com a morte: com um frágil piparote ela cai.

O vazio e a morte, temas recorrentes na obra beckettiana, estão nesse seu escrito, mas não estão no de Barros. Apesar de haver vazio e haver morte nas obras manoelinas, elas não estão carregadas de negativismo como ocorre no caso do autor irlandês. É por isso que se comparados os dois poemas, percebe-se que o manoelino dispõe de uma positividade que falta no beckettiano. Um conteúdo místico pode ser notado no escrito do autor brasileiro (já que o céu pára diante da grandiosidade de sua criatura minúscula). Já no poema de Beckett, o céu se põe sereno e distante diante do 
piparote assassino. Em Retrato do artista quando coisa, as moscas não são alvo de piparotes e sim objeto de amor: Já posso amar as moscas como a mim mesmo. [RAQC - 11].

Além da fixação por insetos, como as moscas, há em Barros e Beckett o gosto pelo silêncio, inclusive, com destaque para uma de suas facetas: o indesignável:

Assim é que elas foram feitas (todas as coisas)-/sem nome./ Depois é que veio a harpa e a fêmea em pé./ [...]. Ficou certo pois não/ que as moscas iriam iluminar/ o silêncio das coisas anônimas./ Porém, vendo o Homem/ que as moscas não davam conta de iluminar o/ silêncio das coisas anônimas-/ passaram essa tarefa para os poetas. [CCASA - 49].

Pelas brechas dessa cosmogonia, nota-se que o princípio de tudo e todos está entranhado de silêncio. Daí, talvez, a necessidade de se iluminar o sem nome das coisas, trabalho que passou da competência das moscas para a dos poetas.

Nomes, sua arbitrariedade e até mesmo sua falta são verdadeiras fixações da obra beckettiana. A preocupação beckettiana com a ilegitimidade dos nomes já está presente no primeiro texto publicado do autor: "Dante... Bruno. Vico... Joyce", de 1929. Nesse ensaio, Beckett defende a originalidade da escrita de Joyce, principalmente porque este se prestava a revisar os nomes inadequados das coisas, criando outros: $O$ sr. Joyce de-sofisticou a linguagem. E deve-se comentar que nenhuma língua é tão sofisticada quanto o inglês. É mortalmente abstrata. Peguemos a palavra "dúvida" (doubt). Ela quase não nos dá nenhuma sugestão sensória de hesitação, da necessidade de uma escolha, de irresolução estática. Ao contrário do alemão "Szweifel", e em grau não menor o italiano "dubitare". O sr. Joyce reconhece o quanto "doubt" é inadequado para expressar um estado de extrema incerteza, e o substitui por "twosome twominds" .

Em Concerto a céu aberto para solos de ave, na possibilidade de dois nomes, o sujeito poético, com o dedo da poesia, aponta a sua opção: Não sei bem de que cor é a cor do amaranto./ Mas pelo "amar" e pelo "canto" fica bem esse/ amaranto aí (melhor do que se eu usasse/ perpétua, que é o outro nome que se põe a essa flor)./ Amaranto murmura melhor. 
Nesse caso, o sujeito poético prefere o amor e a canção contidos no nome amaranto e, para confirmar seu gosto por elementos amorosos e sonoros, usa

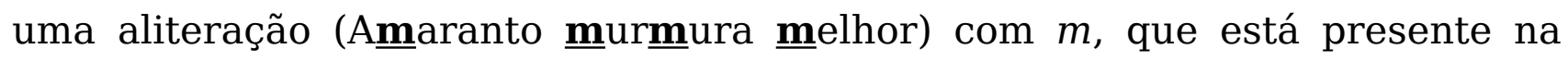
palavra amar. Além disso, a palavra amaranto rima com canto, o que não ocorre com perpétua.

Pululam comentários críticos e líricos sobre os nomes: Certas palavras têm ardimentos, outras não./ A palavra 'jacaré' fere a voz. É como descer arranhado pelas escarpas de um/ serrote./ É nome com verdasco de lodo no couro./ Além disso, é agríope (que tem olho medonho)./ Já a palavra 'garça' tem para nós um sombreamento de silêncios.../ E o azul seleciona ela!

Do mesmo modo como há o nome, existe também o desnome. Esse termo aparece em Retrato do artista quando coisa, o termo desnome aparece neste poema:

O lugar onde a gente morava era uma "Ilha
lingǘística", no jargão dos Dialetólogos (com o
perdão da má palavra). Isto seja: que a gente
morava em lugar isolado: núcleo de dez a vinte
pessoas, onde poderia germinar um idioleto.
[...]./ De novidade tinha por lá uma simpatia
para obter namoro. Era rabo de lagartixa
torrado. O pó se jogava nos cabelos da moça./
Na primeira poção a moça cede-diziam./ Mas a
Ilha Lingüística para nós ainda era um/
desnome.

Em Livro sobre nada, lê-se: sei de Baudelaire que passou muitos meses tenso porque não encontrava um título para os seus poemas. Um título que harmonizasse os seus conflitos. Até que apareceu Flores do mal. A beleza e a dor. Essa antítese o acalmou. (LN - 49).

Enquanto o nome não surgia, havia o silêncio do inominável, que pode estar associado também à sugestão das entrelinhas, ao silêncio do subtexto: Melhor que nomear é aludir.(LN - 68).

Antes de Manoel, Beckett já havia escrito o seu livro sobre nada: Nouvelles et textes pour rien. Nessa obra, está "O expulso", cujo narrador tem recorrentes sessões de amnésia com relação aos nomes: Ele me disse um nome de mulher que esqueci. [Beckett, 2006, p. 17]. Por outro lado, afirma que há nomes que são inesquecíveis, como o do senhor Nidder. 
O protagonista tenta por duas vezes descrever seu chapéu e desiste:

Como descrever esse chapéu? E por quê? [...]. Com a morte de meu pai poderia ter-me livrado do chapéu, nada mais se opunha a isso, mas nada fiz. Mas como descrevê-lo? Outra hora, outra hora. [Beckett, 2006, p. 7-8].

Essa passagem toca em uma questão bastante reiterada na obra beckettiana, a desistência de discorrer sobre algo, por causa da insegurança criada a partir do limite da linguagem que será usada.

A noção de limite da linguagem parece estar metaforizada neste poema de Retrato do artista quando coisa:

Uma formiga está de boca aberta para a tarde. As quatro patas da formiga tentam abraçar o sol./ $\mathrm{Na}$ verdade, não sei se são as patas da formiga que tentam abraçar o sol/ ou se são minhas frases que desejam fazer esse trabalho. (RAQC -59)

A idéia da pequenez da palavra diante do compromisso de expressar coisas grandiosas está presente; assim, ocorre a metáfora do limite com o qual o artista convive. No caso, o poeta é uma formiga, que tenta atingir, com suas patas (sua linguagem), algo mais amplo: o sol, ou seja a amplitude do seu mundo interior.

Em um trecho de "O expulso", de Beckett, lê-se:

Contentaram-se portanto, dessa vez, em me pôr na rua e pronto. [...]. Atravessei a rua e me voltei para a casa que acabava de me expelir, eu que jamais me voltava ao ir embora. Como era bonita! [...]. [Beckett, 2006, p. 6; 8-9].

Ou seja, sua morada passa a ser só o seu chapéu. Barros cria muitos seres em iguais condições:

\section{JOAQUIM SAPÉ}

Os ornamentos de trapo de Joaquim Sapé já estavam

criando cabelo de tão sujos.

Joaquim atravessava as ruelas da Aldeia como se

fosse

um Príncipe

Com aqueles ornamentos de trapo.

Quando entrava na Aldeia com o saco de lata às 
costas

Crianças o arrodeavam.

Um dia me falou, esse andarilho (eu era criança):

- Quando chove nos braços de uma formiga, o

horizonte diminui.

O menino ficou com a frase incomodando na cabeça.

Como é que esse Joaquim Sapé, que mora

debaixo

do chapéu, e que nem tem aparelho de medir céu, pode saber que os horizontes diminuem quando chove nos braços de uma formiga?

Se nem quase formiga tem braço!

Igual quando ele me disse que do lado esquerdo do sol voam mais andorinhas do que os outros pássaros?

Pois ele não tinha aparelho de medir o sol, como

Podia saber!

Ele seria um ensaio de cientista?

Ele enxergava prenúncios! [TGGI - 37, o grifo é meu].

Sapé, segundo o Dicionário Eletrônico Houaiss, é uma designação comum a algumas plantas da família das gramíneas, de que se usam os caules secos para cobrir casas.

Assim, esse ser sem casa tem esse nome que pode soar como ironia, recurso muito usado na obra beckettiana, mas parece que, nesse universo manoelino, tem sentido místico, porque a natureza presente no sapé está do lado de um nome de santo: Joaquim.

Um traço de distinção entre a obra beckettiana e a manoelina: Barros não escreveu seus textos em uma língua estrangeira, o que ocorreu várias vezes, no caso do escritor irlandês, que redigiu várias obras em francês como $O$ inominável.

Um trecho dessa obra beckettiana é usado como epígrafe de Concerto a céu aberto para solos de ave, de Manoel: Devo falar agora de mim, isso seria um passo na direção do silêncio...

Mutismo e estatismo aparecem conjugados nesse livro de Beckett. Tais elementos também se amalgama, no poema de Barros em análise: Sentado sobre uma pedra estava o homem. A pedra é mais silenciosa do que a mosca, com seu zinir e seus movimentos. Assim, quietez e imobilidade podem ser 
referências para esse homem-pedra, parente de um outro desse mesmo Retrato do artista quando coisa: Percebi que o homem sofria de uma enorme germinação de inércia. [RAQC - 37].

Estou a jeito de uma lata. A imagem da lata aparece na novela beckettiana "O fim": depois de ser expelido de seu lar, o narrador vai para as ruas, pega uma lata para pendurar no pescoço, para os passantes jogarem moeda. Depois desiste, encontra uma lata maior e coloca ao seu lado, para conseguir alguns trocados dos transeuntes.

A lata aparece também em Como é, de Beckett. Nesse escrito, aparece uma diferença importante entre o autor irlandês e Manoel de Barros: a violência física, quesito presente nos textos beckettianos e, em geral, ausente nos manoelinos. Em um trecho de Como é, lê-se:

Tudo com a mão direita [...] com a unha então do indicador direito gravo e quando ela quebra ou cai até crescer de novo com outra nas costas de Pim intactas no princípio da esquerda para a direita $e$ de cima para baixo como em nossa civilização gravo minhas maiúsculas romanas. [Beckett, p. 81].

A grafia dolorosa no corpo e outras violências em Como é não geram alarido, apenas gritos mudos [Beckett, p. 56], silêncios monstruosos [Beckett, p. 93] e preces sem palavras [Beckett, p. 104].

As latas estão presentes também em Fim de partida, que receberam o seguinte comentário de Adorno: As latas de lixo de Beckett são os emblemas de uma cultura restaurada depois de Auschwitz.

Dentro desses latões, estão Nagg e Nell, alijados de suas pernas. Beckett, em O inominável apresenta a força das mutilações gerada por tempos terríveis: meu próximo representante será um estropiado das pernas.

Barros, em uma entrevista, afirma:

Beckett expõe com crueldade seus vermes de chapéus, seus pedaços de gente. Seu efeito é a pungência em nós. [PQT - 328].

Os beckettianos pedaços de gente são parentes de Sabastião de Tratado geral das grandezas do ínfimo, que é um pedaço de pessoa:

O URUBUZEIRO 
Meu amigo Sabastião estourou a infância dele e mais duas pernas

No mergulho contra uma pedra na Cacimba da Saúde. Quarenta anos mais tarde Sabastião remava uma canoa

no rio Paraguaio

E deu o barranco de uma charqueada.

Sabastião subiu o barranco se arrastando como um caranguejo trôpego

Até a casa do patrão e pediu um trabalho.

$O$ patrão olhou para aquele pedaço de pessoa $e$ disse:

Você me serve para urubuzeiro.

(Urubuzeiro era tarefa de espantar os urubus que atentavam nos tendais de carne.)

Trabalho de Sabastião era espantar os urubus.

Sabastião espantava espantava espantava.

Os urubus voltavam de bandos.

Sabastião espantava espantava.

Um dia pegaram Sabastião a prosear em estrangeiro

com os urubus.

Chegou que Sabastião permitiu que os urubus

fizessem farra nas carnes.

Os urubus faziam farra e conversavam em estrangeiro

com Sabastião.

Veio o patrão e mandou Sabastião para o manicômio.

No manicômio ninguém compreendia a língua de

Sabastião

De forma que Sabastião despencou do seu normal

E foi encontrado na rua falando sozinho em estrangeiro. [TGGI - 21-22].

Os vermes de chapéus, mencionados por Barros, podem ser Didi, Gogo e Lucky de Esperando Godot, mas podem também ser Molloy, Moran, Malone e outros da trilogia Molloy, Malone morre e O inominável.

Há um outro tipo de silêncio que é explorado por ambos os autores: o do subtexto.

Na novela beckettiana "O expulso", o protagonista defende a sutileza: Eu já não tinha a permissão, a partir daquele dia de sair sem chapéu, com meus belos cabelos castanhos ao vento. [...]. Os jovens de minha idade, com quem eu 
era apesar de tudo obrigado a conviver de vez em quando, zombavam de mim. Mas dizia comigo, O chapéu não tem grande parte nisso, serve apenas de pretexto para suas piadas, como o ridículo mais óbvio, pois não são sutis. Sempre me surpreendi com a pouca sutileza dos meus contemporâneos, eu, cuja alma se contorcia da manhã à noite, na mera busca de si mesma. [Beckett, 2006, p. 8].

No poema em análise, lê-se: Ao fazer vadiagem com letras posso ver quanto/ é branco o silêncio do orvalho. [RAQC -51].

Esse silêncio branco pode estar associado ao subtexto, à silente vacância semântica do texto. O enunciador pauta-se, então, no não dito, como no poema de Barros, publicado no livro Poesias, intitulado "Zona hermética":

ZONA HERMÉTICA

De repente, intrometem-se uns nacos de sonhos; Uma remembrança de mil novecentos e onze; Um rosto de moça cuspido no capim de borco; Um cheiro de magnólias secas. O poeta/ Procura compor esse inconsútil jorro;/ Arrumá-lo num poema; e o faz. E ao cabo/ Reluz com a sua obra. Que aconteceu? Isto:/ O homem não se desvendou, nem foi atingido:/ $\mathrm{Na}$ zona onde repousa em limos/ Aquele rosto cuspido e aquele/ Seco perfume de magnólias,/ Fez-se um silêncio branco... (P- 112).

O mutismo hermético, nesse contexto, é associado à cor alva, talvez por lembrar lacuna, ou seja, o espaço em branco que será preenchido com as interpretações do leitor desse escrito. Mas o branco pode se associar à pintura já que é dito que o poeta se põe a compor esse inconsútil jorro, que é o rosto de uma moça e o cheiro de magnólias. Apela-se para a visão e o olfato nesse retrato poético que tem este resultado: o silêncio branco, que volta aparecer neste livro manoelino de 1998

O branco da poética de Barros acaba se associando ao branco da pintura de artistas modernos, porque, em geral, o autor, assim como esse tipo de pintor, silencia sobre os sentidos da sua arte. Existe, em Retrato..., mais a preocupação em criar imagens que devem ser levadas ao leitor que lerão os seus sentidos, como quem interpreta quadros enigmáticos. E se as imagens não aparecem, se estão invisíveis na brancura da tela, então mais enigmática 
essa linguagem torna-se.

O silêncio da tela alva foi materializado pelo pintor russo Malevitch em seu "Branco sobre branco"18. Com tom de humor e ironia Millôr Fernandes, que fez a capa e as ilustrações do retrato manoelino, certa vez, fez uma exposição de quadros todos brancos, talvez por isso esse artista escolheu o branco para pano de fundo de um livro de um poeta que explora os muitos sentidos dos silêncios.

No texto "Bing", de Beckett, a palavra white (branco) aparece em cinqüenta e nove das sua setenta frases e em Worstward ho é grande a repetição de termos como white (branco), blank (espaço em branco), blur (borrar), fade (apagar) e outros.

O branco, em Barros, às vezes, associa-se ao ágrafo:

Agora só espero a despalavra: a palavra nascida para o canto - desde os pássaros. A palavra sem pronúncia, ágrafa./ Quero o som que ainda não deu liga./ Quero o som gotejante das violas de cocho (RAQC -53).

Esse poema inspirou Millôr para fazer uma iluminura.

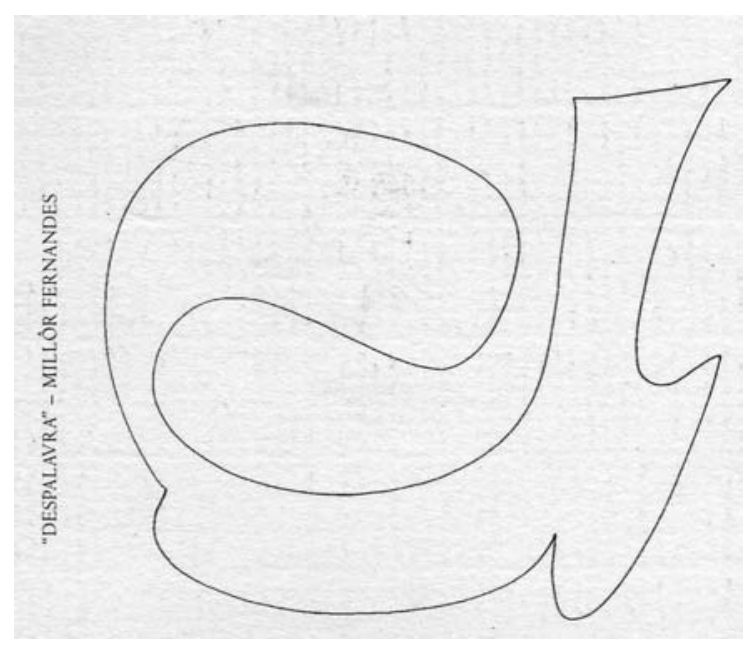

O desenho lembra a letra "d", de despalavra, seu título, e o caramujo. Esse animal, se produz ruídos, são inaudíveis para nós, o que reforça o tom silencial dessa despalavra manoelina. Os cararamujos, de Tratado geral das grandezas do ínfimo, são ressaltados pelo seu mutismo, ou melhor, pelos seus mutismos, já que se tornam cumulativos e cíclicos como o desenho da espiral no seu ${ }_{18}$ Agradeço a Elena Vássina a indicação dessa obra. 
corpo: Dentro dos caramujos -/ há silêncios/ remontados. (TGGI - 57).

É possível comparar a despalavra manoelina com a unword, de Beckett; o autor irlandês, em uma missiva a seu amigo Axel Kaun, afirma que a função do escritor moderno é a de perfurar a superfície dura da palavra para que o seu silêncio interior seja entrevisto pelo leitor. Assim, é proposta a literatura da não palavra (Literature of the unword):

Como não podemos eliminar a linguagem de uma vez por todas, devemos pelo menos não deixar por fazer nada que possa contribuir para sua desgraça. Cavar nela um buraco atrás do outro, até que aquilo que está a espreita por trás - seja isto alguma coisa ou nada comece a atravessar; não consigo imaginar um objetivo mais elevado para um escritor hoje.[...]. Há alguma razão pela qual a terrível e arbitrária materialidade da superfície da palavra não seria capaz de ser dissolvida, como pode, por exemplo, a superfície do som, rasgada pelas enormes pausas, da Sétima Sinfonia de Beethoven, de forma que, por páginas a fio, nós não podemos perceber nada a não ser um caminho de sons suspensos nas alturas vertiginosas, ligando insondáveis abismos de silêncio?Uma resposta faz-se necessária. [...]. Sei que há pessoas, pessoas sensatas $e$ inteligentes, para quem não faz falta o silêncio. Não posso senão concluir que são orelhas de pau. [...]. A caminho desta literatura da não palavra, para mim tão desejável, alguma forma da ironia nominalista poderia ser um estágio necessário. Mas não é suficiente que o jogo perca um pouco de sua sacrossanta seriedade. [Beckett, 2001, p. 169-170].

A noção de crise da palavra fica patente em ambos os casos, já que unword/despalavra se aproximam da linguagem da música, pois para Beckett avizinha-se da Sétima Sinfonia de Bethoven e para Barros da sonoridade das violas de cocho. Mas as diferenças entre as propostas e os estilos dos dois autores se percebem também. A despalavra de Beckett está associada à cultura erudita e a de Barros, apesar de ter também apelos a ela, possui sua pujança na cultura popular. No mesmo poema manoelino, aparece uma nota de rodadé explicando o que são as violas de cocho:

Estão registrados nas anotações antropológicas do mestre Roquete-Pinto os sons gotejantes da viola de cocho. A expressão é conhecida entre os índios guatós da beira do Cracará. A viola de 
cocho é levianinha e só tem quatro cordas feitas de tripa de bugio. É com ela que se acompanha o cururu, dança de origem indígena, disseminada entre os ribeirinhos do Cuiabá e do rio Paraguaio. (RAQC -53).

O mutismo, revelado na despalavra/ unword, de ambos os autores muitas vezes aponta para o óbito. Em “ $\mathrm{D}$ ' un ouvrage abandonné”, de Beckett, lê-se: Não há sol, a mesma luz cinza, silêncio de morte, nada se mexe.

Em Retrato do artista quando coisa, o sujeito poético enuncia: Me achei como aqueles des-heróis de Callais que Rodin esculpiu: nus de seus orgulhos e de suas esperanças. Só de camisolões e de cordas no pescoço. Pesados de silêncio e da tarefa de morrer. (Morrer é uma coisa indestrutível.) (RAQC - 65).

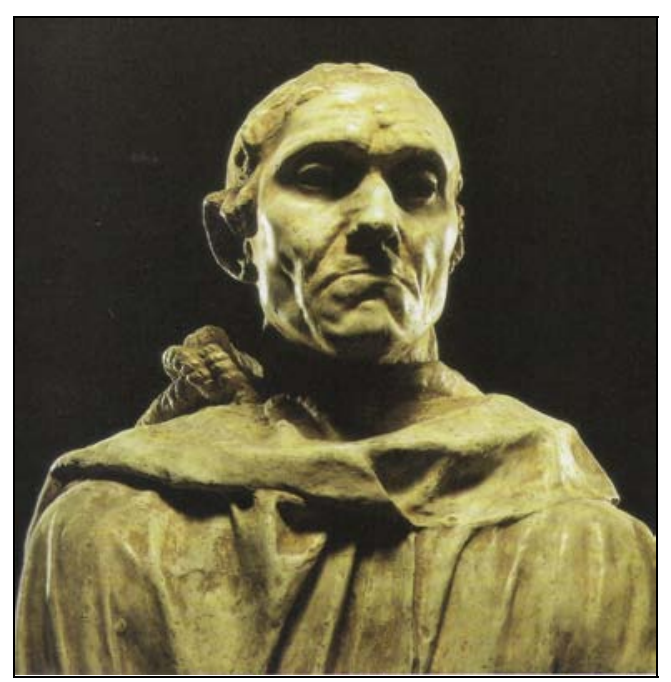

Detalhe de "Os burgueses de Callais", de Rodin

No detalhe acima, o mutismo se intensifica na boca fortemente cerrada de um dos homens pesados de silêncio.

As dimensões materiais do silêncio são exploradas por Barros, nesse Retrato do artista quando coisa, interessado na matéria de poesia. Beckett por outro lado, muito explorou uma poética da fantasmagoria, da desmaterialidade.

A imagem shakesperiana do pai morto que vem falar com o filho vivo tem grande repercussão na obra beckettiana. O branco, muitas vezes, nesses textos servem como metáfora para essa dimensão fantasmal.

O enunciador da nouvelle "O calmante", de Beckett é um morto e nesse 
escrito o silêncio da incomunicabilidade está fortemente presente. Em "Como é", lê-se: silêncio cada vez mais e mais longos e longos silêncios vastos tratos de tempo nós em falta cada vez mais ele de respostas eu de perguntas. (Beckett, 2003, p. 85).

A mudez que nega uma interlocução está também em "O expulso": Eu não lia jornais e também não me lembro de ter conversado com quem quer que seja, durante esses anos, a não ser talvez três ou quatro vezes por questão de comida. [Beckett, 2006, p.16].

Nessa novela, surge também o silêncio da escuta: o protagonista, que não tem nome, depois de se movimentar pela cidade com um cocheiro, é convidado por ele para dormir em sua casa. O convite é aceito e provisioriamente há um teto para o errante, que vai dormir na cocheira. Lá entrega-se ao mutismo audiente:

Não me lembro o que fazia o cavalo esse tempo todo. Deitado no escuro eu ouvia o barulho que ele fazia bebendo, é muito especial, as bruscas carreiras dos ratos e acima de mim as vozes abafadas do cocheiro e de sua mulher me criticando . [Beckett, 2006, p. 22].

Olhar não é ato ruidoso, portanto como saber, no escuro, que se está sendo olhado? Em "O expulso", o protagonista, depois de entrar no coche para dormir, percebe que é alvo do mirar de um cavalo, por causa de seu bafo quente: Várias vezes durante a noite senti o cavalo me olhando pela janela, e o bafo quente de suas ventas. O cavalo me seguia com os olhos. Então não dormem nunca, os cavalos? [Beckett, 2006, p. 23].

Em "O fim", o narrador, uma noite, dorme ao relento, perto de um bebedouro de cavalos:

Eu ouvia as ferraduras e o tinido do arreio. Depois o silêncio. Era o cavalo que me olhava. Depois o barulho de cascalhos arrastados na lama que fazem os cavalos quando bebem. Depois de novo o silêncio. Era o cavalo de novo me olhando. Depois de novo os cascalhos. Depois de novo o silêncio. [Beckett, 2006, p. 58].

Em muitos textos beckettianos, aparece uma antipatia dos personagens por animais. Em Molloy, por exemplo, Moran afirma: Há homens e há coisas, pro inferno, os animais. Isso aponta para uma diferença entre Beckett e 
Barros: enquanto a empatia dos seres manoelinos se dá intensamente com os bichos e outros elementos da natureza, no caso dos entes beckettianos ela ocorre com relação a seres inanimados, principalmente com bicicletas, como se nota no conto "Fingal", do livro More pricks than kicks:

Eles foram para onde um bicicleta estava [...]. Belacqual que não podia resistir a uma bicicleta, pensou: que extraordinário lugar para se percorrer. ${ }^{19}$

O crítico Menzies percebe que a bicicleta na narrativa beckettiana aparece como a viabilização da fuga dos personagens diante de sua falta de liberdade. Portanto, a bicicleta traz toda a vibração de uma possível viagem. [Menzies, 1980, p. 97].

O olhar que namora coisas percorre o alvo de seus desejos. A volúpia é pelos olhos, como no conto beckettiano "Ding dong": Sentado em sua embriagada toca, [...], ele parou para ver seus acessórios com prazer, as garrafas, [...], os banquinhos, o balcão, os poderosos parafusos, os cascos [...] tudo isso compunha um espetáculo com o qual Belacqua costumava se deliciar. [Beckett, p. 42].

Muitos retratos do artista quando coisa são possíveis. Beckett e Barros fazem os seus: em um, vêem-se bicicletas, em outro, caramujos, plenos de silêncios remontados, que parecem estar representados, neste desenho de Millôr.

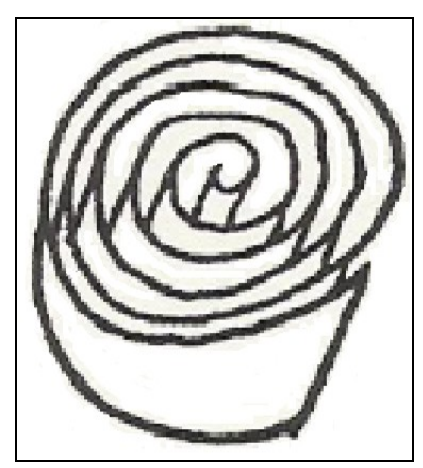

${ }^{19}$ Beckett, Samuel. "Fingal” in: More pricks than kicks, p. 27. A tradução é minha. 
Mariarosaria Fabris observa que essa imagem remete a um papiro que vai se desenrolando, a um palimpsexto, à infinitude da escrita, a um eterno recomeço ${ }^{20}$. Portanto, essa possível espiral, que está na última página de Retrato do artista quando coisa, antes da palavra "Fim", pode ser interpretada como uma referência à inacababilidade, negando o sentido de finitude do termo que surge abaixo dela.

A maior riqueza do homem é a sua incompletude, afirma o sujeito poético de Retrato... e em Matéria de poesia, o sujeito poético enuncia: A gente é que nem rascunho de pássaro/ Não acabaram de fazer... Esses dois últimos versos são as palavras que aparecem no infindo fim do filme "Caramujo-flor", de Joel Pizzini, adaptação dos poemas de Barros para o cinema.

Isso aproxima a obra de Barros da de Beckett, pois a inacababilidade da obra beckettiana demanda releituras. A extensa fortuna crítica beckettiana, principalmente por causa de obras como Esperando Godot, comprova isso.

Uma dessas releituras aproximou a mencionada e célebre peça do autor irlandês ao filme "A estrada", de Federico Fellini. Essa comparação foi feita por Katia Peixoto dos Santos, em uma seção da sua dissertação intitulada "A presença do espetáculo circense, mambembe e do teatro de variedades no contexto fílmico de Federico Fellini”, defendido em 2001, junto à ECA - USP.

Katia afirma: Contemporâneos, Fellini e Beckett, realizam respectivamente em La strada e Esperando Godot um relato da condição humana do período pós-guerra, tendo como personagens principais figuras caricatas marcantes. [Santos, 2001, p. 32].

O uso da metáfora aproxima ambos os artistas e esse recurso da linguagem é afeito ao silêncio já que nega afirmações categóricas e pauta-se, muitas vezes, na cifra, nas entrelinhas. Sobre esse recurso na obra beckettiana, a estudiosa afirma: Em esperando Godot, Beckett encontra na metáfora sua maior forma de expressão. [...]. O simbolismo é evidenciado nos chapéus-coco - representando o pensamento, a razão e nas botas - a emoção, o sentimento de busca e o anseio de prováveis soluções. Quando as personagens estão no ápice do conflito Vladimir procura soluções no chapéu e Estrago nas botas. Sentimento e razão brigando entre si. Estragon e Vladimir

20 Mariarosaria fez essas observações na defesa de minha tese, no dia 28 de agosto de 2007. 
vivem numa perpétua oscilação entre o máximo e o mínimo, num paradoxo perene, arrisco dizer que eles são a própria reflexão existencial do ser. [Santos, 2001, p. 36-37].

A respeito das personagens fellinianas, Katia afirma: A relação de Gelsomina [dominada]/ Zampanô [dominador], metaforicamente retrata as relações de poder existentes na sociedade, e a condição humana do período do pós-guerra na Itália.

Fellini é mencionado em um poema de Retrato do artista quando coisa, que será analisado a seguir. 


\section{TÁCITO ÊXTASE}

Dominara da estrada ao pó das trilhas;

[...]

Umedecido dos óleos da noite, pauis

-Está aqui e está ali.

Reflexo metálico

$D^{\prime}$ um êxtase entregue aos dons da noite

["O incerto", de Fausto Marthe]

Um dia me chamaram primitivo:

Eu tive um êxtase.

Igual a quando chamaram Fellini de palhaço:

E Fellini teve um êxtase.

Ao pensar nos preconceituosos e desinformados, certa vez, Lévi-Strauss afirmou que primitivo é aquele que chama o outro de primitivo, já que os sentidos de grosseiro, atrasado e congêneres não servem para os homens das sociedades tribais, com seu refinamento e suas complexidades culturais.

Talvez por isso, Meletínski usa aspas nessa palavra: o homem "primitivo" ainda não separava nitidamente a si mesmo do mundo natural circundante $e$ transferia para os objetos naturais suas próprias características.

No caso dos índios, fica patente o deslimite, para usar um termo de Barros, entre natureza e homem, quando usam em seu corpo penas de pássaros e tintas extraídas dos vegetais. Essa estética indígena talvez tenha atraído Artaud, quando buscou o convívio com os Tarahumaras, índios mexicanos. Ele estava muito interessado em aproximar-se dos seus silêncios, como aponta Jucimara Tarricone.

Também à procura do mutismo primevo, William Samarin se dirigiu à Africa, em 1965, para estudar a tribo dos Gbeyas; ele percebeu que eles se calavam nas refeições e nas visitas aos doentes, oferecendo o mutismo como presente, tão eficiente quanto erva curadora. [Bacalarski, 1991, p. 40-42].

Keith Basso estudou uma tribo de Apaches, numa reserva no Arizona. Notou que a inarticulabilidade tinha, socialmente, uma conotação positiva, pois ela impedia o confronto diante de uma pessoa enraivecida, mostrava respeito diante de uma família enlutada e aproximava um casal em fase inicial de 
namoro [Basso, 1970, p. 213-230].

Talvez por tudo isso, o sujeito poético de Retrato... teve um êxtase ao ser chamado de primitivo e esse termo, já era usado, com sentido positivo, por um autor admirado por Barros: Machado de Assis.

O Bruxo de Cosme Velho se serve do vocábulo primitivo para referir-se ao estilo e ao tom do discurso de José de Alencar em Iracema:

Tudo ali nos parece primitivo; a ingenuidade dos sentimentos, o pitoresco da linguagem, tudo, até a parte narrativa do livro, que nem parece obra de um poeta moderno, mas uma história de bardo indígena, contada aos irmãos, à porta da cabana, aos últimos raios do sol que se entristece. A conclusão a tirar daqui é que o autor houve-se nisto com uma ciência, para as quais todos os louvores são poucos. (Assis, apud: Alencar, 1955, p. 17).

Mário de Andrade, como Machado, oferece positividade ao termo primitivo: Somos na realidade os primitivos duma nova era, escreve ele, no "Prefácio interessantíssimo" da Paulicéia desvairada.

No universo primitivo, não há hierarquia: elementos do reino mineral, vegetal, animal e hominal estão no mesmo patamar de importância. Por isso, em Retrato do artista quando coisa, ocorre uma comunhão neste poema:

A menina apareceu grávida de um gavião./ Veio falou para a mãe: O gavião me desmoçou./ A mãe disse: Você vai parir uma árvore para/ a gente comer goiaba nela./ E comeram goiaba./ Naquele tempo de dantes não havia limites para ser./ Se a gente falasse a partir de um córrego/ a gente pegava murmúrios./ Não havia comportamento de estar. Urubus conversavam sobre auroras. Pessoas viravam árvores./ Pedras viravam rouxinóis. Depois veio a ordem das coisas e as pedras/ têm que rolar seu destino de pedra para o resto dos tempos./ Só as palavras não foram castigadas com/ a ordem natural das coisas./ As palavras continuam com os seus deslimites.

Quero ser um recém-nascido, para ser quase um primitivo, afirmou Paul Klee, que, ao final da vida, perseguiu o primevo dos hieróglifos e das imagens inscritas nas cavernas. A simplicidade desses universos representacionais é buscada em "Parque perto de Lu(cerna)". 


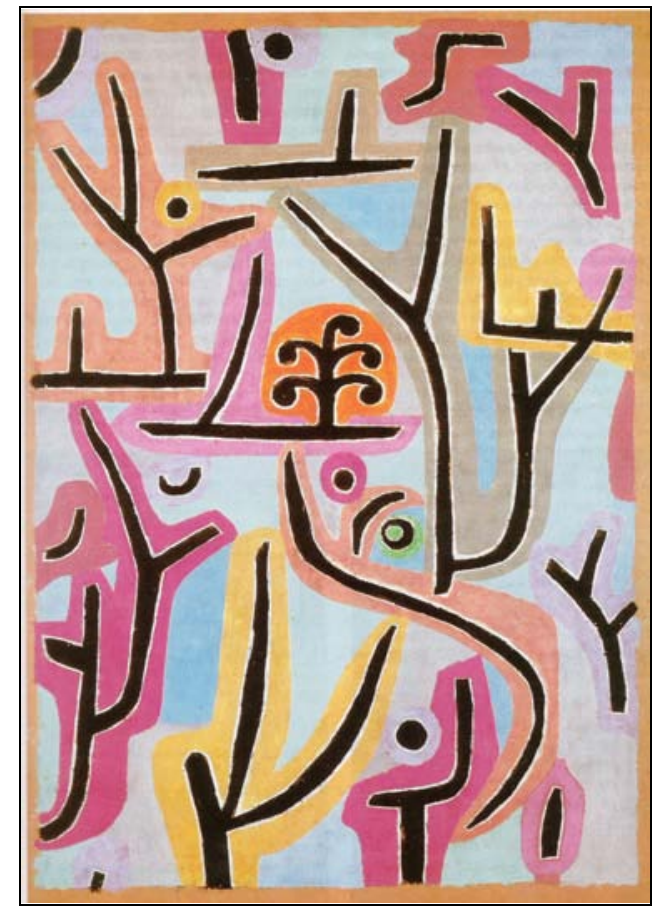

“Parque perto de Lu(cerna)”, de Paul Klee.

Nesse quadro, pode-se ver a cor do êxtase [GA - 285], para usar uma expressão do sujeito poético de $O$ guardador de águas.

O êxtase no poema em análise, já havia aparecido no livro manoelino Concerto a céu aberto para solos de ave, de 1991:

Fica evidente, pois, que é inenarrável o êxtase tido a partir da visão do cisco. Apenas os olhos atuam, a boca não.

Barros retoma os pontinhos de Machado de Assis, no seu Memórias póstumas de Brás Cubas, mostrados no primeiro capítulo, mas há uma diferença importante: cabe nos misteriosos e silentes pontinhos do poema manoelino um sentido místico, que Leo Sptizer notou em três célebres poetas. O crítico, em Três poemas sobre o êxtase, observa que o termo êxtase vem do 
grego ekstasis: sair, partir e analisa "O êxtase", de John Donne, "Em uma noite escura", de San Juan de la Cruz e uma cena do terceiro ato de "Tristão e Isolda", de Richard Wagner.

Antes de interpretar Wagner, Spitzer afirma que está consciente que pode haver críticas por sua escolha de poema que se associa à música - arte que por definição transcende as palavras. [Spitzer, 2003, p. 83]. Talvez por esse motivo ou um outro misterioso, o texto de Spitzer sobre o poema wagneriano é bem mais curto do que os outros dois.

O êxtase musical dispensa tantas palavras, mas Sptizer não as mede para tratar do êxtase em si. No poema de Donne, um casal sente prazer a partir do momento em que suas almas se desprendem dos seus corpos, não via morte, mas por intermédio de uma sessão de gozo, encontrado em atmosferas espirituais. Depois, voltam à morada carnal e o poema se encerra. O crítico mostra que, nesse caso, o prazer a dois é destituído do corpo, talvez pela influência do protestantismo na obra de Donne.

Já no catolicismo de San Juan de la Cruz, e seu poema "Em uma noite escura", o prazer espiritual inclui o corpo, talvez porque Jesus se fez carne, na liturgia da igreja romana, na qual a materialidade crística é constantemente valorizada na idéia da transubstanciação. O sujeito poético tem êxtase não com um outro ser terreno, como no caso do poema de Donne, mas sim com Deus e chega à morte, o que não ocorre no contexto do autor inglês.

O êxtase também se associa à morte em um trecho do terceiro ato de Tristão e Isolda, de Richard Wagner. Isolda, moribunda, sente intenso prazer ao entrar em contato com o corpo do seu amado já morto: sente a luz que emana de seu olho ainda aberto [...], o perfume que seus lábios ainda exalam [...], a música que ressoa de seu peito ainda palpitante [...]. [Spitzer, 2003, p. 85].

Visão, olfato e audição se fundem no momento extático de Isolda, que tem um caráter erótico, diferentemente dos contextos dos outros poemas estudados por Spitzer. O crítico afirma que Wagner era freudiano antes de Freud e que há nessa sua poesia um panteísmo que faz com que, no ato de prazer, haja tal libertação da consciência e da individualidade [Spitzer, 2003, p. 
90] que ocorre uma proximação do nirvana.

O êxtase do poema de Barros relaciona-se mais a essa terceira modalidade, porque ser "primitivo" é entregar-se à força e aos encantos materializados da natureza, já que há algo de panteísta na situação.

Muitos êxtases foram experimentados por espectadores diante dos filmes de Federico Fellini, que é citado no poema em análise: Um dia me chamaram primitivo:/ Eu tive um êxtase./ Igual a quando chamaram Fellini de palhaço:/ E Fellini teve um êxtase.

Ser chamado de palhaço, ao invés de ofender, tinha o tom do elogio para Fellini, porque a força dos seus filmes está, também, no tom humorístico, mesmo que não seja de seres circenses, como Cabíria (de "Noites de Cabíria"), Gelsomina (de "A estrada da vida") e outros tantos que fazem rir e mostram muita dignidade.

Os palhaços foram tema de um documentário do diretor, em 1970, "I clowns", que tem vários momentos hilários, inclusive nas situações mais tristes, como a da morte. Um palhaço falece e todos os outros tentam colocá-lo no caixão para, posteriormente, enterrá-lo, o que garante a confusão, em meio ao choro dos presentes e ao escândalo da inconsolável viúva (um homem de nariz vermelho com um vestido negro, exibindo fartos seios e amplas nádegas). O tom bufo está na própria equipe de filmagem com uma secretária, um técnico de som e um cinegrafista extremamente confusos e desastrados. 


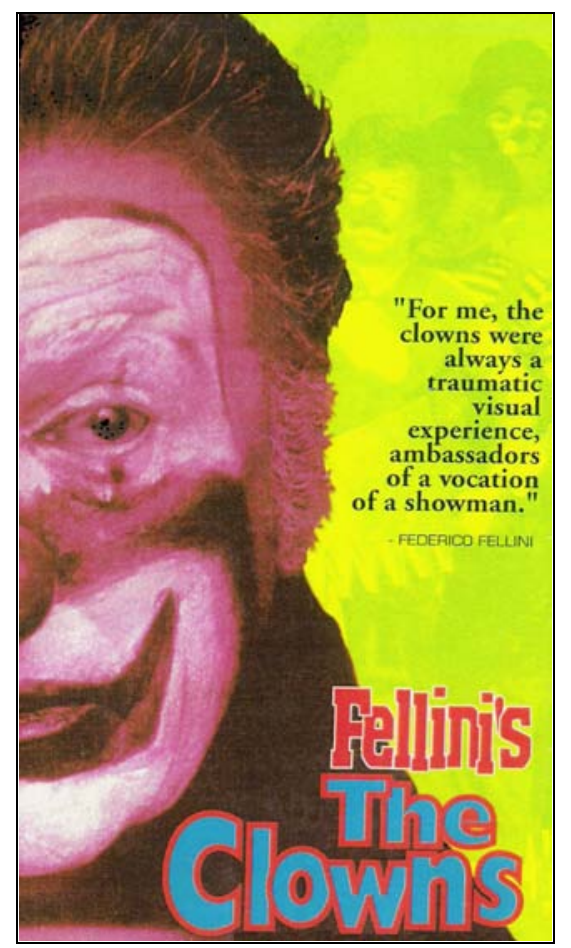

Outra seqüência que se destaca na película é quando Fellini é entrevistado por uma mulher que lhe faz uma pergunta sobre seus filmes. A resposta é o silêncio, porque, do picadeiro, é lançado um balde, por um palhaço, que cobre sua cabeça.

O circo inspirou os roteiros de Fellini, como ele próprio afirma: Eu me sinto um pouco embaraçado de falar ainda do circo, depois de ter feito isso em todos os meus filmes. [Fellini, 1986, p. 26].

Mariarosaria mostra que o final pujante de $81 / 2$ é siderado por um ciranda circense (Fabris, 2004, p. 6). Em "Ensaio de orquestra", dois músicos trocam pequenos e vários tapas, como é típico dos palhaços de um picadeiro.

É por esse e outros motivos que ser chamado de palhaço é elogio para um diretor tão sensível à condição humana, tanto em situações cômicas, como trágicas, porque os palhaços fellinianos também fazem chorar, como Cabíria, Gelsomina e outros.

Além disso, o menino Fellini entregou-se às lágrimas, quando levado pela primeira vez ao circo: sentiu medo daquelas figuras com rosto pesadamente pintado e expressões bizarras. Mas, associado ao medo, havia também um chamado como aponta o diretor em uma entrevista: Quando chegou a hora do espetáculo e explodiram diante de mim, que estava sentado nos joelhos de 
meu pai, as cornetas, as luzes, os aplausos, o rufar de tambores, a gritaria estridente dos palhaços, sua irracionalidade desengonçada, bufa, era como se eu fosse desejado, como se me esperassem. Parecia que me reconheciam, como os marionetes de Come-Fogo, que do palco viram Pinóquio no fundo da tenda e o saudaram como um deles, chamando-o pelo nome, abraçando-o e dançando juntos a noite toda. De fato voltava todo dia ao circo, no tempo em que permaneceu armado perto de casa, assistindo aos seus ensaios $e$ espetáculos. [Fellini, 1986, p. 26].

Apesar do universo ruidoso do circo, Fellini percebeu nele algo de silencioso, como uma misteriosa e quieta anunciação: Uma espécie de reverberação exaltante, profética, antecipadora é o que recordo ter experimentado na primeira vez que pus os pés no ventre palpitante, úmido, silencioso, da lona do circo. [Fellini, 1986, p. 26].

Barros, também, associa a imagem do circo a um universo silencioso, o da pré-palavra:

\section{ASCENSÃO}

Depois que iniciei minha ascensão para a infância,/ Foi que vi como o adulto é sensato!/ Pois como não tomar banho nu no rio entre pássaros?/ Como não furar lona de circo para ver os palhaços?/Como não ascender ainda mais até na ausência da voz? (Ausência da voz é infantia, com $t$, em latim.)/ Pois como não ascender até a ausência da voz - Lá onde a gente pode ver o próprio feto do verbo - ainda sem movimento/ Aonde a gente pode enxergar o feto dos nomes - / ainda sem penugens./ Por que não voltar a apalpar as primeiras formas da/ pedra. A escutar/ Os primeiros pios dos pássaros. A ver/ As primeiras cores do amanhecer./ Como não voltar para onde a invenção está virgem?/ Por que não ascender de volta para o tartamudo! (TGGI - 41).

Retomando o depoimento de Fellini, o diretor mostra o seu apreço pelo silêncio da escuta: Estava em minha casa naquele vazio encantado, a serragem úmida, os golpes de martelo, baques surdos que vinham de todas as partes, o relincho de cavalos... Era o circo de Pierino, que descrevi também em "I Clowns". [Fellini, 1986, p. 26].

Mas o mutismo audiente, no contexto felliniano, volta-se não só para a 
alteridade como também para a interioridade: Tenho 64 anos. Repito isso a mim mesmo como a convencer-me, e depois permaneço na escuta, o ouvido mergulhado em meu interior, para sentir que coisa mudou, se algo enferrujou, se há alguma falha, em suma, o que sente e o que pensa uma pessoa de 64 anos. [Fellini, 1986, p. 1].

Um outro silêncio usado por Fellini é o da arte visual em si, substituindo palavras por cores, o que se pode notar em "Amarcord".
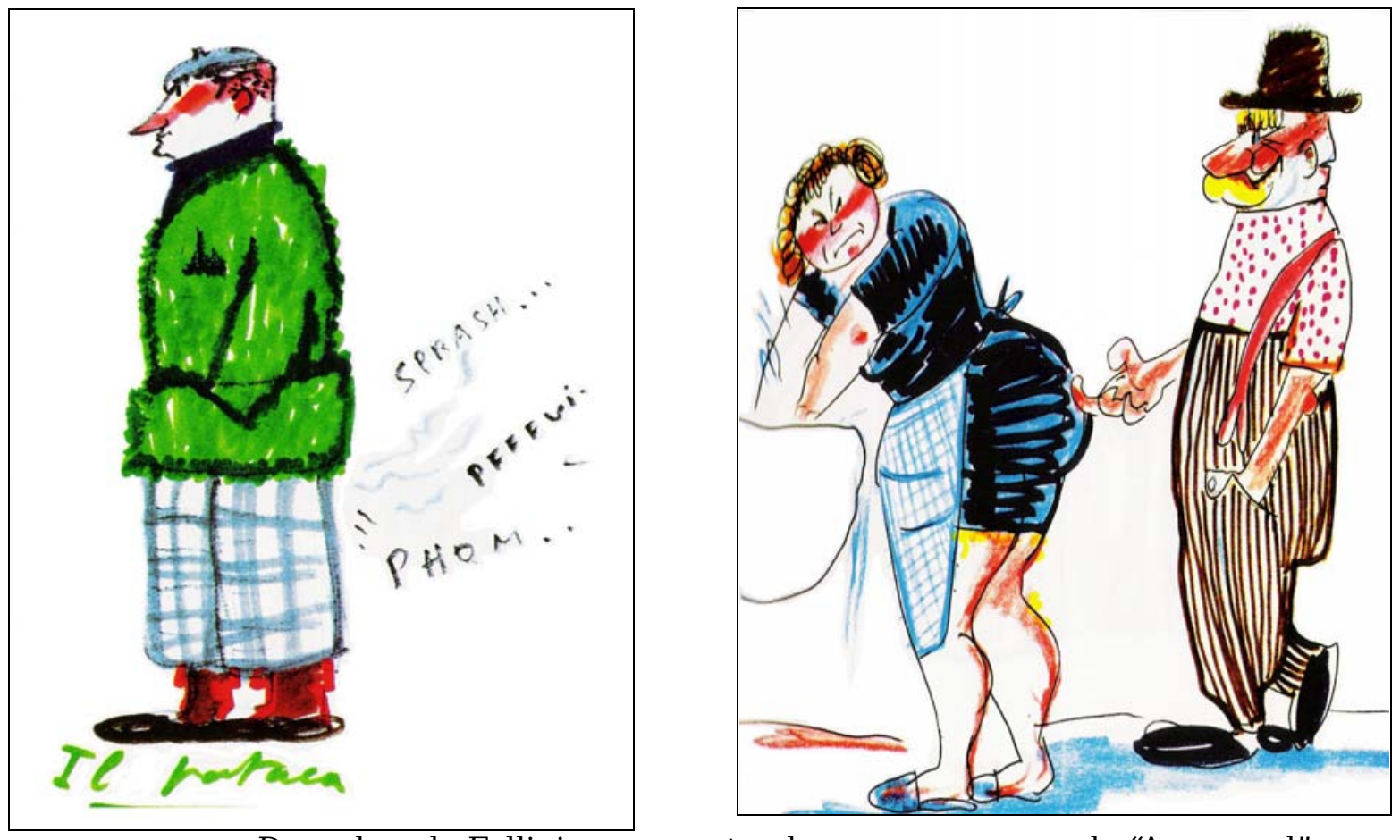

Desenhos de Fellini, representando os personagens de "Amarcord".

Nesses dois desenhos fellinianos para "Amarcord", os personagens masculinos, pelo colorido e pela extravagância das roupas, bem como pelos seus narizes vermelhos, estão próximos aos palhaços.

O humor em "Amarcord" muitas vezes atinge um tom clownesco. Segundo Luis, se em 8 1/2 preponderava o grave monólogo interior, já em "Amarcord", de 1973, o que impera é o dialogismo de uma coletividade, entremeado de humor.

Luis Renato Martins, no segundo capítulo de seu livro Conflito $e$ interpretação em Fellini, aponta uma cena emblemática no sublinhar dessa idéia de coletividade: a masturbação na garagem, [...], ato normalmente solitário, torna-se atividade de grupo e é submetida a um enfoque 
generalizante, que enquadra os gestos juvenis, como séries ou repetições, numa cena cômica que evoca até o automatismo de Chaplin, em Tempos modernos. [Martins, 1993, p.64].

A idéia de uma coletividade de pouca idade com preocupações de ordem sexual está presente também em Retrato do artista quando coisa:

A gente se negava corromper-se aos bons/ costumes./ A gente examinava a racha dura das lagartixas/ Só para brincar de ciência./ A gente grosava a peça dos morcegos com o/ lado cego das facas/ Só para vê-los chiar com mais entusiamo./ Fazíamos meninagem com as priminhas àl sombra das bananeiras, debaixo dos laranjais/ Só de homenagem ao nosso Casimiro de Abreu./ [...]. [RAQC - 39].

A apreciação de Chaplin é uma coincidência entre ambos os artistas e Ismail Xavier, na orelha do livro de Luis Renato Martin, afirma que o diretor italiano e o norte-americano conseguem um fato raro: unidade entre crítica e público: [Fellini é] clown que repetiu a façanha de Chaplin ao fazer comungar crítica e público, arte e mercadoria. [Xavier, texto-orelha em Martins, 1993].

Talvez essa seja uma diferença que, ao menos transitoriamente, pode ser vista entre Barros e Fellini: durante muitos anos, o poeta não era consenso entre crítica e público, ou seja, enquanto era saudado como um dos melhores poetas por Houaiss e outros, era completamente ignorado pelo grande público, o que mudou recentemente.

A filha de Chaplin aparece no documentário felliniano "I clowns" e, nos primeiros minutos de "E la nave va", que são silenciosos e alvinegros, aparece um personagem, que é um humorista, com gestos e movimentos que lembram os do cineasta norte-americano.

O humor, seja dos gibis, mencionado por Mariarosaria, seja da caricatura, conforme Luis, seja de inspiração chapliniana, para Luis e Ismail, é uma coincidência entre Barros e Fellini, o que fez, no caso do diretor italiano, com que ele tivesse um êxtase a partir da escuta ou da leitura de um substantivo com o qual se tentava classificá-lo: palhaço.

"Amarcord" pode ser considerado um auto-retrato palhaço do diretor, já que contém muitas cenas hilárias, principalmente na escola de Titta, na qual 
ele e seus colegas arrancam risos de toda a sala de aula com suas piadas e ridicularização do autoritarismo de muitos dos professores, cuja palavra mais repetida é "Silêncio!".

No Brasil, o autoritarismo escolar se serviu de livros didáticos que continham frases como "Ivo viu a uva". Essa frase e aqueles que serviam dela para tentar padronizar os pensamentos das pessoas são criticados neste poema de Retrato...:

[...]. Não aguento ser apenas/ um sujeito que abre portas, que puxa válvulas, que olha o relógio, que compra pão às 6 da tarde, que vai lá fora, que aponta lápis, que vê a uva etc. etc. [...]. [RAQC - 49]

A ridicularização atinge também outro alvo em "Amarcord": o fascismo. $\mathrm{O}$ ardor quase irracional dos fascistas é mostrado na película, gerando lágrimas e corridas apaixonadas para a saudação de um painel com o rosto de Mussolini, que, na fantasia de Ciccio, faz a função de um padre no seu imaginado casamento com Aldina. Eles são saudados por jovens que levantam bambolês e armas.

Também Barros ridicularizou o governo militar, em Gramática expositiva do chão, de 1966, e, principalmente, em Matéria de poesia, de 1970, já que o desgaste e o descrédito da palavra dos políticos autoritários são criticados nesta passagem: Estadistas gastavam nos coretos frases furadas,/ já com vareja no ânus..[MP].

Uma diferença entre "Amarcord" e Retrato do artista quando coisa é com relação ao silêncio: no filme ele está quase ausente, uma vez que se baseia no palavroso discurso dos personagens ou narradores que corre paralelamente às imagens. Já em Retrato..., o mutismo é mais freqüente.

Um bicho gera mutismos, em uma das raras cenas silenciosas de "Amarcord": um pavão pousa no gelo e abre sua colorida calda, calando todos os personagens, que extáticos miram-no. Uma outra situação de inarticulabilidade: Titta, depois do enterro de Miranda, sua mãe, ronda, calado, os cômodos da casa e vê o pai mudo na cozinha, catando feijão.

Morte e mortos estão presentes em "Julieta dos espíritos", como se pode notar já no título. O filme começa com a retratada de costas. 


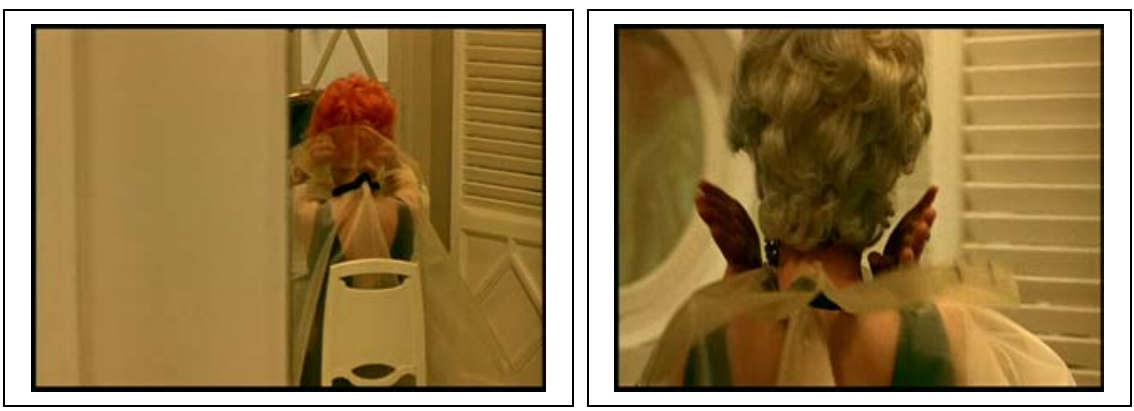

Fotogramas das cenas iniciais de "Julieta dos espíritos".

"Julieta...", de 1965, é o primeiro longa-metragem a cores do diretor italiano. Em 1962, Fellini já havia realizado seu primeiro curta-metragem colorido: "As tentações do Dr. Antonio", que juntamente com outros três filmes de diretores italianos construíram a policromia do filme "Boccaccio '70" .

"Julieta dos espíritos" é muito mais colorido que "As tentações do Dr. Antônio". O vermelho, por exemplo, aparece recorrentemente no filme; ele está em várias roupas da protagonista, no seu lenço usado na cabeça.

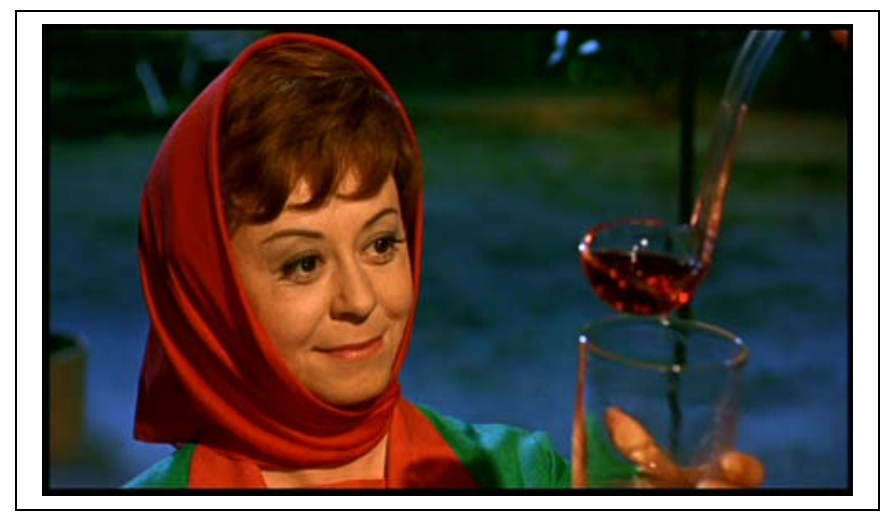

Um dia Julieta consulta um guru indiano, sendo recebida numa compartimento com paredes rubras. Ele afirma que ela terá naquele mesmo dia uma surpresa e que a sangria mata as sedes, até as jamais confessadas.

Julieta chega a casa, com um lenço vermelho na cabeça, abre o portão e tem medo ao ver um desconhecido que se aproxima: José. A imagem da chapeuzinho vermelho parece que é evocada nessa cena, já que o espanhol está numa "floresta" metaforizada no jardim da casa da protagonista e oferece um grande "perigo" a ela: a possibilidade de tornar-se seu amante.

$\mathrm{Na}$ Espanha, José havia hospedado Giorgio, o esposo de Julieta, que 
pergunta ao espanhol: Onde encontraria a paz que temos aqui? O silêncio. Em seguida entram na casa e ao ficar só com Julieta o espanhol recita esses versos de Garcia Lorca: Ninguém entendia o perfume de magnólia de seu ventre/ Ninguém sabia do martírio de um colibri de amor.

O vermelho como metáfora da paixão é plausível no filme, principalmente quando depois da imitar um toureiro, José dança lentamente com Julieta, segurando seu lenço vermelho.

José é um interessado na boa pintura, pois Giorgio afirma: [José] Tem um palácio e belos quadros. Dois Goya! Goya ou Velázquez? José responde: Nem um, nem outro. Rivera.

Diego Rivera foi um pintor mexicano, que retratou os índios.

Ver índios é ação cara para Rivera e Barros. O poeta cuiabano, além de vê-los, põe-se a fazer silêncio para escutá-los:

As árvores velhas quase todas foram preparadas/ para o exílio das cigarras./ Salustiano, um índio guató, me ensinou. E me ensinou mais: Que as cigarras do exílio/ são os únicos seres que sabem de cor quando a noite está coberta de abandono. Acho que a gente deveria dar mais espaço para esse tipo de saber./ O saber que tem força de fontes. [RAQC $-63]$.

A força de fontes em Rivera está revelada no vermelho [índice cromático que representa os índigenas] e no marron [cor secundária na qual o vermelho está presente] no quadro "A libertação do peão". 


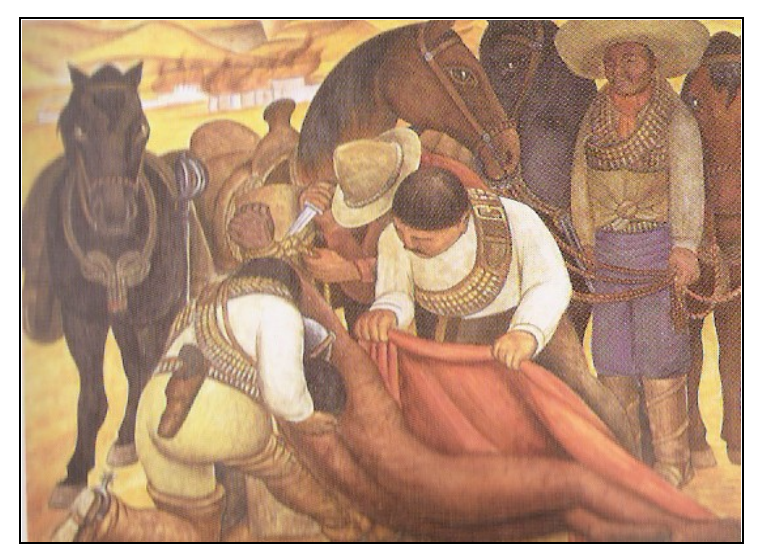

“A libertação do peão”, de Diego Rivera, de 1931

O vermelho em Retrato do artista quando coisa está associada à natureza, com a qual os índios mantêm intenso contato:

Na língua dos pássaros uma expressão tinge a
seguinte./ Se é vermelha tinge a outra de vermelho./
Se é alva tinge a outra dos lírios da manhã./ É língua
muito transitiva a dos pássaros./ Nâo carece de
conjunções nem de abotoaduras./ Se comunica por
encantamentos./ E por não ser contaminada de
contradições/ A linguagem dos pássaros/ Só produz
gorjeios. [RAQC - 37].

O branco, que também está nesse poema, aparece recorrentemente em "Julieta dos espíritos". Em várias situações, a protagonista veste roupas dessa cor, como em uma cena na praia, em que, ao adormecer, Julieta se vê diante de um homem que pede que ela puxe uma corda que vem do mar.

Esse trecho é bastante metafórico, pois, esse mesmo ator interpretará, posteriormente, o dono de uma agência de detetives, que fará o trabalho de filmar e fotografar seu marido bem como gravar suas conversas com a amante.

Assim, nesse sonho, Julieta vê antecipadamente o que vai ocorrer: aquele homem a ajudará a trazer à tona imagens e sons submersos. Nessa situação vindoura ela também estará de branco.

O branco, segundo a Física, contém todas as cores. Nada mais apropriado para essa policromática história.

Uma das seqüências mais coloridas do filme é a da festa da vizinha da protagonista, Suzy. Nela, uma cantora entoa um canto sem palavras, que silenciosamente comunica-se: todos ficam pensativos, distantes, calados, com a 
música.
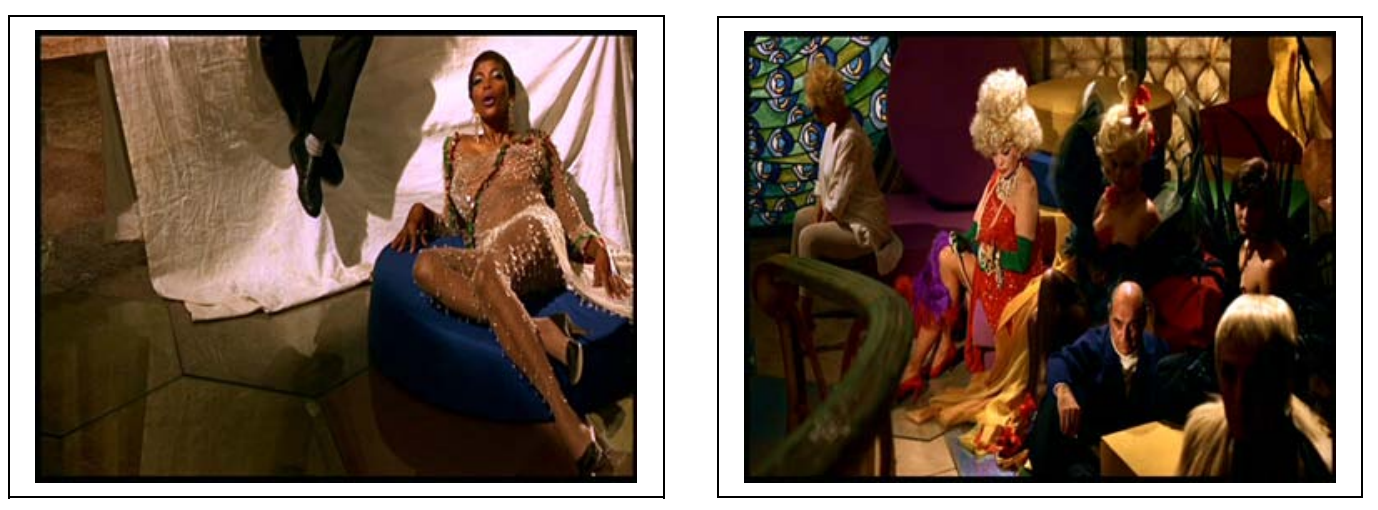

A festa na casa de Suzy

O silêncio ligado à música foi explorado por Fellini no filme "Ensaio de orquestra". Nele, um maestro afirma: Lembro a primeira vez que subi ao pódio. A maior impressão foi o silêncio enorme na minha frente. Dei o sinal para começar e vi com emoção que toda a orquestra estava ligada à minha batuta. Sua voz nascia da minha mão. Ela fazia a orquestra sair do silêncio e voltar ao silêncio. Essa voz subia como a onda do mar. ao levantar o braço que movia no ar como a asa de um pássaro. E, ao abaixá-la, a voz se se afastava até o silêncio.

Um músico da orquestra fala: $O$ trompete é um instrumento apaixonante, formidável! Sua capacidade musical é milagrosa. [...]. Com ele, pode-se expressar tudo o que se tem dentro: a alegria, a tristeza e o silêncio.

Um outro enuncia: $O$ oboé é um instrumento magnífico! O mais antigo. [...]. É um instrumento de elevação espiritual. Desenvolve poderes especiais em quem o toca. Uma visão capaz de perceber a cor do som. [...]. Uma experiência sobre-humana.

Em outro filme felliniano, "A voz da lua", um coveiro tem uma experiência sobre-humana, quando toca seu oboé: ele vê e ouve os mortos. O mesmo ocorre com a protagonista de "Julieta dos espíritos", sem se servir de algum instrumento musical. Em uma cena, ela afirma para suas amigas, que viu, quando pequena, o seu avô, depois de morto, no corredor da sua casa. Quando ainda estava vivo o avô de Julieta a levou ao circo, lá ele conheceu uma bailarina pela qual se apaixonou.

Em outra seqüência, quase ao final da película, a protagonista, que, segundo o místico Genius, é muito dotada, vê Laura, sua amiga de infância que 
se suicidou, jogando-se num rio, aos quinze anos. As palavras da morta são essas: Aqui tudo é cinza, tudo é silêncio.

Há vários outros silêncios em "Julieta dos espíritos", um deles é o da personagem Arlette, que mora na casa de Suzy. Durante todo o filme ela, que já havia tentado o suicídio por três vezes, permanece muda.

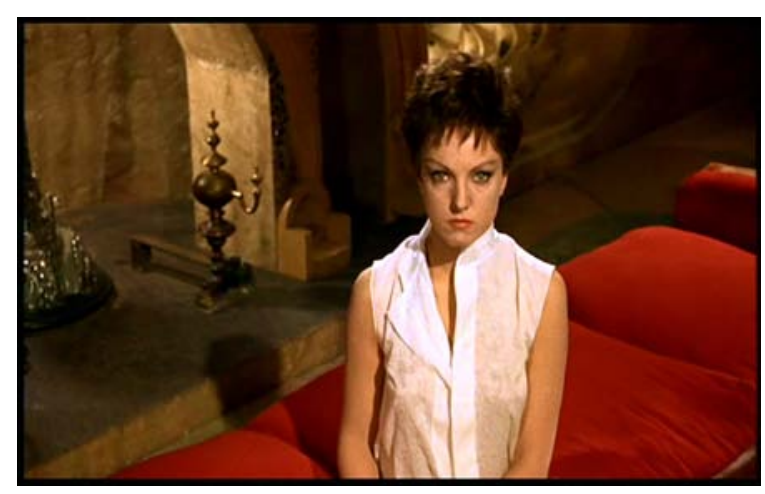

A quieta Arlette.

Ouve-se a mudez, em várias situações do filme, já que alguém liga várias vezes para a casa da protagonista e se cala. Esse silêncio até antes da descoberta da amante de Giorgio era entendido como um trote inofensivo, mas depois gera apreensões e crises em Julieta, inclusive porque em uma situação, a protagonista escuta de seu quarto uma conversa suspeita, ao telefone de seu marido: Mandei trocar o forro era vermelho, agora é preto com assentos cor de tabaco. Gostou?

Os mutismos estão presentes desde os primeiros filmes fellinianos. O silêncio bélico, por exemplo, mais especificamente o dos torturados que não denunciam seus parceiros, foi explorado em uma película na qual Federico contribuiu no roteiro: "Roma, cidade aberta", de Roberto Rosselini.

Manoel de Barros, em "A volta", do livro Poesias, mostra um homem que retorna de uma situação que não é explicitada no escrito, mas que gerou muitos ferimentos, inclusive físicos, ou seja, no silêncio do subtexto, parece que se está diante de uma cena do pós-guerra. Num trecho do mesmo poema, é usada a expressão "doce vida", que pode ser uma menção à película felliniana.

$\mathrm{Na}$ fase neo-realista, Fellini tratou do mutismo gerado pelas desigualdades sociais em seu curta-metragem "Agência matrimonial", que faz parte do filme "Amor na cidade", do qual participam também Michelangelo e 
outros.

Nessa história felliniana, um jornalista faz uma pesquisa sobre agências matrimoniais. Inventa que tem um amigo que sofre de licantropia que quer se casar, mesmo sendo perigoso. A empresa oferece seu serviço, apresentando ao rapaz uma moça. Quando ele pergunta a ela por que aceitou ter uma futura experiência que a colocaria em risco, a moça afirma que o motivo é que o casamento a tiraria da miséria e da fome.

Isso deixa o rapaz atônito e mudo. Sua narração final mostra a seguinte situação: Voltamos para casa em silêncio. Sentia que devia dizer alguma coisa não para me justificar, mas para ajudá-la. Gostaria de lhe dizer que tivesse mais confiança em si, que olhasse em volta que abrisse os olhos às infinitas possibilidades de encontros que a vida oferece a cada dia. Mas tudo isso me parecia retórico e era, sobretudo, inútil. As dificuldades imediatas, as angústias cotidianas a serem superadas, iriam continuar a ser, para ela, a única coisa importante e real. Não disse nada. Só quando nos deixamos lhe desejei sinceramente boa sorte.

Retomando os silêncios de "Julieta dos espíritos", há o das artes visuais, ou seja, aquele que substitui palavras por formas, como é o caso da escultura. Uma amiga da protagonista quer criar "A escultura de Deus quando coisa", pois afirma: Vamos desenvolver a dimensão física de Deus! Temia Deus. Ele me oprimia, assustava. E por quê? Eu o imaginava em forma abstrata. Mas não. Deus é o mais belo corpo que existe. Em minhas estátuas, Ele é físico, corpóreo, de forma perfeita, para que eu possa desejar até como amante.

Julieta vê a concretude, a coisa, mas também vê o diáfano, a imaterialidade, o que justifica o título do filme. A visão, nos seus mais diversos sentidos, parece fundamental na biografia de Federico Fellini. Talvez a intensa dedicação a ela tenha contribuído para que o diretor tenha sido chamado de visionário, classificação com a qual não concordava: Os críticos, quando falam de meu cinema, usam o termo visionário, mais em sentido literal do que figurado... não levam em conta o fato de que para mim, a luz é mais importante do que o argumento; a luz é fundamental para o cinema, é o estilo, o sentimento de um cineasta. Com a luz pode-se fazer tudo. [Fellini, apud: Fabris, 2004, p. 6]. 
Mariarosaria aponta que, para Milo Manara, cartunista e colaborador de Fellini, o termo visionário é realmente impróprio, e resolve substituí-lo por outro: Visionário me dá um pouco a idéia de alguém vagamente alucinado, que vê coisas onde elas não existem, vítima de miragens criadas por uma fantasia excessiva. É outro o termo que eu associo a Fellini: "transfiguração". Entre todos os cineastas, ele é o único que usa a câmera simplesmente pelo que ela é: o terceiro olho, da iluminação... Ele simplesmente liga o terceiro olho e assiste à transfiguração do universo, levando-nos a participar disso". (Manara, apud: Fabris, 2004, p. 6).

Manoel de Barros conhece esse conceito de Milo Manara, pois define Fellini como o transfigurador de tudo (Barros, apud: Castro, 1992, p. 58). O poeta traz essa idéia para se referir ao seu próprio processo de criação. Em entrevista, afirma: Aprendi que o artista não vê apenas. Ele tem visões. A visão vem acompanhada de loucuras, de coisinhas à toa, de fantasias, de peraltagens. Eu vejo pouco. Uso mais ter visões. Nas visões vêm as imagens, todas as transfigurações. O poeta humaniza as coisas, o tempo, o vento. As coisas, como estão no mundo, de tanto vê-las nos dão tédio. Temos que arrumar novos comportamentos para as coisas. [Barros, 2006, p. 30].

Transfigurar e inventar seus próprios retratos, essas duas tarefas são muito caras ao poeta brasileiro e ao diretor italiano. O sujeito poético de Matéria de poesia afirma: Me inventei [MP - 189]; em Livro sobre nada, lê-se: Tudo que não invento é mentira. [LN - 67].

Fellini afirmou: Inventei quase tudo: uma infância, uma personalidade, saudades, sonhos, recordações, pelo prazer de poder narrá-los. [Fellini, apud: Fabris, 2004, p. 6]. Mariarosaria mostra que essa idéia é reiterada por Raymond Bellour, quando afirma que o diretor elaborou uma autobiografia sem amarras, desprovida de qualquer preocupação com a verdade. [Bellour, apud: Fabris, 2004, p. 6].

A força da invenção confunde Julieta, que em certo momento não sabe se o que vê e ouve são criações interiores. Essa dúvida se intensifica com a presença de uma psicanalista que aparece na casa da protagonista numa reunião festiva. 
Nessa ocasião, depois de mirar e escutar várias criaturas invisíveis e inaudíveis para os outros, Julieta, irritada, afirma: Vocês não os vêem? Não os ouvem? Vingue-se! Perdoe! Quem devo ouvir? Fique bonita. A vida é um sacrifício. Seja mulher. Você não leva jeito. É gente que fala, fala! Saiam todos! Vão embora.

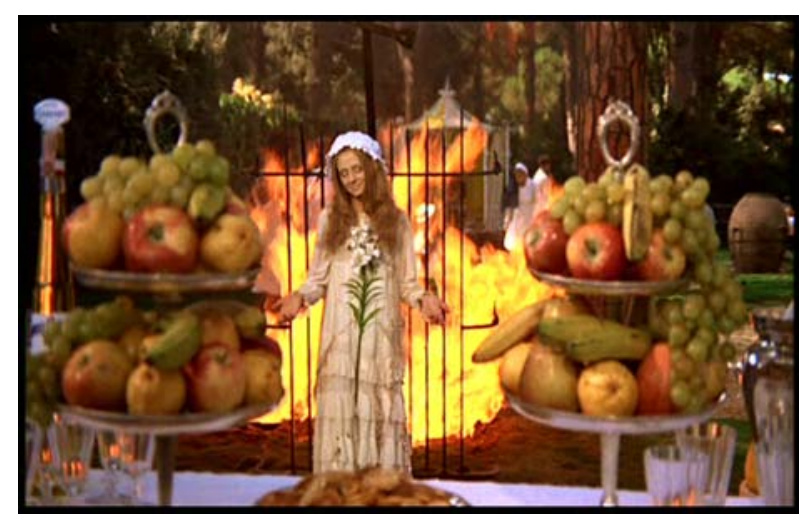

Uma das visões de Julieta.

Se Julieta muito vê e muito ouve, o contrário se dá com seu esposo, Giorgio. Relevante e metafórico, inclusive, é o modo como ele dorme: usa tapões nos ouvidos e vendas nos olhos. Ouvidos e olhos sensíveis são os de José, já que admira Diego Rivera, como se viu, e também toca músicas delicadas ao violão. Parece que esse espanhol pode oferecer a Julieta o que falta em seu marido: sensibilidade, presença e atenção, já que Giorgio sempre está ausente, atento aos lucros, aos negócios.

"Julieta dos espíritos" tem um inacabado epílogo. Ao final do filme, a protagonista, com uma roupa branca, aparece de costas.

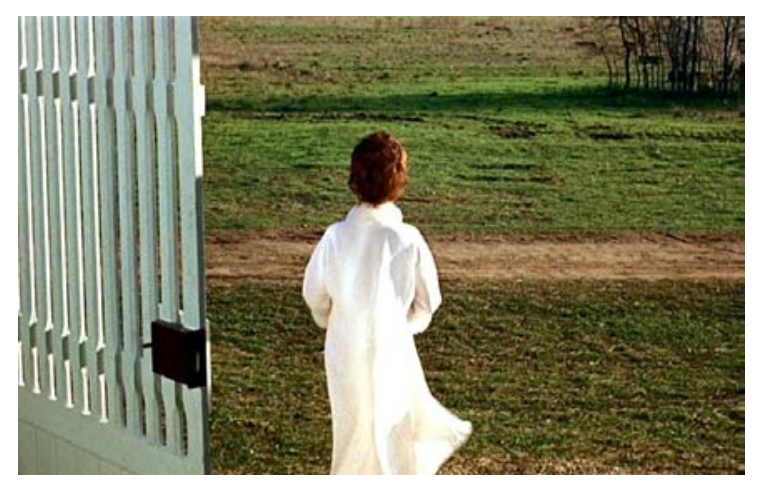

Fotograma do final de "Julieta dos espíritos". 
Isso mostra a circularidade da película, pois, como se viu, nas cenas iniciais, Julieta também aparece desse modo.

Sobre a ciclicidade em Fellini, Mariarosaria Fabris afirma: o cineasta dizia que rodava sempre o mesmo filme, o que explica porque abominava o letreiro "Fim": gostava de imaginar que suas criaturas seguissem adiante. Parece que estamos diante da seqüencia que fecha 8112 , quando as personagens se juntam no desfile final e a história não termina, pois o filme que Guido queria realizar começará ali. [Fabris, 2004, p. 6].

Também não há letreiro "Fim" em "Julieta dos espíritos", porque se trata de um epílogo em aberto: a saída de Julieta da sua casa pode significar um passeio ou a desistência da vida conjugal com Giorgio. Ela sai de casa e toma a direção da casa de Suzy, em que conheceu um belo jovem, numa festa. Há um outro possível novo amor para Julieta, o espanhol José. São várias as alternativas que se apresentam nesse inacabado filme.

$* * * * *$

Inacabada também é esta comparação entre Barros, Beckett e Fellini, porque como pássaros suas imagens nos convidam a alçar vôos no desconhecido, que é incansável e sempre nos procura. Infindos e adejantes são também os filmes de Akira Kurosawa, que faleceu no ano da publicação de Retrato do artista quando coisa. Fellini o admirava muito, principalmente por causa de "Os sete samurais". Toshiro Mifune, um dos atores preferidos do artista japonês, é mencionado no filme "Entrevista", do diretor italiano.

Toshiro aparece de costas no início e no fim de um filme, rodado quatro anos antes de "Julieta dos espíritos": "Yojimbo", de Kurosawa. Esse poeta cinematográfico do Japão e do mundo, afeito a ciclicidades, desenvolveu de modo profundo e sensível o tema do olhar, por isso no próximo capítulo será feita uma comparação entre ele e Barros. 


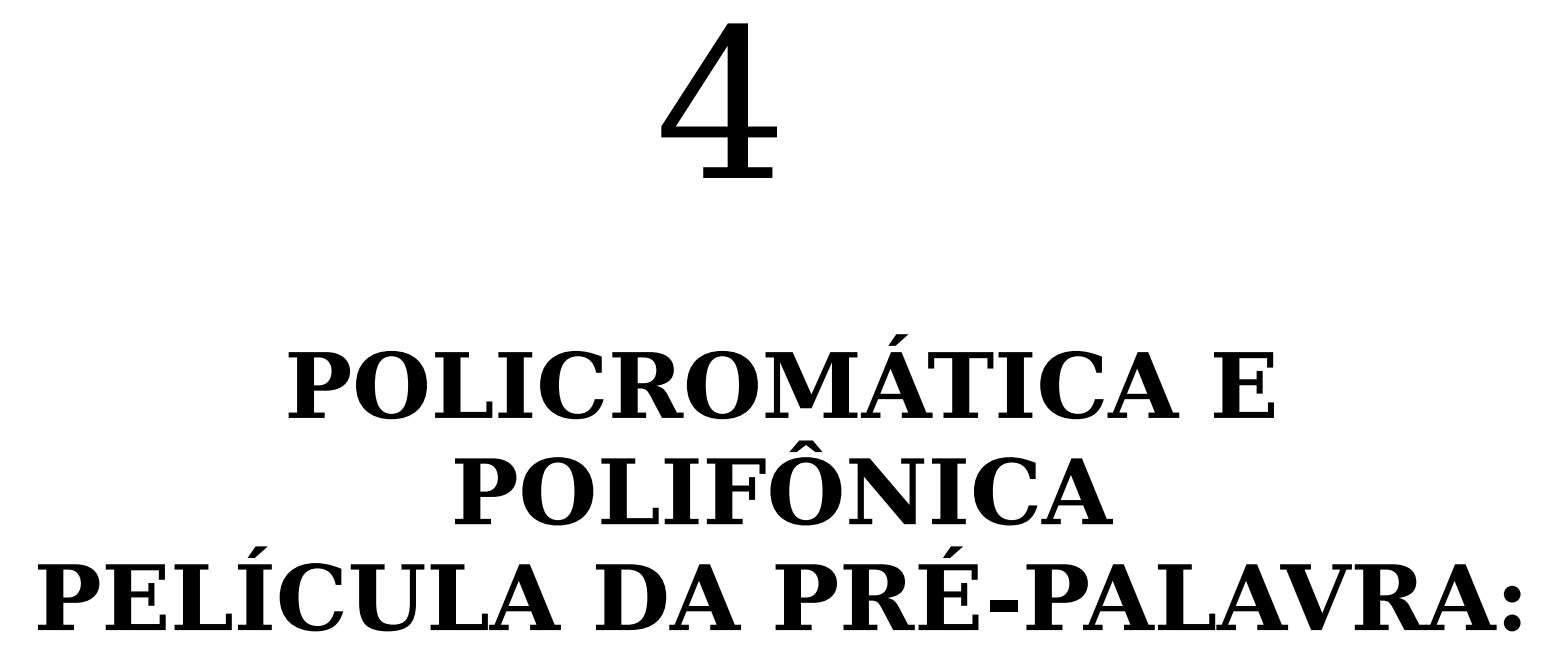

O LIVRO DAS IGNORÃÇAS (1993) 
13131

Quem me diz onde é que mora o amor, se é branco e preto ou tem cor, Se é sem fim o amor ou tem final feliz [...]. 
Nossa nave vai veloz tão bela, caravela faz-se mansa, mas feroz Nossa nave vai veloz e nós dizendo adeus, contando luas, sol a sol

Vem, amor pra que esse filme não termine, não se finde, vem sonhar. ["Pra cinema”, de Chico César].

\section{AUDÍVEIS IMAGENS DO NÃO SABER}

Tô estudando pra saber ignorar.

["Tô", de Tom Zé e Elton Medeiros].

O livro das ignorãças é obra de 1993. A fotógrafa Anna Mariani buscou a imagem dos vegetais, especificamente os do Pantanal, para criar a capa da edição da Record. Num fundo bege, o marrom aparece nas letras do título. $\mathrm{O}$ instantâneo deve ter sido trabalhado artisticamente, pois aparecem nele camadas de cores: a primeira, de cima para baixo, está entre e o cinza e o azul, a segunda é azul claro, a terceira é verde claro, a quarta é marrom, a quinta é novamente verde claro e a sexta e última é verde escuro.

\section{Manoel de Barros}

Capa da edição da Record de LI.

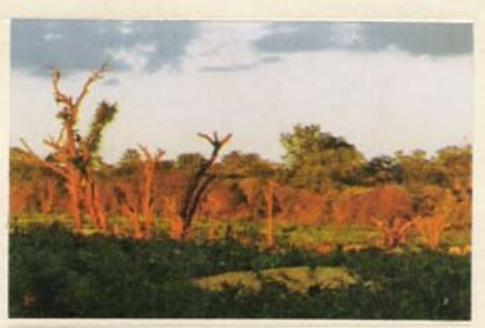

A obra está dividida em três partes: “Uma didática da O LIVRO DAS
IGNOR ACCAS invenção", "Os delimites da palavra" e "Mundo 
pequeno". E, para cada seção, há um desenho feito por Manoel de Barros.

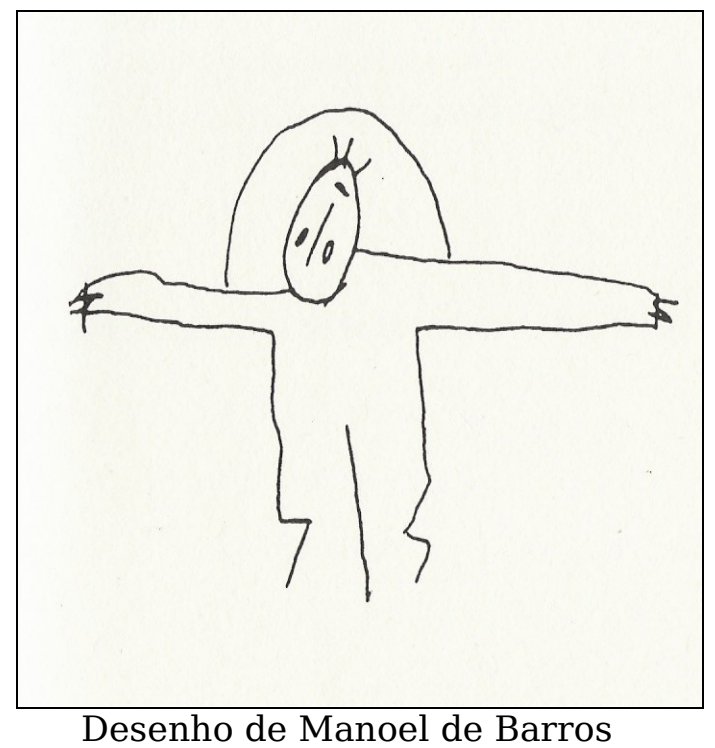

Nessa primeira imagem, aparece um homem, que tem atrás de si um sol, seus braços parecem morros, seu tronco e seus pés lembram um rio. Assim, como na poesia manoelina, o ser humano se amalgama com os outros elementos

da natureza.

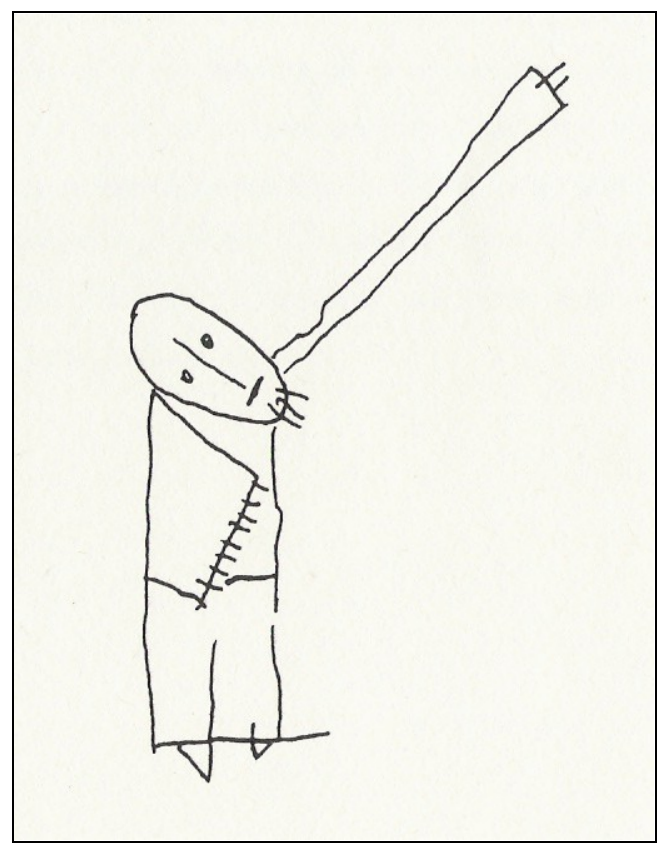

Aqui, Barros mostra um homem com um braço curto e o outro longo, o que pode ser uma metáfora que representa o horror à simetria da escrita manoelina ou a idéia, que vem da Antiguidade, de que o poeta é um mediador entre a esfera 
13134

terrena e a divina.

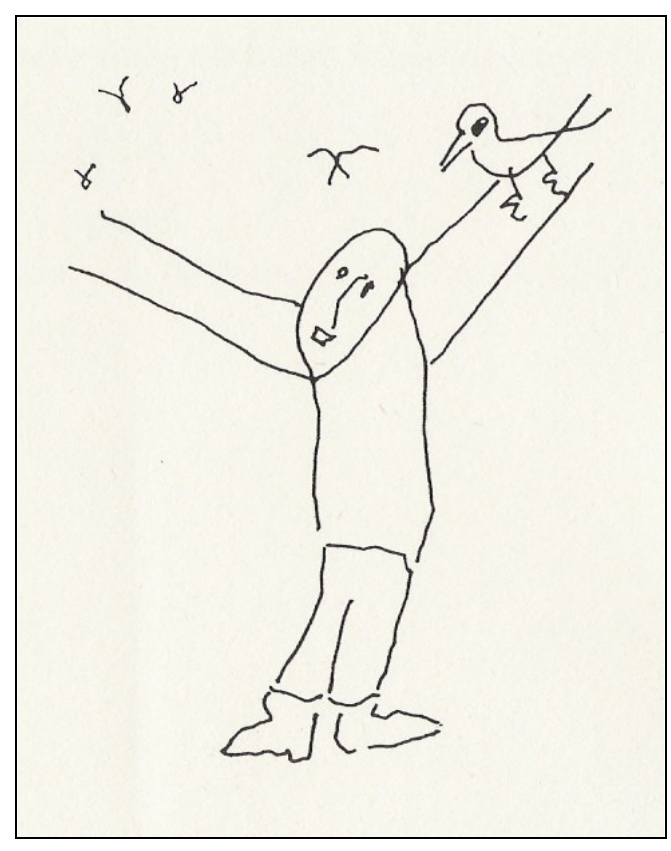

O outro desenho apresenta um homem-árvore, com um pássaro em seu braço-galho. No alto, no céu, aparecem outros muitos pássaros. Os braços-galhos são inacabados.

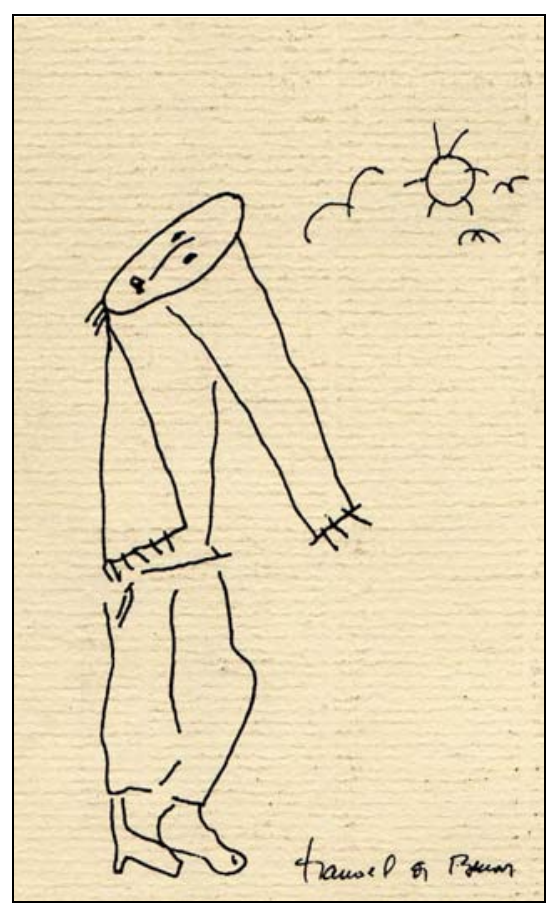


Nessa imagem, que está na quarta capa de O livro das ignorãças, aparece um homem com um pé humano e o outro parece de um animal, o de um papagaio talvez.

Assim, tem-se o retrato do artista quando pássaro [que aparece nos dois últimos desenhos] e também o retrato do artista quando lesma/parede:

Toda vez que encontro uma parede

Ela me entrega às suas lesmas.

Não sei se isso é uma repetição de mim ou das

lesmas.

Não sei se isso é uma repetição das paredes ou de mim.

Estarei incluído nas lesmas ou nas paredes?

Parece que lesma só é uma divulgação de mim.

Penso que dentro de minha casca

Não tem um bicho:

Tem um silêncio feroz.

Estico a timidez de minha lesma até gozar na pedra. [LI - 89].

Antes de ser citado em Retrato do artista quando coisa, Rodin já era mencionado em $O$ livro das ignorãças. O sujeito poético ouve os clamores do silêncio das suas pedras: Adoecer de nós a Natureza: - Botar aflição nas pedras (Como fez Rodin). (LI - 19).

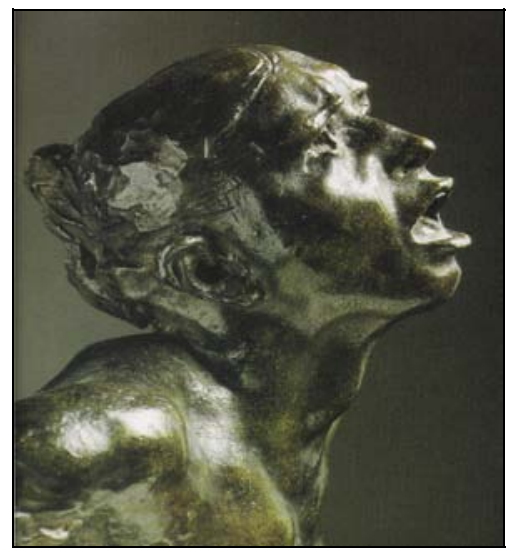

"O grito", de Auguste Rodin

O mutismo da escuta é recorrente, nesse livro: Só escuto as paisagens há mil anos (LI - 65). O sujeito poético está atento à ausência e à presença dos 
ruídos naturais não escapam: A lua faz silêncio para os pássaros, - eu escuto esse escândalo! (LI - 69). Se o homem ouve o silêncio da natureza o contrário também se dá: Os passarinhos ouvem o silêncio de Bernardo: Silêncio dele é tão alto que os passarinhos ouvem de longe. (LI - 97).

$\mathrm{Na}$ orelha do livro, Ênio Silveira afirma que o resultado da literatura de Barros é desconcertantemente multifacetado, variando do telúrico ao surrealista, da precisão descritiva à mais arrebatadora das metáforas, do lírico ao grotesco. [Silveira, Ênio. Orelha de LI].

O grotesco aparece neste poema do livro: Aos blocos semânticos dar equilíbrio. Onde o abstrato entre, amarre com arame. Ao lado de um primal deixe um termo erudito. Aplique na aridez intumescências. Encoste um cago ao sublime. E no solene um pênis sujo. [LI - 21].

Ênio adverte, na orelha de $O$ livro das ignorãças: não se pode classificar Barros como "o Guimarães Rosa da poesia”, porque Rosa é Rosa, Manoel é Manoel.

Como se viu, na fortuna crítica de Barros, apresentada no primeiro capítulo desta tese, alguns críticos perceberam várias diferenças entre os escritos manoelinos e rosianos. Luiz Henrique Barbosa, por exemplo, afirma que a vontade de chegar ao grau zero de uma palavra [Barbosa, 2003, p. 18] é exclusiva de Manoel.

Esse grau zero de uma palavra é buscado em O livro das ignorãças:

Minha voz inaugura os sussurros. [LI - 63].

No começo era o silêncio:

O mundo não foi feito em alfabeto. Senão que primeiro em água e luz. [LI - 95].

Água e luz antecedem o verbo, ocorrendo, em $O$ livro das ignorãças, o inverso do que se dá na Bíblia, pois nesta vê-se a anterioridade da palavra com relação à criação das coisas [Deus disse: "Haja luz e houve luz". $\left.{ }^{30}\right]$.

Vejamos o poema inteiro:

$30 \quad$ Bíblia de Jerusalém, p. 218. 
O mundo não foi feito em alfabeto. Senão que primeiro em água e luz. Depois árvore. Depois lagartixas. Apareceu um homem na beira do rio. Apareceu uma ave na beira do rio. Apareceu a concha. E o mar estava na concha. A pedra foi descoberta por um índio. $O$ índio fez fósforo da pedra e inventou o fogo pra gente fazer bóia. Um menino escutava o verme de uma planta, que era pardo. Sonhava-se muito com pererecas e com mulheres. As moscas davam flor em março. Depois eoncontramos com a alma da chuva que vinha do lado da Bolívia - e demos no pé.

(Rogaciano era índio guató eme contou essa cosmologia.) [LI - 95].

O sujeito poético ouve essa cosmologia de um índio guató, que contraria a gênese bíblica. Entre a leitura e a escuta, esse "eu" opta pela segunda, entre a escrita bíblica e o mito indígena falado, ele também prefere a segunda possibilidade. Assim, o silêncio audiente se intensifica: o sujeito poético ouve o guató e o menino do mito escuta o verme de uma planta.

Se o mundo não surgiu a partir da água e da luz, ele, então, nasceu da concha: De primeiro as coisas só davam aspecto/ Não davam idéias. A língua era incorporante./ Mulhere não tinham caminho de criança sair/ Era só concha. [LI 85].

Em nota de rodapé, aparece a seguinte explicação, com relação ao último verso: Era só concha: está nas Lendas em Nheengatu e Português, na Revista do Instituto Histórico Geográfico Brasileiro, v. 154. [LI - 85].

Aparece, em $O$ livro das ignorãças, o silêncio da leitura:

$\mathrm{Na}$ enchente de 22, a maior de todas as enchentes do Pantanal, canoeiro Apuleio vogou três dias e três noites por cima das águas, sem comer sem dormir $-e$ teve um delírio frásico. A estórea aconteceu que um dia, remexendo papéis na Biblioteca do Centro de Criadores da Nhecolândia, em Corumbá, dei com um pequeno Caderno de Armazém, onde se anotavam compras fiadas de arroz feijão fumo etc. Nas últimas folhas do caderno achei frases soltas, cerca de 200. Levei o manuscrito para casa. Lendo as frases com vagar imaginei que o desolo a fraqueza e o medo talvez 
tenham provocado, no canoeiro, uma ruptura com a normalidade. Passei anos penteando e desarrumando as frases. Desarrumei o melhor que pude. $O$ resultado ficou esse. Desconfio que, nesse caderno, o canoeiro voou fora da asa. [LI-31].

Assim, o "eu" poético segue penteando e desarrumando as frases de Apuleio (o canoeiro do Pantanal que voou fora da asa em seus escritos de 1922) que por sua vez dialoga com um outro Apuleio (o latino Lúcio, do século II AC, autor de $O$ asno de ouro) não só porque são homônimos, mas também porque um menciona o outro: Eu hei de nome Apuleio./ Esse cujo eu ganhei por sacramento./ Os nomes já vem com unha?/ Meu vulgo é Seo Adejunto - de dantes/ cabo-adjunto por servimentos em quartéis./ Não tenho proporções para apuleios. Meu asno não é de ouro. [...]. [LI - 35].

O Apuleio pantaneiro escreveu, ou melhor, reescreveu, um texto em 1922. Parece que aqui está presente o silêncio da elipse, pois não há nenhuma menção, ao longo do livro manoelino, a Oswald de Andrade, James Joyce e T. S. Eliot. No entanto, 1922 é um ano especialíssimo para a literatura modernista, já que nele ocorreram a Semana da Arte Moderna Brasileira e as publicações de Ulysses, de Joyce, e de "The waste land" ("A terra desolada"), de Eliot.

Oswald e outros propuseram uma visão (e audição) pautada na Antropofagia. Manoel de Barros, em entrevista, afirma ter conhecido os textos oswaldianos, quando adolescente, e utiliza, nesse mesmo relato, os termos intertextos e subtextos:

Com 17 anos, talvez foi que conheci o Oswald de Andrade - e Rimbaud. O primeiro me confirmou que o trabalho poético consiste em modificar a língua. E Rimbaud me incentivou com imense dérèglement de tous les sens. Para um bicho do mato criado em quintal de casa, para um ente arisco, medroso das gentes e dos relâmpagos, bolinador de paredes pelas quais se esgueirava - esse Rimbaud foi a revolução. [...]. Falo daquele desregramento a que se referiu Rimbaud e que ilumina as nossas loucuras. Penso que os sub-textos e intertextos resultam de uma perversão sensorial. [PQT 325].

Esse "primitivo"/bugre bicho do mato põe-se a devorar Rimbaud bem como 
Andrade e o resultado pode ser notado em O livro das ignorãças. As sinestesias, tão ao gosto rimbaudiano, pululam nessa obra:

Hoje eu desenho o cheiro das árvores [LI - 17].

Escuto a cor dos peixes. [LI - 51].

Cheiroso som de asas vem do sul. [LI - 53].

Ouço o tamanho oblíquo de uma folha. [LI - 55].

Quero apalpar o som das violetas. [LI - 59].

Um perfume vermelho me pensou. [LI - 69].

A oswaldiana proposta cabocla-moderna de aproximar a literatura do falar popular pode ser notada nesse escrito de Barros: Respeito as oralidades [LI 47]. E mais:

Ocupo muito de mim com o meu desconhecer.

Sou um sujeito letrado em dicionários.

Não tenho que 100 palavras.

Pelo menos uma vez por dia me vou no Morais ou no Viterbo -

A fim de consertar a minha ignorãça, mas só acrescenta.

Despesas para minha erudição tiro nos almanaques:

- Ser ou não ser, eis a questão.

Ou na porta dos cemitérios:

- Lembra que és pó e que ao pó tu voltarás.

Ou no verso das folhinhas:

- Conhece-te a ti mesmo.

Ou na boca do povinho:

- Coisa que não acaba no mundo é gente besta

e pau seco.

Etc

Etc

Etc

Maior que o infinito é a encomenda

[LI - 27]. 
A frase do "povinho" (o diminutivo deve ser entendido aqui não como desprezo, mas como uma referência carinhosa) fica no mesmo patamar de importância das citações cultas: Hamlet, Gênesis bíblico e Sócrates.

Não sou sandeu de gramática, afirma o sujeito poético de O livro das ignorãças, valorizando as estruturas lingüísticas populares. Quando essa obra foi editada em 1993, Manoel, em entrevista à Folha de São Paulo, afirmou: O choque do erudito com o primitivo, minha poesia tem muito isso. A boa literatura e a boa linguagem do povo. Câmara Cascudo dizia que o povo é uma universidade ${ }^{31}$.

O gosto do sujeito poético por seres pobres e anônimos o conduz na escolha das epígrafes. Na seção inicial, o desconhecido e inventado Felisdônio, que o leitor reencontrará num poema do livro, é o autor deste verso: As coisas que não existem são mais bonitas. A segunda parte não tem epígrafe e, na terceira seção, Sombra-Boa afirma: Aromas de tomilho dementam cigarra.

Há um poema na última parte do livro, em que Sombra-Boa e esse seu verso reaparecem. Tal escrito será analisado a seguir.

31 Manoel de Barros em entrevista. Couto, J. G. "Manoel de Barros busca na ignorância a fonte da poesia". Folha de São Paulo, 14/11/1993, p. 8-9, Livros. 


\title{
AZULÁCEA E AMARELA ANTE-PALAVRA
}

\author{
Ah como são verdes \\ os espaços em branco da minha alma. \\ [Cuidado silêncios soltos, \\ de Mário Jorge].
}

Caçador, nos barrancos, de rãs entardecidas, Sombra-Boa entardece. Caminha sobre estratos de Um mar extinto. Caminha sobre as conchas dos caracoes da terra. Certa vez encontrou uma voz sem boca. Era uma voz pequena e azul. Não tinha boca mesmo. "Sonora voz de uma concha", ele disse. Sombra-Boa ainda ouve nestes lugares conversamentos de gaivotas. E passam navios caranguejeiros por ele, carregados de lodo. Sombra-Boa tem hora que entra em pura decomposição lírica: "Aromas de tomilhos dementam cigarras." Conversava em Guató, em Português, e em Pássaro.

Me disse em língua-pássaro: "Anhumas premunem Mulheres grávidas, três dias antes do inturgescer.". Sombra-Boa ainda fala de suas descobertas:

"Borboletas de franjas amarelas são fascinadas por Dejectos." Foi sempre um ente abençoado a garças. Nascera engrandecido de nadezas. [LI - 81].

Nos primeiros versos, há aliteração em $\boldsymbol{c}$ :

Caçador, nos barrancos, de rãs entardecidas, Sombra-Boa entardece. Caminha sobre estratos de

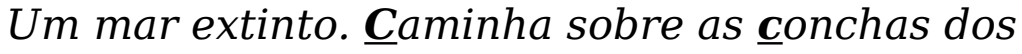
caracoes da terra. Certa vez encontrou uma voz sem boca. Era uma voz pequena e azul. Não tinha boc a mesmo. "Sonora voz de uma concha", ele disse. Sombra-Boa ainda ouve nestes lugares conversamentos de gaivotas. E passam navios

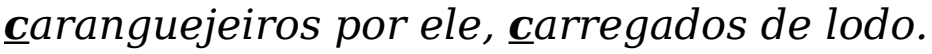

Ao entrar em contato com sua caça, Sombra-Boa assume suas características, ou seja, fica tão entardecido quanto as rãs que pega. Ele vaga 
sobre estratos de um mar extinto, ou seja, o Pantanal, antigo Mar de Xaraiés. O sujeito poético, para expressar a idéia de anterioridade, usa o termo antigo caracoes, ao invés de caracóis.

A linguagem de Sombra-Boa, além de buscar sonoridades atávicas, parece plena de obscuridades, inclusive a idéia de escureza já está presente no seu nome. Além disso, em outras passagens de $O$ livro das ignorãças, lê-se:

Há certas frases que se iluminam pelo opaco. [LI - 23].

Aceito no meu fado o escurecer. [LI - 49].

O infinito do escuro me perena [LI - 51].

O infinito do obscuro perenou um autor muito sensível ao não dito do subtexto: Anton Tchékhov. Elena Vássina, comentando suas peças, no ensaio "O eterno Tchékhov", afirma: O mais importante torna-se o subtexto - a ação não verbal que se desenrola na transformação da atmosfera de cada cena. [Vássina, 2004, p. 19].

O subtexto muitas vezes pauta-se em enigmas, como em "A gaivota":

Nina: Ultimamente, o senhor se irrita à toa, se expressa de um modo totalmente incompreensível, como se usasse símbolos. Veja aqui esta gaivota, também deve ser símbolo, ao que parece, mas me desculpe, eu não entendo... [Tchékhov, 2004, p. 44].

O escritor fictício, Trigórin, dessa peça tchekhoviana, faz o mesmo que vários autores reais: comunica-se numa linguagem enigmática. Sombra-Boa, realmente, é afeito, como Trigórin, a esse dizer desestabilizante e sombrio:

Sombra-Boa tem hora que entra em pura

decomposição lírica: "Aromas de tomilhos

dementam cigarras." Conversava em Guató, em

Português, e em Pássaro.

Me disse em língua-pássaro: "Anhumas premunem

Mulheres grávidas, três dias antes do inturgescer.". 
Além disso, ele, um cultuador do silêncio audiente, escuta as próprias gaivotas: Sombra-Boa ainda ouve nestes lugares/ conversamentos de gaivotas.

No conto tchekhoviano "Acontecimento", duas crianças, também, atentamente, escutam o dizer não verbal dos bichos. Nessa narrativa, os pequenos Vânia e Nina mantêm seu olhar por bastante tempo [Tchekhov, 2005, p. 150] na grande pequena novidade do dia: os filhotinhos da gata cinzenta com olhos verdes que criam. Passam praticamente o dia todo com os olhos vigilantes e amorosos naqueles pequenos seres:

- Que pequenos que são! - diz Nina, arregalando os olhos e sacudindo o corpo, numa alegre risada. - Parecem ratinhos. [Tchékhov, 2005, p. 149].

Mas esses minúsculos seres somem da sua visão: o pai, irritado com a sujeira que as crianças fizeram, tentando alimentar os filhotes, impede-as de ir à cozinha, onde estão os gatinhos. Depois, definitivamente, os pequenos rebentos não mais podem ser vistos pelas crianças: eles são devorados pelo cão Nero, que chega à casa com o tio dos meninos. Ao saberem disso, os pais de Nina e Vânia riem, o que gera estranhamento por parte dos infantes, cujo sentimento está próximo só ao do animal, ou seja, da aflita parturiente: Nero vai caminhando junto à mesa, agita a cauda e lambe-se, satisfeito consigo mesmo... Unicamente a gata está intranqüila. Andando de rabo espichado, olha com desconfiança para as pessoas e mia tristemente. [Tchekhov, 2005, p. 153-154].

O miado da gata sem palavras expressa seu sentimento, o que é compreendido pelas crianças. A linguagem da compaixão, nesse conto, só é possível de ser difundida entre as crianças e esse animal, assim como o dizer das gaivotas é entendido por Sombra-Boa.

Para Jacques Derrida, em $O$ animal que logo sou, a linguagem dos bichos realmente é aquela que está mais próxima à da poesia. O pensador afirma: [...] um dia, há cerca de dez anos, dei a palavra ou dei lugar a um pequeno ouriço, um bebê ouriço, talvez, diante da questão O que é poesia? ${ }^{32}$ Pois o pensamento do animal, se pensamento houver, cabe à poesia. [Derrida, 2002, p. 22].

Uma família de felinos na poesia é mencionada por Derrida: "O gato", de

32 Derrida, J. “Che cos'è la poesia”: In: Points de suspension. Paris: Galilée, p. 303. (N. T.) 
Rilke, e "O gato", de Baudelaire, cujo olhar é associado ao da amada e há uma observação importante: Para dizer as mais longas frases, / Ela não tem necessidade das palavras. [Baudelaire, apud: Derrida, 2002, p. 21].

Derrida afirma que ao olhar, em silêncio, um gato, sente-se também olhado por ele, e, contrariando Descartes, percebe que, muitas vezes, vê o bicho como superior ao homem. A nudez, própria do animal, é geradora de incômodo pudoroso e depois de inveja nesse ser humano que olha e pensa.

O filosófo mostra que, para pensadores como o próprio Descartes e Kant, por exemplo, os animais não detinham linguagem nenhuma, eles estavam, pois, condenados ao silêncio, à mudez. No entanto, para Montaigne - que, segundo Derrida, é tanto pré-cartesiano como anticartesiano - os animais têm linguagem, só que não é a mesma do homem. Derrida observa que gato e silêncio se encontram em uma expressão popular: o gato comeu sua língua?

Retomando o conto "Acontecimento", Otto Maria Carpeaux, ao analisar esse escrito, encerra seu ensaio com as palavras de Biéli, indicando que o limite e o cinza dos contos tchekhovianos podem se abrir para a amplidão e para a rutilância: Os personagens de Tchekhov dizem coisas estúpidas e fazem coisas estúpidas; comem, dormem, vivem entre as suas quatro paredes e andam em caminhos cinzentos - mas esses caminhos cinzentos também são os da verdadeira Vida e podem levar a um ponto em que as quatro paredes já não nos apertam. Continuamos cinzentos; sua luz pode ser um crespúsculo sem remédio, mas esse crespúsculo também é um reflexo de espaços eternos. [Biéli, 1960, p. $66]$.

A eternidade e a abertura dos contos tchekhovianos são observadas por Elena Vassina, que mostra que esse escritor nunca sugere soluções para os problemas tão difíceis da vida, por isso, muitas obras não têm desfecho, terminam em reticências, como o fluxo natural da vida. Através do indefinido e do infinito, sempre presentes na narrativa de Tchekhov, suas obras ficam ligadas com a eternidade da própria vida, com aquela luz divina que sempre se sente nas verdadeiras obras de arte que ultrapassam o seu tempo. [Vássina, 2004, p. 16].

Elena percebe que no teatro se dá o mesmo: $O$ estado do espírito nos dramas de Tchekhov é exatamente aquilo que liga o instante presente com a 
eternidade, por isso suas peças sempre têm um final aberto. [Vássina, 2004, p. 19].

"A gaivota" é um exemplo disso, já que se "encerra" com o suicídio de Trigórin. O crítico Rubens Figueiredo, em posfácio da sua tradução desse drama, comenta: Em uma composição desse tipo, mesmo que sobrevenha ao final um acontecimento de impacto - como é o caso em A gaivota -, não haverá um desfecho propriamente dito. Tal acontecimento, por mais dramático que pareça, por mais sofrimento que concentre em si, não representa nem solução, nem desvelamento, nem catarse. $O$ espectador subentende que a mesma crise $e$ o mesmo desajuste prosseguirão intactos e apenas se agravarão na vida futura dos personagens. [Figueiredo, 2004, p. 110].

Tchekhov afirmou que encerrou essa peça em pianíssimo e usava a mesma estratégia para seus contos, que tinham uma estrutura diferente daquela proposta anteriormente por Edgar Alan Poe. A tendência do autor russo é de contrariar a receita de "Filosofia da composição", do escritor norte-americano, para quem os contos deviam ter final em fortíssimo, ou seja, deviam ser conclusivos ou apoteóticos e sua qualidade seria medida a partir da sua capacidade de prender a atenção do leitor, que deveria lê-los em uma só assentada [Poe, 2000, p. 40]. Poe entende que seu texto "O corvo" segue essa receita.

Os urubus manoelinos são parentes não dos corvos poeanos mas das gaivotas tchekhovianas, ou seja, a força dos escritos de Barros está no seu final que aclama a inconclusibilidade como os epílogos do autor russo ${ }^{33}$. Em Tratado

\footnotetext{
33 Tchékhov mostra sua maestria no final em pianíssimo, o que se pode notar em "Uma criatura enigmática". Nessa narrativa, aparecem uma personagem feminina sem nome e, justamente, um escritor de contos, que se encontram em um trem. O final da narrativa é este: $O$ leque quebrado cobre o rostinho bonito. $O$ escritor apóia a cabeça cheia de pensamentos, suspira e põe-se a meditar com ar de psicólogo experimentado. A locomotiva apita e solta um longo chio de vapor, enquanto o sol poente tinge de vermelho as cortinhinhas da janela... (Tchekhov, 1991, p. 15). Na metade do conto, a portadora do leque quebrado e do rostinho bonito comenta ao escritor de contos que se sente como um personagem dostoievskiano: Eu sou uma sofredora bem ao estilo de Dostoiévski... (Tchekhov, 1991, p. 13). A natureza enigmática desse conto está na forma do escrito, já que as reticências estão no seu meio, pedindo ao leitor para ler Dostoiévski nas suas entrelinhas, bem como no final, silenciando sobre muitos dos significados da personalidade da personagem principal. Entregue à mudez da reflexão, o escritor pensa nas palavras daquela mulher que havia se casado com um militar que não amava para tirar sua família da miséria. Quando ele morreu, sentiu-se livre, mas novamente arranjou um problema: - Um outro velho rico... [Tchekhov, 1991, p. 15].
} 
geral das grandezas do ínfimo, Sabastião ouve conversamentos dos urubus:

O URUBUZEIRO

Meu amigo Sabastião estourou a infância dele $e$ mais duas pernas

No mergulho contra uma pedra na Cacimba da Saúde. Quarenta anos mais tarde Sabastião remava uma canoa

no rio Paraguaio

E deu o barranco de uma charqueada.

Sabastião subiu o barranco se arrastando como um

caranguejo trôpego

Até a casa do patrão e pediu um trabalho.

O patrão olhou para aquele pedaço de pessoa $e$ disse:

Você me serve para urubuzeiro.

(Urubuzeiro era tarefa de espantar os urubus que atentavam nos tendais de carne.)

Trabalho de Sabastião era espantar os urubus.

Sabastião espantava espantava espantava.

Os urubus voltavam de bandos.

Sabastião espantava espantava.

Um dia pegaram Sabastião a prosear em estrangeiro

com os urubus.

Chegou que Sabastião permitiu que os urubus

fizessem farra nas carnes.

Os urubus faziam farra e conversavam em estrangeiro

com Sabastião.

Veio o patrão e mandou Sabastião para o manicômio.

No manicômio ninguém compreendia a língua de

Sabastião

De forma que Sabastião despencou do seu normal

E foi encontrado na rua falando sozinho em

estrangeiro. [TGGI - 21-22].

Esse texto é um híbrido de poema e de prosa. Assim, aparecem aliterações, típicas da poesia:

Chegou que Sabastião permitiu que os urubus

fizessem farra nas carnes.

Os urubus faziam farra e conversavam em estrangeiro

com Sabastião.

[TGGI - 21]. 
Até a casa do patrão e pediu um trabalho.

O patrão olhou para aquele pedaço de pessoa

[...]

Sabastião espantava espantava.

Um dia pegaram Sabastião a prosear em estrangeiro

com os urubus. [TGGI - 21].

$\underline{\mathbf{S}}$ abastião $\underline{\mathbf{s}}$ ubiu o barranco $\underline{\mathbf{s}}$ e arrastando [TGGI 21].

(Urubuzeiro era tarefa de espantar os urubus que atentavam nos tendais de carne.)

Trabalho de Sabastião era espantar os urubus.

Sabastião espanțava espantava espantava.

Os urubus voltavam de bandos.

Sabastião espanțava espantava

Há também assonâncias:

(Urubuzeiro $\underline{\boldsymbol{e}}$ ra tarefa de $\underline{\boldsymbol{e}}$ espantar os urubus que

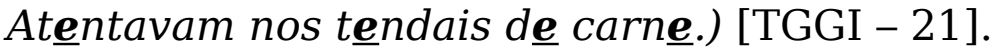

[...]

$\underline{\boldsymbol{E}}$ foi $\underline{\boldsymbol{e}}$ ncontrado na rua falando sozinho $\underline{\boldsymbol{e}} \mathrm{m}$ estrangeiro. [TGGI - 21-22].

Ocorrem não só repetições de fonemas, mas também de palavras:

Até a casa do patrão e pediu um trabalho.

$O$ patrão olhou para aquele pedaço de pessoa $e$ disse:

Você me serve para urubuzeiro.

(Urubuzeiro era tarefa de espantar os urubus que

Atentavam nos tendais de carne). [TGGI - 21].

Veio o patrão e mandou Sabastião para o manicômio.

No manicômio ninguém compreendia a língua de Sabastião 
Sabastião espantava espantava espantava.

Os urubus voltavam de bandos.

Sabastião espantava espantava. [TGGI - 21].

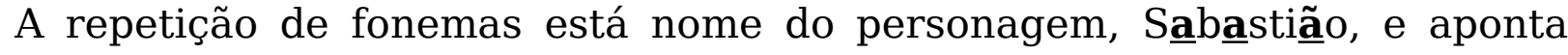
para o câmbio de $E$ para $A$, ou seja, o que seria Sebastião tornou-se Sabastião. Essa dinâmica de mudança de fonemas é muito comum na fala popular, isso significa que não se trata de um bem nascido. Essa alteração pode destacar, também, a proposta manoelina, já vista, de volta para o início, já que o $A$ é o início do alfabeto.

Com um fluir narrativo curto, "O urubuzeiro" tem parentesco com o gênero conto. Ele apresenta o personagem Sabastião, que, contraditoriamente, teve o corpo acidentado na Cacimba da Saúde, perdendo sua infância e suas pernas ao se chocar com uma pedra desse lugar, localizado no município de Corumbá.

A aproximação do reino hominal com o mineral é muito recorrente na obra manoelina, só que, nesse caso, ela ocorre de modo dramático. Por causa desse fato catastrófico, Sabastião torna-se um misto de homem e animal, na comparação do enunciador: Sabastião subiu o barranco se arrastando como um caranguejo trôpego. [TGGI - 21].

O parentesco de Sabastião com os bichos se intensifica, quando ele consegue o emprego de urubuzeiro. Assim, cuida as carnes de bois abatidos e tem como função afastar os urubus que querem devorá-las. No início espanta esses animais, mas não demora a permitir que se aproximem dele, entregandose a fluidos diálogos, compreensíveis apenas para eles mesmos: Um dia pegaram Sabastião a prosear em estrangeiro/ com os urubus./ Chegou que Sabastião permitiu que os urubus/ fizessem farra nas carnes./ Os urubus faziam farra e conversavam em estrangeiro/ com Sabastião./ [...]. [TGGI - 21-22].

A imagem do urubu associa-se à morte já que esse bicho busca corpos sem vida. Além disso, a letra $u$, que aparece três vezes nessa palavra, $\underline{\mathbf{u}} \underline{\mathbf{u}} b \underline{\mathbf{u}}$, pode indicar término, já que é a derradeira vogal do alfabeto. Sabastião sofre por duas mortes: a da sua infância e a da suas pernas. 
O caranguejo é um ser anfíbio, o que pode, no plano das metáforas, associar-se com a mobilidade e a ambigüidade. O texto de Barros apresenta esses dois elementos, pois sendo tão curto gera vacâncias semânticas, promove a possilidade de mais de uma interpretação, assim como os contos de Tchékhov.

No gênero conto, escreve-se menos para significar mais; quanto mais o texto diminui, mas aparecem os silêncios nos seus desvãos e não se apreendem, na primeira leitura, os seus sentidos mais fundos: são necessárias leituras vindouras, para apreendê-los. O texto não se esgota, portanto, com o ponto final, porque ele está propício às reticências, mesmo que elas não estejam grafadas. Às vezes, o ponto de interrogação cumpre a mesma função das reticências, como neste poema de $O$ livro das ignorãças:

Bernardo é quase árvore.

Silêncio dele é tão alto que os passarinhos ouvem

De longe.

E vêm pousar em seu ombro.

Seu olho renova as tardes.

Guarda num velho baú seus instrumentos de

Trabalho:

1 abridor de amanhecer

1 prego que farfalha

1 encolhedor de rios - $e$

1 esticador de horizontes.

(Bernardo consegue esticar o horizonte usando três

Fios de teias de aranha. A coisa fica bem esticada.)

Bernardo desregula a natureza:

Seu olho aumenta o poente.

(Pode um homem enriquecer a natureza com a sua

Incompletude?) [LI - 97].

Encerrar um texto com um questionamento e com a idéia de incompletude sendo evidenciada é não encerrá-lo. O inacabamento é uma das características mais importantes de Anton Tchékhov, como aponta Andrei Kofman: Tchekhov tira do tempo algo não acabado ${ }^{34}$.

34 Essa afirmação de Andrei foi feita no curso de pós-graduação "A imagem artística do mundo na literatura russa do século XIX", realizado no segundo semestre de 2005, na Universidade de São Paulo. 
O gênero conto por si já é afeito ao silêncio do inacabado, já que, ao eliminar muitas palavras, busca o suscinto e acaba por incidir nas elipses, apresentando ao leitor personagens em situações tão fundamentais, quanto, muitas vezes, enigmáticas.

É isso que se percebe em "O encontro de Pedro com o nojo", do livro Poesias, de Manoel de Barros. Nessa curta narrativa, as reticências não estão visíveis ao leitor, mas estão presentes ao seu final. É feita uma pergunta: Poderemos sequer fazer uma idéia de que resultará do encontro de um homem com o nojo? [P - 120].

No parágrafo seguinte, não aparece uma resposta e sim uma ação vaga deixando também vaguidão ao leitor, que fica com a pergunta do parágrafo anterior retumbando em sua mente. O enigma está posto.

"O encontro de Pedro com o nojo" dialoga com um conto tchekhoviano intitulado "Angústia". É isso o que sente o protagonista manoelino a partir do momento em que passa a ouvir um samba queixoso, que inunda as ruas da cidade do Rio de Janeiro: o negro atropelava as pessoas com as suas queixas que escorriam pelas ruas como águas. Pedro foi saqueado pela angústia. [P - 118].

Em "Angústia", esse sentimento tem também proporções de enchente:

a multidão corre, sem reparar nele, nem na sua angústia... Uma angústia imensa, que não conhece fronteiras. Dá a impressão de que, se o peito de Iona estourasse e dele fluísse para fora aquela angústia, daria pra inundar o mundo. [Tchékhov, 2005, p. 136].

"Angústia" conta a história do cocheiro Iona Potapov, que anseia por um diálogo com algum de seus passageiros, pois seu filho morreu e ele quer desabafar sua dor, conversar sobre os detalhes do passamento. São várias as suas tentativas para conseguir um interlocutor, mas as pessoas, tão ensimesmadas, não querem ouvi-lo.

O texto apresenta um final surpreendente:

- Assim é, irmão, minha egüinha... Não existe mais Kuzmá Iônitch... [...]. Agora, vamos dizer, você tem um potrinho, que é teu filho... E, de repente, vamos dizer, esse mesmo potrinho vai para o outro mundo... Dá pena, não é verdade? 
O cavalinho vai mastigando, escuta e sopra na mão de seu amo... Iona anima-se e conta-lhe tudo... [Tchékhov, 1999, p. 138].

Assim como o rocim de Iona oferece a ele o silêncio da escuta também os urubus ouvem Sabastião. A dor de Sabastião é parecida com a de Iona: também é o óbito que gera seu sofrimento: o da sua infância e o das suas pernas. A conversa com urubus fez com que seu patrão o enviasse ao manicômio e lá ninguém o entendia. O silêncio da incomunicabilidade intensifica a solidão de Sabastião e, ao final da história, afastado dos seus únicos interlocutores, os urubus, Sabastião despencou do seu normal e foi encontrado na rua falando sozinho em estrangeiro [TGGI -22].

O epílogo de "O urubuzeiro" apresenta uma ação em andamento, afinal, o último verbo está no gerúndio: falando [TGGI -22].

Iona, ao final do conto, pronuncia três termos no diminutivo: egüinha, potrinho e cavalinho. Como essas palavras são dirigidas a seu animal, isso pode revelar o tom amoroso do protagonista ao se manifestar com o bicho, mas há um outro sentido que o texto pode guardar em suas camadas mais profundas: o cavalo, mesmo sendo um animal de médio porte, é mencionado como um ser pequeno, talvez revelando o modo como é visto pela sociedade. Como Iona se sente pequeno, pela morte do filho e por sua dor ser ignorada, diminuída por aqueles que conduziu durante o dia, já que não quiseram ouvi-la, ele se refere ao seu igual usando o diminutivo.

No poema em análise, Sombra-Boa encontra uma voz pequena, como a de Iona, que é mostrado como um ser mínimo bem antes do final da história, já que em uma passagem anterior o narrador mostra que a angústia do cocheiro é enorme, mas não é visível. Ou seja, para ele próprio, ela é gigantesca, mas para os outros ela é diminuta, afinal quem quer saber as agruras de um pequeno cocheiro? Assim, lê-se:

Está novamente só e, de novo, o silêncio desce sobre ele... A angústia que amainara por algum tempo torna a aparecer, inflando-lhe o peito com redobrada força. Os olhos de Iona correm, inquietos e sofredores, pela multidão que se agita de ambos os lados da rua: não haverá, entre esses 
milhares de pessoas, uma ao menos que possa ouvi-lo? Mas a multidão corre, sem reparar nele, nem na sua angústia... Uma angústia imensa, que não conhece fronteiras. Dá a impressão de que, se o peito de Iona estourasse e dele fluísse para fora aquela angústia, daria pra inundar o mundo e, no entanto, não se pode vê-la. Conseguiu caber numa casca tão insignificante, que não se pode percebê-la mesmo de dia, com muita luz... [Tchékhov, 2005, p. 136].

A imensa angústia de Iona cabe numa minúscula casca. Os personagens tchekhovianos são convidados a constantes revisões das noções do grande e do pequeno, assim como os leitores dos textos desse autor.

Em "O bilhete premiado", isso ocorre com destaque. A história flagra Macha recolhendo os pratos do jantar e Ivan procurando no jornal o resultado lotérico. Para seu espanto e êxtase, a série comprada com o dinheiro da esposa é a premiada, falta apenas conferir o número do bilhete, o que não é feito; ao invés disso, o marido começa a fazer planejamentos com a possível "bolada":

A nossa série está aí - disse Ivan Dmítritch, depois de prolongado silêncio. [...]. Escuta, e se nós realmente ganhamos?

O casal pôs-se a rir e olharam-se por muito tempo, em silêncio. Aquela felicidade possível nublou-lhes o espírito, não podiam sequer sonhar, dizer para que precisavam daqueles 75.000, o que comprariam com aquilo, para onde viajariam [Tchekhov, 2005, p. 156].

O silêncio desse momento revela plenitude e amplitude: extasiados com a possibilidade do prêmio, os dois emudecem deixando-se levar pela fantasia, pelos planos futuros. O tempo que antes se arrastava numa ínfima porção do dia-a-dia que custava a passar agora acelera intenso como os pensamentos que lhes passam pela mente. O espaço restrito da cozinha, revelando uma vida pautada na economia, agora se espande na abastança e eles são transferidos, em pensamento, em direção a praias, a países outros como França, Itália, Índia.

Ao final do conto, tudo se reduz abruptamente, voltando ao universo minúsculo do início, quando Ivan lê os dois últimos números premiados: Série 9499 , bilhete 46 ! Não é 26 !

Assim, o tempo volta a se arrastar e o espaço se comprime: 
A esperança e o ódio desapareceram no mesmo instante $e$, imediatamente, pareceu a Ivan Dmítritch $e$ a sua mulher que seus quartos eram escuros, pequenos e baixos, que a ceia comida há pouco, não satisfazia e apenas fazia peso no estômago, que as noites eram longas e cacetes...

- E o diabo - disse Ivan Dmítritch, começando a implicar . - Por onde ando, piso sempre uns papeizinhos, migalhas, não sei que casquinhas. [Tchekhov, 2005, p. 160.]

Papeizinhos, casquinhas. A noção de pequenez está presente não só no vocabulário do conto, pleno de diminutivos, mas também no seu tamanho: são seis páginas, tanto na tradução de Boris Schnaideman, quanto na de Tatiana Belinky. Tais traduções evidenciam a economia e a polissemia desse conto, já que o próprio título é traduzido diferentemente: Tatiana optou por $O$ bilhete de loteria..$^{35}$

No posfácio de sua tradução, Boris mostra como o pouco dizer tanto do autor quanto dos personagens de "Bilhete premiado" ou "O bilhete de loteria" dá margem a muitas interpretações, evidenciando silêncios eloqüentes:

A concisão máxima faz com que um conto de quatro ou cinco páginas encerre uma infinidade de caminhos. Pensemos um pouco em "Bilhete premiado", [...]. Os silêncios, os olhares, os sorrisos, como tudo adquire importância neste pequeno episódio! Desde o maior encantamento até a máxima irritação e revolta, que mundo de sentimentos e sensações no íntimo daquele pequeno empregado! A figura de sua mulher não foi elaborada psicologicamente, mas os poucos olhares, as poucas palavras, são mais que suficientes para sugerir toda a situação entre ambos. ${ }^{36}$

O silente mirar que comunica muito e que está em "O bilhete premiado", como notou Schnaiderman, está presente também em "Angústia”: Iona, por estar conduzindo mal seu coche, acaba gerando um choque de seu cavalo com um

\footnotetext{
${ }^{35}$ Ambas as traduções foram publicadas primeiramente em 1958: a de Tatiana está no livro Histórias imortais e a de Boris está em A dama do cachorrinho e outros contos, editados , respectivamente, pela Cultrix e pela Civilização Brasileira.

${ }^{36}$ Scnaiderman, Boris. "Posfácio". In: Tchéchov, Anton. A dama do cachorrinho e outros contos. [Organização, tradução, posfácio e notas de Boris Schnaiderman] [5a edição] São Paulo: Ed. 34, 2005, p. 339.
} 
pedestre, que tem a seguinte reação: um transeunte, que atravessou a rua correndo e chocou-se com o ombro contra a cara do rocim, lança um olhar rancoroso e sacode a neve da manga. [Tchekhov, 2005, p. 133].

Sem palavras, apenas com um silencioso e rancoroso olhar fala-se muito. $A$ poética do olhar se estende em outros trechos de "Angústia", já que os olhos mudam de signficação a cada situação: Iona às vezes os apresenta tontos [Tchekhov, 2005, p. 133], às vezes, inquietos e sofredores [Tchekhov, 2005, p. 136] e seu cavalo ao final apresenta olhos brilhantes [Tchekhov, 2005, p. 138].

Essa passagem se dá logo depois que o cocheiro conduz três homens: dois altos e um baixo. Ocorre variação de altura de seus corpos, mas o desprezo e a frieza com relação ao luto de Iona é da mesma e enorme proporção. O mais baixo apresenta inclusive a mais alta falta de consideração para com o cocheiro, chegando a lhe dar um tapa:

- Esta semana... assim... perdi meu filho!

- Todos vamos morrer - suspira o corcunda, enxugando os lábios, após o acesso de tosse. Bem, bate nele, bate nele! Minha gente, decididamente, não posso continuar andando assim! Esta corrida não acaba mais?

- Você está ouvindo, velha peste? Vou te moer o pescoço de pancada! Não se pode fazer cerimônia com gente como você, senão é melhor andar a pé! Está ouvindo, Zmiéi Gorínitch? Ou você não se importa com o que a gente diz?

E Iona ouve, mais que sente, os sons de uma pancada no pescoço. [Tchékhov, 2005, p. 136].

Não tendo o silêncio da escuta de seus conduzidos, o pobre condutor emudece e ouve as ofensas a ele dirigidas. Chega também aos seus ouvidos uma pancada, que não é sentida.

O início do conto tchekhoviano mostra o protagonista mudo, diminuído, imóvel e coberto com a brancura da neve: $O$ cocheiro Iona Potapov está completamente branco, como um fantasma. Encolhido o mais que pode se encolher um corpo vivo, está sentado na boléia, sem se mover.

Também em plena brancura, imobilidade, pequenez e silêncio está seu cavalo: Seu rocim está igualmente branco e imóvel. Graças a sua imobilidade, à 
angulosidade das formas e ao perpendicular de estaca de suas patas, parece mesmo, de perto, um cavalinho de pão-de-ló de um copeque. [Tchekhov, 2005, p. 132].

Por causa de um defunto, o cocheiro torna-se um morto em vida, inclusive a frase Iona Potapov está completamente branco, como um fantasma pode ser uma observação ligada não só ao fato de ele estar coberto pela nívea brancura, mas pelo esfriamento de sua vontade de viver.

O branco pode ainda representar não só tal esfriamento, mas em termos textuais pode se associar à lacuna, ou seja, ao espaço em branco dos escritos tchekhovianos. Em uma missiva dirigida a Alekséi S. Suvórin, o autor russo afirma: Quando eu escrevo, confio inteiramente no leitor, supondo que ele próprio acrescentará os elementos subjetivos que faltam ao conto. [Tchekhov, 1995, p. 174].

Esse alvo mutismo da lacuna semântica está presente no poema "Zona hermética", do livro Poesias, de Barros: De repente, intrometem-se uns nacos de sonhos; [...]; Um rosto de moça cuspido no capim de borco; Um cheiro de magnólias secas. O poeta/ Procura compor esse inconsútil jorro;/ Arrumá-lo num poema; e o faz. E ao cabo/ Reluz com a sua obra. Que aconteceu? Isto:/ O homem não se desvendou, nem foi atingido:/ Na zona onde repousa em limos/ Aquele rosto cuspido e aquele/ Seco perfume de magnólias,/ Fez-se um silêncio branco... (P- 112).

Conversava em Guató, em/ Português, e em Pássaro. O dizer animal de $O$ livro das ignorãças evoca também capivaras, cágados e insetos, como as borboletas, que são extremamente plásticas, ou pelo seu colorido, ou pela sua forma. Mas, no caso desse poema, elas estão num contexto ligado ao grotesco: Sombra-Boa ainda fala de suas descobertas:/ "Borboletas de franjas amarelas são fascinadas por/Dejectos." Foi sempre um ente bençoado a garças./ Nascera engrandecido de nadezas. [LI - 81].

A borboleta, nesse poema de Barros, está distante de contextos românticos. Tal deslocamento também foi feito por Anton Tchekhov, em sua novela "A borboleta". Nela, esse inseto não é mencionado nenhuma vez, mas talvez Olga se sinta como tal, pois procura sempre impressionar as pessoas 
visualmente, seja por suas roupas, seja pelos seus croquis. Sente-se uma artista e deseja ser consagrada, imortal. Para ela, as opiniões de Ryabovsky sobre a sua arte são muito importantes e o leitor, depois de várias páginas, descobre que são amantes.

Numa noite vai à casa dele, entrando sem bater; percebe que há toda uma movimentação suspeita e nota que uma mulher correu e ficou atrás de um quadro, o que ela mesma já havia feito várias vezes. Nesse momento, Olga tentou identificar quem era, mas não pôde ver nada por causa das lágrimas e ela estava esmagada pela vergonha, sentindo-se como se ela não fosse mais Olga, mas sim um pequeno inseto. [Tchekhov, 1974, p. 17].

É improvável que ela se sinta como uma borboleta nessa situação; ela está mais próxima a uma daquelas baratas, que costumava ver andando sobre os portfolios, em baixo do banco, numa casa de campo, em que se reunia com seus amigos artistas.

O epílogo é amargo: o marido de Olga, que é médico, depois de contaminar-se no trabalho, aos poucos vai morrendo, mostrando uma dignidade que ela entende que não tem. Sente-se mais uma vez esmagada (como uma barata?), pois a inteireza do marido a faz se sentir pequena. Ele, mesmo sem falar, sabia do caso da sua esposa com Ryabovsky e resolve continuar a amá-la até a morte. No último parágrafo da narrativa, Korostelve, um médico amigo da família, fala para a empregada para chamar algumas mulheres que lavam corpos de cadáveres.

Borboleta e morte associam-se neste poema de $O$ livro das ignorãças: Para apalpar as intimidades do mundo é preciso saber: [...]. c) Por que é que as borboletas de tarjas vermelhas têm devoção por túmulos [LI - 9].

Neste texto, também, morte e borboleta estão próximas: Sentou-se na cama e, de maneira significativa, disse, em voz alta e em alemão: "Ich sterbe" Estou morrendo. Depois segurou o copo, voltou-se para mim, sorriu com seu maravilhoso sorriso e disse: "Faz muito tempo que não bebo champanhe." Bebeu tranquilamente todo o copo, estendeu-se em silêncio e, alguns instantes depois, calou-se para sempre. E a pavorosa calma da noite foi apenas alterada por uma enorme borboleta noturna, que entrou pela janela e voou, atordoada, pelo 
quarto, em torno das lâmpadas acesas. O médico retirou-se. No silêncio da noite, com um estampido terrível, a rolha da garrafa interminada saltou. Começou a clarear, e com a natureza a despertar, um primeiro réquiem: os doces e formosos cantos das aves e os acordes do órgão na igreja próxima. Nem uma voz humana, nada do cotidiano da vida, somente a calma e a grandeza da morte.

Esse escrito recebe o seguinte comentário de Fernando Sabino: Não, isto não é o fim de um conto de Tchekhov. É uma soberba descrição de seus últimos instantes de vida, feita pela própria esposa do escritor. [Sabino, apud: Tchekhov, 1987, p. 5-6].

Insetos e óbito se conjugam tanto na biografia quanto na ficção tchekhoviana. Na novela "Enfermaria n. 6", esse minúsculos seres estão num lugar em que a morte literal ou a morte em vida ronda. Em um hospital, pleno de percevejos e amoníaco [Tchekhov, 2005, p. 7], trabalha o médico Andriéi Efímitch Ráguin, que está em crise ao perseguir o verdadeiro sentido da vida, descontente com tudo. Deitado em sua cama, põe-se a pensar: $O$ passado é horrível, melhor não pensar nele. E o presente é igual ao passado. Ele sabe que enquanto os seus pensamentos giram em volta do sol, junto com a terra que se esfria aos poucos, ao lado de seu apartamento de serviço, no grande prédio, há gente sofrendo por doença e por imundície; um não dorme e luta contra os insetos, a erisipela faz o outro se revolver na cama [Tchékhov, 2005, p.38].

Os insetos são metáforas da gente miúda, com voz pequena. Essa voz no poema em análise, além de ser pequena é também azul.

A letras dessa palavra aparecem, em Concerto a céu aberto para solos de ave, em páginas diferentes. 

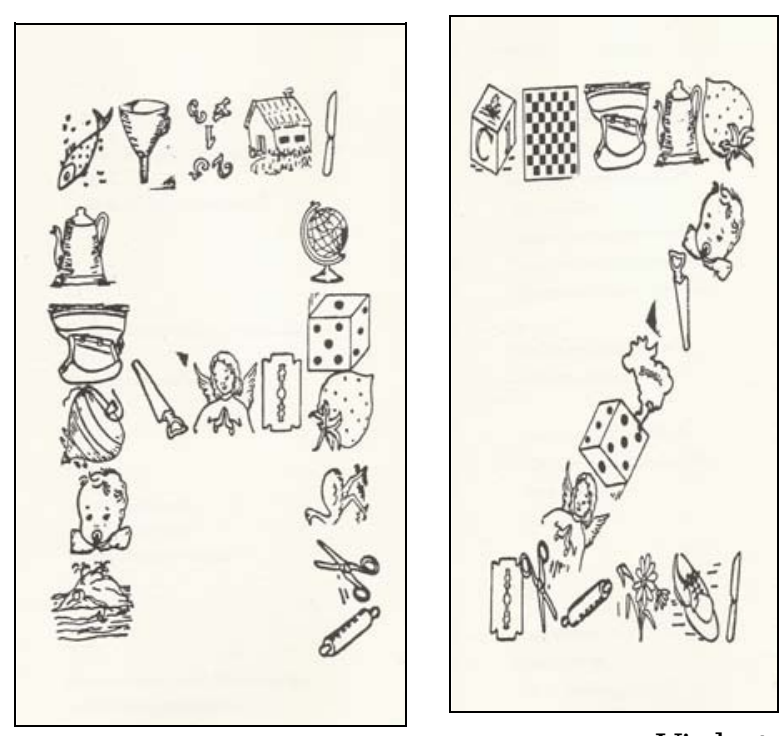

Vinhetas de Siron Franco em

Concerto a céu aberto para solos de ave.

Nas vinhetas de Siron Franco, vêem-se animais como gato, cachorro, peixe e ema, bem como objetos domésticos, como xícara, pires, faca. Há também um bebê, um pião, um sapato, um dado etc. Destaco o bule, pois ele foi pintado por um artista muito admirado por Barros que exalta seus azuis em Matéria de poesia:

Muita coisa se poderia fazer em favor da poesia

$[\ldots]$

j- Deixar os substantivos passarem anos no esterco, deitados de barriga, até que eles possam carrear para o poema um gosto de chão - como cabelos desfeitos no chão - ou como o bule de Braque áspero de ferrugem, mistura de azuis e ouro - um amarelo grosso de ouro da terra, carvão de folhas. [MP - 182].

O azul é, reiteradamente, destacado em O livro das ignorãças:

Se batesse um azul no horizonte seu olho entoasse. [LI - 23].

Há um azul em abuso de beleza. [LI - 39]. 
O azul me descortina para o dia. [LI - 67].

Nos fundos do quintal há um menino e suas latas Maravilhosas.

Seu olho exagera o azul. [LI - 75].

Para reverenciar os mutismos, muitas vezes, Van Gogh usava o azul. Em uma carta a seu irmão Theo, ele escreve: Continuo sempre à procura do azul. As figuras de camponeses, aqui, em regra geral, são azuis. No trigo maduro, ou destacando-se sobre as folhas secas de uma ala de faias, de forma que os matizes escalonados de azul-escuro e de azul-claro recobram vida e passam a expressarse opondo-se aos tons dourados ou castanhos-vermelhos; isto é muito bonito e desde o começo me impressionou. [Van Gogh, 133].

O amarelo está presente em "Noite estrelada" e nos vários girassóis pintados pelo artista. Em O livro das ignorãças, lê-se: Um girassol se apropriou de Deus: foi em Van Gogh. (LI - 15).

Em Face imóvel, lê-se: Hoje eu vi homens recebendo a guerra/ Recebendo o pranto como balas no peito/ $\mathrm{E}$ como a dor me abaixasse a cabeça/ Eu vi os girassóis de Van Gogh. [FI - 61].

Em Poesias, lê-se: Um peixe de azebre morrendo... morrendo em dezembro./ E a tarde exibindo os seus/ Girassóis, aos bois.

Parece que os holandeses girassóis de Van Gogh associam-se aos bois pantaneiros nesse "quadro", em que são associados elementos da natureza viva e da natureza morta, já que os peixes estão morrendo.

O silêncio nos quadros de Van Gogh é mencionado por Orlandi: $O$ silêncio não é diretamente observável e no entanto não é vazio, mesmo do ponto de vista da percepção: nós o sentimos "lá" ([...], no amarelo de Van Gogh, nas grandes extensões, nas pausas).

Barros, em Livro de pré-coisas, associa o amarelo ao silêncio do subtexto: A língua é uma tapagem. E tão subterrânea a instalação das palavras em meu canto como os silêncios conservados no amarelo.(LPC - 68). 
A capa de Beto Lima para o livro, publicada pela Editora Civilização Brasileira, também em 1993, tem fundo amarelo.

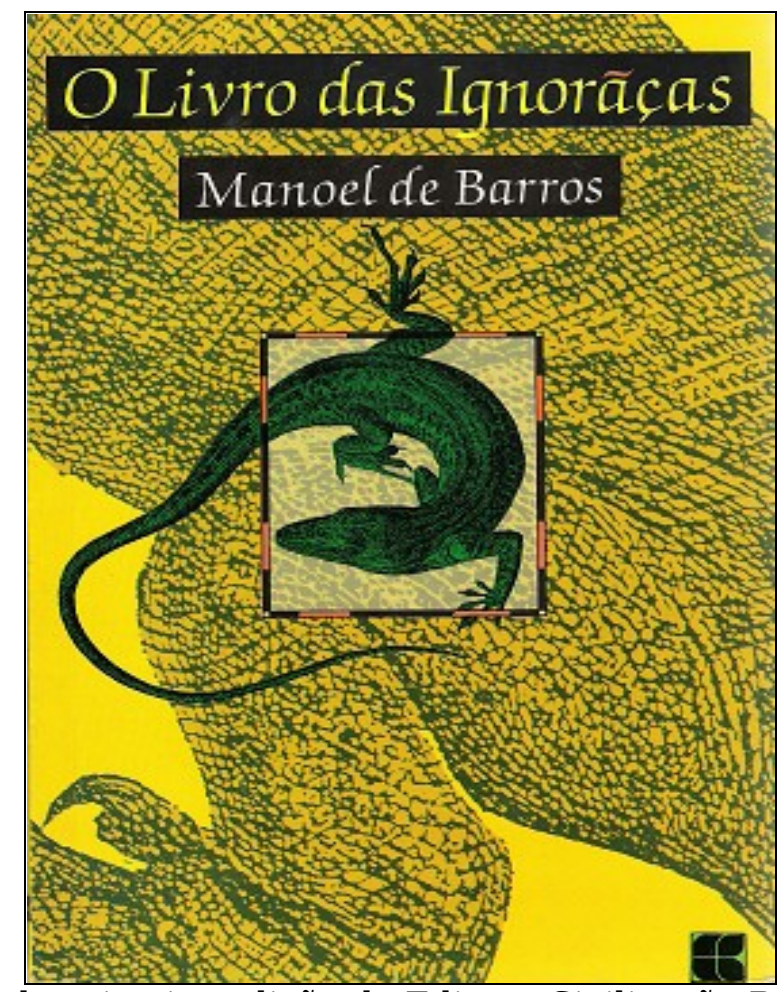

Capa da primeira edição da Editora Civilização Brasileira para O livro das ignorãças, de 1993.

O amarelo, para Goethe é a cor mais luminosa, e o azul estaria associado à sombra. O verde, que é a combinação dessas duas cores, exalta, pois, o claro e o escuro, estando no lagarto dessa capa de O livro das ignorãças bem como em alguns auto-retratos de Van Gogh.

Ziraldo criou uma imagem para o personagem Bernardo em $O$ fazedor de amanhecer, de Barros, inspirada em um dos muitos auto-retratos do pintor holandês. 


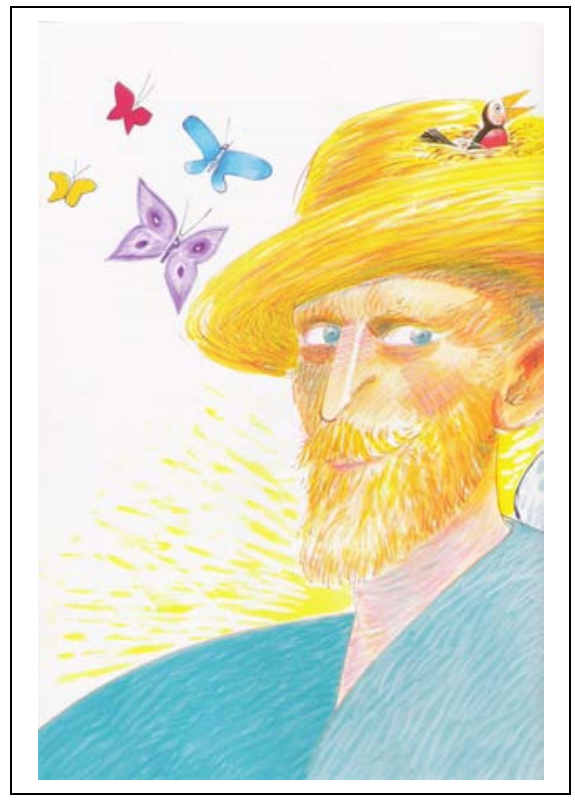

Ilustração de Ziraldo para $O$ fazedor de amanhecer, de Barros.

Van Gogh e seus azuis e amarelos aparecem em um dos episódios do filme "Sonhos", de Akira Kurosawa, que será comparado com Barros na próxima seção. 


\title{
NA QUIETEZ DOS SONHOS
}

\author{
A primeira visão foi uma flor \\ que me disse seu nome/ \\ Cravada no chão quente como o sol/ \\ Em fotos coloridas/ Paisagem onde \\ nada mais se distancia/ onde é bom \\ ver o mundo cada vez menor/ [...]. Haverá proteção \\ pra quem ainda pode ser livre/ \\ Na frente de tanta imagem que explode/ \\ Um minuto de silêncio é o melhor que se fazl \\ Num mundo tão pequeno \\ ("Proteção", \\ de Humberto Effe e Dé
}

\begin{abstract}
Estou atravessando um período de árvore./ O chão tem gula de meu olho por motivo que meu/ olho tem escórias de árvore./ O chão deseja meu olho vazado pra fazer parte do cisco que se acumula debaixo das árvores./ O chão tem gula de meu olho por motivo que meu/ olho possui um coisário de nadeiras./ O chão tem gula de meu olho pelo mesmo motivo/ que ele tem gula por pregos por latas por folhas./ A gula do chão vai comer o meu olho./ No meu morrer tem uma dor de árvore. [LI - 99].
\end{abstract}

Estou atravessando um período de árvore. A idéia contida nesse primeiro verso é desenvolvida em outro poema:

Para entrar em estado de árvore é preciso partir del um torpor animal de lagarto às três horas da tarde,/ no mês de agosto./ Em dois anos a inércia e o mato vão crescer em nossa boca./ Sofreremos alguma decomposição lírica até o mato/ sair na voz./ Hoje eu desenho o cheiro das árvores. [LI - 17].

Assim, da árvore, o sujeito poético incorpora em si seu silêncio: Em dois anos a inércia e o mato vão crescer em nossa boca. Depois, o homem não mais usará palavras e sim uma expressão verde: Sofreremos alguma decomposição lírica até o mato/ sair na voz. 
A idéia de indistinção entre os seres e os vegetais está presente em outros trechos de $O$ livro das ignorãças, como neste em que o pássaro traz para dentro de si características arbóreas: Qualquer defeito vegetal de um pássaro pode modificar os seus gorjeios. [LI-19].

Nery Nice Biancalana Reiner observa que a árvore serve para simbolizar $o$ aspecto cíclico da evolução cósmica: morte e regeneração, despindo-se das folhas e voltando a vesvamente, verdes e brilhantes, quando chega a primavera. [...]. Permite a comunicação dos três níveis cósmicos: o subterrâneo, através das raízes; o terrestre, através do tronco e dos galhos inferiores; o celeste, por meio de seus galhos superiores, de sua copa. Répteis rastejam por entre suas raízes; animais passeiam pelos seus troncos; pássaros voam por entre suas ramagens. [Rainer, 2006, 168].

A estudiosa faz as seguintes observações sobre o poema em análise:

No primeiro verso, o leitor fica surpreso com o sujeito lírico de "estar atravessando um período de árvore". Não faz parte de nossas experiências humanas "atravessar um período de árvores". [...]. Em seguida há outra afirmação estranha: o chão quer comer o olho do sujeito, porque aquele tem resíduos, ciscos de árvore e possui um coisário de nadeiras. É necessário explicar que os vocábulos coisário e nadeiras não são dicionarizados. São neologismos criados pelo poeta. Poderíamos traduzir coisário = conjunto, uma quantidade de coisas e nadeiras = conjunto ou quantidade de "nadas", coisa nenhuma. [Reiner, 2006, p. 189].

Tais nadeiras podem aproximar Barros de Akira Kurosawa. No Budismo é preciso aproximar-se do nada, para que o silêncio torne-se viável, ou seja, é preciso esvaziar a mente para propiciar a meditação, o que faz o homem sentirse integrado a tudo.

No ano de lançamento de O livro das ignorãças, 1993, Barros em entrevista à Folha de São Paulo, afirmou: Eu prezo muito essa atitude zen de buscar uma comunhão total com as coisas. Ficar diante de um quadro até que o quadro veja você. [Barros, in: Couto,1993, p. 9].

No filme "Sonhos", que pode ser considerado um auto-retrato onírico de 
Akira Kurosawa, um homem com chapéu de tecido, parecido com aquele que o diretor usava quando jovem, mira quadros de Van Gogh e integra-se a suas imagens.

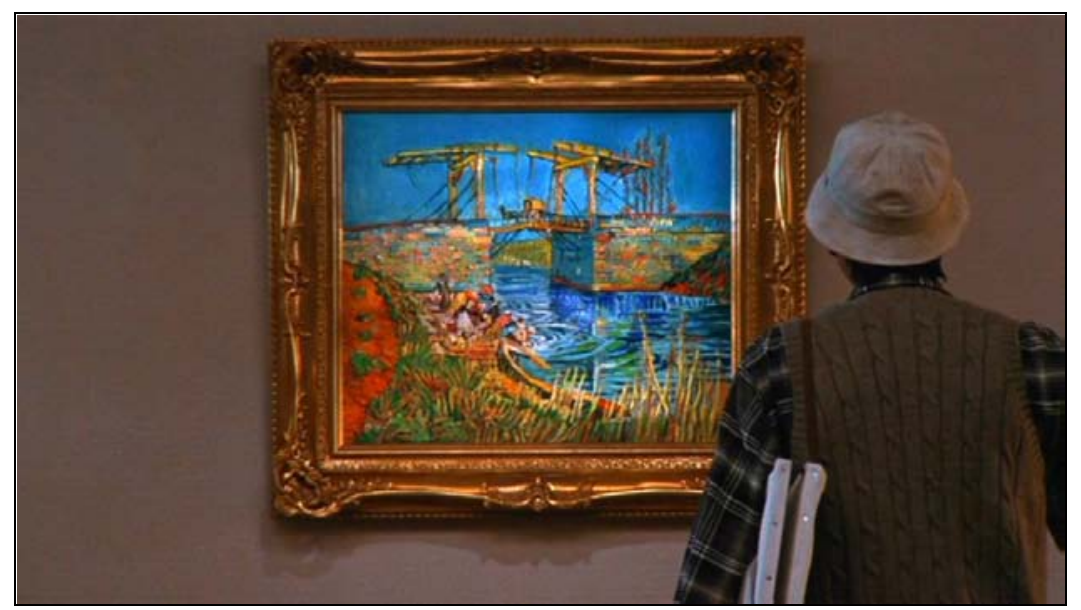

Fotograma de "Sonhos", de Akira Kurosawa

Ele olha um auto-retrato do pintor holandês, o "Noite estrelada", uma natureza-morta com girassóis, o "Corvos sobre campos de trigo" e pára diante de "A ponte em Langlois".

Em seguida, Akira entra no quadro e pergunta às lavadeiras onde poderia encontrar Van Gogh. Elas apontam para a direção em que o pintor costumava ficar e uma delas diz que é preciso tomar cuidado, pois ele tinha acabado de sair do hospício.

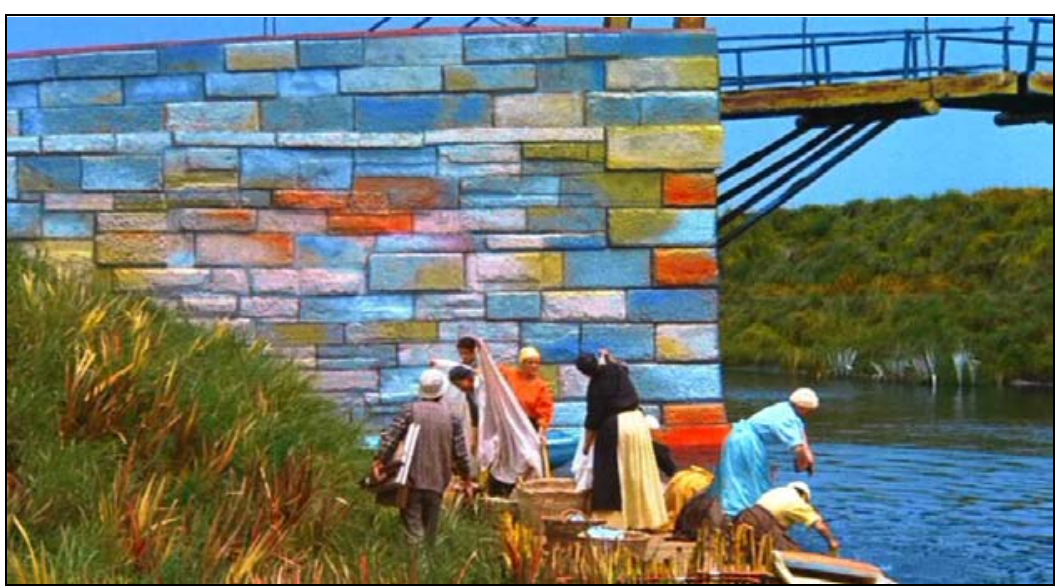

Fotograma de Sonhos, de "Akira Kurosawa".

Kurosawa encontra com Van Gogh e conversam um pouco. O pintor diz que 
quando vê uma paisagem bela ele quer devorá-la. Afirma que lhe resta pouco tempo e deve pintar como uma locomotiva. Akira pergunta se ele está machucado, apontando para a faixa em sua cabeça. Van Gogh responde que no dia anterior, ao tentar fazer seu auto-retrato, não gostou de como sua orelha ficou pintada, por isso eliminou-a.

Em seguida, sai, dizendo que o sol o impele a pintar. Kurosawa se vira para o sol, para olhá-lo e depois percebe que Van Gogh não está mais à vista. Começa, então, a procurá-lo e as paisagens pelas quais passa são os quadros do pintor.

Em sua autobiografia, o diretor afirma: Depois de ver uma monografia de Cézanne, eu iria sair caminhando e as casas, ruas e árvores - tudo - parecia uma pintura de Cézanne. O mesmo ocorreria quando eu olhei um livro de pinturas do Van Gogh... Elas mudaram a forma que o mundo real olhava para mim. Parecia completamente diferente do mundo que eu usualmente via com meus próprios olhos. [Kurosawa, apud: Richie, 1996, p.222].

Ao final do episódio de "Sonhos", Akira vê Van Gogh sumir no topo de um morro; então, vários corvos aparecem. A última seqüência mostra o cineasta vendo o quadro "Corvos sobre campos de trigo", do pintor holandês.

O mutismo do olhar dá a base para uma outra colorida história sonhada, só que com proporções catastróficas. Dois homens e uma mulher com dois filhos assistem às explosões de um vulcão e vêem nuvens coloridas invadirem tudo. Um dos homens afirma que é responsável por aquilo e explica: As nuvens. A vermelha é plutônio 239. Um décimo milionésimo de grama causa câncer. A amarela é estrôncio 90. Entra em você e causa leucemia. A roxa é césio 137. Afeta a reprodução. Produz mutações. Faz nascer monstruosidades. [...]. A radioatividade era invisível. Por causa do perigo, eles a coloriram. Mas isso só permite que você saiba qual o tipo vai matá-lo. É o cartão de visita da morte. 


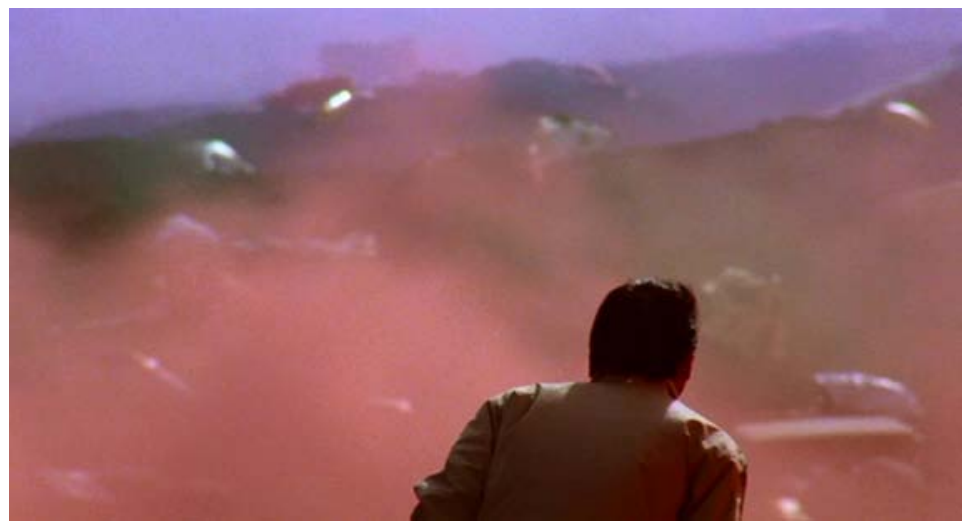

Fotograma de "Sonhos".

A crítica a usinas e bombas nucleares é recorrente nos livros de Barros e nos filmes de Kurosawa. Em "Rapsódia em agosto", do diretor japonês, um grupo de adolescentes visita sua avó, em Nagasaki, que perdeu seu esposo no célebre e horrendo borbardeio.

Um personagem que testemunhou esse horror viu na fumaça formar-se um terrível olho.
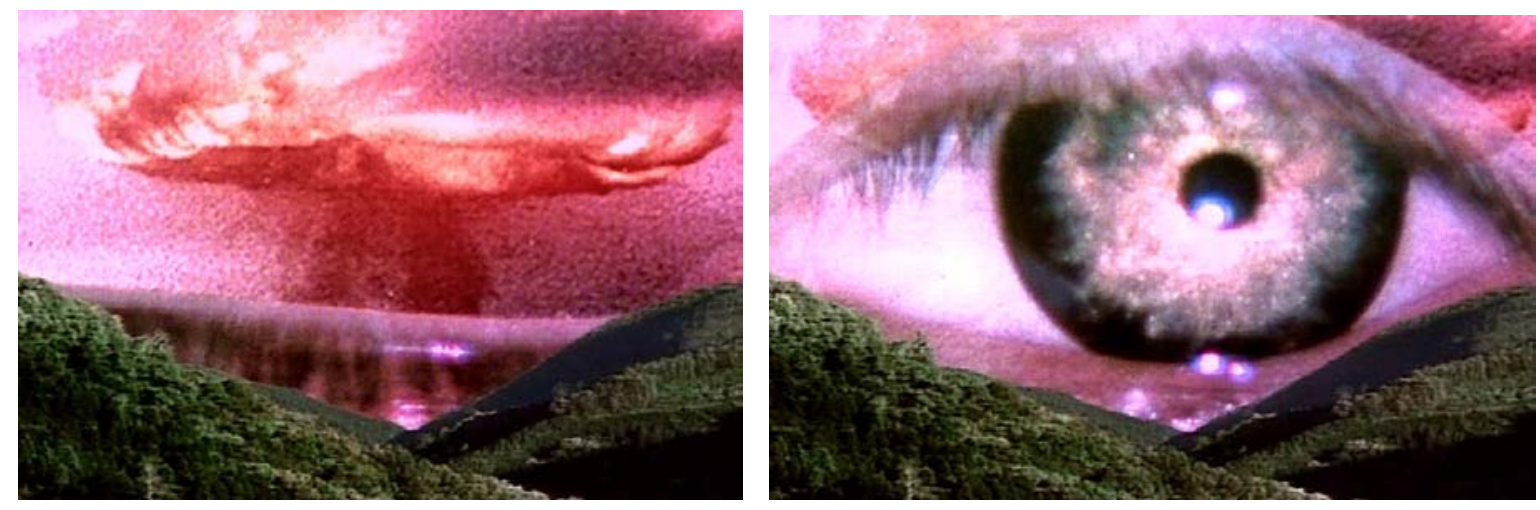

Fotogramas de "Raspsódia em Agosto"

No poema em análise, a palavra olho repete-se sete vezes:

Estou atravessando um período de árvore./ O chão tem gula de meu olho por motivo que meu/ olho tem escórias de árvore./ O chão deseja meu olho vazado pra fazer parte do cisco que se acumula debaixo das árvores./ $O$ chão tem gula de meu olho por motivo que meu/ olho possui um coisário de nadeiras./ $O$ chão tem gula de meu olho pelo mesmo motivo/ que 
ele tem gula por pregos por latas por folhas./ A gula do chão vai comer o meu olho./ No meu morrer tem uma dor de árvore. [LI - 99].

Tanto em Barros quanto em Kurosawa o olhar é elemento fundamental. O primeiro episódio de "Sonhos" mostra a história de um menino, que vê, atrás de uma grande árvore, as raposas se casarem (são vários atores, com maquiagem que lembra esses animais, que dançam no meio da floresta).

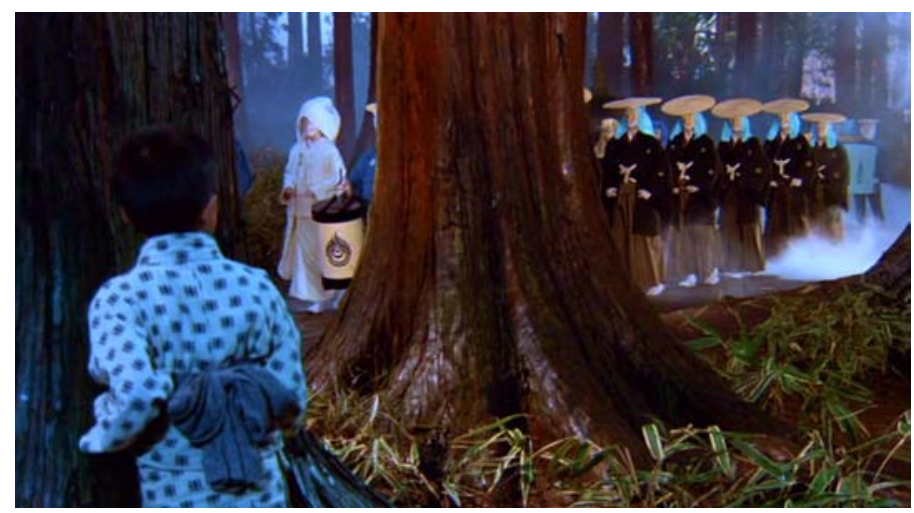

O ato é infracional, pois sua mãe havia dito que isso não poderia ser visto; o menino, cuja presença acaba sendo notada pelas raposas, volta para casa e sua mãe o espera, dizendo que uma raposa furiosa o procurava, dizendo que ele devia se matar por ver o ato interdito ou então devia procurá-la para pedir desculpa, ao fim do arco-íris. Mas adiantava: raposas são difíceis de perdoar. $\mathrm{O}$ final em aberto desse episódio, como os dos contos de Tchékhov, mostra o menino, em meio a flores multicoloridas, olhando o arco-íris e se dirigindo ao seu final.
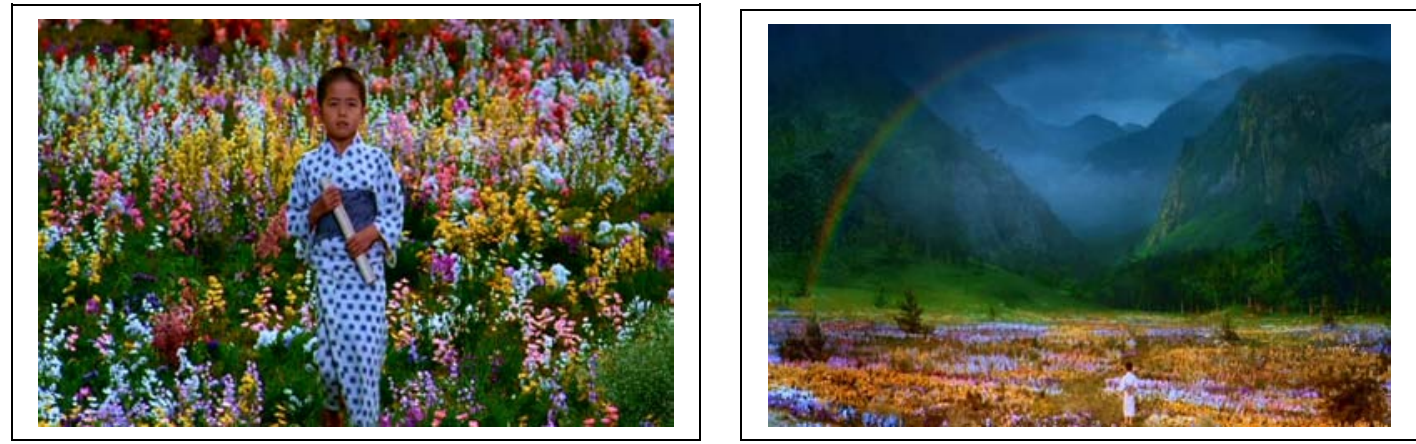
Akira Kurosawa afirmou que seu filme realmente faz jus ao título: são sonhos que teve ao longo de sua vida. Se sonho e invenção são um pouco parentes já que seriam imagens que a alma viu, então esse episódio do diretor se parece com um poema de Tratado geral das grandezas do ínfimo. Nele, um menino também adentra um verde espaço (não a floresta japonesa, mas o matagal do Pantanal brasileiro), depara-se com a presença animal (não as raposas e sim uma onça) depois se encontra com sua mãe. A diferença, além da espacial e dos animais em questão, é que no filme isso é sonhado, enquanto no poema isso é inventado:

\section{INFANTIL}

O menino ia ao mato/ E a onça comeu ele./ Depois o caminhão passou por dentro do corpo do/ menino/ E ele foi contar para a mãe./ A mãe disse: Mas se a onça comeu você, como é quel o caminhão passou por dentro do seu corpo?/ é que o caminhão só passou renteando meu corpo/ E eu desviei depressa./ Olha, mãe, eu só queria inventar uma poesia./ Eu não preciso de fazer razão. [TGGI - 29].

O chão tem gula de meu olho por motivo que meu/ olho tem escórias de árvore./ O chão deseja meu olho vazado pra fazer parte do cisco que se acumula debaixo das árvores. A idéia de morte permeia esses versos, do poema em análise, já que o sujeito poético antevê o que ocorrerá com seus olhos: serão devorados pela terra e incorporado ao cisco que se acumula debaixo das árvores. Homem e a terra tornar-se-ão um amálgama em contato com as raízes da árvore.

No meu morrer tem uma dor de árvore. Um homem com uma dor de árvore, ou melhor, um menino com uma dor de árvore é visto em um episódio do filme "Sonhos", de Akira Kurosawa. Essa criança vê seis meninas num grupo em que está também a sua irmã. Vai à cozinha e traz algo para elas beberem e comerem e se dá conta que falta uma.

Sua irmã diz que ele está delirando e volta a conversar com as colegas. O menino revê a garota dentro e fora da casa; ele a segue. 
Ela vai para o lugar em que estavam vários pessegueiros, que foram cortados. Os espíritos desses pessegueiros estão lá e o "líder" deles culpa o menino pela sua extinção, mas um outro espírito afirma que ele não só foi contrário ao desmatamento como tentou impedi-lo. Então o líder afirma que ele queria os pêssegos e o menino diz que pêssegos podem ser comprados e pergunta: quem pode comprar um pessegueiro em flor?

Assim, os espíritos dizem que ele pode vê-los pela última vez, tocam, dançam enquanto essas imagens e as dos pessegueiros em flor se alternam para o olhar do menino. Terminada a música e a dança, eles somem do campo da sua visão.
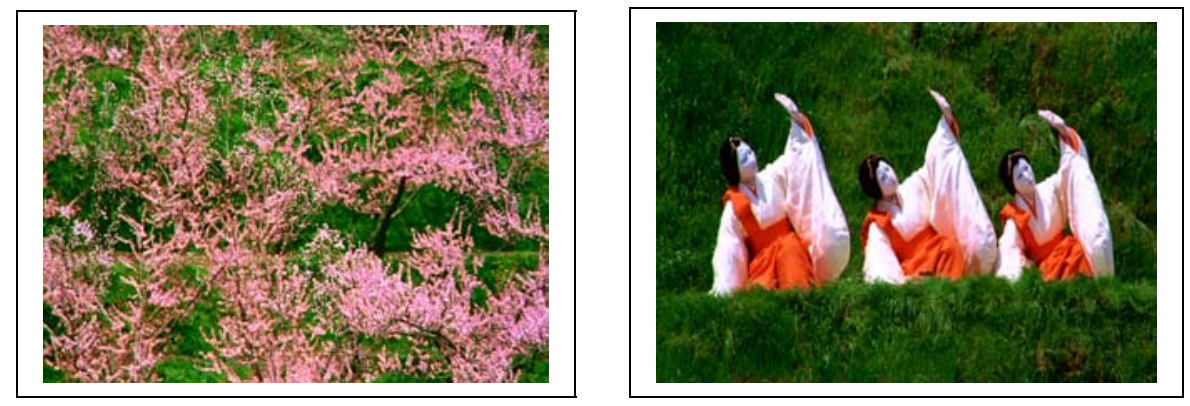

Fotogramas de "Sonhos".

O mutismo do olhar testemunha os silêncios de uma quieta dança e de uma música sem palavras e um êxtase pode ser notado no eloqüente e mudo rosto da criança.

Crianças, seus silêncios, suas visões recebem um zoom de Kurosawa e de Barros. Neste trecho, o sujeito poético de um outro poema de O livro das ignorãças emudece para ouvir os infantes:

No descomeço era o verbo.

Só depois é que veio o delírio do verbo.

O delírio do verbo estava no começo, lá onde a

Criança diz: Eu escuto a cor dos passarinhos.

A criança não sae que o verbo escutar não funciona

Para cor, mas para som.

Então se a criança muda a função de um verbo, ele

Delira.

E pois.

Em poesia que é voz de poeta, que á voz de fazer

Nascimentos - 
O verbo tem que pegar delírio. [LI - 15].

As crianças estão mais próximas do inominável: As coisas que não têm nome são mais pronunciadas por crianças [LI - 13].

Em outro trecho de $O$ livro das ignorãças, questiona-se um nome pomposo e artificial que não tem nenhuma relação com o ente nomeado que é simples e espontâneo:

O rio que fazia uma volta atrás de nossa casa/ era imagem de um vidro mole que fazia uma volta atrás de casa./ Passou um homem depois e disse: essa volta que o rio faz por trás de sua casa se chama enseada./ Acho que o nome empobreceu a imagem. [LI - 25].

Aparecem também nessa obra seres com dois nomes: um oficial e um apelido que os outros escolhem. Aqui ocorrem a recusa e o questionamento populares ao nome registrado e busca-se um outro mais adequado:

Eu hei de nome Apuleio./ Esse cujo eu ganhei por sacramentos por sacramentos./ Os nomes já vêm com unha? / Meu vulgo é Seo Adejunto - de dantes caboadjunto) por servimentos em quartéis/ Não tenho proporções para apuleios./ Meu asno não é de ouro./ Ninguém que tenha natureza de pessoa pode esconder/ as natências.[LI -35].

Importante observar, inclusive, que o termo erudito adjunto, transforma-se em adejunto, na forma popular, com o acréscimo da vogal $e$. Acréscimos e decréscimos de vogais feitos pelo povo em palavras oficiais são práticas muito comuns. O nome Apuleio, que lembra o autor latino de $O$ asno de ouro, não é aceito já que o asno desse canoeiro pobre do Pantanal não é de ouro.

Em outro trecho da obra de Barros, lê-se: As coisas que não têm nome são mais pronunciadas por crianças. [LI - 13].

O boiadeiro Malafincado gostava de desnomear, assim como os sete samurais, do célebre filme de Kurosawa. Um deles pede aos outros que o desnomeiem, ou seja, ofereçam a ele um nome diverso do que tinha:

- Qual seu verdadeiro nome?

- Não me lembro. Me dê um bom nome. 
- Kikuchiyo. Isso o transforma.

No último episódio de "Sonhos", um ancião vê chegar perto dele um jovem, que pergunta: Qual o nome dessa aldeia? A resposta é: Não tem nome. Nós chamamos apenas de "a aldeia". Algumas pessoas a chama de Aldeia dos Moinhos de Água.

Nessa aldeia sem nome, o óbito é motivo de alegria e um cortejo fúnebre ocorre com música e muitas cores.

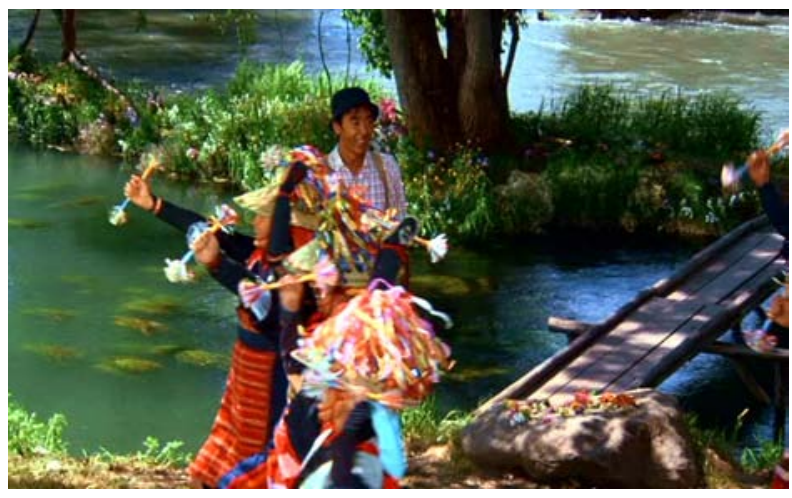

Fotograma de "Sonhos".

Essa situação reflete uma visão budista em que a morte é vista como motivo de contentamento já que se chegou ao final de uma etapa, que por sua vez pertence a um contexto mais amplo: o das reencarnações. Um velório com direito a "comes e bebes" é visto no filme "Viver", de Kurosawa.

O silêncio está presente em vários filmes de Kurosawa. Em “Rapsódia em agosto", a viúva de um homem morto no borbardeio de Nagasaki recebe, costumeiramente, a visita de uma mulher com a mesma realidade. Elas passam horas em pleno emudecimento. 


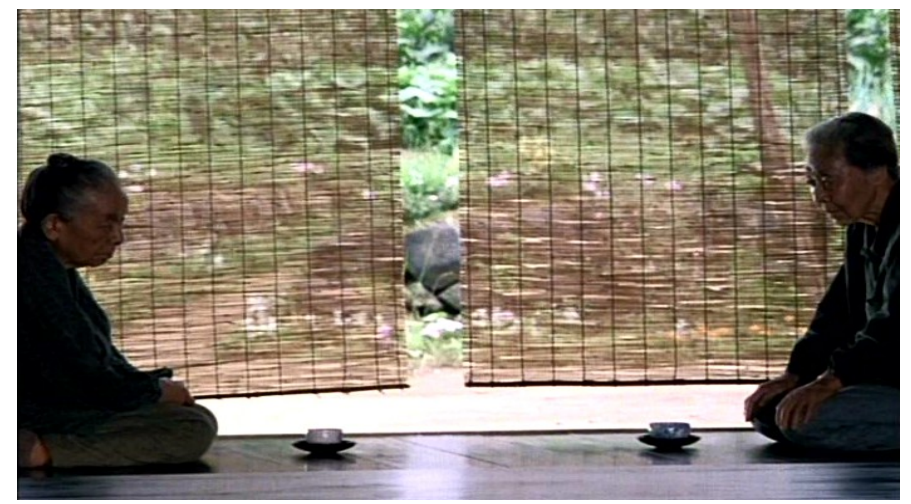

Visita silenciosa, em "Rapsódia em agosto” .

A dor sentida em silêncio aparece também no filme "O barba ruiva".

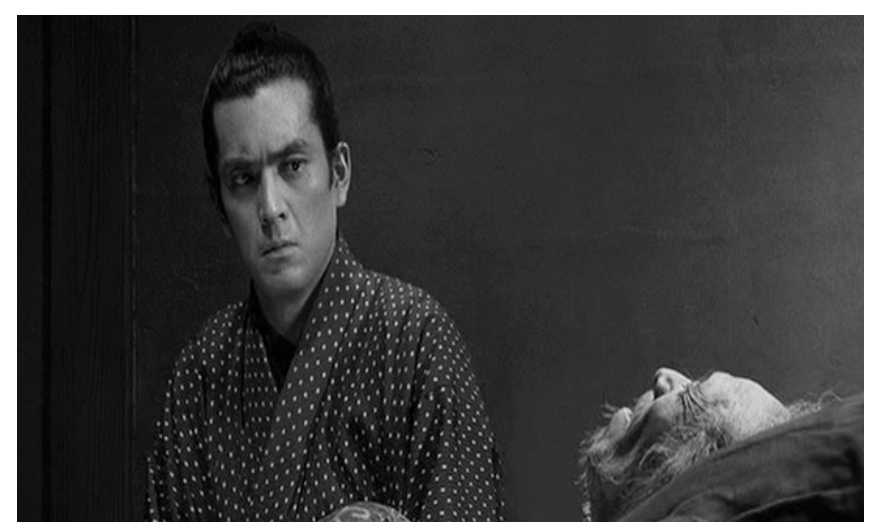

Fotograma de "O barba ruiva".

Em “Dodes'ka-den”, são mostrados vários moradores de uma favela japonesa, dos quais destacam-se também um cego, que ao longo de toda a película não pronuncia uma só palavra, e Katsuko, uma menina que é explorada e estuprada pelo esposo da sua tia, mantendo-se também muda em quase toda a história, sendo monossilábica quase ao final dela.
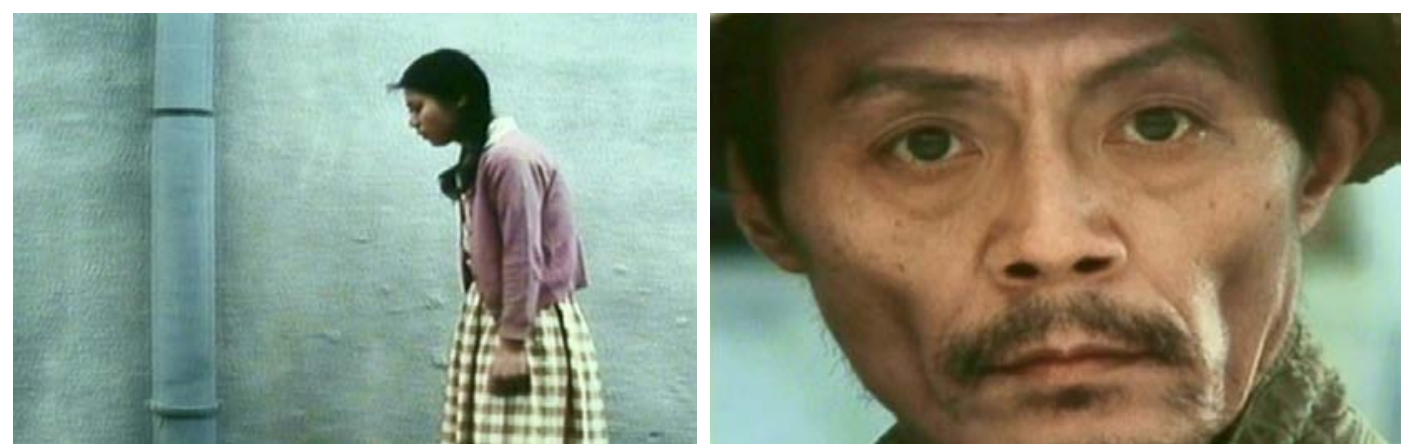

A silenciosa, e às vezes, monossilábica Katsuko e o sempre mudo personagem cego de "Dodes'ka-den". 
Esse é o primeiro filme colorido de Kurosawa, que foi comparado com a pintura de Mondrian e de Kandinski. Há um homem que mora na carcaça de um carro e constrói visualmente, a cada dia, a casa na qual pretende morar com seu filho.

Bernardo, em Tratado geral das grandezas do ínfimo, via e ouvia inexistências; ele é irmão de um personagem de "Dodes'ka-den": Rokuchan, que mira e escuta os barulhos de um trem que ele supõe dirigir todos os dias. Sua mãe coleciona os desenhos que seu filho fez quando criança, com esse meio de transporte.

Os favelados japoneses são também retratados em "Ralé", adaptação do texto de Gorki. Há outra adaptação de Kurosawa de um escritor russos: Dersu Uzala, de Arseniev. A figura do caçador, que está presente no poema analisado na seção anterior [Caçador, nos barrancos, de rãs entardecidas,/ Sombra-Boa entardece] aparece nesse filme, de 1975, homônimo ao livro,.

A película foi rodada na Rússia, com colaboração, no roteiro, de Yuri Nagibin e mostra a história de um gold, uma espécie de índio, da Sibéria oriental, que foi responsável por uma verdadeira revolução no ver e no ouvir do capitão Arseniev e seus soldados.

Dersu, como Sombra-Boa, comunica-se com a natureza: em uma cena, ele canta e quando, ciclicamente, emudece, um pássaro responde.

Arseniev muito silencia para ouvir Dersu. Depois de acharem uma cabana abandonada, o gold pede ao militar que lhe dê sal, fósforo e arroz, para que alguém que chegue àquele lugar não morra de frio ou fome.

Isso comove o militar: Esse gold me encheu de admiração. Ele tinha uma perspicácia surpreendente, conseguindo viver toda a sua vida na floresta. Apesar de tudo ele tinha uma alma bonita. Ele proveu as necessidades de uma pessoa que não conhecia e provavelmente jamais a veria.

Em outra cena, Dersu zanga-se com um soldado: Por que joga carne no fogo? Jogar carne no fogo é desperdício. Amanhã nós vamos, outros companheiros vem aqui, vêem a carne e comem. 
Um outro soldado pergunta: Quem viria aqui? A resposta é: [...]. Texugo vem aqui. Marta vem aqui. Corvo vem aqui. Rato vem aqui. Todos os tipos de companheiros da floresta.

Sobre esse filme, Kurosawa declarou: $O$ relacionamento entre seres humanos e natureza vai de mal a pior... eu queria que as pessoas do mundo inteiro ficassem conhecendo esse personagem soviético-asiático que vivia em harmonia com a natureza... creio que as pessoas deveriam ser mais humildes, pois somos parte dela e devemos nos harmonizar com ela. Se a natureza for destruída, os seres humanos também serão. Portanto, podemos aprender muito com Dersu. [Kurosawa, apud: Richie, 1984, p. 201].

Além de mostrar os caminhos das florestas e geleiras, Dersu ensina ao capitão e a seus soldados como serem mais solidários com outros homens e a ver animais, vegetais, água e vento como irmãos, como seus iguais.

Dersu é muito parecido, pois, com os bugres manoelinos, que já estão na primeira obra do poeta. Em O livro das ignorãças, o sujeito poético denomina-se como bugre:

Descobri aos 13 anos que o que me dava prazer nas leituras não era a beleza das frases, mas a doença delas

Comuniquei ao Padre Ezequiel, um meu Preceptor,

Esse gosto esquisito.

Eu penava que fosse um sujeito escaleno.

- Gostar de fazer defeitos na frase é muito

Saudável, o Padre me disse.

Ele fez um limpamento em meus receios.

O Padre falou ainda: Manoel, isso não é doença,

Pode muito que você carregue para o resto da

Vida um certo gosto por nadas...

E se riu.

Você não é de bugre? - ele continuou.

Que sim, eu respondi.

Veja que bugre só pega por desvios, não anda em

Estradas -

Pois é nos desvios que encontra as melhores surpresas e os ariticuns maduros.

Há que apenas saber errar bem o seu idioma.

Esse Padre Ezequiel foi o meu primeiro professor de

agramática. [LI - 87]. 
Aurora Fornoni Bernardini faz o seguinte comentário: etimologicamente, essa palavra [bugre] teria entrado em nosso léxico através do termo francês bougre - que, por sua vez, deriva da palavra "búlgaro", que era sinônimo de nãocristão, de infiel, de pessoa sexualmente pervertida, enfim. Significava alguém excluído e também temido pelo seu potencial transgressor. Para Manoel de Barros, o bugre é também um ser transgressor, na medida em que não participa ativamente da vida socioeconômica do Pantanal, mas perambula livre pelos campos, convivendo "promiscuamente" com as plantas, bichos, rochas etc. $O$ bugre pode ser definido como um louco, um andarilho, como um índio sem tribo, que ficou sozinho na terra mas reencontrou o mundo mítico, unindo o fim (a decadência) ao começo, à época criativa. [Bernardini, s. d. p. 21].

Para se atingir um falar bugre, cheio de transfazimentos, os sujeitos poéticos manoelinos põem-se a escavar na linguagem, para encontrar os fósseis lingüísticos mais primitivos, como em Memórias inventadas: a infância:

Eu tinha vontade de fazer como os dois homens que vi sentados na terra escovando osso. No começo achei que aqueles homens não batiam bem. Porque ficavam sentados o dia inteiro escovando osso. Depois aprendi que aqueles homens eram arqueólogos. E que eles queriam encontrar nos ossos vestígios de antigas civilizações que estariam enterrados por séculos naquele chão. Logo pensei de escovar palavras. Porque eu havia lido em algum lugar que as palavras eram conchas de clamores antigos. Eu queria ir atrás dos clamores antigos que estariam guardados dentro das palavras. Eu já sabia também que as palavras possuem no corpo muitas oralidades remontadas. Eu queria então escovar as palavras para escutar o primeiro esgar de cada uma. Para escutar os primeiros sons, mesmo que ainda bígrafos. [MII, sem paginação].

Ao poeta, na obra manoelina, cabe buscar os vestígios de linguagens arcaicas, para que a palavra atinja sua condição primal, mais próxima do silêncio inaugural. Daí, a proximidade desses escritos com o mito e com o universo indígena.

O índio teria uma linguagem mais próxima da desarticulação primeva, pois 
no seu contato intenso com a natureza, ele faria reverberar, no seu linguajar, o mutismo das pedras e os cantos sem palavras dos pássaros:

Contenho vocação pra não saber línguas cultas. Sou capaz de entender as abelhas do que alemão. Eu domino os instintos primitivos./ A única língua que estudei com força foi a portuguesa./ Estudei-a com força para poder errá-la ao dente./ A língua dos índios Guatós é murmura: é como se ao dentro de suas palavras corresse um rio entre pedras./ A língua dos Guaranis é gárrula: para eles é muito mais importante o rumor das palavras do que o sentido que elas tenham./ Usam trinados até na dor./ Na língua dos Guanás há sempre uma sombra do charco em que vivem./ Mas é língua matinal./ Há nos seus termos réstias de um sol infantil./Entendo ainda o idioma inconversável das pedras./ É aquele idioma que melhor abrange o silêncio das palavras./ Sei também a linguagem dos pássaros -é só cantar. [EF].

Nesse poema, Manoel mostra o resultado de sua vivência com índios do Peru, da Bolívia e do Brasil, notando, como se viu, as peculiaridades lingüísticas de cada tribo. Em $O$ livro das ignorãças, há também um relato lírico sobre sua convivência com os indígenas bolivianos e peruanos:

De 1940 a 1946 vivi em lugares decadentes onde o mato e a fome tomavam conta das casas, dos seus loucos, de suas crianças e de seus bêbados.

Ali me anonimei de árvore.

Me arrastei por beiradas de muros cariados desde

Puerto Suarez, Chiquito, Oruros e Santa Cruz de La Sierra, na Bolívia.

Depois em Barranco, Tango Maria (onde conheci o poeta Cesar Vallejo), Orellan e Mocomonco - no Peru.

Achava que a partir de ser inseto o homem poderia entender melhor a metafísica.

Eu precisava de ficar pregado nas coisas vegetalmente $e$ achar o que não procurava.

Naqueles relentos de pedra e lagartos, gostava de conversar com idiotas de estrada e maluquinhos de mosca

Caminhei sobre grotas e lajes de urubus.

Vi outonos mantidos por cigarras.

Vi lamas fascinando borboletas.

E aquelas permanências nos relentos faziam-me alcançar os deslimites do Ser. 
Meu verbo adquiriu espessura de gosma.

Fui adotado em lodo.

Já se viam vestígios de mim nos lagartos.

Todas as minhas palavras já estavam consagradas de pedras.

Dobravam-se lírios para os meus tropos.

Penso que essa viagem me socorreu a pássaros.

Não era mais a denúncia das palavras que me importava mas a parte selvagem delas, os seus refolhos, as suas entraduras.

Foi então que comecei a lecionar andorinhas.

Os bugres estão mais próximos do grau zero de uma palavra, que é buscado em O livro das ignorãças:

Minha voz inaugura os sussurros. [LI - 63].

A idéia dos índios de que todas as coisas da natureza têm alma está presente em vários escritos manoelinos e também em $O$ livro das ignorãças: Depois encontramos com a alma da chuva que vinha do lado da Bolívia - e demos no pé. (Rogaciano era índio Guató e me contou essa cosmologia.) [LI - 95].

O panteísmo indígena está presente em Cantigas por um passarinho à toa:

Quando a parede da tarde ruiu/ o homem falou:/ Hoje Ele chove!/ E Deus choveu na roça do homem./ E o homem agradeceu aquela graça como quando o azul se abre para nós.

Assim, Deus/Tupã está na chuva e se revela em toda a materialidade do mundo, como se vê em Memórias inventadas: a infância:

Cipriano falou:

Mais alto do que eu só Deus e os passarinhos. A dúvida era saber se Deus também avoava ou se Ele está em toda parte como a mãe ensinava. Cipriano era um indiozinho guató que aparecia no quintal, nosso amigo. [...]. Outro dia a gente destampamos a cabeça de Cipriano. Lá dentro só tinha árvore árvore árvore nenhuma idéia sequer. Falaram que ele tinha predominâncias vegetais do que platônicas. Isso era.

A idéia platônica de que o nosso mundo é uma cópia mal feita de um 
mundo superior não se aplica ao pensamento do índio Cipriano já que, para ele, a superioridade está cravada na concretude das coisas do chão.

Um elemento fundamental na mística indígena é a crença de que não há hierarquia entre os reinos animal, mineral, vegetal e hominal. Talvez por isso Sombra-Boa ouve e entende as conversas entre as gaivotas.

Como os bugres manoelinos, Dersu é bastante econômico em sua fala e muitas vezes a usa para pedir silêncio. Na noite em que conhece Arseniev e seus soldados, ele afirma: Hei, você faz muito barulho. Essas palavras que Olentiev, um dos séqüitos do capitão, pensa que se dirigem a ele são, na verdade, para um graveto, que emitia sonoros estalos na fogueira.

"Dersu Uzala" é filme que explora bem as cores. O azul e o amarelo aparecem em algumas cenas.
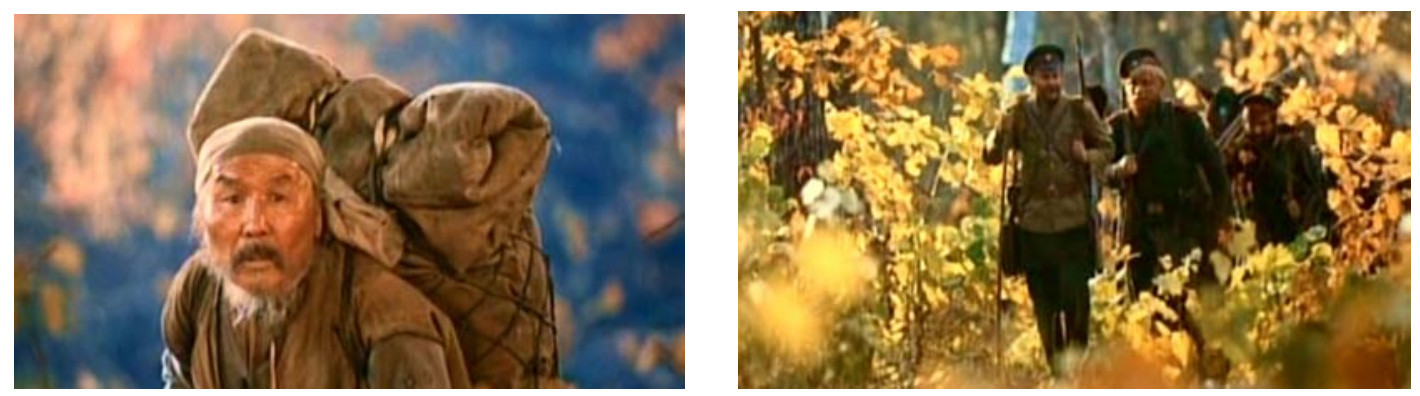

Fotogramas de "Dersu Uzala”.

Outras cores aparecem no filme como o vermelho, quando Dersu, Arseniev e mais dois soldados caminham no gelo sob o sol da meia-noite.

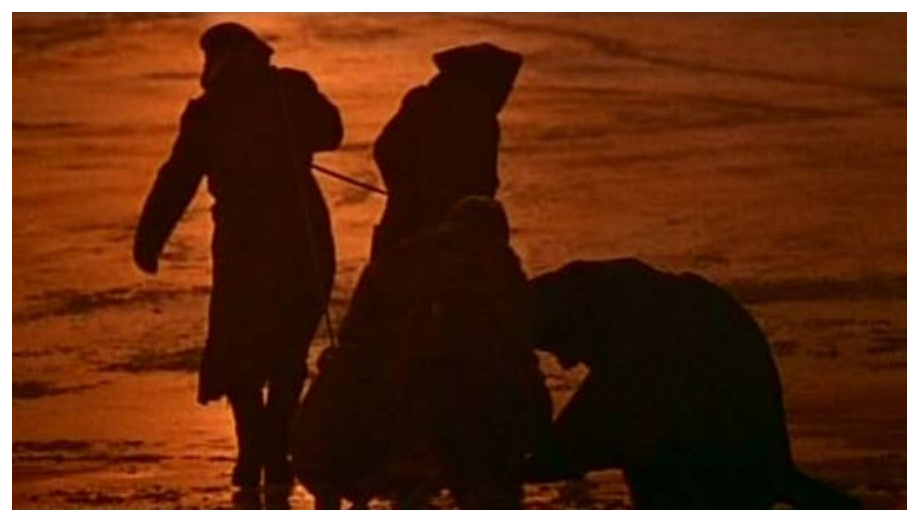

Fotograma de "Dersu Uzala".

O vermelho, o amarelo, e o azul são muito usados pelo Akira pintor, que deu forma a cenas e personagens na liguagem da arte pictórica. Essas três cores 
resultam no marrom, que foi usado nesse quadro para representar a terra, na pintura do diretor para "Ran".

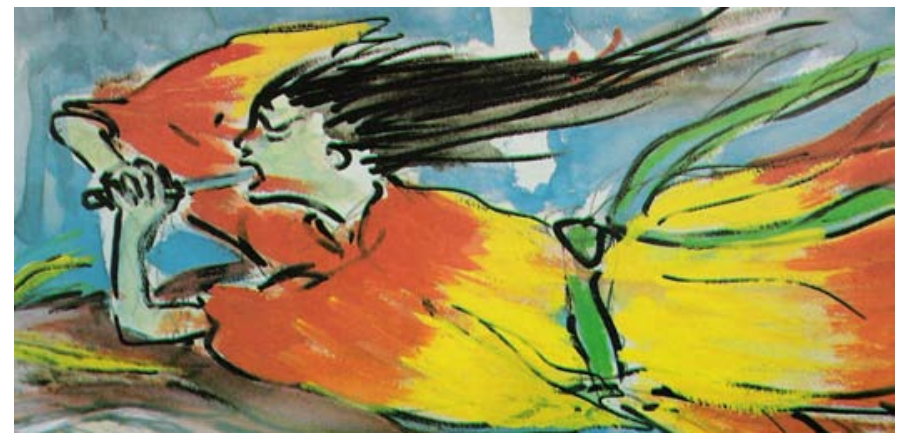

Pintura de Kurosawa para seu filme "Ran”.

José Mindlin usou o marron, na capa da sua edição de O livro das ignorãças, em 1993.Capa da edição de José Mindlin para O livro das ignorãças.

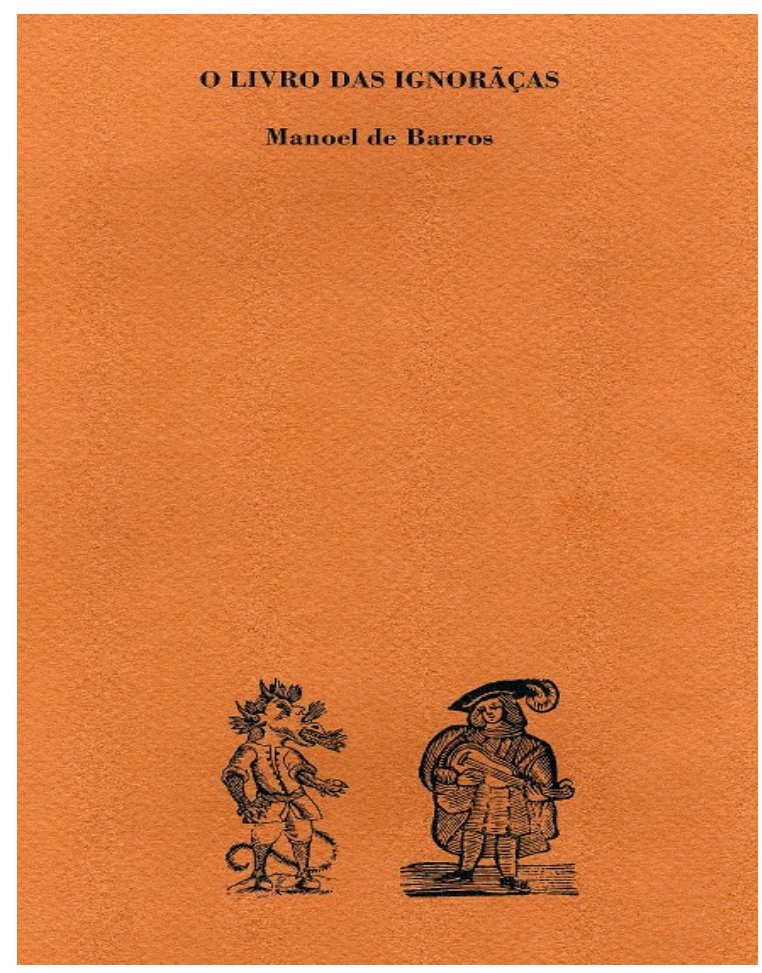

Capa da edição de José Mindlin de O livro das ignorãças.

O gosto de Barros pela cultura popular foi notado pelo célebre editor e colecionador de livros, pois as ilustrações que escolheu para a capa são 
xilogravuras populares catalães, retiradas da revista O cavalo de todas as cores, número 1, publicada em Barcelona por João Cabral de Melo Neto, em janeiro de 1950.

Barros, em uma carta a Mindlin, comenta a capa:

Caro amigo Mindlin, Estou ainda encantado pelo trabalho dos editores. A capa cor de terra, que é a cor do que me tem. Depois a mesma cor nas maiúsculas do texto, como a acentuar o gosto pelo chão. Depois mais a escolha iluminadora da xilogravura, que ilustra bem o decomportamento da minha poesia botando língua para o estabelecido. (Barros, apud: Kikuchi (org.), 2004, p. 152).

O marrom consegue expressar muito bem o desejo pelo primordial de Barros, já que se trata de uma cor que mescla o amarelo, o azul e o vermelho, cores primárias.

Há uma cena de Dersu em que aparece um arco-íris. O goldi e os outros estão numa cabana, esperando a chuva passar. De repente Dersu levanta-se e diz que é hora de irem. Os outros dizem que chove e ele afirma: Escute bem, os pássaros estão começando a cantar. A chuva logo vai parar. Em seguida, enquanto saem o sol vai desponta à chuva fraca e lá está o arco-íris.

O arco-íris surge em um poema de O livro das ignorãças:

Durmo na beira da cor/ [...]. A chuva se engalana em arco-íris. [...]. [LI - 67].

Tal imagem está presente em outros filmes de Kurosawa, como "Kagemusha”, "Dersu Uzala" e "Dodes'ka-den”.

$\mathrm{O}$ arco-íris pode representar, em dimensões visuais, a polifonia, elemento tão caro ao cineasta. Não por acaso, ele adaptou $O$ idiota, do polifônico Fiodor Dostoiévski. Além disso, Barros filmou "Rashomon", em que um crime é contado de quatro modos diversos, por quatro narradores. Um deles é o morto, que se incorpora em uma médium, para dar seu depoimento. 


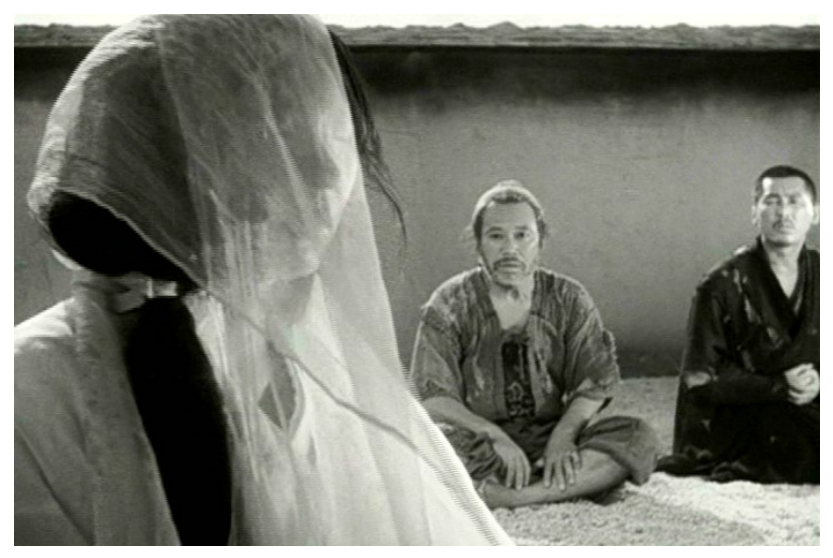

Fotograma de "Rashomon".

$\mathrm{Na}$ poética cinematográfica de Kurosawa, a presença de mortos que se manifestam é muito recorrente, vide "Trono manchado de sangue", que é uma adaptação de "Macbeth" de Shakespeare, e um episódio de "Sonhos", no qual um ex-comandante de guerra vê sair de um túnel o seu antigo pelotão, exterminado na guerra.

Nesse episódio, aparece um cachorro, que também está em "Cão danado", já na sua cena inicial: ele arfa, de língua de fora, para comprovar o discurso do narrador: Tudo aconteceu num dia terrivelmente quente. O bicho olha para a câmera e os créditos do filme aparecem.

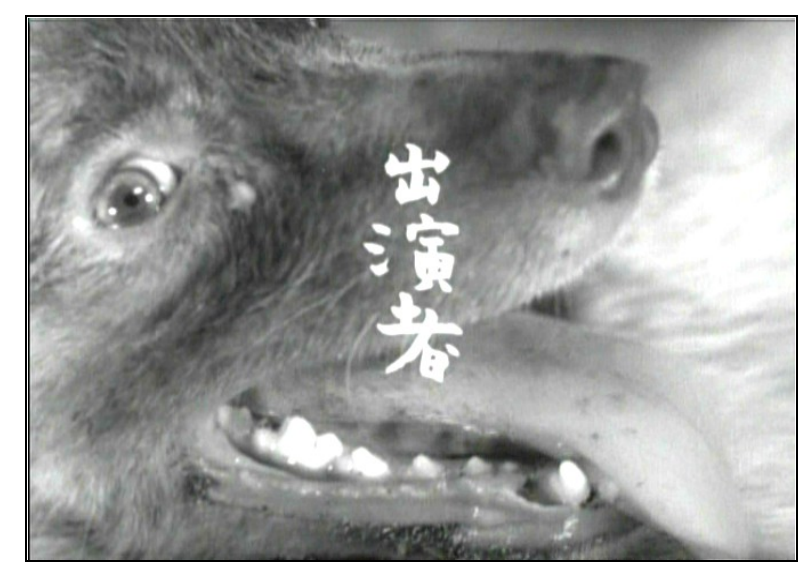

Fotograma de "Cão danado".

Um gato também aparece em um "Cão danado", ou melhor, não aparece, ele é ouvido. Seu miado é fundo sonoro para um agente da polícia ler uma carta. 
Na missiva, há estas afirmações: Outra noite insone. Ouço aquele gato do beco chorando na chuva. O que me segui pela tempestade. Ele só vai sofrer e morrer[...]. Sou um covarde como aquele gato enxarcado da chuva.

Em "Madadayo", um ex-professor de alemão convida seus antigos alunos para um jantar. Afirma que o guisado que vão comer é uma mistura de carne de veado com a de cavalo e depois mostra como foi difícil conseguir a carne eqüínea, já que estão em tempos de guerra. No açougue, o professor conta, ocorreu um fato inusitado: passou um cavalo e parou para olhá-lo, reconhecendoo. O animal era do exército, lugar em que o professor havia lecionado, anteriormente.

Ele comenta: Eu nunca pensei que um cavalo tivesse olhos tão grandes. Isso pode ser interpretado como enxergar muito, pois, no mesmo filme, um gato vê não só a materialidade que os humanos vêem mas também o invisível ligado a uma ameaça à paz do mestre. Nora, um felino, adotado pelo professor arrepia-se todo ao sentir algo de estranho na presença de um possível comprador para um terreno vizinho da casa do professor.

Aqui se pode notar uma diferença entre os olhares de Barros e Kurosawa, no caso do poeta, os animais não enxergam uma dimensão impalpável, espiritualizada. Busca-se o bicho enquanto coisa, que vê e é visto como um elemento material. A reencarnação, presente no Budismo, que é mencionada em "Madadayo", é outro elemento exclusivo do universo de Kurosawa, não sendo compartilhadas na obra manoelina. Na cena final desse filme, o protagonista sonha colorido.
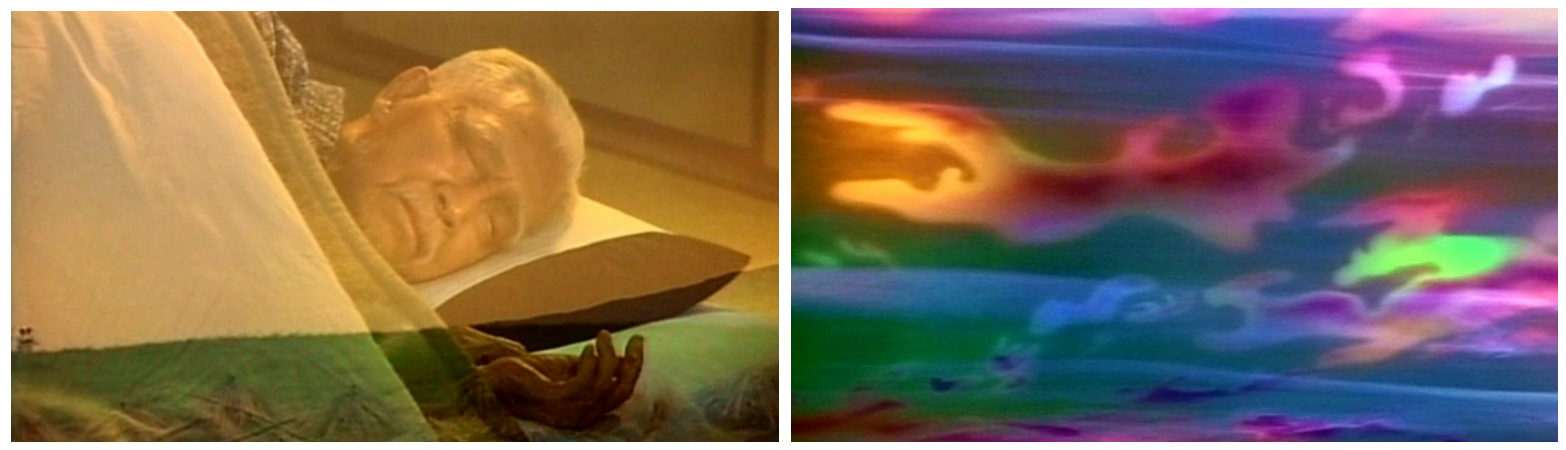

Fotogramas de "Madadayo".

Sonhar colorido é uma realidade de um filme anterior a "Sonhos" e "Madadayo": "Kagemusha". 

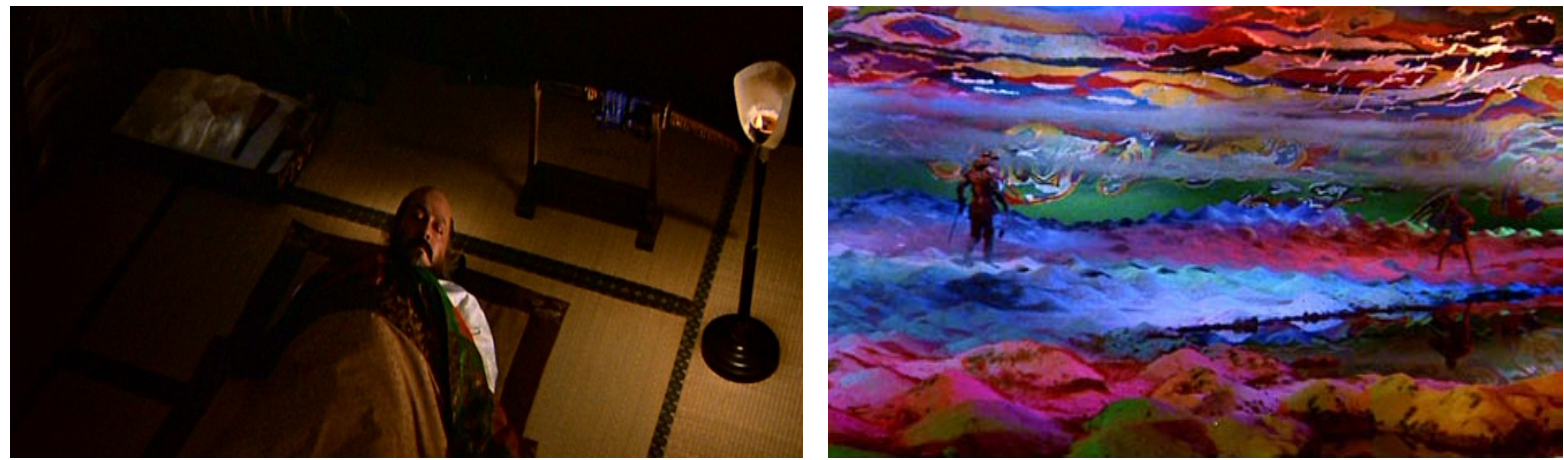

Fotogramas de "Kagemusha".

*****

Com um profundo amor pelos desprezados, como Dostoiévski, pela pintura, como Van Gogh, pela natureza, como Sombra-Boa e Dersu Uzala, o poeta dos livros Manoel de Barros e o poeta das telas Akira Kurosawa empenham-se em criar obras coloridas e polifônicas com a incumbência de humanizar os homens. Para isso, mostram que é preciso tomar árvores e bichos como paradigma.

Como na filmografia de Kurosawa, em O livro das ignorãças, aparecem muitos animais. Mas enquanto o cineasta exibe insistentemente cães e cavalos, ou seja, animais de médio e grande porte, já Barros prefere os bichos ínfimos como os insetos, que aparecem também em Arranjos para assobio, obra que será analisada no próximo capítulo. 


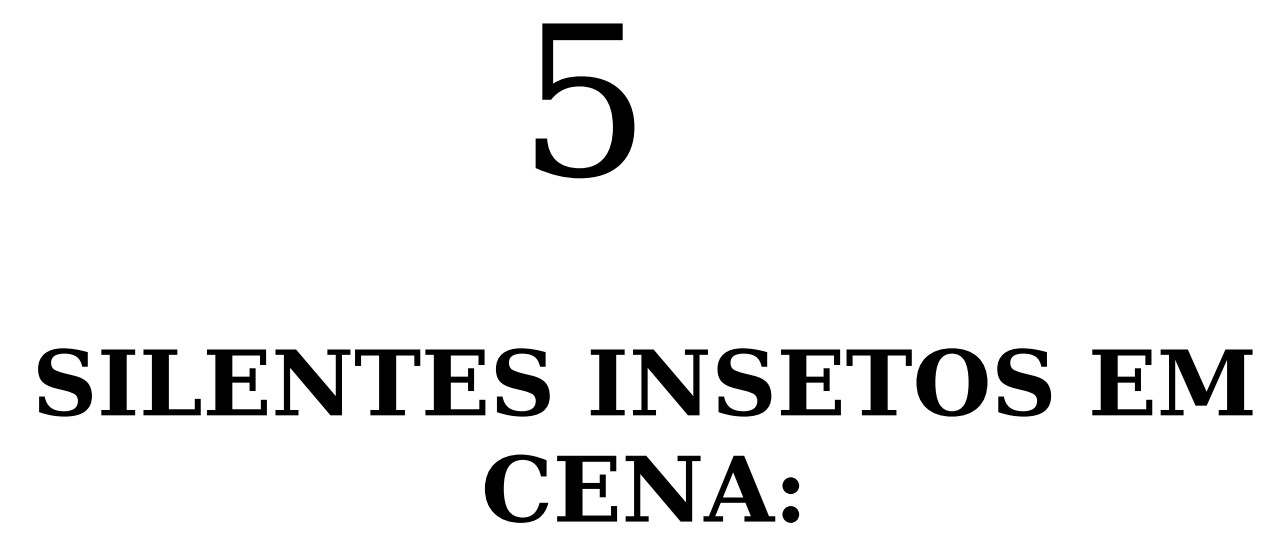

ARRANJOS PARA ASSOBIO (1982) 
Sim, eu poderia abrir as portas que dão pra dentro, Percorrer correndo corredores em silêncio, Perder as paredes aparentes do edifício, Penetrar no labirinto, o labirinto de labirintos, dentro do apartamento, 
[...] mas eu prefiro abrir as janelas pra que entrem todos os insetos.

["Janelas abertas no 2, de Chico Buarque].

\section{ENTRE VESPAS E VERSOS DESVERBADOS}

Na minha cidade tem poetas, poetas/ [...]/ Se contentam com migalhas de canções e brincadeiras com seus versos dispersos, dispersos,/ obcecados por tesouros submersos/

$\mathrm{Na}$ minha cidade tem canetas/ Esvaindo-se em milhares

de palavras retorcendo-se confusas/ em delgados guardanapos, feito moscas inconclusas.

[Lee Masliah, versão de Carlos Sandroni. "Ai, guardanapos de papel"].

Em 1982, surgem os Arranjos para assobio. No título do livro, o silêncio: os lábios em pleno assovio não entoam palavras melodiosas mas sim melodia sem palavras. Quando não assobiam, os lábios do sujeito poético desses Arranjos... tocam flauta, evitando o verbo: Sou fuga para flauta e pedra doce. [AA - 11].

A música extraída da Natureza, como a de uma pedra sem verbo, tem assim seu destaque nesse livro que teve um poema musicado por Tetê Espíndola, vide o filme Caramujo flor, de Joel Pizzini.

A cantora que já havia feito um disco com Egberto Gismonti, imitando o canto dos pássaros, aparece na mencionada película junto a uma arara. A fusão homem e animal evocada na cena do filme é recorrente no livro de Barros, além disso, persegue-se nessa obra a possibilidade de uma música sem verbo: Meu canto reboja./ Não tem margens com a palavra. Esses versos merecem destaque já que o último foi transformado por Barros. Na primeira edição de 1982, lia-se Meu canto reboja./ Não tem margens a palavra e não o que se lê nas reedições: Meu canto reboja./ Não tem margens com a palavra. [AA - 11].

Assim, o silêncio associado ao canto e ao assobio dessa obra de Barros intensificou-se e ganhou mais destaque do que já tinha na sua primeira versão. Além da quietude musical, há uma outra que se destaca em Arranjos...: o mutismo de quem se serve das palavras, mas se cala sobre seus sentidos.

Esse tipo de silêncio, como se viu, aparece em outros livros de Barros, 
mas parece que em Arranjos para assobio ele tem seu ápice. Millôr Fernandes, que elaborou sua capa, o notou, observando a complexidade dessa poesia de Barros:

[Manoel de Barros] Um tremendo poeta. Ele vive na região do Pantanal, é fazendeiro, gosta de bichos. Um dia ele mandou me pedir uma capa de livro. [...]. Aí, ao ler a poesia dele, eu descobri que era atualizada, complicada.

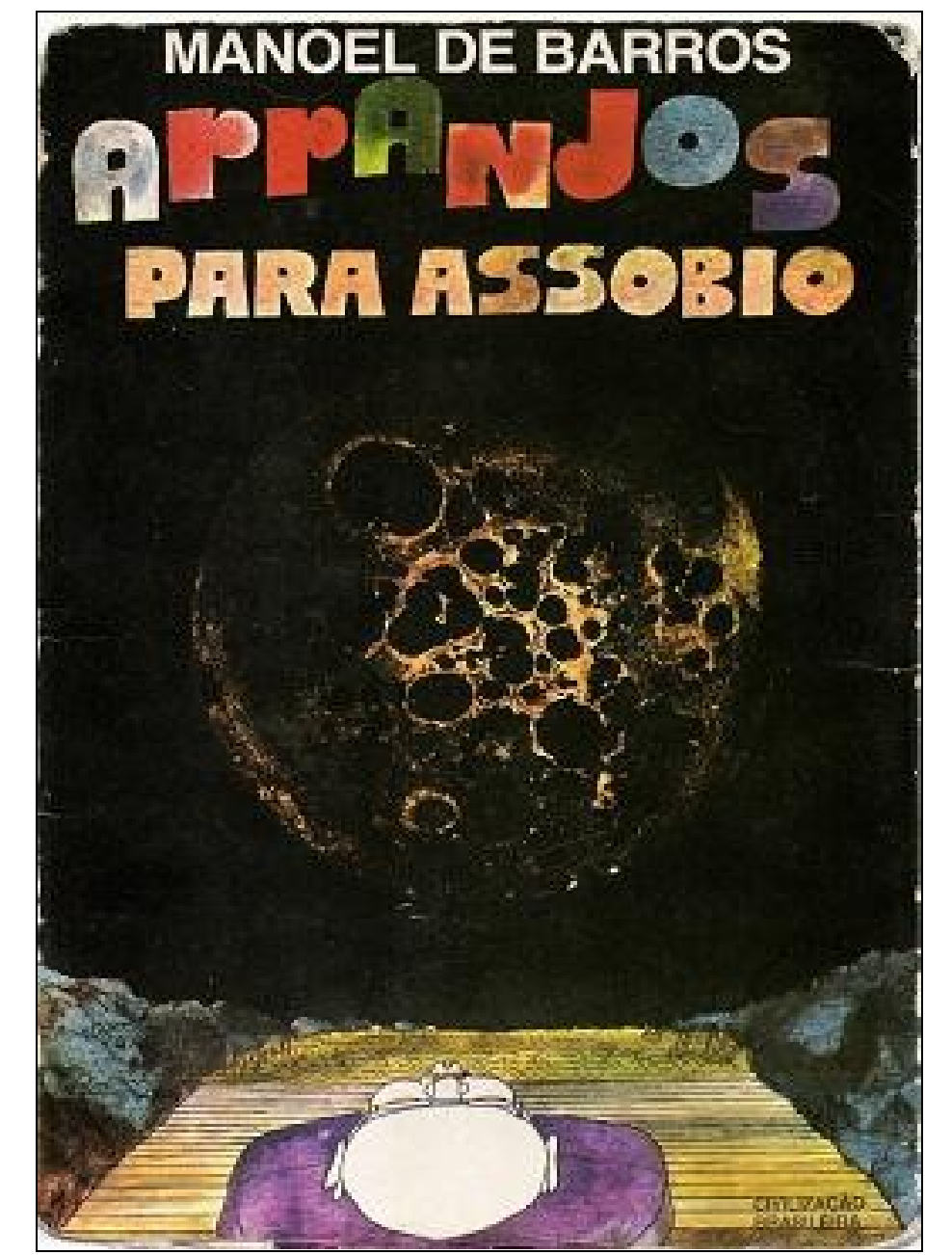

Capa de Millôr Fernandes para a primeira edição de AA.

O caráter obscuro da poesia de Barros talvez tenha inspirado Millôr na capa da obra já que predominam nela os tons escuros, apesar de o título estar em letras mais claras. Um homem olha para a escuridão na qual se vê uma forma arredondada indistinta, que pode ser a lua e suas crateras ou o topo de um crânio esburacado, talvez o do homem que olha. Outras leituras dessa imagem podem ser feitas, pois o enigma de Arranjos para assobio está posto já na sua capa. O conteúdo da obra mantém a cifra como elemento fundamental: 
as palavras incutem os silêncios de quem desexplica, de quem não denuncia com o verbo, só alude para que as ambigüidades venham à tona.

A ambigüidade se manifesta na gravura da capa das últimas edições da obra, pois se trata de uma fotografia trabalhada artisticamente por Pedro Lobo para confundir quem olha: a imagem está entre a folha e a pena.

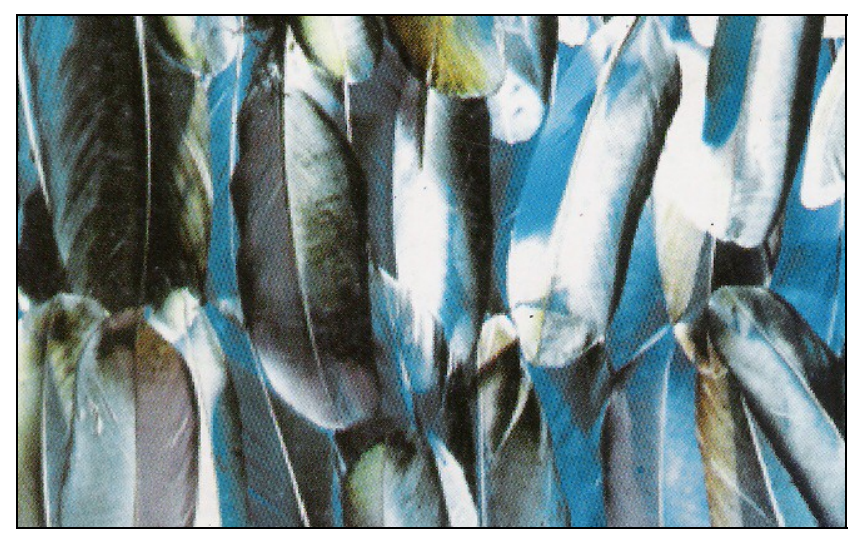

Imagem de Pedro Lobo presente nas últimas edições de AA.

Antonio Houaiss elaborou uma introdução para a primeira edição do livro, intitulada "Humildemente". Nele, o crítico escreve sobre um -ismo que se distingue dos outros: o barrismo:

O barrismo é algo diferente: uma vivênciacomunhão-inteligência com o ser-ente vivo - os "reinos" não existem, mineral, vegetal, animal, tudo e todos somos o poeta e sua poesia, sobretudo tudo $e$ todos os humildes; ser-ente em que o geral se exprime pelo concreto; em que o concreto se exprime pelo traste ou vermes ou coisinhas 'impoéticas'. [Houaiss, Antônio. Orelha de AA, 1982, p. 11].

A obra é dividida em cinco partes: "Sabiá com trevas", "Glossário de transnominações em que não se explicam algumas delas (nenhumas) ou menos", "Exercícios Cadoveos", "Exercícios adjetivos" e "Arranjos para Assobio".

A noção de obscuridade de Arranjos... se deve enormemente à eliminação dos reinos, observada por Houaiss. O universo humano amalgamase, por exemplo, com o vegetal em vários trechos da obra. A própria função do escritor, que evoca silêncios em seus escritos complexos, está associada à noção de obstrução, provocada pela hera: Sua língua era um depósito de 
sombras retorcidas, com versos cobertos de hera. [AA - 9].

A tapagem, metaforizada pela hera, é elemento basilar e fundamental para o sujeito poético de Arranjos para assobio, alterando seu modo de ver: $A$ hera veste meus princípios e meus óculos. [AA - 11].

Em um outro trecho de "Sabiá com trevas" aparece a imagem de um espinheiro:

- Quem é sua poesia?

- Os "nervos do entulho", como disse o poeta português José Gomes Fereiral Um menino que obrava atrás de Cuiabá também/ Mel de ostras/ Palavras caídas no espinheiro parecem ser (para/ mim é muito importante que algumas palavras saiam/ tintas de espinheiro.)

A imagem das palavras caídas no espinheiro remete à Bíblia: Jesus conta a parábola do homem que saiu para semear e uma parte de suas sementes caiu na estrada e foram comidas pelas aves, outra caiu nas pedras, outra, nos espinheiros e uma última, em terra fértil.

A semente que cai no espinheiro é a metáfora da palavra que não é compreendida, da mensagem que não foi atingida; assim, o sujeito poético de Arranjos para assobio faz questão de não ser compreendido por todos, tendo verdadeiro horror ao explícito.

Requerendo releituras, como a Bíblia, o texto de Barros, segundo Ênio Silveira nas orelhas da primeira edição do livro, deve ser constantemente revisitado para que descubramos sua recôndita beleza. [Silveira, Ênio. Orelha de AA].

A necessidade de releituras se deve aos escuros sentidos desse poetasabiá com trevas. A imagem desse animal é muito difundida na literatura brasileira. Ela surgiu primeiramente com Gonçalves Dias e foi retomada por Casimiro de Abreu:

Minha terra tem palmeiras,/ Onde canta o Sabiá;/ As aves que aqui gorjeiam, / Não gorjeiam como lá. [...]. ["Canção do exílio", de Gonçalves Dias].

Eu nasci além dos mares:/ os meus lares,/ Meus amores ficam lá!/ - Onde canta nos retiros/ Seus suspiros,/ suspiros o sabiá! [...].["Canção do exílio I", de Casimiro de Abreu]. 
Se eu tenho de morrer na flor dos anos,/ eu Deus!, não seja lá;/ Eu quero ouvir na laranjeira, à tarde, / Cantar o sabiá! [...]. ["Canção do exílio II, de Casimiro de Abreu].

Os modernistas dialogando com esses românticos escreveram também sobre os sabiás, cito os poemas de três autores admirados por Manoel de Barros:

\begin{abstract}
Meus olhos brasileiros se fecham saudosos/ Minha boca procura a 'Canção do exílio'./ Como era mesmo a 'Canção do exílio?'/ Eu tão esquecido de minha terra.../ Ai terá que tem palmeiras/ onde canta o sabiá! [...]. ["Europa, França e Bahia”, de Carlos Drummond de Andrade].

Minha terra tem palmares/ onde gorjeia o mar/ os passarinhos daqui/ não cantam como os de lá. [...]. ["Canto de regresso à pátria", de Oswald de Andrade].

Minha terra tem macieiras da Califórnia/ Onde cantam gaturanos de Veneza [...]. [Canção do exílio", de Murilo Mendes].
\end{abstract}

Barros optou por uma trilha nova: associar esse pássaro à obscuridade. Assim, em Arranjos para assobio, tem-se o sabiá com trevas, ou seja, o escritor que tende ao enigmático, que foge do óbvio.

Esse sabiá dá preferência ao que está em baixo das coisas. Seria uma metáfora para o silente subtexto?: A essa vida em larvas que lateja debaixo das árvores, o sabiá se entrega./ aqui desabrocharam carolas de jias! [AA, in: PQT -211].

Sentidos silenciados podem ser encontrados na profundidade que a superfície esconde ou podem ser entrevistos nas ínfimas rachaduras: Nas fendas do insignificante ele procura grãos de sol.

Esse, então, é o trabalho do leitor: procurar, no mínimo dito, significados não ditos que se ampliam em dimensões solares.

A força está, então, no não expresso, por isso o sujeito de Arranjos para 
assobio afirma que o que há de mais intenso no dizer do poeta, o sabiá, são suas trevas silentes: É ínvio e ardente o que o sabiá não diz. [AA - 36].

Se o poeta é um sabiá com seu canto obscuro e sem verbo, ele também tem parentesco com a pedra: Um homem que estudava formigas e tendia para pedras,/ me disse no ÚLTIMO DOMICÍLIO/ CONHECIDO:/ Só me preocupo com as coisas/inúteis. [AA - 9].

Um verso de Alberto Caeiro é citado: Pedras fazem versos? Pergunta de Fernando Pessoa. [AA - 38]. Se fazem, devem evidenciar inarticulabilidades, principalmente os ligados aos significados. Para silenciar, usando o verbo, o sujeito poético de Arranjos... se propõe a distorcer as palavras: Amo arrastar algumas delas no caco de vidro/ envergá-las pro chão, corrompê-las - Até que padeçam de mim e me sujem de branco. [AA - 19].

Essa distorção das palavras, que as aproxima do silêncio, continua a ser feita na segunda parte do livro "Glossário de transnominações em que não se explicam algumas delas (nenhumas) ou menos". É dado um verbete e depois é mostrada a sua significação, no entanto, a explicação desexplica, ou seja, o esclarecimento obscurece, porque o que importa é o lirismo e o não entender. Manoel faz, pois, o caminho contrário dos dicionários, apesar de imitá-los na estrutura. Tomemos o termo boca, que Tetê Espíndola musicou e cantou no filme "Caramujo flor":

$$
\text { Boca, s. f. }
$$

Brasa verdejante que se usa em música

Lugar de um arroio haver sol Espécie de orvalho cor de morango Ave-nêspera!

Pequena abertura para o deserto [AA - 44].

O que teria um significado simples, na linguagem usual, é problematizado, na escrita manoelina, talvez porque um sentido mais profundo é buscado em cada palavra como o de pequena abertura para o deserto para definir a boca, ou seja, é possível entender aqui que a boca humana (as palavras) é por demais limitada para expressar a imensidão das sensações e dos sentimentos da alma, que parece estar metaforizada na imagem do 
deserto. Talvez, para se aproximar dessa noção do ilimitado, o sujeito poético não usa ponto final depois da definição de cada vocábulo. Assim, o sentido não se finaliza depois de cada explicação complexa e lacunar.

Em 1990, a Arte Pau-Brasil, de São Paulo, editou cartões postais com os verbetes desse glossário, com projeto gráfico e ilustrações de Paulo Alves de Lima.

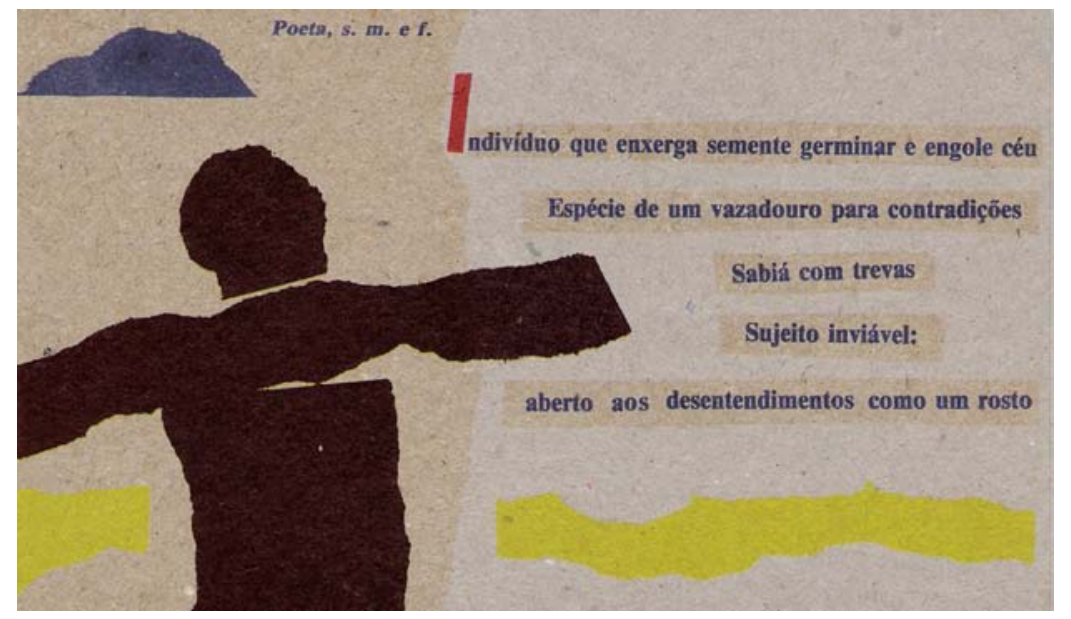

Cartão postal criado por Paulo Alves de Lima.

A arte de Paulo evidenciou o silêncio do "Apêndice" desse glossário já que destacou a letra o, graficamente equivalente ao zero, do primeiro e do último versos. A partir das iniciais, tem-se OCO, espaços mudos em que cabem muitos sentidos.

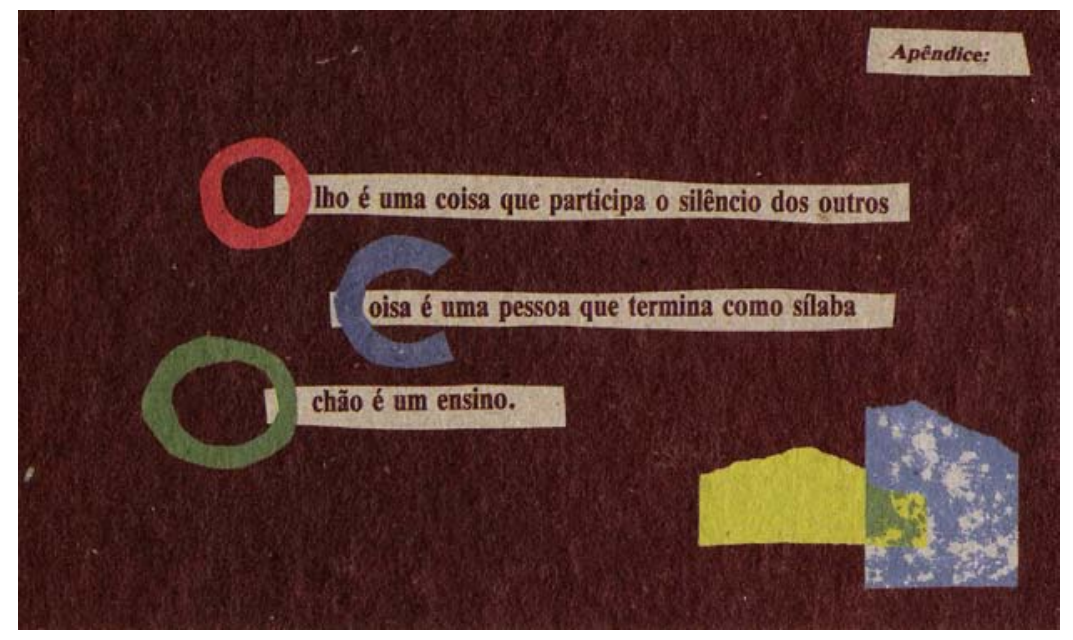

O significado do verbete cisco está pleno de ocos silenciais, tanto no texto quanto na imagem de Paulo: 


\title{
Cisco,
}

\author{
s. $m$.
}

Pessoa esbarrada em raiz de parede Qualquer indivíduo adequado a lata Quem ouve zoadas de brenha. Chamou-se de O CISCO DE DEUS a São Francisco de Assis Diz-se também de homem numa sarjeta

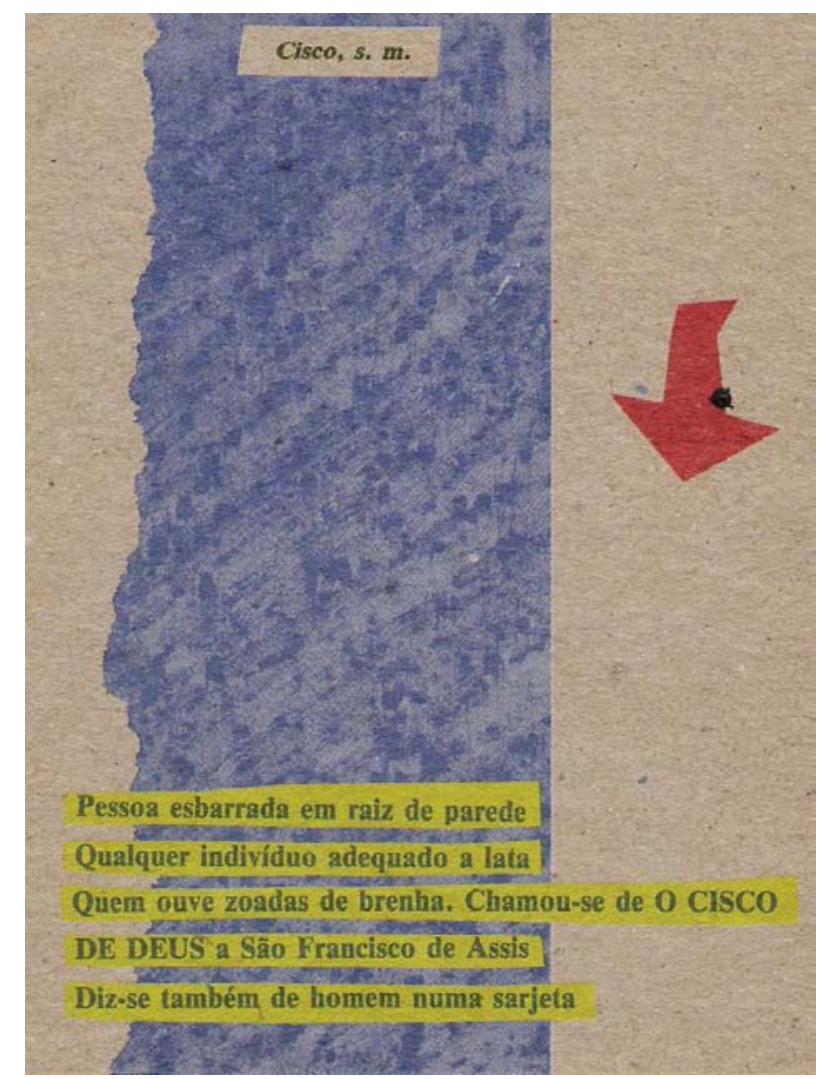

Em quase todos os sentidos desse termo, aparece o homem que socialmente é tratado como cisco. São os que não têm voz e se caracterizam pela sua pequenez: os silenciados homens-ciscos. Eles são adequados à lata, pois podem ser jogados fora como tal; eles estão propensos a morarem na sarjeta da cidade ou a se enfiarem na brenha, ou seja, no mato e, em sua quietez de escuta e solidão, põem-se a ouvir as zoadas do matagal.

Preocupado justamente com os ciscos, São Francisco de Assis, em silêncio, sempre tendeu a observar e a ouvir esses pequenos, tanto os homens quanto os bichos. Por isso, outro significado desse verbete é São Francisco de Assis, o cisco de Deus. 
Vários desenhos de Manoel de Barros lembram a figura desse santo.
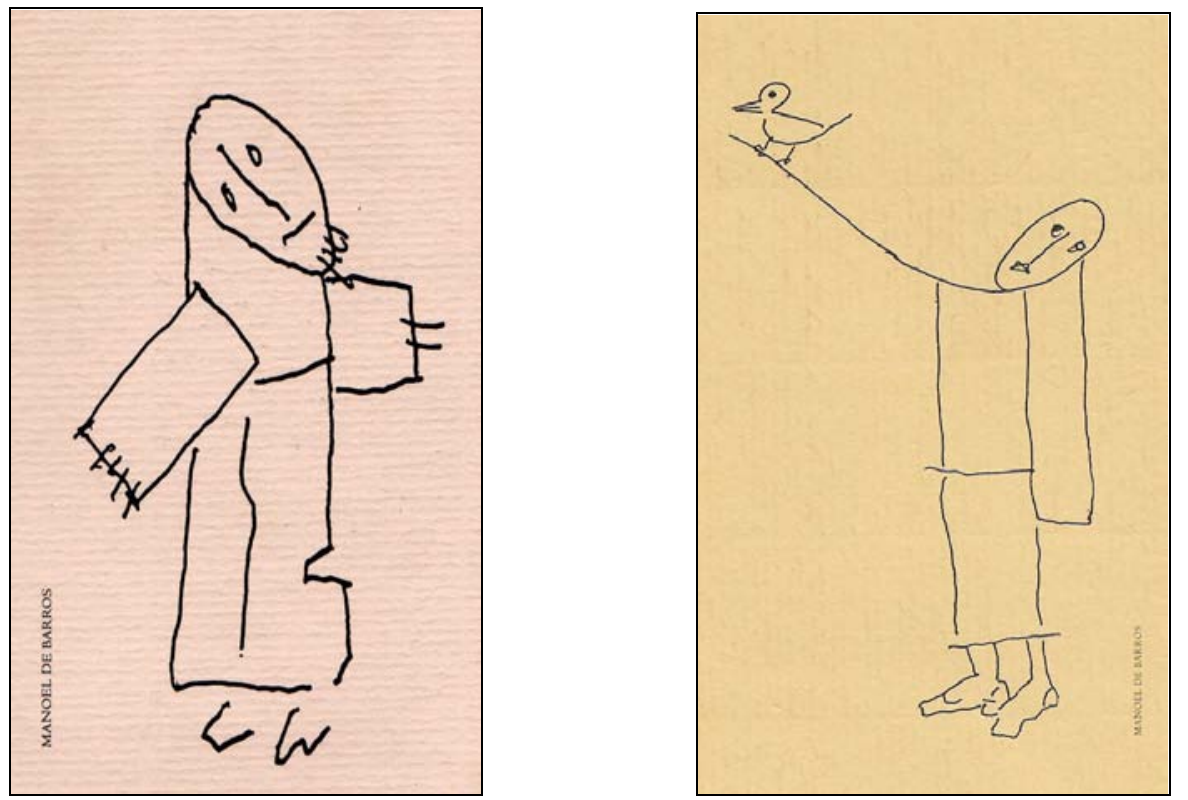

Desenhos de Manoel de Barros da quarta capa, respectivamente, de CCASA e LN; a batina lembra a de São Francisco de Assis, assim como a proximidade com os pássaros.

Elena Vássina observou que os desenhos de Barros lembram imagens de Picasso $^{38}$. Isso se comprova se observarmos esses dois homens cujo rosto lembram aqueles dos quadros do pintor espanhol na fase primitivista.

O quarto poema de "Sabiá com trevas" tem a seguinte dedicatória: $A$ um Pierrô de Picasso. O poema é este:

Pierrô é desfigura errante,/ andarejo de arrebol./ Vivendo do que desiste,/ Se expressa melhor em inseto./ Pierrô tem um rosto de água que se aclara com a máscara./ Sua descor aparece/ como um rosto de vidro na água.

A máscara citada seria a africana que inspirou Picasso a iniciar o movimento cubista com "Les mademoiselles d'Avignon"? O pintor espanhol, com o Primitivismo, buscava questionar a sociedade "avançada", já que, para ele, civilização era sinônimo de invenção de bombas e tantas outras barbáries.

As conseqüências do impacto visual de Picasso, diante da máscara

\footnotetext{
38 Elena afirmou isso no curso de Pós-Graduação "Folclore, literatura popular e literatura erudita: problemas de linguagem nas abordagens teóricas russas do século XX", oferecido no primeiro semestre de 2003, na Universidade de São Paulo.
} 
africana, são descritas em Livro sobre nada: Lembrei que Picasso depois de ver as formas bisônticas na África, rompeu com as formas naturais, com os efeitos de luz natural, com os conceitos de espaço e perspectiva, etc etc. E depois quebrou planos, ao lado de Braque, propôs a simultaneidade das visões, a cor psíquica e as formas incorporantes. (LN - 74).

A simultaneidade das visões em Picasso é buscada pelo enunciador de Memórias inventadas: a segunda infância: Tentei montar com aquele meu amigo que tem um olhar descomparado, uma Oficina de Desregular a Natureza. Mas faltou dinheiro na hora para a gente alugar um espaço. Ele propôs que montássemos por primeiro a Oficina em alguma gruta. [...]. Por último aproveitamos para imitar Picasso com A moça com o olho no centro da testa. Picasso desregulava a natureza, tentamos imitá-lo. Modéstia à parte. [MISI - sem paginação].

O Pierrô de Picasso se expressa melhor em inseto. Assim, melhor do que se expressar em português, árabe, francês, russo etc... Ele opta por falar em inseto.

O artista usou uma borboleta em uma de suas composições.

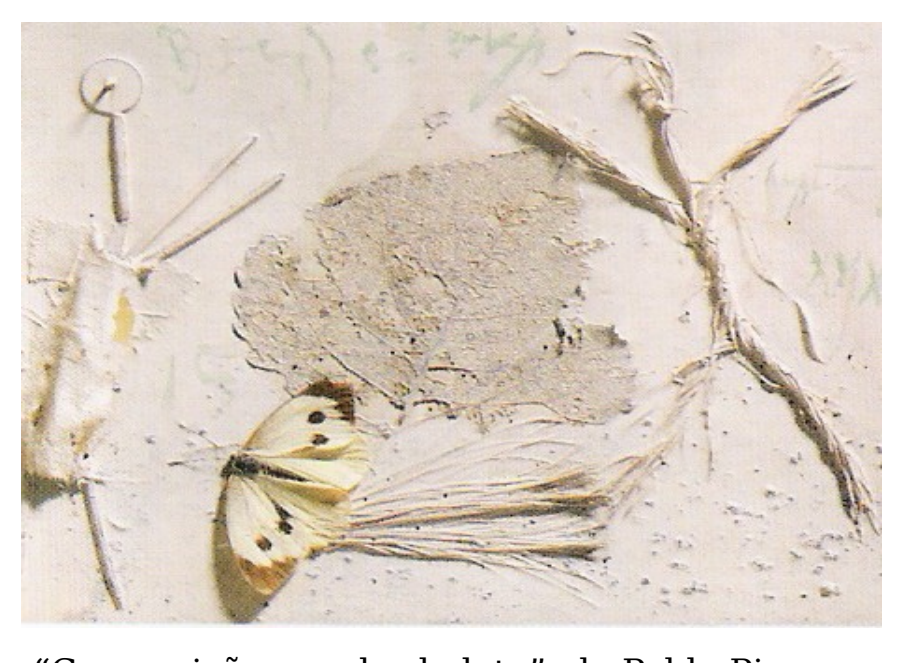

“Composição com borboleta”, de Pablo Picasso.

Em um trecho de "Sabiá com trevas", lê-se: Há mistérios nascendo por cima das palavras, desordenadamente, como bucha em taperal e moscas portadoras de rios. [AA - 39]. Se moscas portam rios é porque silenciosamente os sentidos das palavras ampliam-se, requerendo a atenção redobrada do leitor 
que deve ater-se aos detalhes do escrito que contêm o não dito ${ }^{39}$.

Um homem-inseto surge em Arranjos para assobio num poema da primeira parte de Arranjos... Agora a associação é feita com a vespa: Usado por uma fivela, o homem tinha sido escolhido, desde criança, para ninguém e nem nunca. De forma que quando se pensou em fazer alguma coisa por ele, viu-se que o caso era irremediável e escuro. Ou uma vespa na espátula. [AA $17]$.

Parte da obscuridade de Arranjos para assobio se deve à enorme incidência de citações explícitas e implícitas a outros autores e a outras obras. Além do heterônimo pessoano Alberto Caeiro, outras vozes são ouvidas no livro.

Em um número especial da Poetique, André Topia, no ensaio "Contrapontos joycianos" explica como é esse obscuro emaranhado de referências textuais em T. S. Eliot, James Joyce e Ezra Pound:

O estatuto do citacional é o lugar simultaneamente central e problemático em que se joga a escrita desde o fim do século XIX. De fato, cada vez mais o texto literário se inscreve numa relação com a multidão dos outros textos que nele circulam. Ao tornar-se o receptáculo móvel, o lugar geométrico dum fora-do-texto que o percorre e informa, deixou de ser um bloco fechado por fronteiras estáveis e instâncias de enunciação claras. [...] Disso é testemunha a sua perplexidade face a obras como The waste land de T. S. Eliot, Ulisses de Joyce ou os Cantos de Pound.[Topia, s. d., p. 171].

\footnotetext{
${ }^{39}$ Katherine Mansfield também usou esse inseto para escrever um texto pleno de silêncios: o conto "A mosca". Nele, o velho Woodifield senta-se diante de seu chefe e conversa. Quer falar algo, mas não se lembra do que é; depois de vários assuntos ligeiros, recorda-se: suas filhas viajaram para Bélgica para visitar o túmulo de Reggie e do lado dele estava o túmulo do filho do chefe. Esse comentário gera silêncios: O velho Woodifield fez uma pausa, mas o chefe não respondeu nada. Apenas um tremor de pálpebras indicou que ele tinha ouvido. [...] "Você nunca foi lá, não é?"/ "Não, não". [...]/ "São quilômetros de cemitério [...] e tudo parece um jardim. Com flores, em todos os túmulos. Alamedas bonitas, largas."/ Mais uma pausa se fez. [Mansfield, 2005, p. 261]. Depois que Woodifield saiu, seu chefe nota que uma mosca tenta sair do seu tinteiro; ele pega uma pena, retira-a de lá e a coloca em pedaço de mata-borrão, observando todo os primeiros movimentos difíceis do inseto, tentando a custo tirar com as patinhas da frente tirar a tinta da cara, como um gatinho que se lambe. Depois de muito trabalho sofrido, quando ela está prestes a voar, o homem, mergulha a pena na tinta e deixa cair uma gota pesada sobre o pequeno bicho. A luta do inseto para se livrar da morte e o desejo do homem de observar a sua reação diante daquela vicissitude ciclicamente se repetem por mais três vezes e se interrompem. O homem joga no lixo o cadáver e o mata-borrão, pede um novo à secretária e, aí, sente uma repentina infelicidade, mas logo se desvencilha dela, tentando lembrar do que pensava antes do surgimento da mosca.
} 
Não por acaso, Joyce e Eliot são citados em Arranjos para assobio. Na terceira parte do livro, "Exercícios Cadoveos", lê-se:

Estes inutensílios foram colhidos entre os mitos Cadiuéus, narrados pelo Professor Darcy Ribeiro. Resguardando-se petulância e distância, exercitouse aqui a moda posta em prática por Eliot incorporando à sua obra versos de Shakespeare, Dante, Baudelaire. E o que fez um pouco James Joyce aproveitando-se de Homero. E ainda o que fez Homero aproveitando-se dos rapsodos gregos. Ai pobres Cadoveos! Este bugre Aniceto aí da frente é que vai perpetuar vocês? Nem xum.

Esse trecho aparece como nota de rodapé dos sete inutensílios de Aniceto, um índio que usa um instrumento de voar que prende nos cabelos como os poetas. Um detalhe: o sétimo inutensílio não está escrito, ele está presente no silente espaço em branco.

Fica patente, então, uma perseguição à palavra cada vez mais antiga, ou seja, o discurso de um autor é associado ao dos seus antecedentes até que se atinja o princípio: a expressão primitiva, próxima do silêncio, que é representado no espaço em branco.

Assim, muitas palavras de Eliot vieram de Shakespeare, Dante e Baudelaire. Muitas palavras de Joyce vieram de Homero. Muitas palavras de Homero vieram dos rapsodos gregos. E todas essas palavras são perpetuadas pelo silêncio da linguagem pré-verbal do índio Aniceto.

Os primevos inutensílios de Aniceto ficam no mesmo patamar de importância do Ulisses, de Joyce, e do Terra desolada, de T. S. Eliot (é nesse poema que o autor norte-americano cita Shakespeare, Dante, e Baudelaire, nomes que aparecem nesse poema de Barros). Assim, o índio, tratado pela sociedade como um ser menor (não por acaso seu nome é Aniceto, que lembra inseto), cria coisas tão grandiosas quanto as duas obras célebres mencionadas.

O amálgama entre os reinos animal, vegetal, mineral e hominal é próprio da cultura indígena. Não por acaso, em "Exercícios adjetivos", a quarta parte de Arranjos..., aparece uma casa terena. Os índios Terena, com exceção de um 
grupo que vive no interior de São Paulo (Áreas Indígenas Araribá e Icatu), vivem em Mato Grosso (na margem esquerda do alto rio Paraguai) e em Mato Grosso do Sul (a leste do rio Miranda e a oeste (na Reserva Indígena Kadiwéu).

O processo de adjetivação de um substantivo é a base de "Exercícios adjetivos"; assim, além da casa terena, aparecem os barrancos ventados, as pernas areientas de um lagarto, as rolinhas casimiras, uma voz pelada de peixe e nem mesmo o silêncio escapa dessa dinâmica: ele é rubro.

Na quinta e última parte, homônima ao livro, o silêncio é mencionado em "O pulo": Estrela foi se arrastando no chão deu no sapo/ sapo ficou teso de flor!/ e pulou o silêncio.[AA - 71]. Em outro poema, um prisioneiro cumprimenta respeitosamente as moscas, inclusive por que elas anunciam a morte que está próxima: Na cela de Pedro Norato, 23 anos de reclusão; a morte sesteava de pernas abertas.../ Sem amor é que encontramos com Deus, me diz./ O mundo não é perfeito como um cavalo, - me diz./ Vê trinos de água nos relógios./ E para moscas bate continências. [AA - 67].

Se as moscas, que na primeira parte do livro, eram portadoras de rios e ao fim dele são dignas de continências, se o pierrô de Picaso se expressa melhor em inseto, se surgem homens-vespas, se o nome do índio é Aniceto. Então, faz-se necessário observar os sentidos do verbete inseto, que serão analisados na próxima seção.

\section{PATAS, ANTENAS E ASAS DOS SILÊNCIOS}

não era acaso um sono provisório esse outro sono, ter [...] minha testa fria coberta de insetos, minha boca inerte beijando escaravelhos? [...] e, quando já tivermos, debaixo de um céu arcaico, tingido nossos dentes com o sangue das amoras colhidas no caminho, só então nos entregaremos ao silêncio, vasto e circunspecto, habitado nessa hora por insetos misteriosos [Raduan Nassar. Lavoura arcaica]. 
Inseto, s. m.

Indivíduo com propensão a escória

Pessoa que se adquire da umidade

Barata pela qual alguém se vê

Quem habita os próprios desvãos

Aqueles a quem Deus gratificou com a sensualidade

[vide Dostoievsky, Os Irmãos Karamazov] [AA 45].

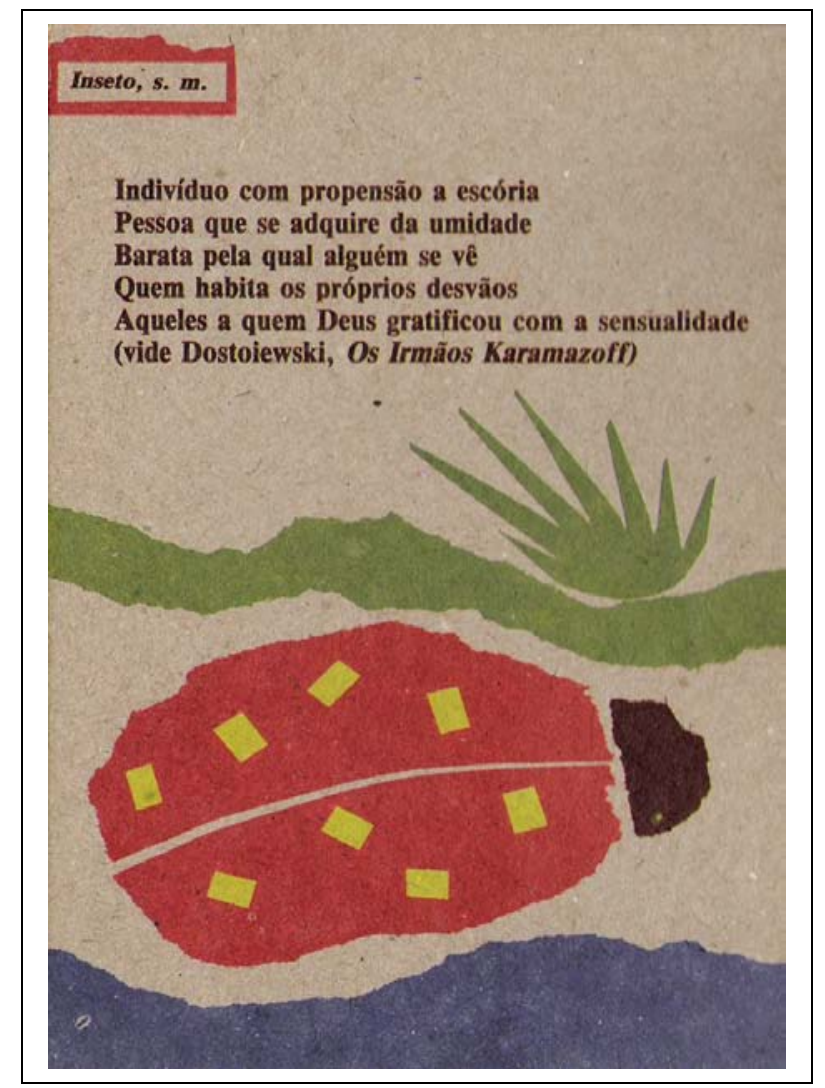

Cartão postal de Paulo Alves de Lima para inseto.

Mário de Andrade, em "O besouro e a rosa", narrativa que está no livro Contos de Belazarte, explorou a imagem do inseto que aparece no título do seu texto. Metáfora da sensualidade, esse pequeno ser morde o peito e a genitália de Rosa, numa noite em que deixou a janela aberta. Depois dessa primeira experiência, ela passa a esperar a vinda desse misterioso e ardente ser.

Os irmãos Karamazov foi elegido por Mário como um dos dez melhores romances do mundo. Nessa obra, ocorre a associação entre inseto e sensualidade: Quero falar-te agora sobre os "insetos", aqueles a quem Deus deu a volúpia. "Ao inseto... a volúpia". Eu é que sou esse inseto, irmãozinho, é 
a mim que se refere o verso. Todos nós, nós os Karamazov, somos assim; e também dentro de ti, que és um anjo, vive o inseto, que engendra tempestades no teu sangue. A beleza... é uma coisa tremenda e espantosa. Tremenda porque é infinita, e não se pode defini-la, porque Deus não nos propôs senão enigmas. Nela os extremos se reúnem, nela todas as antíteses vivem juntas. [Dostoiévski, 1952, 1.o vol., p. 241-242].

Esse trecho do livro dostoievskiano chamou a atenção de Barros, tanto que ele inseriu sua idéia principal no poema em análise: Aqueles a quem Deus gratificou com a sensualidade/ [vide Dostoievsky, Os Irmãos Karamazov] [AA 45].

A complexidade dos personagens dostoievskianos - que apresentam uma beleza na qual todas as antíteses vivem juntas - contamina o sentido do verbete em questão, que pode tornar-se ainda mais denso e difícil se se pensa no seu primeiro enunciado: Indivíduo com propensão a escória.

Se Dostoievski é mencionado nas linhas do poema, pode-se aguçar o olhar para tentar enxergar nas entrelinhas dele a presença de Franz Kafka e sua $A$ metamorfose. Gregor Samsa, ao se transformar em inseto, não gera mais a renda da família. Assim, recebe o desprezo dela, ou seja, é um indivíduo com propensão a escória.

Em Arranjos para assobio, lê-se este outro poema:

Quando houve o incêndio de latas nos fundos da Intendência, o besouro náfego saiu/ caminhando para alcançar meu sapato (e eu lhe dei um chute?)/ Parou no ralo do bueiro, olhoso como um boi/ que botaram no sangradouro dele/ [Intrigante: não sei de onde veio nem de que lado de mim entrou esse besouro. Devo ter maltratado com os pés, na minha infância, algum pobre-diabo. Pois como explicar/ o olhar ajoelhado desse besouro?)/ Com seu casaco preto, chamuscado nas pontas, ele em seguida nafegou no rumo do jardim e entrou no porão de um coreto por onde se comeu como um papel sem gosto/ De manhã, catando pelas ruas toda espécie de coisas que não pretendem, sempre eu revejo esse ente que tem por abrigo o céu, como conchas ao contrário]. [AA, in: PQT $-203]$. 
Daniela $\mathrm{Kahn}^{40}$ associou o besouro náfego desse poema com o mencionado protagonista kafkiano, porque, depois de metamorfoseado, começa a mancar por ter sido atingido por uma maçã. A sensível leitora e releitora de Barros e Kafka observou que, em certa passagem da célebre novela do autor tcheco, o protagonista é chamado de besouro pela empregada ${ }^{41}$.

Repletos de silêncios nas entrelinhas, os escritos de Kakfa exigem releituras, como percebeu Albert Camus, o que foi comentado no primeiro capítulo desta tese. O autor cuiabano é leitor não só do escritor tcheko, mas também dos que o lêem e o relêem, como se vê nesta entrevista: Em estudo sobre O processo, de Kafka, o humanista Gunters Anders, observa o amor de Leni pelos processados. Leni acha que a miséria da culpa os torna belos. Sua compaixão pelas vítimas é que a leva ao amor. De muita dessa compaixão é feita a poesia de nosso século. Um fundo amor pelos humilhados e ofendidos de nossa sociedade banha quase toda a poesia de hoje. Esse vício de amar as coisas jogadas fora - eis a minha competência. É por isso que eu sempre rogo pra Nossa Senhora da Minha Escuridão, que me perdoe por gostar dos desheróis. Amém. [Manoel de Barros em entrevista, In: Gramática expositiva do chão: poesia quase toda, 311].

O desherói Gregor Samsa, na forma de enigmático inseto, passa a se manifestar numa língua que equivale ao silêncio para os outros da sua família, já que ninguém o entende. Assim, socialmente enxotados, o náfego homembesouro de Arranjos... e Gregor Samsa compreendem-se em sua mudez e na condição de serem pequenos socialmente. O silêncio dos sem voz soma-se ao silêncio do escrito que, mudamente, comunica nas entrelinhas.

Quem habita os próprios desvãos. Essa é outra definição de inseto, no poema em análise, e ela pode ser associada ao próprio silêncio daquele que é eloquente e tem força na incompletude, que bem pode ser a lacuna silente do seu próprio discurso.

Quanto mais o texto diminui, como é o caso desse verbete inseto, mas aparecem os silêncios nos seus desvãos e não se apreendem, na primeira

\footnotetext{
40 Em conversa ocorrida em setembro de 2005.

41 Em nenhum outro momento de "A metamorfose", o inseto no qual Gregor se transformou é nomeado.
} 
leitura, os seus sentidos mais fundos: são necessárias leituras vindouras. Os significados que faltam podem surgir no devir, assim o escrito se mostra inacabado, esperando a contribuição semântica do leitor. Gilles Deleuze relaciona isso ao devir-animal: Escrever não é certamente impor uma forma (de expressão) a uma matéria vivida. A literatura está antes do lado do informe, ou do inacabamento, [...]. Escrever é um caso de devir, sempre inacabado, sempre em via de fazer-se, e que extravasa qualquer matéria vivível ou vivida. É um processo, ou seja, uma passagem de Vida que atravessa o vivível e o vivido. A escrita é inseparável do devir: ao escrever, estamos num devir-mulher, num devir-animal ou vegetal, num devir-molécula, até num devirimperceptível.

Barata pela qual alguém se vê. Aqui, como n'A paixão segundo $G H$, de Lispector, é pelos olhos que se apreende um realidade cifrada e indizível. GH mira uma barata e vê nela Janair, a sua empregada, depois vê a si própria e, finalmente, Deus. Assim, justamente o ser indesejado, enxotado, em alguma medida, lembra a existência divina ou relaciona-se fortemente a ela. Busca-se uma linguagem para expressar isso e depara-se com a falha, com a dificuldade no dizer, restando, então, o inexprimível: Ah, mas para se chegar à mudez, que grande esforço da voz. Minha voz é o modo como vou buscar a realidade; [...]. A realidade é a matéria prima, a linguagem é o modo como vou buscá-la $-e$ como não acho. Mas é do buscar e não achar que nasce o que eu não conhecia [...]. A linguagem é o meu esforço humano. Por destino tenho que ir buscar e por destino volto com as mãos vazias. Mas volto com o indizível. O indizível só me poderá ser dado através do fracasso de minha linguagem. Só quando falha a construção, é que obtenho o que ela não conseguiu".

Também em Manoel de Barros, o encontro com o inseto revela o encontro com uma essência divina e com o indizível: os entregues ao abandono e ao desprezo são manifestações de Deus; a religião na obra manoelina, estaria ligada, inclusive, à tarefa de amar os não amados e buscar uma linguagem abrangente para a expressão disso. Então, depara-se com o silêncio ${ }^{42}$.

\footnotetext{
$\overline{42} \mathrm{O}$ verso barata pela qual alguém se vê dialoga também com outro texto de Lispector: "A quinta história", que foi publicado no mesmo ano de $A$ paixão..., 1964, fazendo parte do livro $A$ legião estrangeira. A história de uma dona de casa que mata baratas é recontada de várias formas. Daniela Kahn, no seu livro A via crucis do outro: identidade e alteridade em Clarice Lispector, analisa os desdobramentos da narrativa, afirmando que se, na primeira versão da história, existe uma objetivação no seu conteúdo e estilo, por outro lado, na segunda versão,
} 
Menor que a barata, a formiga é eleita na obra de Barros como a representante de seus apequenados e ofendidos. Aquele que, em termos de valorização da sociedade, tem o tamanho de um inseto cresce e tem seu lugar de destaque na poesia manoelina e, diante da amplidão de seu sentido, surge o silêncio, a mudez: Não precisei de ler São Paulo, Santo Agostinho,/ São Jerônimo, nem Tomás de Aquino, nem São Francisco de Assis - / Para chegar a Deus./ Formigas me mostraram Ele./ (Eu tenho doutorado em formigas.) [EF].

Nesse caso, parece que a discussão verbal sobre Deus, feita por esses santos, foi substituída pela experiência silenciosa de se ver uma formiga. Deus, na obra de Manoel, aparece mais como um ente para ser visto do que comentado, revelando-se silenciosamente nos seres, nas coisas.

Assim, se a barata é, ao mesmo tempo, Deus e Janair, também a formiga, em Barros, é ao mesmo tempo a presença divina e a dos socialmente ínfimos. Então é mais fácil entender este verso de Tratado geral das grandezas do ínfimo: Reconhecer a eminência dos insetos leva à sabedoria. [TGGI - 60].

Se a eminência pode ser entendida como o elevado, o sublime, então o altivo se revela no rasteiro, ou seja, nesses ínfimos seres.

Daniela Kahn, ao analisar a associação de homens com insetos em $A$ paixão segundo $G H$, de Clarice Lispector, "A metamorfose", de Kafka, e El cuarto de atrás, de Carmen Martin Gaite, mostra que se pode compreender tal relação, típica da literatura moderna, com uma observação de Northrop Frye. O crítico canadense, em $A$ anatomia da crítica, classifica cinco tipos de herói: $o$ mítico, que é um deus superior em condição aos homens e ao meio; $o$ romanesco, que é um homem superior em grau aos homens e ao meio; o do imitativo elevado, que é um líder superior aos homens mas não ao meio; o do imitativo baixo, que é um homem que está no mesmo patamar de força e inteligência que o nosso; o irônico, que é um homem que apresenta inferioridade com relação ao leitor em termos de poder e de inteligência.

Assim, a partir dessa classificação de Frye, Daniela faz a seguinte leitura desse gosto dos escritores do século XX de associar o homem ao inseto: Com principia uma subjetivação do texto, ocorrendo uma progressiva identificação da narradora com as baratas. A humanização das baratas ocorre concomitantemente com a "baratização" da narradora: "Como para baratas espertas como eu...". Na terceira história, a associação entre inseto e homens amplia-se quando se associa a mortandade das baratas com a destruição de Pompéia. 
efeito, o herói mítico da antigüidade perde primeiro a sua divindade, depois os seus poderes sobrenaturais, em seguida o seu posto de líder, tornando-se cada vez mais homem e cada vez menos herói, deixando finalmente para trás a sua própria humanidade para converter-se num ser, de proporções infra-humanas, o irônico herói do século XX. O inseto ou a barata seria, pois, uma das inúmeras formas de representação do homem [...] na sua trajetória de desheroização [Kahn, 1994].

Se, com o passar do tempo, o tipo de herói muda, também se transforma o seu olhar, como aponta Daniela:

O "encolhimento" do herói vem acompanhado de uma correspondente redução da perspectiva espacial. O olhar míope desse ser achatado, [...], há muito já não se dirige para o alto nem busca abarcar distâncias, detendo-se apenas no que é próximo e rasteiro, limitando-se freqüentemente a esquadrinhar os detritos do lixo que esta mesma civilização decadente acumulou ao seu redor. Para ele o mundo transformou-se num grande quarto de despejos. [Kahn, 1994].

Essas palavras dirigidas às obras de Kafka, Gaite e Lispector servem perfeitamente para a obra de Barros. Afinal de contas, o sujeito manoelino quer, justamente, o que jogam fora, os inutensílios, que são matéria de poesia. Assim, interessam na poética de Arranjos para assobio, não só as coisas jogadas fora, mas os próprios homens tratados como lixo, "encolhidos" como um besouro, qual Gregor Samsa, ou como uma formiga, qual Bernardo: Formiga é um ser tão pequeno que não agüenta nem neblina. Bernardo me ensinou: Para infantilizar formigas é só pingar um pouquinho de água no coraçãozinho delas. Achei fácil.[ LN].

Assim, dos homens-formigas manoelinos, destaca-se esse Bernardo: um roto andarilho que tem a delicadeza de mexer com seres esquecidos e pequenos como ele.

Em Tratado geral das grandezas do ínfimo, pode-se fazer uma leitura sociológica dos muitos pequenos que devoram um grande: Cerca de dez formigas/ Tentavam arrastar um caranguejo até a entrada da casa delas./ Mas não puderam recolher o caranguejo na casa./ Porque a porta da casa era muito estreita./ Então as formigas almoçaram aquele caranguejo ali mesmo. Elas 
penetravam por dentro do caranguejo e comiam as substâncias de dentro./ De outra feita eu vi uma formiga solitária a puxar de fasto/ Um mandarová morto./ Ela puxava de fasto e nada./ Não arredava do lugar um centímetro./ A formiga foi chamar as companheiras,/ As companheiras vieram em bando, muitas./ E almoçaram o mandarová ali mesmo./ O pitéu estava até desmanchando... ${ }^{43}$ [TGGI - 15].

Em um trecho de Retrato do artista quando coisa, lê-se:

$O$ rio cortava a tarde pelo meio/ De um lado passeavam cavalos,/ De outro lado - Passo Triste, aves e borboletas. [...]. [RAQC -43].

Nesse retrato, os cavalos ficam de um lado e do outro Passo-Triste, as aves e as borboletas. A imagem parece indicar que, nesse universo cindido, esse homem está associado aos pequenos. Esse gosto por optar não por animais de médio ou grande porte e sim por aqueles pequeninos, revela-se nos primeiros versos do livro, nos quais são evocados os insetos e o silêncio:

Retrato do artista quando coisa: borboletas

Já trocam as árvores por mim.

Insetos me desempenham.

Já posso amar as moscas como a mim mesmo.

Os silêncios me praticam. [...]. [RAQC - 11].

Joelice Barbosa ${ }^{44}$ notou o parentesco de Virgínia, do romance $O$ lustre, de Clarice Lispector, com Gregor Samsa, nos momentos em que se debate em sua nova forma:

Vestia-se com tanto cuidado como se fosse encontrar uma multidão esperando à porta. Saía à rua, andava lentamente pelo passeio mostrando-se, os olhos atentos, a sensação de que fulgurava ardente, séria. Era um duro inseto, um escaravelho, voava em linhas súbitas, batia de encontro às vidraças cantando com estridência.

\footnotetext{
43 Antonio Vieira, em "O sermão de Santo Antonio" ou “O sermão aos peixes", depois de afirmar que um único tubarão devora vários peixes pequenos, faz a seguinte crítica: mais justo seria o contrário. Manoel de Barros, no processo de miniaturização desse Tratado..., transforma o tubarão em caranguejo e os peixes, em formigas. O que não ocorre no Sermão do orador português, no texto manoelino acontece: a justiça e a fome, ligadas aos ínfimos, são saciadas.

${ }^{44}$ Joelice é mestranda na PUC - SP e estuda esse texto clariciano. Ela fez essa observação em conversa ocorrida em fevereiro de 2007.
} 
[Lispector, 1999, p.139].

Há borboletas de franjas amarelas e de tarjas vermelhas em $O$ livro das ignorãças, já em O lustre há a borboleta branca [Lispector, 1999, p. 259]. Naquele escrito manoelino, é feito um jogo do claro e escuro, no qual aparece um vagalume: $O$ ocaso me ampliou para formiga./ A luz de um vagalume se reslumbra./ [...]. O infinito do escuro me perena. [LI - 59].

Em O guardador de águas, lê-se: Escrever nem uma coisa/ Nem outra - / a fim de dizer todas - /Ou, pelo menos, nenhumas. Assim,/ ao poeta faz bem/ Desexplicar -/ Tanto quanto escurecer acende os vagalumes. (GA - 46).

O vagalume é inseto que, com seu corpo, alterna luminosidade e escureza, por isso ele é muito importante em $O$ lustre, com seus vagalumes violáceos [Lispector, 1999, p. 214] e com essa passagem que é digna de nota:

Eles caminhavam rápidos. Fazia um perfume que dilatava o coração. As sombras iam aos poucos cobrindo o caminho e quando Daniel empurrou o pesado portão do jardim a noite repousava. Os vagalumes abriam pontos lívidos na penumbra. [Lispector, 1999, p. 11].

Carlos Mendes de Sousa, em Clarice Lispector: figuras da escrita, mostra que o escuro às vezes é redimensionado em seu sentido, atingindo positividade no livro, segundo Carlos, pois Clarice aplica a idéia que está contida no seu caderno de notas, correspondente ao período de criação de $O$ lustre, que o crítico cita: A escuridão significava mais do que a ausência de luz. Escuridão era uma concentração e o desabrochamento sombrio de novos elementos mais leves e mais profundos. No escuro as coisas deslizavam enfim na sua própria natureza. Enquanto a luz parecia violentá-las e forçava-as a um ritmo [Arquivo de Clarice Lispector-FCRB, apud: Gomes, 2000, 183].

Mas se há o escuro, com sentidos positivos e negativos, existe também o claro nessa obra clariciana, pois a cor branca é muito reiterada e, em geral, está associada ao silêncio:

Deitava e puxava os lençóis brancos na escuridão vinha o momento quieto antes do sono como se ela caísse então no seu verdadeiro estado. [Lispector, p. $112]$. 
Os outros dias eram uma grande pausa branca. [Lispector, p. 147].

Só de branco adquiria um tom citadino e como o sentisse preferia essa cor para seu melhor trajo. [Lispector, p. 147].

Paredes brancas e velhas imersas na sombra e no silêncio, as janelas piscando iluminadas. [Lispector, p. 248].

O silêncio branco, de Lispector, dialoga com o do conto homônimo de Jack London, comentado no primeiro capítulo desta tese, inclusive porque a autora traduziu esse escritor. A quietez alva lispectoriana, no entanto, não se relaciona à neve, como no caso do texto do autor norte-americano.

O branco é pano de fundo para a capa da quarta edição de O lustre, elaborada pela Editora Paz e Terra.

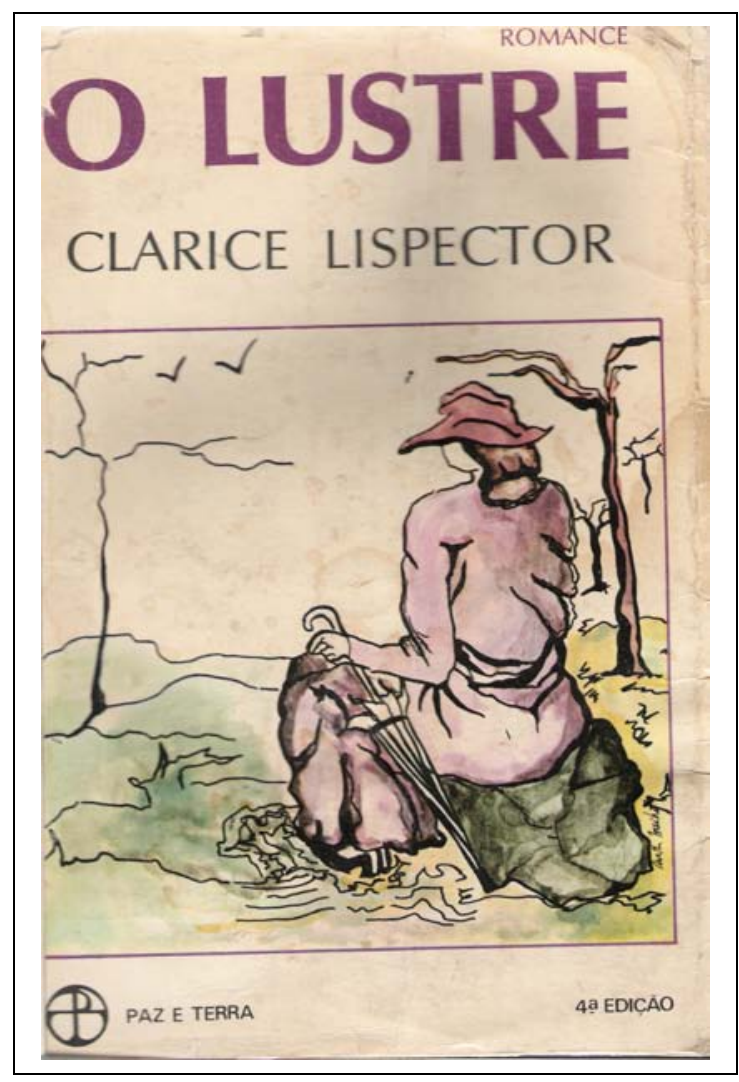

O título aparece em lilás e há árvores secas, uma pedra e dois pássaros 
com asas longas, que podem ser gaivotas ou urubus, o que não é difícil de aceitar, já que a morte é um tema recorrente ao longo do romance.

Essa capa, com apelo para a luminosidade, é uma reelaboração daquela da primeira edição, da Editora Agir. Há três cores: o preto, o verde e provavelmente o branco, que hoje é bege no volume que manuseei ${ }^{45}$.

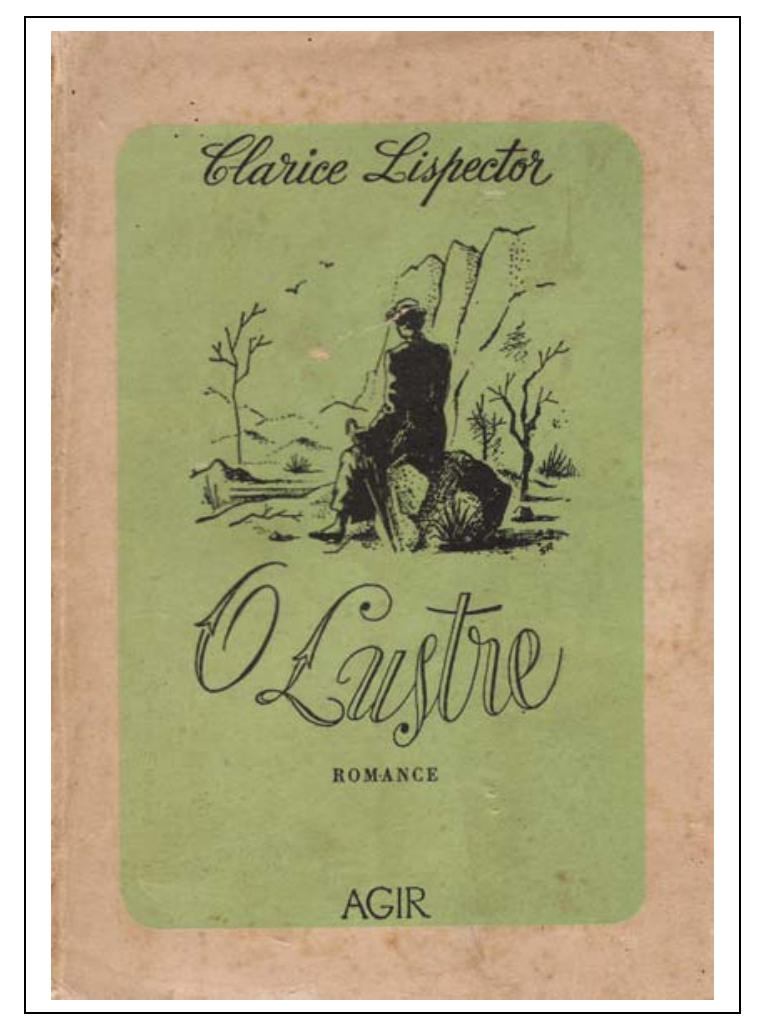

Vê-se uma mulher de costas, como os retratados de Magritte e como o artista quando coisa de Barros. Aparecem também a secura das árvores e a ambigüidade dos pássaros [urubus ou gaivotas] que foram mantidas na quarta edição.

Na Sociedade das Sombras as então crianças Virgínia e Daniel criam a Sociedade das Sombras, na qual falavam uma língua obscura e compreensível apenas para eles mesmos.

A referência a uma linguagem silentemente hermética está presente em Arranjos para assobio:

- Difícil de entender, me dizem, é sua poesia;

o senhor concorda?

- Para entender nós temos dois caminhos: o da sensibilidade,

45 Agradeço a Joelice Barbosa por me emprestar a raridade. 
que é o entendimento do corpo; $e$ o da inteligência que é o entendimento do espírito.

Eu escrevo com o corpo

Poesia não é para compreender, mas para incorporar

Entender é parede; procure ser uma árvore.[AA - 37].

Eu escrevo com o corpo. Essas palavras são do sujeito poético de Arranjos..., mas também são do narrador Rodrigo SM, de $A$ hora da estrela. Aqui, está presente o silêncio das entrelinhas, já que nem a escritora nem sua obra são mencionadas. O leitor deve estar atento ao silentes diálogos entre a escrita de Manoel e a dessa autora.

Esse livro é um silêncio, afirma Rodrigo SM e, referindo-se a Macabéa, diz que ela é quase muda. A protagonista clariciana em sua condição miserável, depois de perder o namorado, decide consultar uma cartomante. No caminho, percebe uma grama rala como ela:

O apartamento térreo ficava na esquina de um beco $e$ entre as pedras do chão crescia capim - e ela o notou porque sempre notava o que era pequeno $e$ insignificante. ${ }^{46}$

Macabéa depois da consulta com Madama Carlota é atropelada e morre olhando a grama pequena e insignificante. Como $\mathrm{GH}$, a alagoana se vê espelhada no que mira.

O sujeito poético de Arranjos para assobio afirma que escreve com o corpo e pede ao leitor que se aproxime da árvore, servindo-se de um entendimento físico do seu texto, rechaçando o raciocínio demasiado que empareda. Há aqui uma proposta anticartesiana, na qual o homem compreende mais suspendendo sua racionalidade e se aproximando de um jeito de mirar e sentir do reino vegetal. Para alguns, isso seria uma involução.

Em Clarice, também, há um desejo de avançar para o começo, como se pode notar em um trecho de A maçã no escuro, em que Martin, num recuo, sente-se cada vez mais próximo a um macaco, antes da transformação em homem.

Van Gogh também era afeito ao recuo, procurando a inarticulabilidade

$\overline{46}$ Lispector, Clarice. A hora da estrela, p. 72. 
pré-verbal na pintura, como mostra George Steiner, no seu ensaio "O repúdio à palavra". O crítico observa que os pintores modernos estão muito mais próximos do silêncio do que os realistas, fundamentados na palavra: $\mathrm{Na}$ pintura e na escultura, o realismo [...] corresponde àquele período em que a língua está no centro da vida intelectual e emotiva. [...]. Exatamente contra essa equivalência ou concordância verbal é que a arte moderna se rebelou. [...]. Van Gogh afirmou que o pintor retrata, não aquilo que vê, mas o que sente. Aquilo que se vê pode ser transposto em palavras; aquilo que se sente pode ocorrer em um nível anterior à linguagem ou fora dela.

"Os corvos sobre campos de trigo", do pintor holandês, que, como se viu, aparece no filme "Sonhos", de Kurosawa, surge também na capa da nona edição de $O$ lustre, publicada pela Francisco Alves.

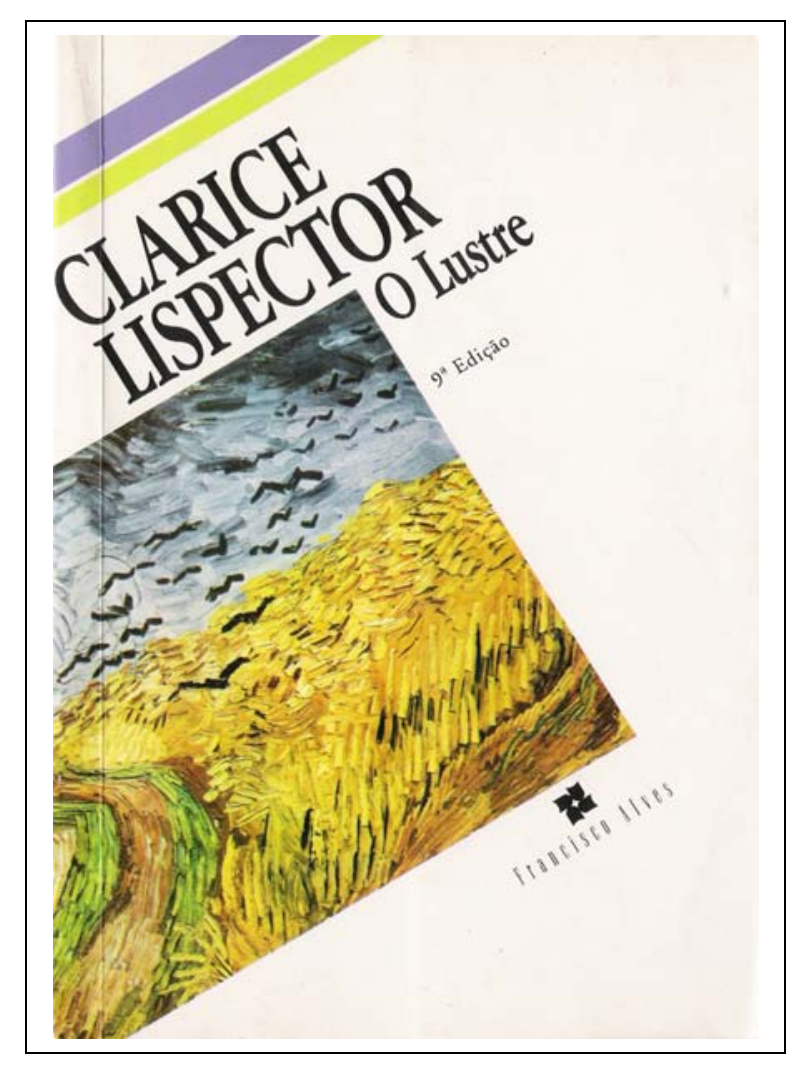

Além dos insetos, $O$ lustre está pleno de mutismos polissêmicos, pois há o silêncio pesado de mormaço [Lispector, 1999, p.11], impalpável [Lispector, 1999, 71], recolhido e atento [Lispector, 1999, p. 119], flutuante [Lispector, 
1999, p. 176], espesso [Lispector, 1999, 186], sorridente ${ }^{47}$ [Lispector, 1999, p. 237].

Barros é um apreciador dos mutismos dos livros de Clarice; só não gostou de um silêncio partido da pessoa Clarice. Em uma entrevista a José Castello, o poeta indica os autores que admira, em seguida vem a pergunta: Você não inclui Clarice Lispector nessa lista? A resposta é esta:

É claro que sim, como ela me escapou? Um dia, escrevi uma carta para a Clarice e ela nunca me respondeu. É uma coisa que me frustrou muito. Abri meu verbo, entreguei meu coração, e nada. Ela só me deu o silêncio. Até hoje dói.

Os críticos também deram o silêncio para $O$ lustre, mas seu brilho é inegável, como mostra a leitura sensível de Carlos Mendes de Sousa, em 2000. Esse livro precisou de muito tempo para que fossem percebidas suas qualidades.

A obra de Barros também demorou para ser percebida pela maioria dos críticos e pelo grande público leitor, mas isso não é defeito, parece mais o contrário: a qualidade de uma obra que está à frente de seu tempo.

A hora da estrela teve uma recepção imediata de público e crítica. Nessa obra, é mostrado que Macabéa mastigava papel bem mastigadinho, pensando ser carne de vaca. A protagonista clariciana é parente de Julio, personagem do filme "O anjo exterminador", de Luis Buñuel. Ele come papel, afirmando que fazia isso quando criança, junto com seus amiguinhos. Julio é o mordomo de uma luxuosa casa de um riquíssimo casal que recebe seus amigos numa festa. Todos ficam enigmaticamente presos ao lugar.

\footnotetext{
47 O olhar avesso ao verbo está presente: trocaram um olhar sem palavra, sem sentido traduzível. [Lispector, 1999, p. 213]. Em outro trecho, instaura-se o mutismo para a escuta da própria interioridade: Esmeralda quedava-se pensativa ouvindo seu silêncio sem entender. [Lispector, 1999, p. 219].
} 


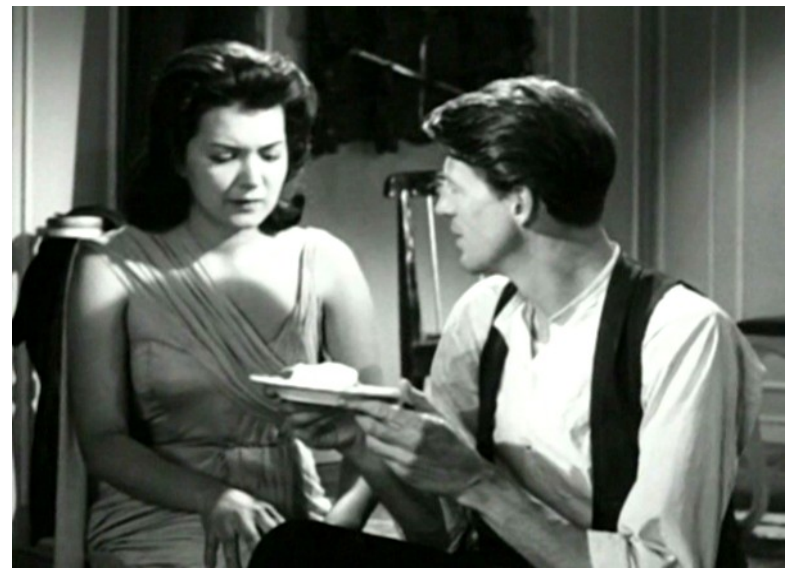

Fotograma de "O anjo exterminador"

Esse e outros filmes de Buñuel serão comparados com os escritos de Barros na próxima seção.

\section{“A EVIDÊNCIA NÃO INTERESSAVA”}

No sonho havia uma rampa mole, o túnel e uma/ lagartixa de rabo cortado./ Pela porta da frente eu não podia sair de/ dentro de mim mesmo com a vida, porque não havia porta da frente./ Lá no alto das nuvem estava deitada a minhal amada, completamente nua./ Eu queria procurar não entender: a evidência/ não interessava como em Buñuel./ Havia um cheiro de verão nas folhas e nas cestas de roupas sujas./ Comecei a catar as ervas 
rasteiras que me arrastavam por analogia./ $O$ vento se harpava em minhas lapelas desatadas./ Eu tinha o roteiro do luar com o mapa da mina./ Depois que todos se deitassem, eu iria passear/ sobre os telhados adormecidos./ Apenas me debatia contudo quanto a lagartixa/ de rabo cortado. [AA - 15].

Enquanto crianças e homens na obra de Barros cortam o rabo das lagartixas, o mesmo ocorre com relação aos lagartos na vida de Luis Buñuel. O cineasta, em sua autobiografia Meu último suspiro, afirma: Um dos grandes acontecimentos da vida de Saragoça foi a exibição do aviador francês Védrines. [...]. Aquilo pouco me interessava. Fiquei apanhando lagartos e cortando-lhes a ponta do rabo, que se agitava ainda um momento entre as pedras. [Buñuel, 1988, p. 38].

Nesse livro, o diretor espanhol apresenta algumas situações de mutismo, como, por exemplo, na sua infância: Meus estudos começaram nos corazonistas, que se chamariam em francês os frades do Sacré-Coeur de Jésus. [...]. Vigilância contínua, ausência de todo contato perigoso entre alunos, e silêncio. Silêncio no estudo e no refeitório, bem como na capela. [Buñuel, 1988, p. 39-40].

Quando adulto, o silêncio ressurge no momento em que Buñuel visita o claustro de El Paular:

Quando trabalhava em El Paular, com Carrière, quase todos os dias às cinco horas, tirávamos um tempo para ir lá meditar. É um claustro gótico, bastante grande. [...]. As tábuas dos postigos estão quebradas e a relva cresce nas paredes. Há um silêncio de antigamente. [...]. Um dia os monges nos convidaram, a Carrière e a mim - morávamos no hotel contíguo -, para almoçar em seu grane refeitório gótico. Foi um almoço bastante bom, com cordeiro e batatas, durante o qual era proibido falar. [Buñuel, 1988, p. 314].

Os espaços misteriosamente silentes atraem o diretor: Adoro as passagens secretas, as bibliotecas que dão para o silêncio, as escadas que se embrenham, os cofres dissimulados (tenho um em minha casa, não digo onde). [Buñuel, 1988, p. 318]. 
A própria sétima arte, segundo Buñuel, pode gerar quietudes: Creio que o cinema exerce um poder hipnótico sobre os espectadores. Basta observar as pessoas que saem de uma sala de cinema, sempre em silêncio, a cabeça baixa $e$ o ar distante. [Buñuel, 1988, p. 95].

O cinema de Buñuel está pleno de silêncios, como aqueles de "Um cão andaluz": o filme é mudo (não há sonorização e a palavra aparece raramente nas poucas legendas), traz imagens (in) quietas (como a do personagem masculino que tem sua boca apagada) e carrega-se de elementos obscuros, não óbvios, confirmando que, para Buñuel, a evidência/ não interessava. [AA - 15].

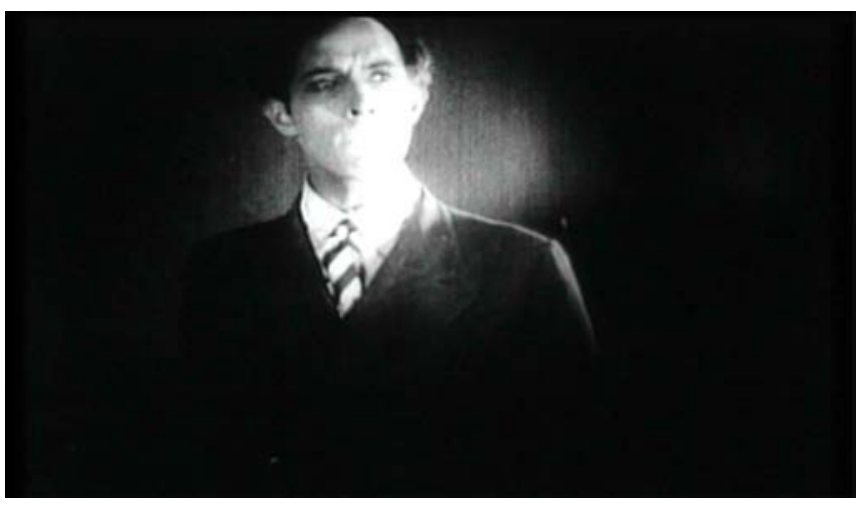

A perda da boca em "Um cão andaluz".

O horror ao óbvio, a proposta de sobreposição de imagens e a busca de atmosferas oníricas (No sonho havia uma rampa mole...), típicas de Luis Buñuel, ainda sob forte influência do Surrealismo, estão no poema manoelino em análise. Inclusive a lua, as nuvens e a mulher nua, presentes em "Um cão andaluz", aparecem no escrito manoelino.
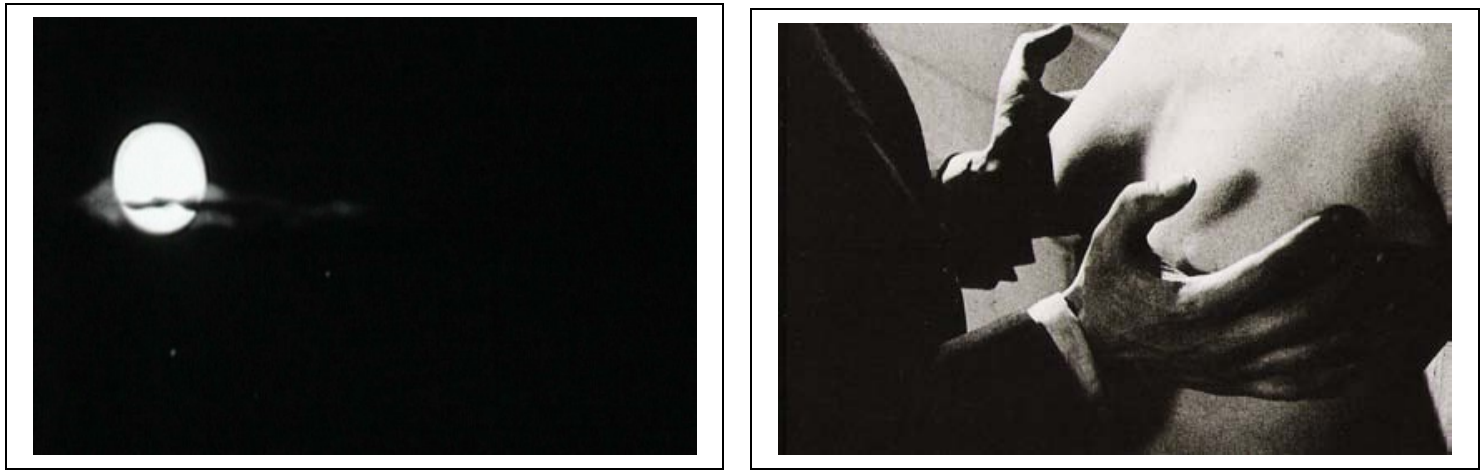

Fotogramas de "Um cão andaluz". 
Nos filmes falados do diretor, que vieram depois de "Um cão andaluz", como nota a estudiosa Erika Savernini, primeiro surge a imagem e posteriormente o verbo, como é o caso do quase-documentário “Terra sem pão" sobre Las Hurdes, região ao norte da Espanha: $O$ comentário do narrador só entra depois que a informação visual foi assimilada pelo espectador, ressaltando fatos escondidos sob a superfície imagética. [...]. Em um dado momento, mostra-se o plano de uma mulher, claramente envelhecida, com uma criança ao colo; passados alguns instantes, o narrador revela que aquela senhora (que o espectador identifica como uma velha) tem apenas trinta $e$ poucos anos. [Savernini, 2004, p. 82-83].

"O diário de uma camareira" parece ser um dos filmes em que os mutismos mais se evidenciam. Logo no início da película, tem-se o silêncio da incomunicabilidade. Celestine, ao chegar à cidade em que vai trabalhar, é recebida por Joseph, que a leva de coche até a casa dos Monteils. Ela diz: $O$ campo é sempre um pouco melancólico. A resposta é o silêncio. Ela tenta mais uma vez: As pessoas não se divertem muito por aqui. A resposta é, novamente, o silêncio.
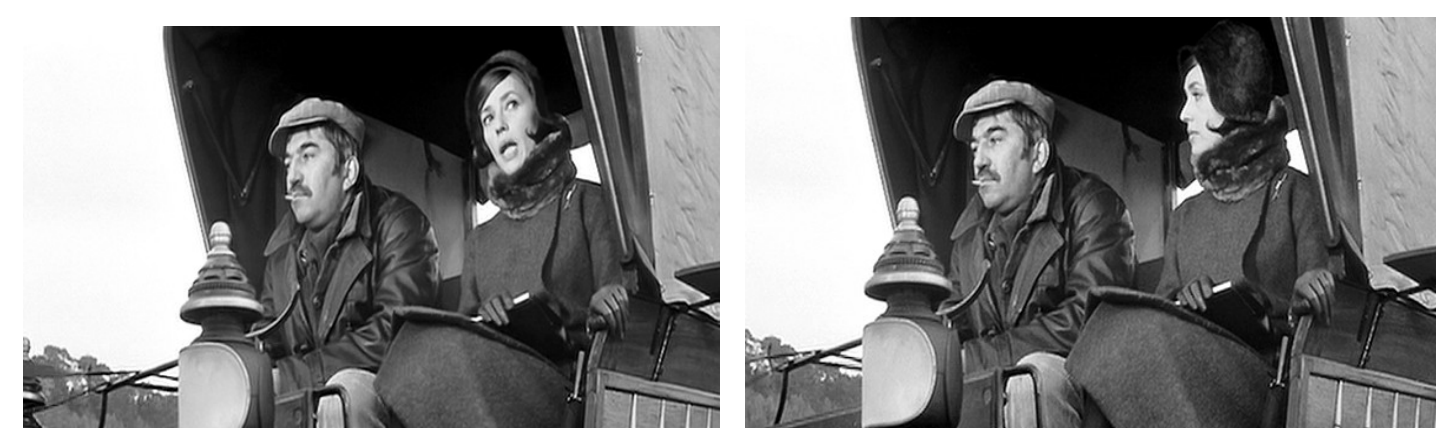

Celestine fala e Joseph emudece.

Em muitas outras situações é a protagonista que emudece. No seu caso, ela quer mirar e ouvir atentamente o que ocorre ao seu redor. Quando acontecem o estupro e o assassinato da pequena Claire, sobrinha de uma das empregadas da casa, Celestine - por ter um olhar e um escutar aguçados - tem quase a certeza de que o autor dos delitos é Joseph.

Num dia, ela interrompeu seu trabalho, por ouvir os doridos ruídos emitidos por um ganso, pego por Joseph. Ela se dirige até ele e diz: Mate! Não o deixe sofrer! A resposta é: São melhores quando sofrem. Eu gosto assim.

Em uma outra situação, Celestine vê uma cena comprometedora: Joseph 
coloca as mãos no pescoço de Claire, como se fosse enforcá-la.
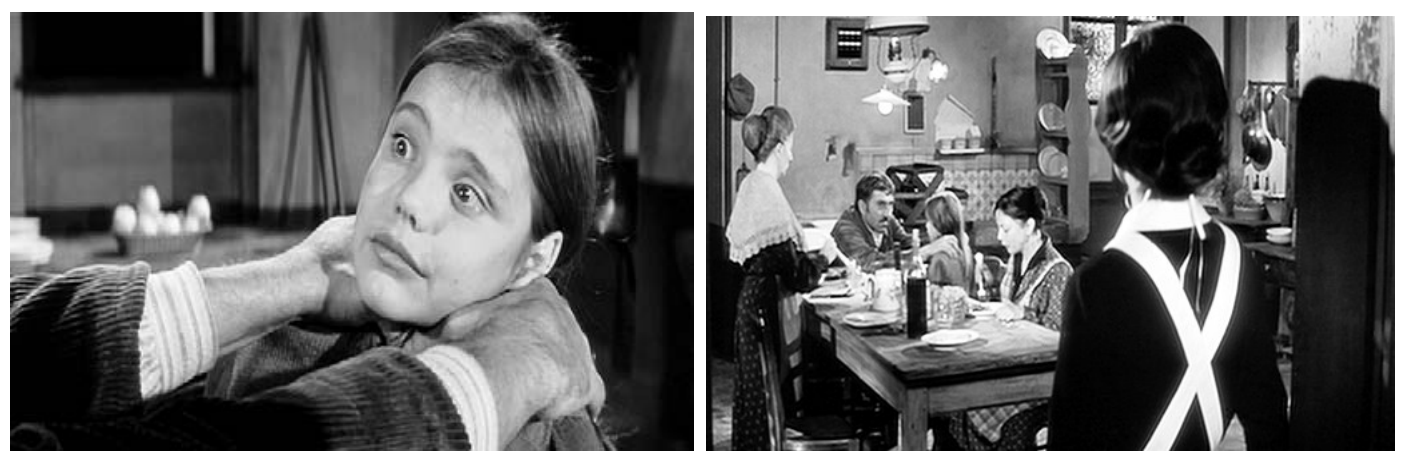

Celestine vê uma situação suspeita protagonizada por Joseph.

Antes de Celestine chegar, Joseph fala para a menina:

- Olhe-me nos olhos. Nos olhos. O que você vê?

- Eu me vejo.

- Isso quer dizer que eu gosto de você. Que penso em você.

É possível que Celestine tenha ouvido essa conversa atrás da porta, pois em uma outra situação ela o fez. A sua patroa a chama e pede que não use perfume; Celestine responde que sim e sai. Em seguida, o marido pergunta à esposa: Você não está exagerando? A resposta é: A garota do ano passado me custou 1500 francos. Esse valor talvez seja correspondente a um aborto, já que Monsieur Monteil já havia engravidado outras camareiras. Ele diz: Querida, uma garota como Celestine, que vem de Paris! Só Deus sabe o que ela fez! As doenças que pegou! E você me acusa...?

Passados alguns dias, Monteil aborda Celestine e ela mostra o quanto tem o ouvido fino: desvencilha-se dele, diz que é uma garota suja, que pegou sífilis e depois o xinga.

O ouvir e o ver de Celestine são requisitados pelo vizinho e inimigo de Monteil, o ex-oficial Mauger, que pede para incriminá-lo no caso de Claire. Mauger costuma jogar lixo na casa do seu adversário. Às vezes, arremessa pedras, como num dia em que acerta o vidro das plantações, no qual passeiam várias formigas. 

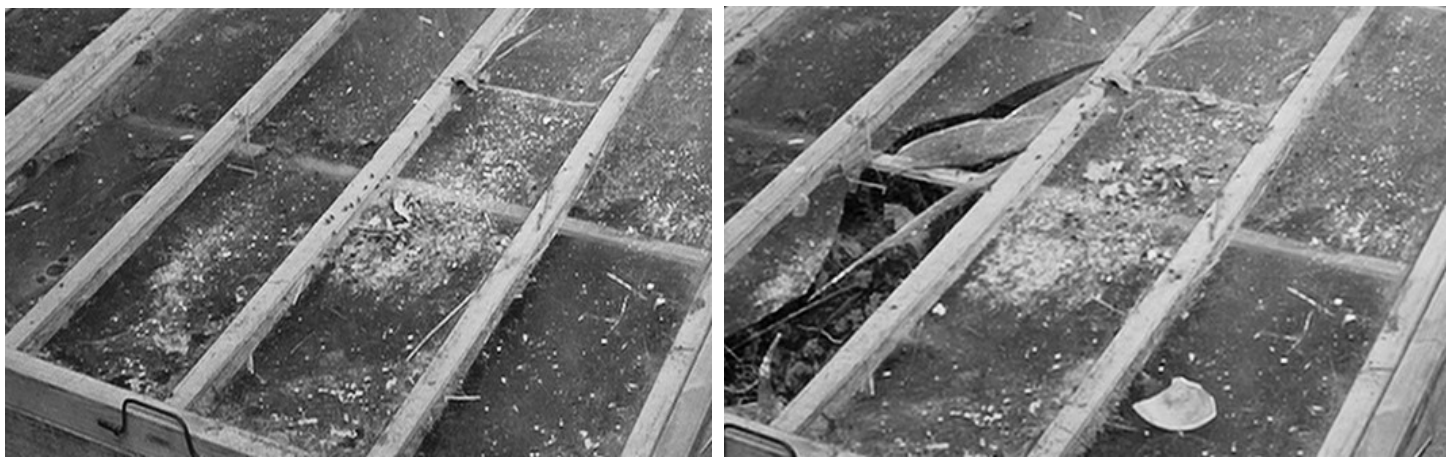

Formigas em meio a brigas de vizinhos.

Os insetos abundam nos filmes do diretor espanhol. Uma abelha aparece em "Viridiana" - um desses pequenos seres é salvo pelo tio da personagem principal, retirando-o da água - e um enxame surge em "Terra sem pão".
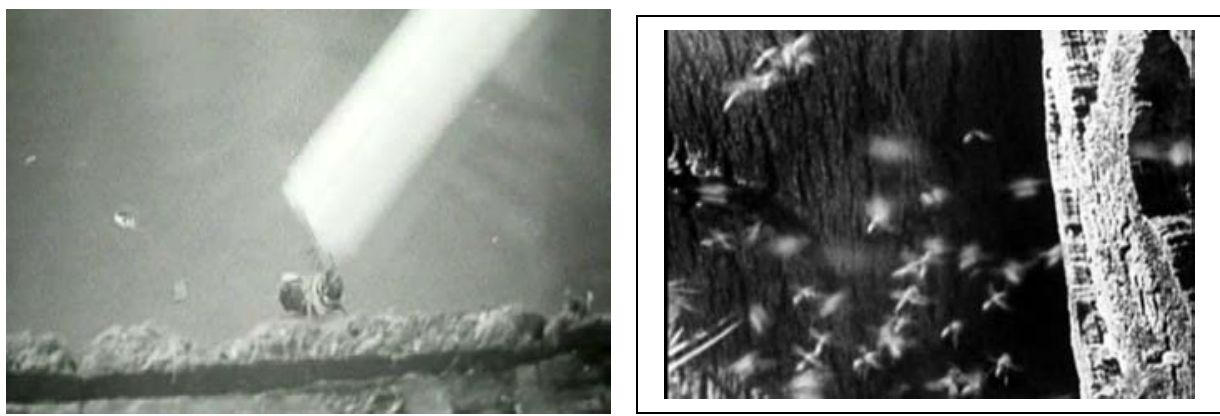

Fotogramas de "Viridiana" e "Terra sem pão".

Em sua autobiografia, Buñuel afirma que teve vários projetos na vida, um deles era o de fazer um filme em que homens comportavam-se como insetos, principalmente como abelhas. [Buñuel, 1988, p. 264].

O pai de Buñuel queria que ele fosse engenheiro agrônomo, então o futuro cineasta, ao cursar a faculdade, pesquisava intensamente esses pequenos animais, o que teve conseqüência para toda a sua vida: Ainda hoje, sou capaz de reconhecer, ao primeiro olhar, numerosos insetos e dar seus nomes latinos. [Buñuel, 1988, p. 73].

Nas cenas finais de "Ensaio de um crime", o protagonista mira um gafanhoto em uma árvore. 

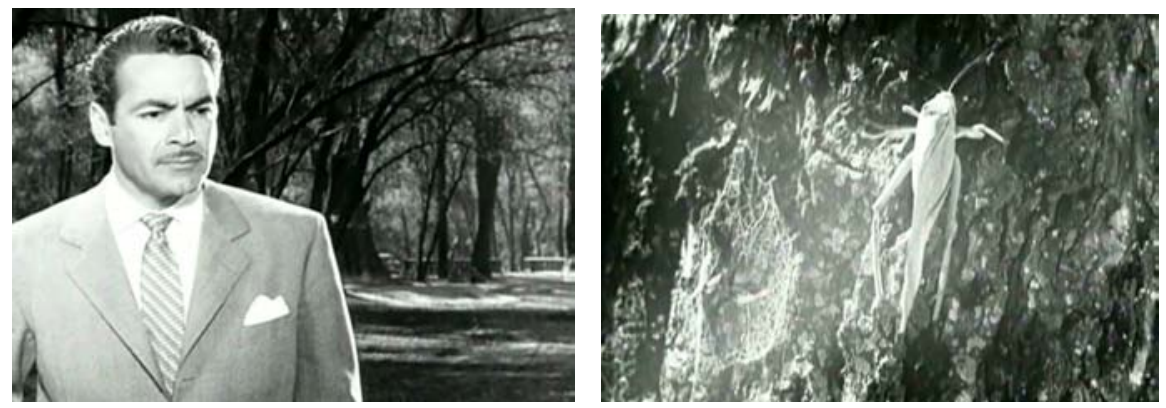

Fotogramas de "Ensaio de um crime".

Em seguida, roça a ponta de sua bengala no bicho. Essa atitude gera tensão em quem assiste ao filme, pois ao longo da história esse homem tentou assassinar várias pessoas. Mas sua reação é confortadora: o animal é deixado com vida e o homem sai sorrindo. Talvez ele tenha se lembrado do que o delegado de polícia disse: ele nunca efetivou nenhum assassinato, apesar de planejá-los.

Em "O discreto charme da burguesia", filme muito apreciado por Fellini, um jovem mantém-se em silêncio, não delatando seus companheiros políticos. Ele é colocado em um piano, que é usado para aplicações de choques elétricos.

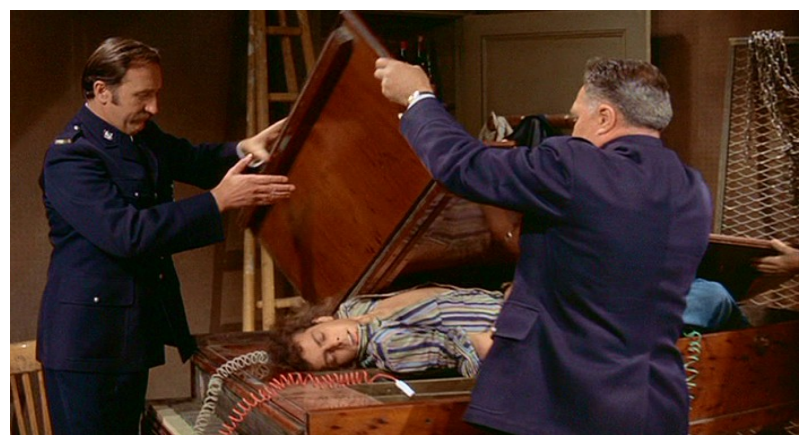

Quando o instrumento é acionado, caem nas suas teclas várias baratas que fogem apressadas.
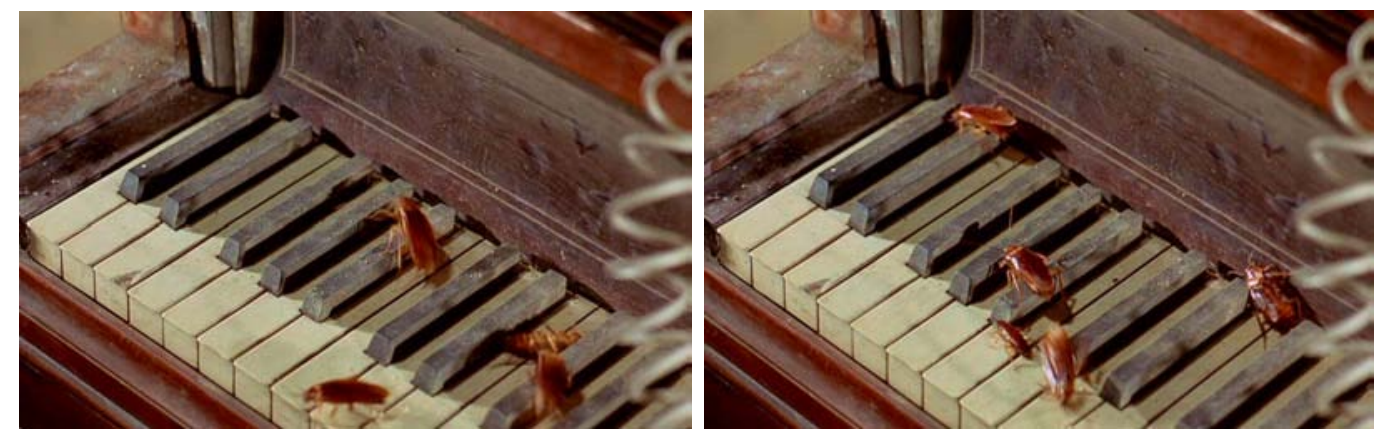

Baratas em "O discreto charme da burguesia". 
As moscas, que, em Arranjos para assobio, carregam rios caudalosos de sentido, estão presentes em "A idade de ouro", de Buñuel

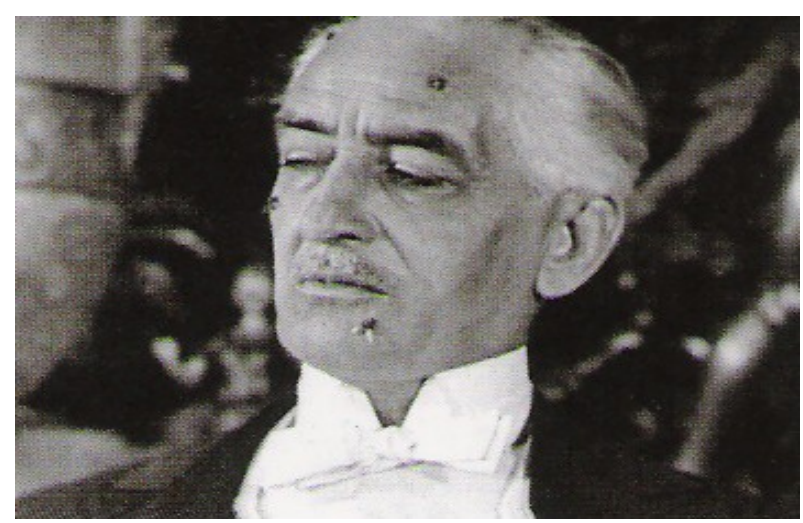

Fotograma de "A idade de ouro", de Buñuel.

Sem legendas, essa cena é muito expressiva, já que pode sugerir o horror de Buñuel à ostentação desse burguês: é como se ele fosse um excremento, algo em putrefação, ou coisa do gênero.

Em uma outra seqüência de "A idade do ouro", um homem esmaga um besouro.
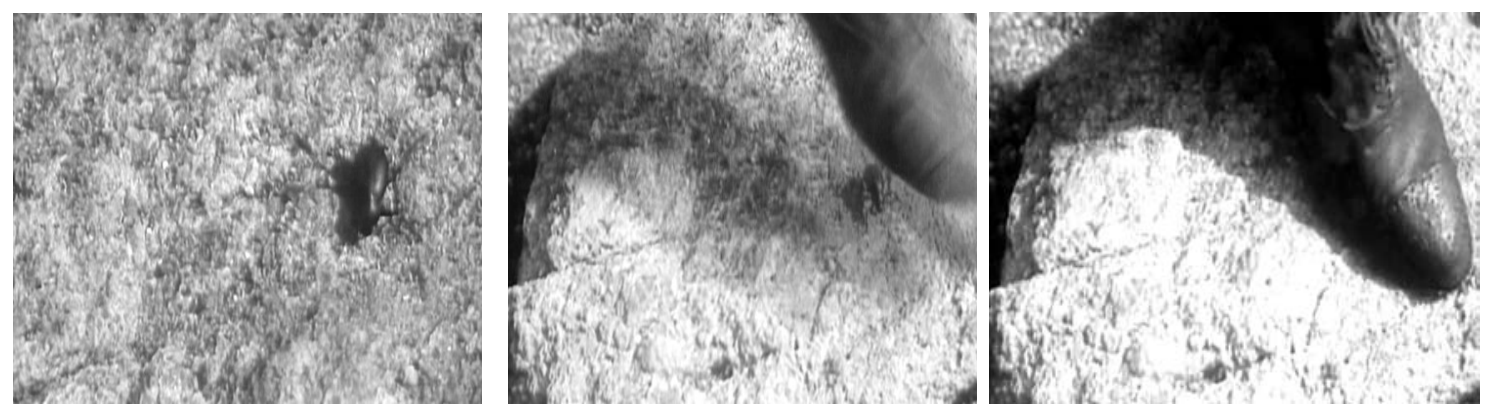

Fotogramas de "A idade do ouro". 
Essa cena está próxima de uma situação de um poema de Arranjos para assobio: Devo ter maltratado com os pés, na minha infância, algum pobrediabo. Pois como explicar/ o olhar ajoelhado desse besouro?).

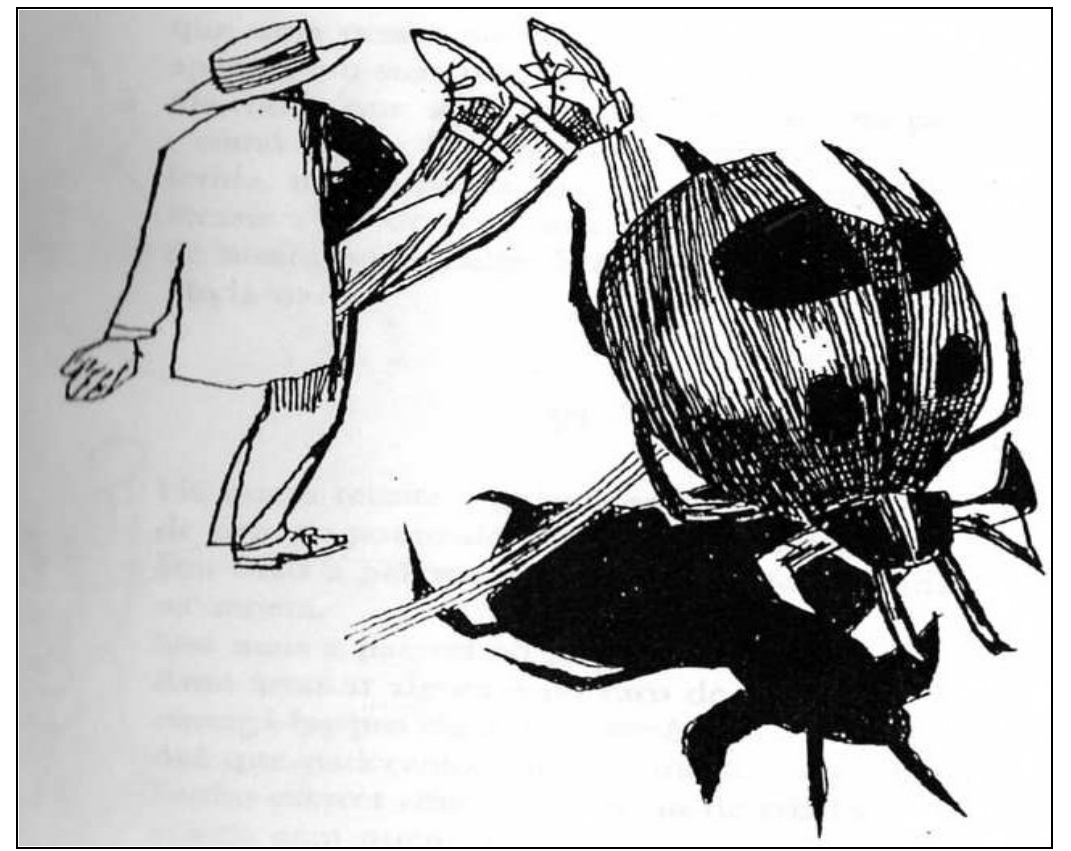

Desenho de Poty para o poema de Manoel de Barros em análise.

Em "A idade do ouro", o esmagamento do besouro é literal e visível aos olhos do espectador, mas tem também um sentido metafórico, pois quem o faz é um "respeitável" homem que em uma cena posterior aparece recebendo um diploma, pleno de orgulho. Então, pés poderosos esmagam entes menores.

No caso do poema manoelino, essa metáfora é também plausível, mas ela é carregada de um tom mais dramático e pleno de dúvidas:

Quando houve o incêndio de latas nos fundos da Intendência, o besouro náfego saiu/ caminhando para alcançar meu sapato (e eu lhe dei um chute?)/ Parou no ralo do bueiro, olhoso como um boi/ que botaram no sangradouro dele/ [Intrigante: não sei de onde veio nem de que lado de mim entrou esse besouro. Devo ter maltratado com os pés, na minha infância, algum pobre-diabo. Pois como explicar/ o olhar ajoelhado desse besouro?

Não há o esmagamento, como no filme de Buñuel, ocorre um chute, do qual o besouro sobrevive, mesmo que náfego. O olhar ajoelhado do besouro 
gera questionamentos em quem o chutou, já que quer entender o porquê do mirar genuflexo.

Em "Simão no deserto" e "Robson Crusoé", insetos são colocados na mão para serem melhor observados. O homem ignora o nome deles.

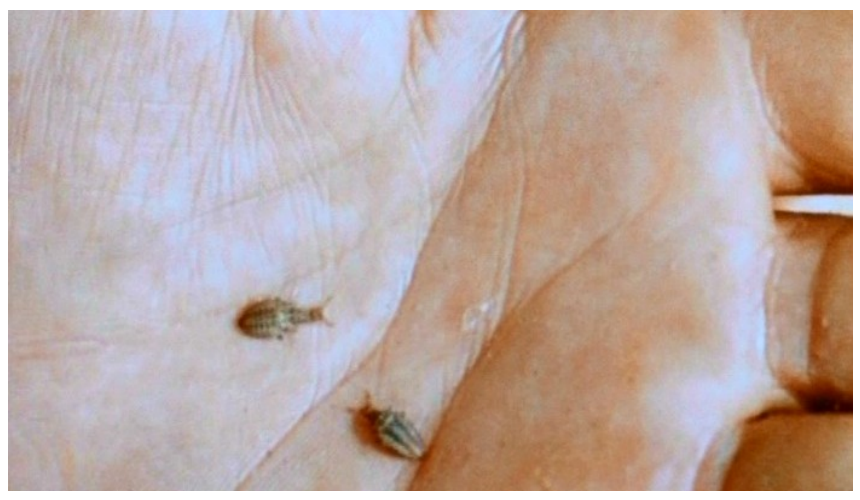

Fotograma de “Robison Crusoé

$\mathrm{O}$ ato de mirar insetos está presente desde seu primeiro filme, "Um cão andaluz", cujo roteiro é também de Salvador Dali.
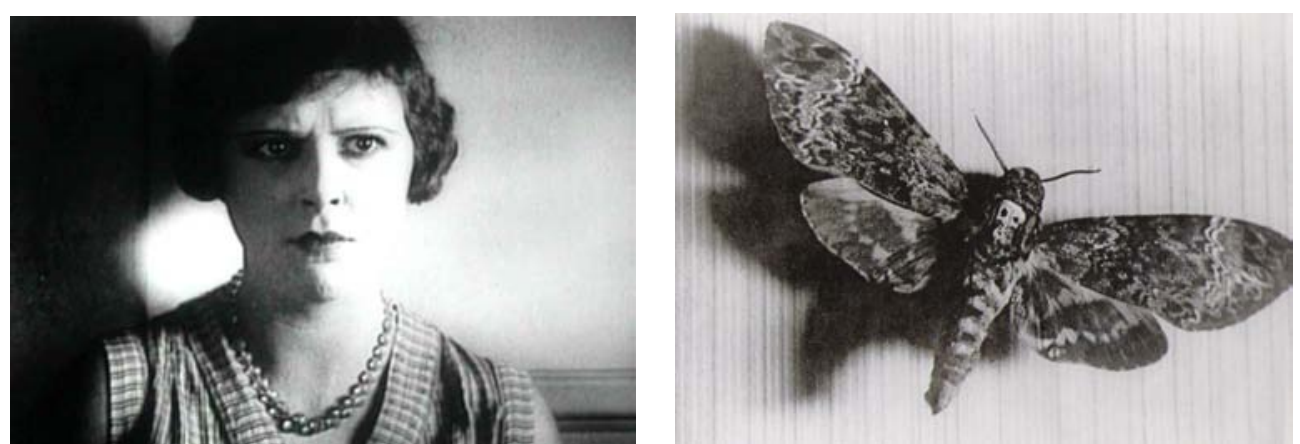

Fotogramas de "Um cão andaluz"

Essa imagem torna-se um enigma, pelo efeito da sobreposição: tem-se, ao mesmo tempo, uma mariposa e um crânio de cachorro. Os buracos em que estariam os olhos do cachorro estão na direção da mulher que o olha.

A mariposa aparece pequena e depois cresce aos olhos da observadora. 

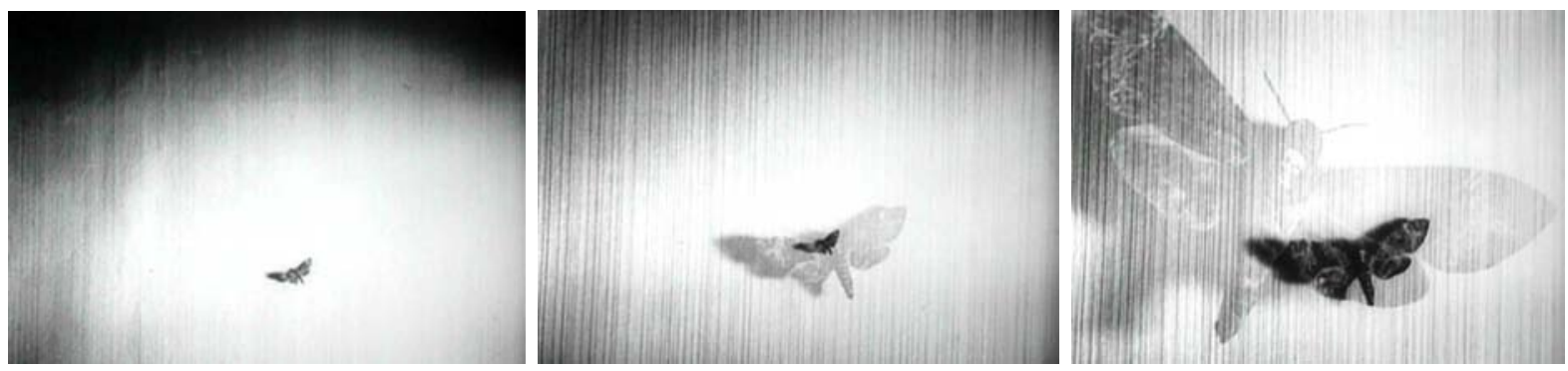

Fotogramas de "Um cão andaluz".

O efeito zoom é usado.
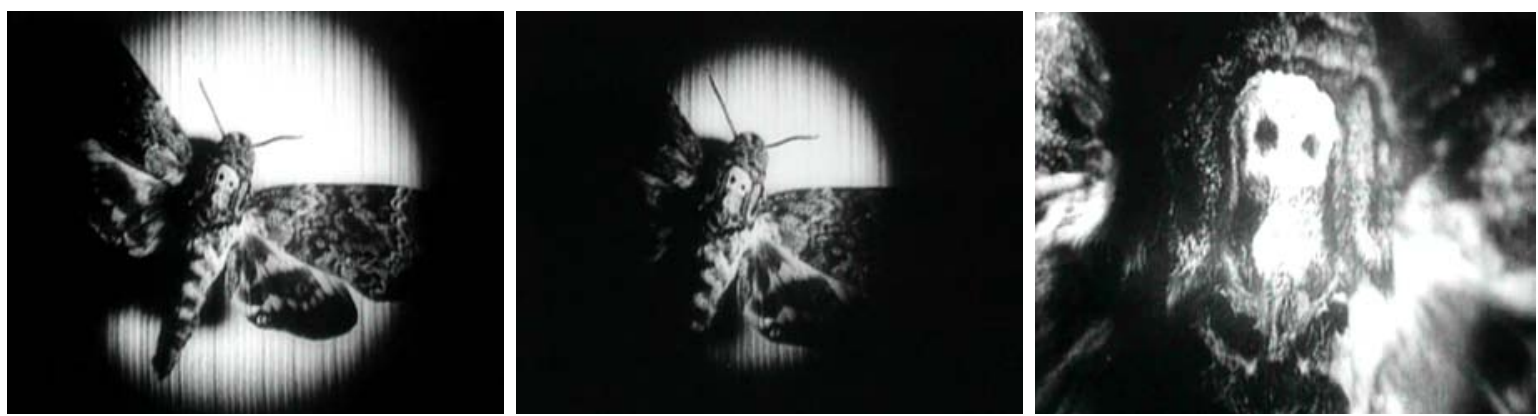

Fotogramas de "Um cão andaluz".

Em outra seqüência dessa película, as formigas, tão abundantes nas obras manoelinas, aparecem.
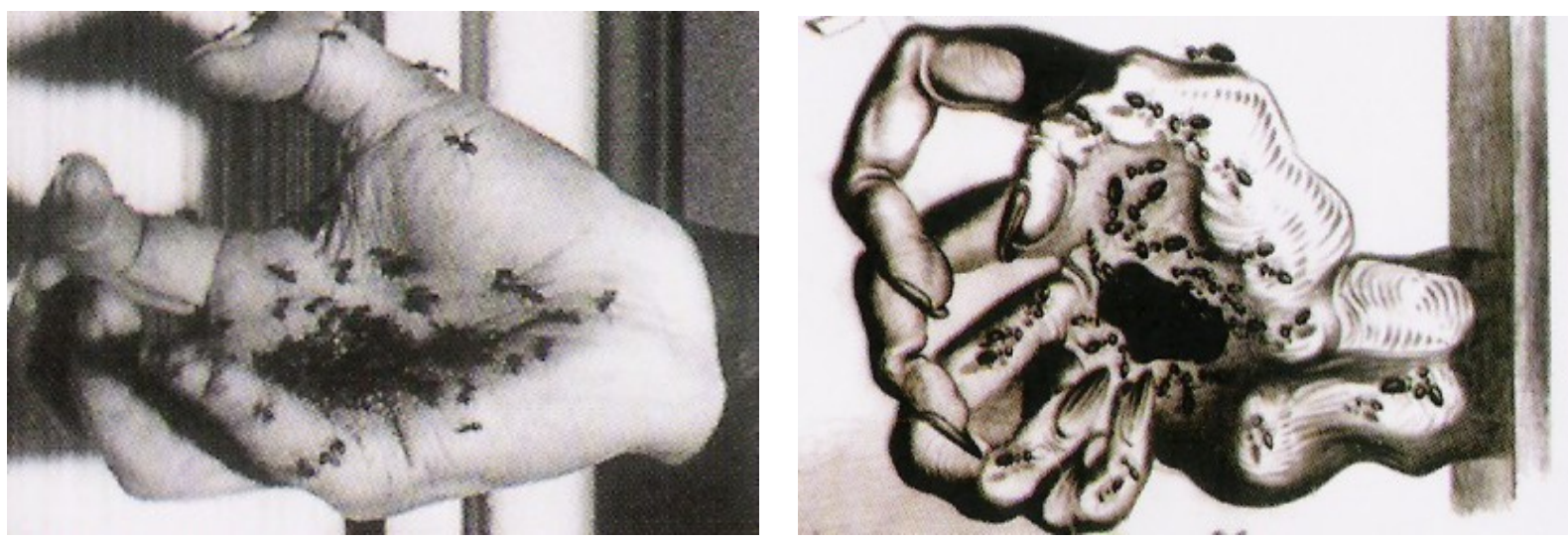

Fotograma do filme “Um cão andaluz" e desenho de Salvador Dali ${ }^{48}$.

Em Arranjos para assobio, a formiga surge num contexto inusitado, como no filme dos dois artistas espanhóis:

- E o poema é seus fragmentos?

- É muito complicado dar ossos à água. Passei

48 Salvador Dali espalhou formigas por várias de suas obras, como no célebre quadro "A persistência da lembrança" e também num desenho cuja imagem acabou sendo incorporada no roteiro de "Um cão andaluz". 
anos enganchado num pedaço de serrote, na beira do Rio Coxim. Veio uma formiguinha de tamanho médio, me carregar. Eu ia aos trancos como mala de louco. E não podia entender a razão pela qual aquela formiguinha, me carregando, não evitava os barrancos, os buracos, os abismos/ Me carregava obstinada para o seu formigueiro/ Ia comer o meu escroto!/ Nossa grandeza tem muito cisco.

Em "Diário de uma camareira", Rabour gosta de fustigar os pequenos, como borboletas e abelha, que são alvo de seus primeiros tiros.
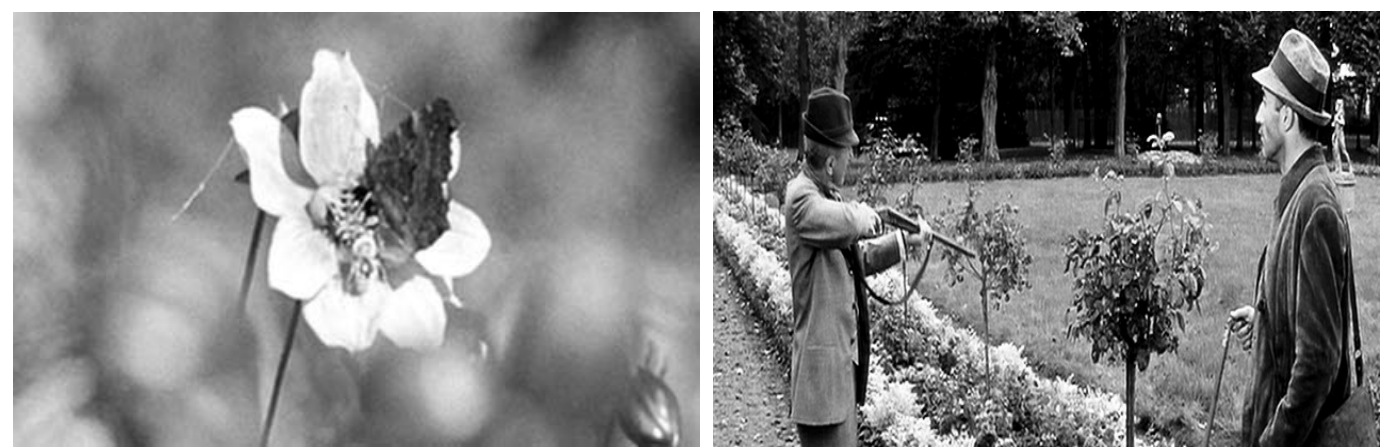

Abelha e borboleta são alvos de Rabour, aprendendo a atirar com seu genro.

Nesse filme, as máscaras e as vazias convenções da burguesia são alvo de ataque da poesia cinematográfica de Buñuel. Celestine sai de Paris e vai para uma área rural da França, para trabalhar numa casa de ricos. Lá, deparase com o luxo material e com a miséria anímica dos seus patrões: um casal com problemas de cunho sexual: ela é frígida e ele, impotente com relação à esposa, mas muito viril com relação a outras mulheres. O pai de sua patroa é fetichista e pede para Celestine calçar uma bota preta e desfilar para ele. Nessa seqüência, a camareira quase não fala, mas seu rosto diz muito: ela ri silenciosamente, olha para cima, franze a boca, o que faz com que aquele que assiste ao filme note o quanto ela acha ridículo e entediante aquele universo. 

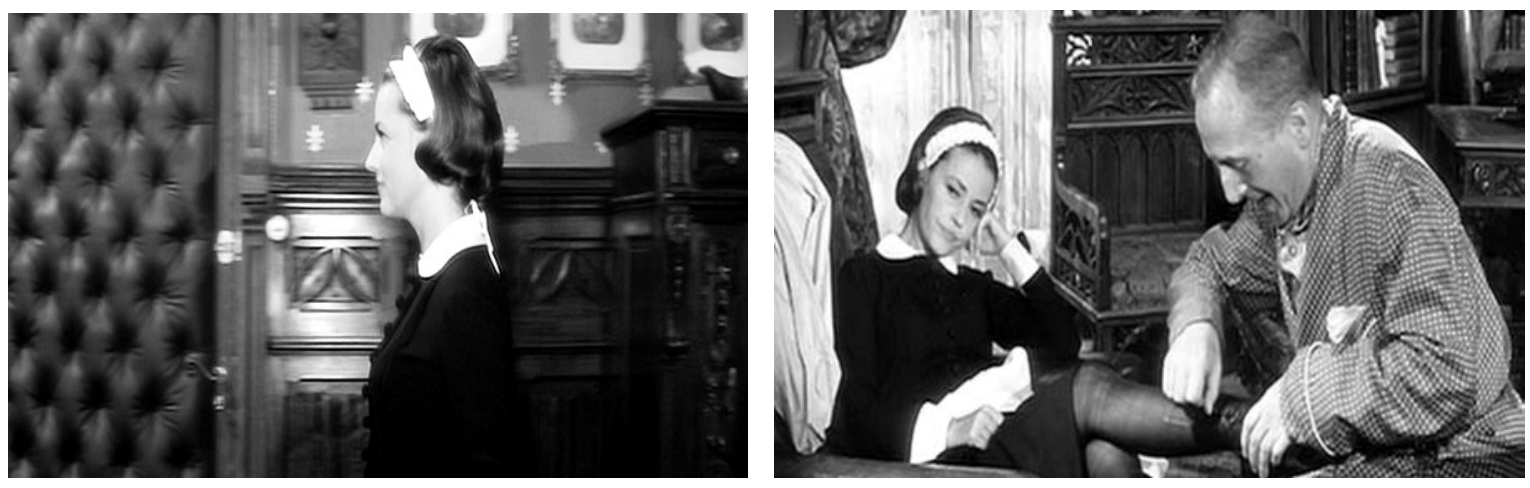

Silenciosas e eloqüentes reações de Celestine, em "O diário de uma camareira".

Esse filme, de 1964, mostra também o mutismo da escuta diante da leitura: Rabour pede a Celestine que leia para ele: Tem noites que estou cansado e gosto que leiam para mim. É agradável ouvir uma voz bonita. Você conhece Huysmans? [...]. Um grande escritor. Eu gosto muito dele.

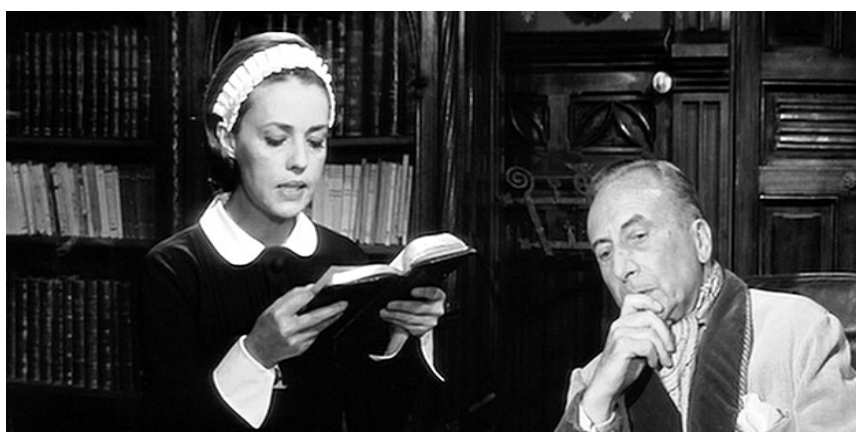

Celestine lê Huysmans para o pai de sua patroa.

A camareira aprecia ler, tanto que em uma noite, ao servir um chá, ela tenta ver o que está escrito num livro aberto, mas se depara com o olhar de ferro [Nassar, 1995, p. 80] de Rabour, parecido com aquele de Um copo de cólera, de Raduan Nassar, comentado no primeiro capítulo desta tese.
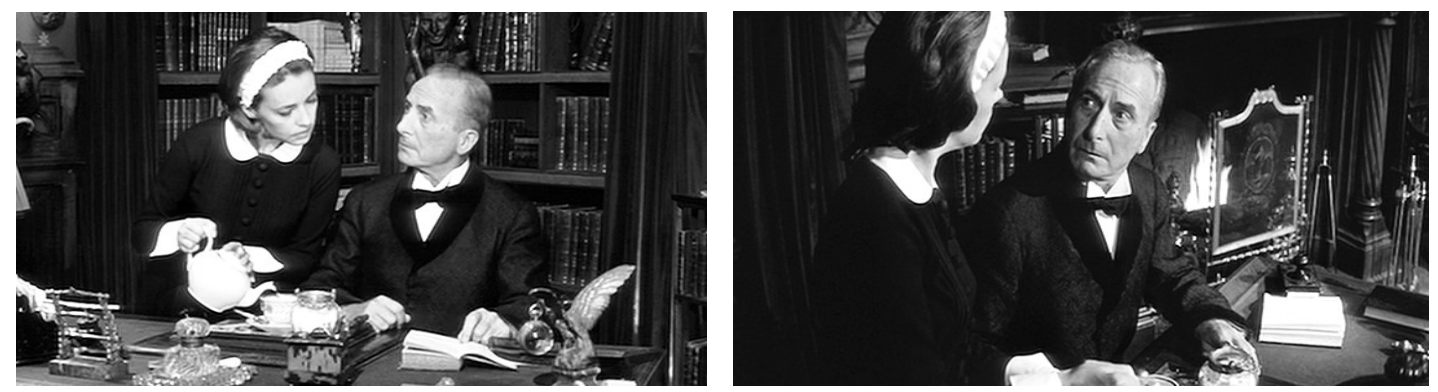
Olhares com sentidos diversos em "Diário de uma camareira".

Parece que, nesse caso, Buñuel, no silêncio da sutileza, sugere que o enricado homem, em seu ensimesmamento, só aprecia a leitura de Celestine feita para ele e não para ela própria, já que, inclusive, fecha o livro.

No filme, ocorre a desnomeação como mostra de poder: Rabour diz que chamará Celestine de Marie, porque é mais curto. Assim, os apequenados têm que ter um nome condizente com a sua dimensão social.

O assassinato de Claire se dá num bosque; sua roupa se parece com a de chapeuzinho vermelho - se bem que puída como a indumentária de Akaki Akakievitch - e ela porta um cesto cheio de caracóis. Quando Joseph a encontra diz a ela: Cuidado com o lobo!
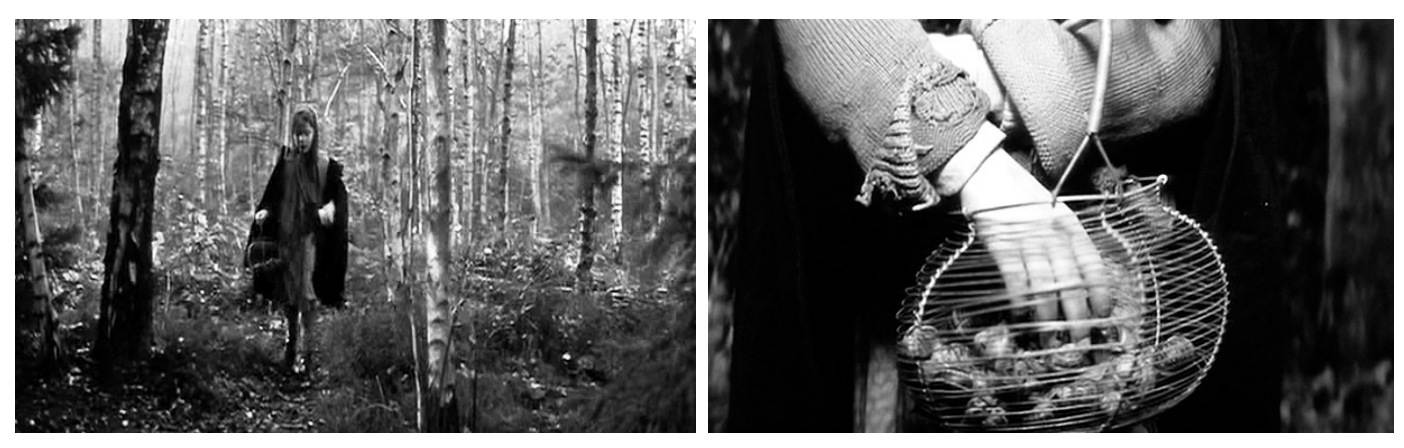

A imagem da menina assassinada é elaborada. A câmera se movimenta no escuro do bosque até chegar ao cesto caído, as botas e as pernas da garota, em que se vêem dois caracóis. Então, tem-se um zoom.
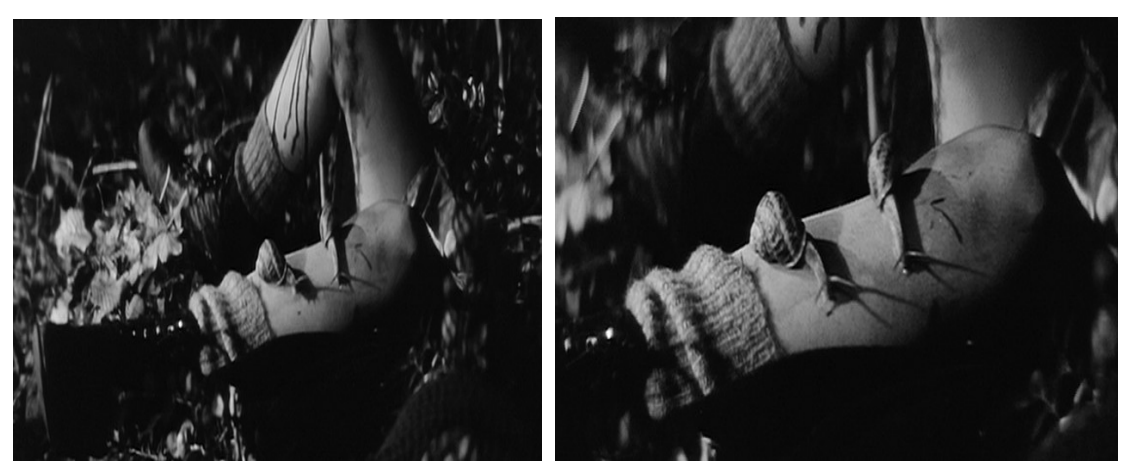

Fotogramas de "O diário de uma camareira".

A vida de um caracol associada a um contexto de morte de um ser humano está nesse filme e no poema "O morto - I", de Manoel de Barros, do 
livro Poesias: À noite enterrou-se/ O homem/ Na raiz de um muro / Com sua roupa no corpo./ E a chuva regou no horto/ Desse vitorioso/ Homem morto/ enormes violetas/ E uns caramujos férteis... [P, in: PQT - 107].

Mas existe uma diferença entre os dois contextos: o escrito manoelino tem uma conotação mítica que não aparece na película de Buñuel: o colorido das violetas e a fertilidade dos caramujos garantem continuidade ao que seria finitude.

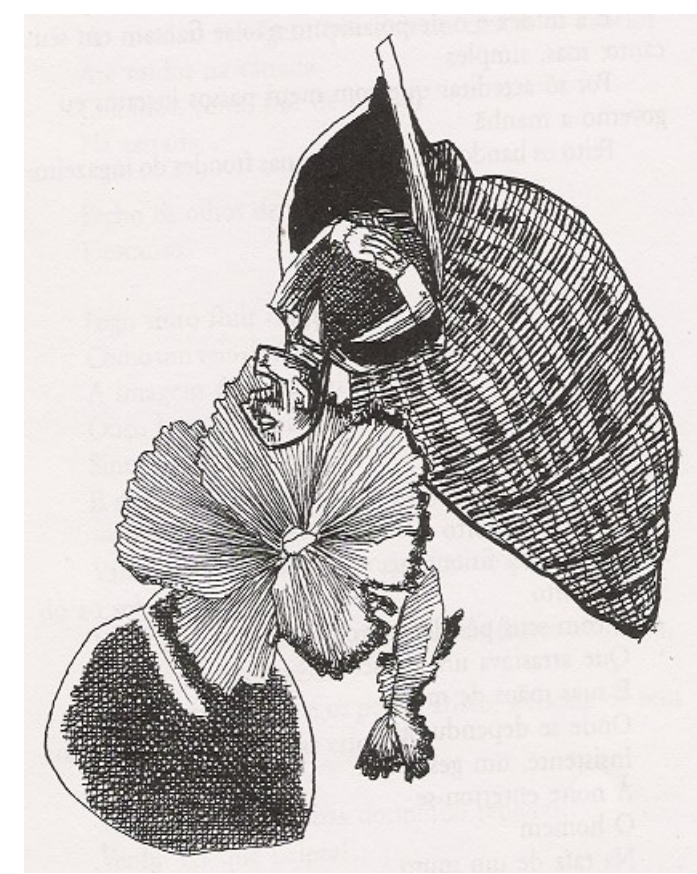

Ilustração de Poty para o poema "O morto - I", do livro Poesias, in: PQT.

O filme de Buñuel tem uma atmosfera mais realista e talvez desencantada: ao final, o provável assassino de Claire está solto, casado com uma bela mulher e tem um café.

O ceticismo é marca de muitas películas do cineasta espanhol; em muitas histórias rodadas por ele, no silêncio da sutileza, o que se pode apreender é que ninguém é mais confiável, nem ricos, nem pobres, como em "Viridiana".

Descrer nas pessoas e em Deus é a tônica de vários de seus filmes, como em "A via Láctea". Em outros casos, parece existir uma ambigüidade com relação a assuntos místicos, vide "Nazarin". Nessa película, o padre protagonista concorda com os entes manoelinos: Deus está associado à natureza e aos pequenos, por isso pega um caracolzinho e o coloca em sua 
mão, para se amalgamar ao divino.

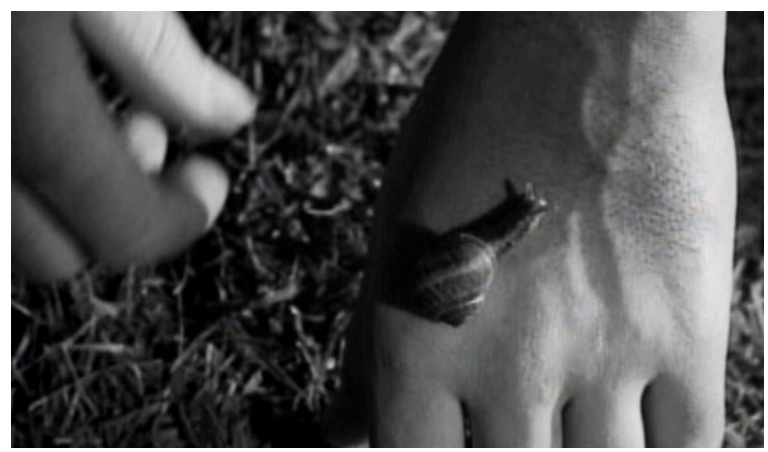

Fotograma de "Nazarin".

Ao final desse filme, quando Nazarin caminha, levado por um policial, ouvem-se sons de tambores de Calanda, lugar em que nasceu Buñuel. O diretor, em relato autobiográfico mostra o quão fino é seu ouvido: Os tambores de Calanda tocam sem interrupção, ou quase assim, do meio dia da sexta-feira santa até o dia seguinte, sábado de aleluia, à mesma hora. [...]. As batidas obedecem a cinco ou seis ritmos diferentes, que não esqueci. [Buñuel, 1988, p. 32].

Em "Nazarin", um anão é chamado carinhosamente de "Caracolzinho"; o mesmo ator aparece também em "Simão no deserto" e, em "Esse obscuro objeto do desejo", surge um outro anão, que é psicólogo.

Gente diminuta é uma constante nos filmes de Buñuel, como as crianças de "Os esquecidos", que por falta de amor dos pais caem na delinqüência. Em uma cena forte dessa película, elas maltratam um pedaço de gente, parecido com o Sabastião de Barros.

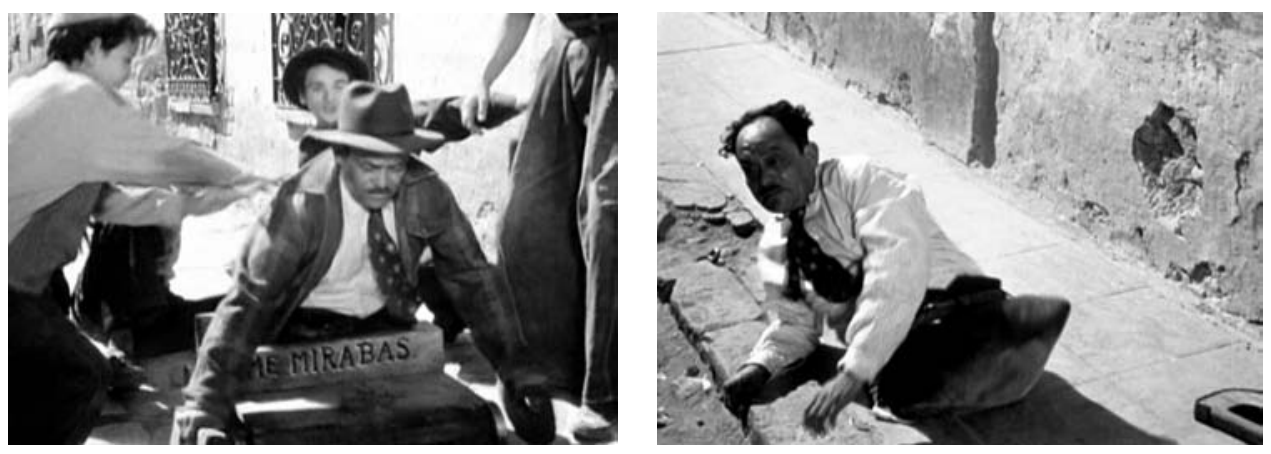

Fotogramas de "Os esquecidos".

Os pequenos estão também em "Terra sem pão", em cujas pernas, que não foram amputadas, pousam moscas, mostrando a condição de estarem 
abandonados à própria sorte.

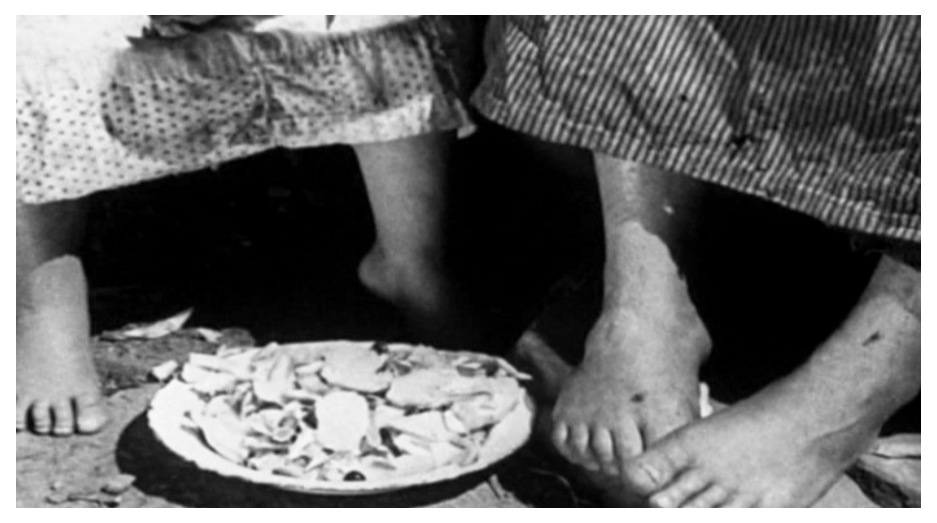

Fotograma de "Terra sem pão".

Além de apresentar os sem sapatos, os sem pernas, os sem amor, Buñuel apresenta também os sem palavras, como o menino que, em "A via láctea", sem reclamar, mostra seu corpo machucado e com gesto e olhar silenciosos e amorosos consegue carona para os dois peregrinos que se dirigem para Santiago de Compostela. 


\section{À GUISA DE DESCONCLUSÃO}

Usar palavras para tentar definir os silêncios. Esse foi o antitético propósito desse trabalho, que se iniciou com as discussões de teóricos e o dizer de escritores a respeito do assunto.

Na seqüência, houve um trânsito no mundo silente dos livros de Manoel de Barros. Retrato do artista quando coisa e Arranjos para assobio foram analisados nos dois derradeiros capítulos.

Em se tratando de Barros, a partir dos mutismos da escuta e do ver, o que parece ressaltar-se em sua obra é a fixação pela despalavra inaugural, pela inarticulabilidade de um mundo em devir, inconcluso.

O erudito e o popular, a música e a pintura, o preto e branco bem como o colorido de películas são instrumentos para tentar alcançar esse horizonte préverbal em sua pujança.

Homens de costas em Barros, Lispector, Buñuel, Kurosawa e Fellini buscam rotas, talvez labirintos. Eles podem encontrar a redenção, a morte, a paixão, a injustiça no caminho, mas é certo que encontrem silêncios.
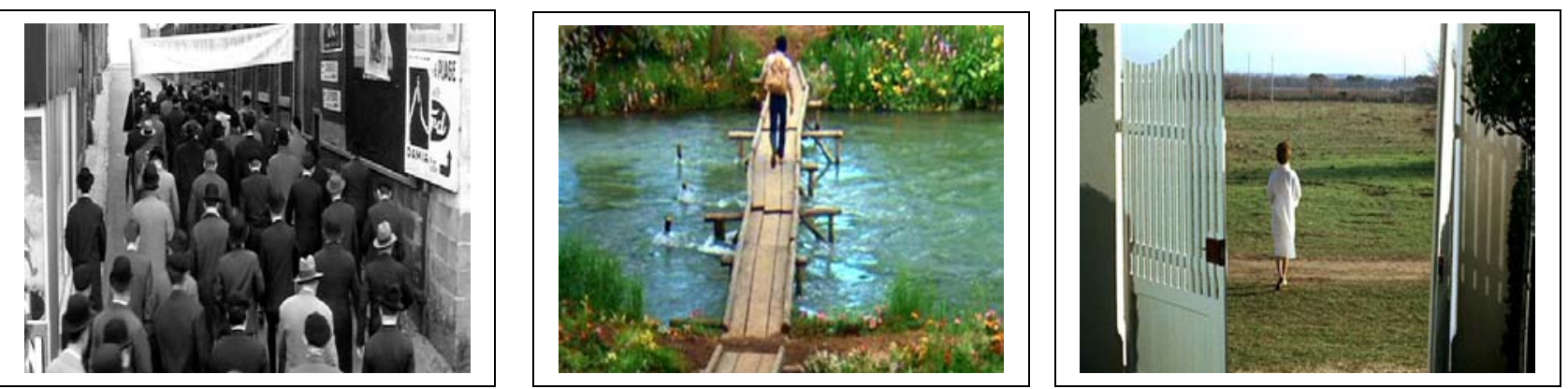

Cenas finais de "O diário de uma camareira", "Sonhos" e "Julieta dos espíritos".

Barros declara seu amor aos mudos pedaços de pessoas, como os entes beckettianos, e, na silente escuta e na quietez do mirar, mostrando a necessidade de sair de si, amalgamando-se de compaixão ao que vê e ao que ouve, principalmente aos que têm voz pequena. 
O escritor cuiabano registra gestos, palavras, mutismos de crianças [como Nina e Vânia, de Anton Tchékhov] e de índios, mostrando que é preciso um recuo para recuperar inocência, viço e liberdade no trato com a linguageminarticulabilidade e com a própria vida. Por isso, um eterno refazer-se é necessário, um constante repensar é requerido no âmbito literário e no contexto cotidiano. Essa parece ser a nossa realidade de inconclusos seres com características hominais e animais, o que é atestado pelo sujeito poético de Matéria de poesia: A gente é que nem rascunho de pássaro/ Não acabaram de fazer...

\section{REFERÊNCIAS BIBLIOGRÁFICAS}

\section{OBRAS DE MANOEL DE BARROS (POR ORDEM DE PUBLICAÇÃO):}

Poemas concebidos sem pecado. Rio de Janeiro: Edição particular, 1937.

Face imóvel. Rio de Janeiro: Editora Século XX, 1942.

Poesias. Rio de Janeiro: Irmãos Pongetti Editores, 1956.

Compêndio para uso dos pássaros. Rio de Janeiro: Livraria São José, 1961.

Gramática expositiva do chão. Rio de Janeiro: Editora Tordos, 1966.

Matéria de poesia. Rio de janeiro: Livraria São José, 1970.

Arranjos para assobio. Rio de Janeiro: Civilização Brasileira, 1982.

Livro de pré-coisas. Rio de Janeiro: Philobiblion Livros de Arte Ltda. e Fundação de Cultura de Mato Grosso do Sul, 1985.

O guardador de águas. São Paulo: Art Editora, 1989. 
Gramática expositiva do chão: poesia quase toda. Rio de Janeiro: Civilização Brasileira, 1990.

Concerto a céu aberto para solos de aves. Rio de Janeiro: Civilização Brasileira, 1991.

O livro das ignorãças. Rio de Janeiro: Civilização Brasileira, 1993

O livro das ignorãças. São Paulo: José Mindlin Editor, 1993.

Livro sobre nada. Rio de Janeiro: Record, 1996

Retrato do artista quando coisa. Rio de Janeiro: Record, 1998

Exercícios de ser criança. Rio de Janeiro: Salamandra, 1999.

Ensaios fotográficos. Rio de Janeiro: Record, 2000.

O fazedor de amanhecer. Rio de Janeiro: Salamandra, 2001.

Tratado geral das grandezas do ínfimo. Rio de Janeiro: Record, 2001.

Poeminhas pescados na fala de João. Rio de Janeiro: Record, 2001

"Fragmentos de canções e poemas". In: Vieira, Ana Thereza. Rotae temporis. [Edição bilingüe português - latim]. Itália: Grilli, 2001

30 segundos. São Paulo: Eraodito Editora, 2002.

Memórias inventadas - a infância. Rio de Janeiro: Planeta, 2003.

Cantigas por um passarinho à toa. Rio de Janeiro: Record, 2003. 
Poemas rupestres. Rio de Janeiro: Record, 2004.

Memórias inventadas - a segunda infância. Rio de Janeiro: Planeta, 2006.

\section{SOBRE OBRA DE MANOEL DE BARROS}

Aguiar, Flávio. "Ali onde nasce a linguagem: bonito é o desnecessário". D. $O$. leitura, Ano 17, número 1, Maio de 1999, 32-34.

Alves, Rogério Eduardo. "Construtor de mitos". Folha de São Paulo. 14 de maio de 2003.

USP, 2005.

. Manoel de Barros, o poeta fazendeiro. Dissertação de Mestrado.

Avelar, José Carlos. Literatur im Brasilianischen film; Brazilian cinema and literature; Cinema e literatura no Brasil. São Paulo: Câmara Brasileira do Livro, 1994.

Béda, Walquíria Gonçalves. O inventário bibliográfico sobre Manoel de Barros. Tese de Doutoramento. UNESP, campus de Assis, 2002.

Bernardini, Aurora Fornoni. "Aspectos da natureza em Velimir Khlébnikov e Manoel de Barros”. [Cuiabá] Revista Caracol-viola. N zero, pp. 16-27.

Castro, Afonso de. Manoel de Barros: a linguagem e a volta à infância. Campo Grande: Editora da Universidade Católica Dom Bosco, 1992.

Corrêa, Almir Aquino. "O desachamento da finitude em Manoel de Barros". In: Russef, Ivan ; Marinho, Marcelo e Santos, Paulo Sérgio Nolasco dos [organizadores]. Ensaiso farpados: arte e cultura no Pantanal e no Cerrado. 
Campo Grande: UCDB, 2003, p. 21-34.

Costa, Mônica Pinto Rodrigues. "Manoel de Barros - arqueologia da palavra poética". Nova poesia brasileira: 10 poetas. Tese de Doutorado, PUC, 1997, p. 158-1823.

Couto, José Geraldo. "Manoel de Barros busca na ignorância a fonte da poesia". Folha de São Paulo. Livros. 14/11/1993: [6] 8-9.

Cretton, Maria da Graça. "O regional e o literário em Manoel de Barros". In: Cristóvão, Fernando; Ferraz, Maria de Lourdes; Carvalho, Alberto (coordenação). Nacionalismo e regionalismo nas literaturas lusófonas. Lisboa: Edições Cosmos, 1997, p. 161-164.

Fagá, Marcelo. "Nasce um poeta, aos 72 anos". Isto él Senhor, 1015; 1/03/1989: 72-74.

Fraga, Alex. "Manoel de Barros aos olhos da crítica". Revista Nacional, n. 462.

Landeira, José Luis López Landeira. A construção do sentido na poesia de Manoel de Barros: Estudo de elementos expressivos fonéticos e morfossintáticos. (Dissertação de mestrado, FFLCH - USP), 2000.

Magalhães, Magda Martins \& Marinho, Marcelo. "A brasilidade de Manoel de Barros e Guimarães Rosa: do regional ao universal". In: Marinho, Marcelo e colaboradores. Manoel de Barros: o brejo e o solfejo. Brasília: Ministério da Integração social: Universidade Católica Dom Bosco, 2002. (Coleção CentroOeste de Estudos e Pesquisas), p. 59-65.

Marinho, Marcelo. "Cinema e literatura: o Pantanal como metáfora da arte em Joel Pizzini e Manoel de Barros". In: Russef, Ivan ; Marinho, Marcelo e Santos, Paulo Sérgio Nolasco dos [organizadores]. Ensaiso farpados: arte e cultura no Pantanal e no Cerrado. Campo Grande: UCDB, 2003, p. 77-90.

Martins, Waleska \& Marinho, Marcelo. "A obra poética de Manoel de Barros: o processo de criação de neologismos". In: Marinho, Marcelo e colaboradores. Manoel de Barros: o brejo e o solfejo. Brasília: Ministério da Integração social: Universidade Católica Dom Bosco, 2002. (Coleção Centro-Oeste de Estudos e Pesquisas), p. 47-57.

Melotto, Thalita \& Marinho, Marcelo. "Arte, erotismo e repesentação do universo: da pintura rupestre a Manoel de Barros". In: Marinho, Marcelo e colaboradores. Manoel de Barros: o brejo e o solfejo. Brasília: Ministério da Integração social: Universidade Católica Dom Bosco, 2002. (Coleção CentroOeste de Estudos e Pesquisas), p. 15-27. 
Menegazzo, Maria Adélia. "Desvio e humor em Manoel de Barros". Estudos lingüísticos. [São Paulo]. Volume 29, 2000, p. 663-667.

"Manoel de Barrros: o chão é um ensino". Alquimia do verbo e das tintas nas poéticas de vanguarda. Campo Grande - MS: CECITEC/UFMS, 1991.

Pereira, Fábio Mazziotti \& Marinho, Roberto. "Vertentes do niilismo na obra poética de Manoel de Barros". In: Marinho, Marcelo e colaboradores. Manoel de Barros: o brejo e o solfejo. Brasília: Ministério da Integração social: Universidade Católica Dom Bosco, 2002. (Coleção Centro-Oeste de Estudos e Pesquisas), p. 67-88.

Pereira, Julio Neves. Como poetam os poetas? (Uma reflexão interdisciplinar sobre o processo de criação). Dissertação de mestrado. PUC- São Paulo, 1998.

Rainer, Nery Nice Biancalana. A poética de Manoel de Barros e a relação homem-vegetal. [Tese de Doutorado]. FFLCH-USP, 2006.

Ramires, Emanuela Maria Gemignani \& Marinho, Marcelo. “Caramujo-flor, de Joel Pizzini, e a obra poética de Manoel de Barros: perspectivas comparativistas" In: Marinho, Marcelo e colaboradores. Manoel de Barros: o brejo e o solfejo. Brasília: Ministério da Integração social: Universidade Católica Dom Bosco, 2002. (Coleção Centro-Oeste de Estudos e Pesquisas), p. 29-46.

Ramos, Isaac Newton Almeida. Uma poética da modernidade: leitura comparativa entre Alberto Caeiro e Manoel de Barros. Dissertação de Mestrado. USP, 2002.

Ricciardi, Giovanni. "A lesma e o Pau-mulato: dois projetos para uso da natureza". In: Cristóvão, Fernando; Ferraz, Maria de Lourdez; Carvalho, Alberto (coordenação). Nacionalismo e regionalismo nas literaturas lusófonas. Lisboa: Edições Cosmos, 1997, p. 395-398.

Rossoni, Igor. "Manoel de Barros e Guimarães Rosa: o avesso do avesso". In: Russef, Ivan ; Marinho, Marcelo e Santos, Paulo Sérgio Nolasco dos [organizadores]. Ensaios farpados: arte e cultura no Pantanal e no Cerrado. Campo Grande: UCDB, 2003, p. 55-70.

Russef, Ivan \& Ramires, Emanuela Maria Gemignani. "Aspectos semânticos e lexicais da obra poética de Manoel de Barros". In: Russef, Ivan ; Marinho, Marcelo e Santos, Paulo Sérgio Nolasco dos [organizadores]. Ensaios farpados: 
arte e cultura no Pantanal e no Cerrado. Campo Grande: UCDB, 2003, p. 109122.

Santiago, Silviano. "O silêncio, o segredo, Jacques Derrida". In: Nascimento, Evando (org.) Jacques Derrida: pensar a desconstrução. [Tradução de Evando Nascimento et al.]. São Paulo: Estação Liberdade, 2005, p. 125-133.

Silva, Silvana Augusta Barbosa Carrijo. "A poética manoelina: travessuras lexicais". In: Russef, Ivan ;

Marinho, Marcelo e Santos, Paulo Sérgio Nolasco dos [organizadores]. Ensaiso farpados: arte e cultura no Pantanal e no Cerrado. Campo Grande: UCDB, 2003, p. 135-160.

Spironelli, Simone Cristina \& Isquerdo, Aparecida Negri. "O vocabulário de Manoel de Barros". In: Russef, Ivan; Marinho, Marcelo e Santos, Paulo Sérgio Nolasco dos [organizadores]. Ensaiso farpados: arte e cultura no Pantanal e no Cerrado. Campo Grande: UCDB, 2003, p. 179-196.

Uetanabaro, Kati Eliana e Van der Lan, Rita Maria Baltar. "A iconização e a construção ideológica da realidade: o exemplo de Manoel de Barros". [Corumbá] Encontros \& reversos. Ano 1, n. 1, abril de 1995.

Waldman, Berta. "Poesia ao rés do chão". In: Barros, Manoel de. Gramática expositiva do chão: poesia quase toda. Rio de Janeiro: Civilização Brasileira, 1990, pp. 11-32.

\section{OUTROS}

Aguiar, Flávio. "A grande fome do romance brasileiro: os sessenta anos de Macunaíma e os cinqüenta de Vidas secas". Leia, julho de 1988, p. 30-31. 
Ática, 1997.

"Murmúrios no espelho". Machado de Assis: contos. São Paulo:

Alencar, José de. Como e por que sou romancista: autobiografia literária em forma de carta. Porto Alegre: Mercado Aberto, 1998.

Alencar, José de. Iracema. São Paulo: Ática, 1991.

. Iracema. [Edição crítica de M. Cavalcanti Proença, 2a edição]. Rio de Janeiro: Livros Técnicos Científicos; São Paulo: EDUSP, 1979.

. Ubirajara. São Paulo: Ática, 1980.

Andrade, Mário de. "Calar é ouro". Vida literária. [Pesquisa, estabelecimento de texto, introdução e notas por Sonia Sachs. São Paulo: Hucitec; Edusp, 1993, p. 101-106.

- Os contos de Belazarte. [7ª. Edição]. São Paulo e Belo Horizonte: Martins e Ed. Itatiaia, 1980.

. "A língua nacional". Vida literária. [Pesquisa, estabelecimento de texto, introdução e notas por Sonia Sachs. São Paulo: Hucitec; Edusp, 1993, p. 175-178.

. Macunaíma: o herói sem nenhum caráter. [33a. Edição; texto revisto por Telê Porto Ancona Lopez). Belo Horizonte/ Rio de Janeiro: Livraria Garnier, 2004.

. Primeiro andar. In: Obra imatura. [2a. Edição]. São Paulo: Brasília, São Paulo: Martins \& INL, 1972, p. 43-194.

ANTOLOGIA DO CONTO RUSSO: A S PÚCHKIN E N. V. GÓGOL. Vol. 1. (Orientação literária: Vera Newerowa e Otto Maria Carpeaux). Rio de Janeiro: Editora Lux, 1961.

Arrigucci Júnior, Davi. Humildade, paixão, e morte: a poesia de Manuel Bandeira. São Paulo: Companhia das Letras, 1990.

Assis, Machado de. Contos: uma antologia, vol. 2. São Paulo: Cia. das Letras, 
1998.

. Dom Casmurro. [13 a. Edição]. São Paulo: Ática, 1982.

. "D. Paula". Várias histórias. Rio de Janeiro, Belo Horizonte: Livraria Garnier, 1989, p. 125-133.

. "O espelho", in: Papéis avulsos. Obras completas. Vol. 2. Rio de Janeiro: Editora Nova Aguilar, 1992, p. 349-350.

Memórias póstumas de Brás Cubas. [10a. Edição]. São Paulo: Ática, 1984, p. 132.

. "Só!", in: Obras completas. Vol. 2. Rio de Janeiro: Editora Nova Aguilar, 1992, p. 1044-1050.

Bacalarski, M. C. Algumas funções do silêncio na comunicação humana. S.P.: USP, 1991, Dissertação de mestrado.

Bakhtin, M. "Rabelais e Gógol (arte do discurso e cultura cômica popular)". Questões de literatura e estética. 5a ed., São Paulo: Hucitec \& Annablume, 2002.

Balbuena, Monique. Poe e Rosa à luz da cabala. Rio de Janeiro: Imago, 1994.

Barbosa, João Alexandre. "Leitura, ensino e crítica da literatura". A biblioteca imaginária. São Paulo: Ateliê Editorial.

Barreto, Lima. Contos Reunidos. [Org. de Oséias Silas Ferraz]. Belo Horizonte: Crisálida, 2005.

Beckett, Samuel. Carta Alemã. [Tradução de Fábio de Souza Andrade]. In: Andrade, Fábio de Souza. Samuel Beckett: o silêncio possível. São Paulo: Ateliê, 2001, p. 167-171.

2003.

. Como é. [Tradução Ana Helena de Souza]. São Paulo: Iluminuras,

. O inominável. (trad. de Waltensir Dutra). Rio de Janeiro: Nova 
Fronteira, 1989.

- Poemas. [Seleção, tradução e apresentação de Luiz Roberto Benati]. São Paulo: Editora Olavobrás, 1987.

Behar, Lisa Block. "Reticencias del texto". Una retórica del silencio: funciones del lector y procedimentos de la lectura literaria. Mexico: Siglo Veintiuno Editores, , 1984: 235-244

Belinky, Tatiana. "Introdução". In: Tchekhov, Anton. Homem no estojo. [Tradução de Tatiana Belinky]. São Paulo: Global Editora, 1986.

Benjamin, Walter. "O narrador". Magia e técnica, arte e política. Obras escolhidas. Vol. 1 [Tradução de Sérgio Paulo Rouanet; pref. de Jeanne Marie Gagnebin]. SP: Brasiliense, 1994, p. 197-221.

Bezerra, Paulo. "Polifonia". In: Brait, Beth. [org.]. Bakhtin: conceitos-chave. São Paulo: Contexto, 2005, p.101-200.

Bianchi, Maria de Fatima. Os caminhos da razão e as tramas secretas do coração: a representação da realidade em A dócil, de Dostoiévski. [Dissertação de Mestrado, FFLCH, Departamento de Teoria Literária e Literatura Comparada], 2001.

Bloom, Harold. Um mapa da desleitura [ tradução de Thelma Médici Nóbrega]. Rio de Janeiro: Imago: 1995.

Buarque, Chico. Estorvo. [Quarta reimpressão]. São Paulo: Companhia das Letras, 1991.

Buñuel, Luis. Meu último suspiro. [Tradução de Rita Braga, 2ª. Edição]. Rio de Janeiro: Nova Fronteira, 1982.

Burke, Peter. "Escutar o silêncio". Folha de São Paulo. 19 de setembro de 1999, (Mais! 5). p. 4-5.

Campos, Haroldo. "Iracema: uma arqueografia de Vanguarda". Metalinguagem \& outras metas. São Paulo: Perspectiva, 1992, p.127-145.

Carone, Modesto. A poética do silêncio. São Paulo: Perspectiva, 1979. 
Cassirer, Ernst. Linguagem e mito. [Trad. de J. Guinsburg e Miriam Schnaiderman]. São Paulo: Editora Perspectiva, 1972.

Cavaliere, Arlete. "A magia das máscaras". In: Nikolai Gógol. O nariz \& A terrível vingança. São Paulo: Edusp, 1990.

. "N. V. Gógol: uma visão cultural". Revista da Biblioteca Mário de Andrade v. 59. [São Paulo], Janeiro/Dezembro de 2001, pp. 139-143.

Chalhoub, Sidney. Machado de Assis, historiador. São Paulo: Cia. das Letras, 2003.

Chaves, Ernani. “O 'silêncio trágico': Walter Benjamin entre Franz Rosenzweig e Friedrich Nietzche". Seligmann-Silva, Márcio (org.). Leituras de Walter Benjamin. São Paulo: Annablume, Fapesp, 1999, p.113-125.

Cortázar, Julio. "Alguns aspectos do conto". Valise de cronópio. [tradução de Davi Arrigucci Jr. E João Alexandre Barbosa]. São Paulo: Perspectiva, 2004.

Derrida, Jacques. O animal que logo sou. [Trad. de Fábio Landa]. São Paulo: Editora da UNESP, 2002.

Dinouart, Josep Antoine Toussaint. A arte de calar. [Tradução de Luis Felipe; texto apresentado por Jean-Jacques Courtine e Claudine Harouche]. São Paulo: Martins Fontes, 2001. (Breves encontros)

Dostoiévski, Fiódor. "Bobok". In: Bezerra, Paulo. Dostoiévski: "Bobók", tradução e análise do conto. São Paulo: Editora 34, 2005, p. 13-38.

Drummond de Andrade, Carlos. Antologia poética. [4a. Edição]. Rio de Janeiro: Editora do Autor, 1966.

Eliot, T. S. "Tradição e talento individual". Ensaios. (Trad. de Ivan Junqueira). São Paulo: Art Editora, 1989, pp. 37-48. 
. Poesias. [Tradução, introdução e notas de Ivan Junqueira]. Rio de Janeiro: Nova Fronteira, 1981.

Fabris, Mariarosaria. "Apresentando Roberto Rosselini". Roberto Rosselini: do cinema e da televisão. São Paulo, S. D. , p. 6-9.

. "Federico Fellini: quase um auto-retrato". Caderno 2/Cultura. $O$ Estado de São Paulo. [São Paulo]. 10 de outubro de 2004, p. 6.

. "Fontes pictóricas de Senso". Esplendor de Visconti. (Catálogo de retrospectiva cinematográfica). São Paulo, agosto de 2002, p. 32-33.

Fogel, Gilvan. "A respeito do fazer necessário e inútil Ou do silêncio". In: Schuback, Márcia Sá Cavalcante et alii. Por uma fenomenologia do silêncio. Rio de Janeiro: Livraria Sette Letras, 1996.

Ganguly. "Culture communication and silence". Philosophy and phenomenological research.

Gumbrecht, Hans Ulrich. "Silêncio versus barulho". Em 1926: vivendo no limite do tempo. Rio de Janeiro: Record, 1999.

Fabris, Mariarosaria. "Federico Fellini: quase um auto-retrato". Caderno2/Cultura. O Estado de São Paulo. 10 de outubro de 2004, p. 6.

. "Fontes pictóricas de 'Senso'”. Luchino Visconti. [catálogo da mostra cinematográfica]. São Paulo. 2002.

Fellini, Federico. Entrevista sobre o cinema. [Realizada por Giovanni Grazzini; traduçao de José Alberto de Lima Campos. Rio de Janeiro: Civilização Brasileira, 1986.

Frenk, Margit. Entre la voz y el silencio: la lectura en tiempos de Cervantes. Mexico: FCE, 2005.

Friedrich, Hugo. Estrutura da lírica moderna: da metade do século XIX a meados do século XX. São Paulo: Duas Cidades, 1978.

Frye, Northrop. "A literatura como contexto: Lycidas de Milton". Fábulas de 
identidade. [Tradução de Sandra G. T. Vasconcelos].

. T. S. Eliot. [Trad. de Elide-Lela Valarine]. Rio de Janeiro: Imago, 1998.

Anatomia da crítica. [Tradução de Péricles Eugênio da Silva Ramos]. São Paulo: Cultrix, 1973.

Garcia Lorca, Federico. "O silêncio". Obra poética completa. [apresentação Ático Vilas-Boas da Mota; trad. William Agel de Mello; 3a. Edição] São Paulo: Martins Fontes, 1999, p. 185.

Goethe, J. W. Doutrina das cores. [Apresentação, seleção e tradução de Marco Giannotti]. São Paulo: Nova Alexandria, 1993.

Gógol, Nikolai. “A avenida Niévski” [tradução de Arlete Cavaliere], São Paulo: Paz e Terra, 2002 [Coleção Leitura].

. O capote e outras novelas de Gógol. [Seleção, tradução prefácio e notas de Paulo Bezerra]. Rio de Janeiro: Editora Civilização Brasileira, 1990.

. O nariz \& A terrível vingança. [Tradução de Arlete Cavaliere]. São Paulo: EDUSP, 1990.

. O capote, seguido de O retrato. [ Tradução de Roberto Gomes]. Porto Alegre: L \& PM, 2000.

Grieco, Agrippino "Sobre o autor de Almas mortas", in: Gogol, N. Almas mortas: aventura de

Chichikov. Rio de Janeiro, Cia. Brasil Editora, 1937, 6.

Holanda, Lourival. Sob o signo do silêncio. São Paulo: Editora da Unvivesidade de São Paulo, 1992.

Iannace, Ricardo. "A insuportável contenção: Clarice Lispector e Katherine Mansfield". Magma, n. 3, 1996. São Paulo. 2001.

. A leitora Clarice Lispector. São Paulo: Editora da Universidade de 
- Retratos em Clarice Lispector: literatura, pintura e fotografia. [Tese de Doutorado]. São Paulo, FFLCH-USP, 2004.

INTERTEXTUALIDADES. Coimbra: Almedina, 1979.

Janson, H. W. \& Janson, Anthony F. “Klee”. Iniciação à História da arte. 2a. ed. São Paulo: Martins Fontes. 1996, p. 377-378.

Joyce, James. O retrato do artista quando jovem. [Tradução de José Geraldo Vieira]. Rio de Janeiro: Abril Cultural, 1971.

1983.

. Ulisses. [Tradução de Antonio Houaiss]. São Paulo: Abril Cultural,

Kahn, Daniela. A via-crucis do outro: identidade e alteridade em Clarice Lispector. São Paulo: Humanitas, 2005.

. "Baratas literárias ou A humilde epifania do 'homem-inseto' ". Trabalho de fim de curso do Professor Convidado Pierre Rivas (Paris X), para disciplina "Metodologia da Literatura Comparada", oferecida pelo Departamento de Teoria Literária e Literatura Comparada, na Universidade de São Paulo, 1994.

Kierkegaard, Soren. "Pode moralmente justificar-se o silêncio de Abraão perante Sara, Eliezer e Isaac?". In: Temor e tremor. Rio de Janeiro, Ediouro, s.d., p. 91-120.

Kikuchi, Tereza (org.). José Mindlin, editor. São Paulo: Editora da Universidade de São Paulo, 2004.

Kovadloff, Santiago. "O silêncio da luz: a pintura". O silncio primordial: ensaios. [Tradução de Eric Nepomuceno e Luís Carlos Cabral. Rio de Janeiro: José Olympio, 2003

Labastida, Jaime. Animal de silêncios. Antologia poética [Tradução de Hermenegildo José Bastos]. São Paulo: Ateliê Editorial, 2002.

Lafetá, João Luiz. "Mário de Andrade, o arlequim estudioso". A dimensão da noite. São Paulo: Duas Cidades, Editora 34, 2004, p. 213-225.

Lima, Alceu Amoroso. Meditação sobre o mundo interior. Rio de Janeiro: Livraria Agir Ltda., 1954.

Lisboa, Luiz Carlos. "O que é sem nome". O nome das coisas. São Paulo: Summus, 1980. 
Lispector, Clarice. O lustre. Rio de Janeiro: Rocco,1999.

London, Jack. "O silêncio branco". Histórias de Jack London. [Seleção, tradução e prefácio de Olívia Krãhenbühl]. São Paulo: Cultrix, 1984, p. 15-25.

Lopez, Telê Ancona. "Prefácio... também crônica". In: Camara, Cristiane Yamada. Mário na Lopes Chaves. São Paulo: Memorial, 1996, p. 7-11.

Mansfield, Katherine. Cinco contos. São Paulo \& Rio de Janeiro: Paz e Terra S.A., 1997.

. Diário, 17 de janeiro de 1921. In: Mansfield, K. Contos. [Trad. de

Carlos

Eugênio Marcondes de Moura e Alexandre Barbosa de Souza]. São Paulo: Cosac Naify, 2005, p. 272.

Meireles, Cecília. "Houve um poema...". Poesia completa, vol. II, [org. de Antonio Carlos Secchub.]. Rio de Janeiro: Editora Nova Fronteira, 2001, p. 1249-1250.

Meletínski, E. M. Os arquétipos literários. (2a ed., tradução de Aurora Fornoni Bernardini, Homero Freitas de Andrade e Arlete Cavaliere). São Paulo: Ateliê Editorial, 2002.

. A poética do mito. (Tradução de Paulo Bezerra). Rio de Janeiro: Forense-Universitária, 1987.

Meneses, Adélia Bezerra de. "As canções de repressão". Desenho mágico: poesia e política em Chico Buarque. São Paulo: Hucitec, 1982, p. 98-103.

Meyer, Augusto. "O homem do subterrâneo". In: Machado de Assis (2 ${ }^{a}$. Edição). Rio de Janeiro: Edição da Organização Simões, 1952, p. 19).

Nef, Frédéric. A linguagem: uma abordagem filosófica. [Tradução de Lucy Magalhães]. Rio de Janeiro: Jorge Zahar, 1995.

Nunes, Benedito. "Hölderlin e a essência da poesia". Hermenêutica e poesia: o pensamento poético. [Org. de Maria José Campos]. Belo Horizonte: Ed. UFMG, 1999, p. 119-127. 
Orlandi, Eni Puccinelli. As formas do silêncio: no movimento dos sentidos. Campinas: Editora da UNICAMP, 1993.

Perrone-Moisés, Leyla. "Intertextualidade, Literatura Comparada e Antropofagia". Flores da escrivaninha: ensaios. São Paulo: Cia. das Letras, 1990, p. 91-99.

Plutarco. Como ouvir. [Prefácio e notas de Pierre Maréchaux; tradução (grego e francês) de João Carlos Cabral Mendonça; revisão da tradução de Henrique F. Cairus e Tatiana Ribeiro]. São Paulo: 2003.

Poe, Edgar Allan. "A filosofia da composição". "O corvo" e suas traduções. [2a. ed. revista e ampliada] [org. de Ivo Barroso]. Rio de Janeiro: Lacerda Ed., 2000.

. "Silêncio (Fábula)". Ficção completa, poesia \& ensaios. [Quarta reimpressão]. Rio de Janeiro: Editora Nova Aguilar S. A, 2001, p. 385-387.

. "Silêncio". Ficção completa, poesia \& ensaios. [Quarta reimpressão]. Rio de Janeiro: Editora Nova Aguilar S. A, 2001, p. 955.

Pontieri, Regina. Clarice Lispector: uma poética do olhar. São Paulo: Ateliê Cultural, 1999.

Propp, Vladimir. Comicidade e riso. [Tradução de Aurora F. Bernardini e Homero F. de Andrade]. São Paulo: Ática, 1992

Proust, Marcel. Sobre a leitura. [Trad. de Carlos Vogt]. Campinas: Pontes, $2^{\underline{a}}$ edição, 1991.

Pseudo-Denys L'Aréopagite. La teologie mystique. In: Òeuvres complètes du Pseudo-Denys L'Aréopagite. Paris: Aubier Editions Montaigne, 1943, pp. 177184.

Puls, Maurício. O significado da pintura abstrata. São Paulo: Perspectiva, 1998.

Rimbaud, Arthur. "Infância". Iluminuras: gravuras coloridas. [Tradução, notas e ensaio de Rodrigo Garcia Lopes e Maurício Arruda Mendonça; edição belingüe]. São Paulo: Iluminuras, 1994, p. 11-15. 
Rivera, Tania. “ 'A menina de lá' e o desejo do psicanalista' ".Guimarães Rosa e a pisicanálise: ensaios sobre imagem e escrita. Rio de Janeiro: Jorge Zahar Editor, 2005.

Rocha, Glauber. "O barroco viscontiano". Esplendor de Visconti. (Catálogo de retrospectiva cinematográfica). São Paulo, agosto de 2002, p. 30-31.

Rosa, Agnes Guimarães. "Lembrança do "João Papai Beleza". Revista do livro.[São Paulo] n. 45, ano 14, outubro de 2002, p. 7-18.

Rosa, João Guimarães. Primeiras estórias. [44a. Edição]. Rio de Janeiro: Nova Fronteira, 1988. . “Uns índios (sua fala)”. Ave, palavra. [5a. Edição; notas de Paulo Rónai]. Rio de Janeiro: Nova Fronteira, 2001, p. 125-128.

Ruin, Hans. "O silêncio da filosofia: sobre discurso e taciturnidade em Heidegger". In: Schuback, Márcia Sá Cavalcante et alii. Por uma fenomenologia do silêncio. Rio de Janeiro: Livraria Sette Letras, 1996.

Saer, José Juan. In: Folha de São Paulo, 19 de setembro de 1999, mais! 5-5.

Salles Gomes, Paulo Emílio. "Infidelidades de Visconti". Esplendor de Visconti. (Catálogo de retrospectiva cinematográfica). São Paulo, agosto de 2002, p. 2729.

Santiago, Silviano. "Iracema, o coração indômito de Pindorama". In: Mota, Lourenço Dantas \& Abdala Junior, Benjamin. Personae: grandes personagens da literatura brasileira. São Paulo: Editora SENAC, 2001. 13-33.

Sartre, Jean-Paul. A náusea. [Tradução de Rita Braga]. Rio de Janeiro: Nova Fronteira, 2006.

Saverdini, Erika. Índices de um cinema de poesia: Pier Paolo Pasolini, Luis Buñuel e Krzysztof Kieslowski. Belo Horizonte: Editora de UFMG, 2004.

Schnaiderman, Boris. "' 'O alienista', um conto dostoievskiano?”. Teresa, revista de Literatura Brasileira [6/7]; São Paulo, 2006, p. 268-273,.

Sciacca, Michele Federico. Silêncio e palavra. Rio Grande do Sul, 1966.

Senna, Marta de. "Machado de Assis e Tchekhov: conto de memória". Olhar oblíquo do bruxo: ensaios em torno de Machado de Assis. Rio de Janeiro: Ediotra Nova Fronteira, 1998, p. 105-110.

Silveira, Julio e Ribas, Martha (organizadores). A paixão pelos livros. Rio de Janeiro: Casa da Palavra, 2004. 
Simons, Marisa. As falas do silêncio em $O$ fiel e a pedra de Osman Lins. São Paulo: Humanitas, 1999.

Sousa, Cruz e. Obras completas. Rio de Janeiro: Nova Aguillar, 2000.

Souza, Gilda de Mello e \& Candido, Antonio. "Os deuses malditos". Esplendor de Visconti. (Catálogo de retrospectiva cinematográfica). São Paulo, agosto de 2002, p. $22-26$

Steiner, George. "O poeta e o silêncio". Linguagem e silêncio: ensaios sobre a crise da palavra. (Tradução de Gilda Stuart e Filipe Rajabally). São Paulo: Cia. das Letras, 1988.

. "O repúdio à palavra". Linguagem e silêncio: ensaios sobre a crise da palavra. (Tradução de Gilda Stuart e Filipe Rajabally). São Paulo: Cia. das Letras, 1988.

Tarricone, Jucimara. A escritura silenciosa de Caeiro e Artaud. (Dissertação de mestrado defendida na PUC-SP), 1997.

Tchékhov, Anton. A dama do cachorrinho e outros contos. [Trad. de Boris Schnaiderman. 4a edição]. São Paulo: Editora 34, 1999.

2004. . A gaivota. [Trad. de Rubens Figueiredo]. São Paulo: Cosac Naify,

"The butterfly". Seven Stories. [Translated by Ronald Hingley]. Oxford: Oxford University Press, 1974, p. 1-22.

Teles, Gilberto Mendonça. "Introdução". Retórica do silêncio: teoria e prática do texto literário. Rio de Janeiro: José Olympio, 1989.

Thomas, Dylan. Retrato do artista quando jovem cão. [Tradução de Alfredo Margarido]. Lisboa: Edição "Livros do Brasil", 1961.

Vássina, Elena. "O eterno Tchekov". In: As três irmãs. [Trad. de Klara Gouriánova]. São Paulo: Peixoto Neto, 2004, p. 11-22.

Ward, Terezinha Souto. O discurso oral em Grande sertão: veredas. São Paulo: Duas Cidades; Brasília: INL, Fundação Nacional Pró-Memória, 1984. 


\section{FILMOGRAFIA}

\section{DE AKIRA KUROSAWA}

"O anjo embriagado". VHS, S.D.

"O barba ruiva". [1965]. DVD, Continental, S. D.

“Cão danado". [1949]. DVD, Media Group, S. D.

"Céu e inferno" [1963]. DVD, Continental, S. D.

“Dodes'ka-den" [1970]. DVD, Continental, S. D.

“Dersu Uzala” [1974]. DVD, Continental, S. D.

"A fortaleza escondida". [1958]. DVD, Continental, S. D.

“O idiota”. [1951]. VHS. S. D.

"Kagemusha, a sombra do samurai" [1980]. DVD, Continental, S. D.

“Madadayo" [1992]. DVD, Continental, S. D.

"Ralé" [1957]. DVD, Continental, S. D.

"Ran". [1985]. DVD, Van Blad, S. D.

"Rashomon" [1950]. DVD, Continental, S. D.

"Sanjuro" [1962]. DVD, Continental, S. D.

"Os 7 samurais" [1970]. DVD, Continental, S. D.

"Sonhos" [1990]. DVD, Warner Brothers, S. D.

"Trono manchado de sangue". [1857]. DVD, Continental, S. D.

"Viver" [1952]. DVD, Media Group, S. D.

"Yojimbo" [1961]. DVD, Continental, S. D. 


\section{DE FEDERICO FELLINI}

"Abismo de um sonho". [1952]. DVD, Versátil, 2004.

"Agência matrimonial”. [1953]. DVD, Versátil, 2005.

"Amarcord". [1973]. DVD, Continental, S. D.

“Os boas-vidas". VHS, S. D.

"Cidade das mulheres". [1980]. Versátil, S. D.

"I clowns". [1971]. VHS, S. D.

"A doce vida". [1959]. DVD, Versátil, 2002.

“E la nave va”. [1983]. DVD, Versátil, 2004.

"Ensaio de orquestra". [1979]. DVD, Versátil, S. D.

"Entrevista". [1987]. VHS, Look Vídeo, S. D.

“Ginger e Fred”. [1986]. DVD, Versátil, 2002.

“Julieta dos espíritos”. [1965]. DVD, Versátil, 2003.

“Mulheres e luzes". [1950]. DVD, Versátil, S. D.

"Noites de Cabíria" [1957]. VHS, S. D.

"Oito e meio". [1962]. VHS, S. D.

“Roma”. [1972]. VHS, S. D.

“La strada” [1954]. DVD, Versátil, 2003.

"Satyricon [1969]. VHS, S. D.

"As tentações do Dr. Antonio", in: "Boccaccio '70". [1962], DVD, Versátil, S. D. “Toby Dammit". [ 1969]. In: "Histórias extraordinárias". DVD, Cinemagia, S. D. "A trapaça". [1955]. DVD, Versátil, 2004.

“A voz da lua”. [1989]. VHS, Look Vídeo, S. D. 


\section{DE LUIS BUÑUEL}

“O alucinado". [1953]. DVD, Versátil, 2004.

“O anjo exterminador”. [1962]. DVD, Versátil, 2003.

"A bela da tarde". [1967]. VHS, S. D.

"O diário de uma camareira". [1964]. DVD, Cult \& Classics, S. D.

"O discreto charme da burguesia". DVD.

"Ensaio de um crime”. [1954]. DVD, Versátil, 2004.

"Escravos do rancor". [1953]. DVD, Versátil, 2004.

"Os esquecidos". [1950]. DVD, Seleções DVD, S. D.

"Esse obscuro objeto do desejo". [1977]. VHS, Sagres, S. D.

"O fantasma da liberdade”. [1974]. DVD, Silver Screen Collection. S. D.

"A ilusão viaja de trem". [1953]. DVD, Versátil, S. D.

“Nazarin". [1958]. DVD, Cult \& Classics, S. D.

"Robinson Crusoé". [1952]. DVD, Versátil, S. D.

"Simão no deserto". [1965]. VHS [Vídeo gravado a partir de um canal televisivo, disponível na ECA - USP], S. D.

"Subida ao céu". [1951]. DVD, Cult \& Classics, S. D.

“Terra sem pão" [1932]. [Extra do DVD “Os esquecidos”]. Seleções DVD, 2004.

“Tristana”. [1970]. VHS, F. J. Lucas Vídeo, S. D.

“Um cão andaluz"/ "A idade do ouro" . [1928/ 1930]. DVD, Versátil, S. D. 